\title{
Holocene Cyclicity in Western North Dakota - Climate Change Interpreted from Fluctuations in Alluvial Sedimentation
}

\author{
Final Report \\ for the period \\ January 16, 1996, to December 31, 1997 \\ by \\ Joseph H. Hartman \\ Energy \& Environmental Research Center \\ University of North Dakota \\ 15 North 23rd Street \\ Grand Forks, ND 58203 \\ with \\ Deborah L. Beck \\ Department of Geology and Geological Engineering \\ University of North Dakota \\ PO Box 8358 \\ Grand Forks, ND 58202 \\ David D. Kuehn \\ Department of Anthropology \\ Texas A\&M University \\ College Station, TX 77843 \\ John R. Reid \\ Department of Geology and Geological Engineering \\ University of North Dakota \\ PO Box 8358 \\ Grand Forks, ND 58202 \\ Jon Reiten \\ Montana Bureau of Mines and Geology \\ Montana State University \\ 1500 North 30th \\ JBillingơsh 59101 \\ 의 $\forall$ bl 7 in bbbl' \\ EPRI Agreement W08035-06

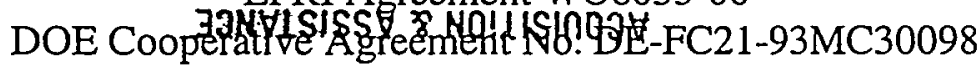




\section{DISCLAIMER}

This report was prepared as an account of work sponsored by an agency of the United States Government. Neither the United States Government nor any agency thereof, nor any of their employees, make any warranty, express or implied, or assumes any legal liability or responsibility for the accuracy, completeness, or usefulness of any information, apparatus, product, or process disclosed, or represents that its use would not infringe privately owned rights. Reference herein to any specific commercial product, process, or service by trade name, trademark, manufacturer, or otherwise does not necessarily constitute or imply its endorsement, recommendation, or favoring by the United States Government or any agency thereof. The views and opinions of authors expressed herein do not necessarily state or reflect those of the United States Government or any agency thereof. 


\section{DISCLAIMER}

Portions of this document may be illegible in electronic image products. Images are produced from the best available original document. 


\section{TABLE OF CONTENTS}

LIST OF TABLES $\ldots \ldots \ldots \ldots \ldots \ldots \ldots \ldots \ldots \ldots \ldots \ldots \ldots \ldots \ldots \ldots \ldots \ldots \ldots \ldots \ldots$

EXECUTIVE SUMMARY $\ldots \ldots \ldots \ldots \ldots \ldots \ldots \ldots \ldots \ldots \ldots \ldots \ldots \ldots \ldots$

Originally Proposed Significance $\ldots \ldots \ldots \ldots \ldots \ldots \ldots \ldots \ldots \ldots \ldots \ldots \ldots$

Basic Climate/Paleosol Premise . . . . . . . . . . . . . . . . . . . v

Short-Term Cyclicity $\ldots \ldots \ldots \ldots \ldots \ldots \ldots \ldots \ldots \ldots \ldots \ldots \ldots \ldots \ldots$

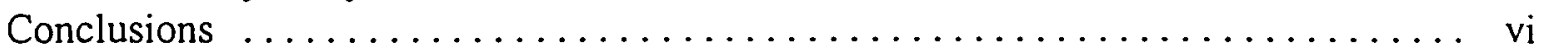

Publications $\ldots \ldots \ldots \ldots \ldots \ldots \ldots \ldots \ldots \ldots \ldots \ldots \ldots \ldots \ldots$ viii

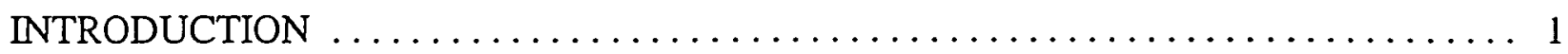

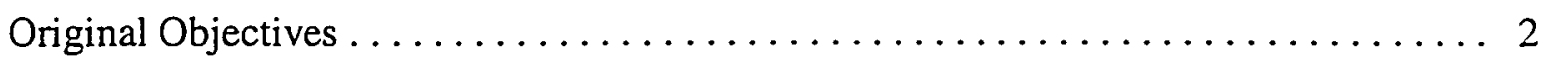

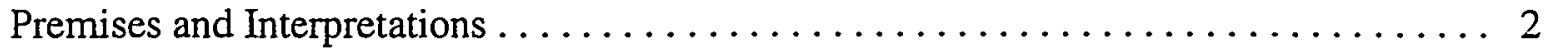

Basic Hypothesis Regarding Soil, Climate, and Geomorphic Relationships . . . . 2

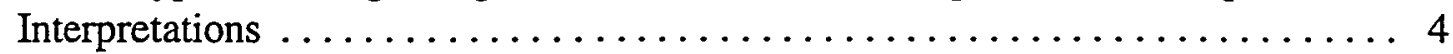

Reflections and Future Studies $\ldots \ldots \ldots \ldots \ldots \ldots \ldots \ldots \ldots \ldots \ldots \ldots \ldots$

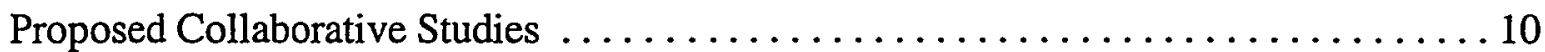

Abbreviations/Terminology $\ldots \ldots \ldots \ldots \ldots \ldots \ldots \ldots \ldots \ldots \ldots \ldots \ldots \ldots$

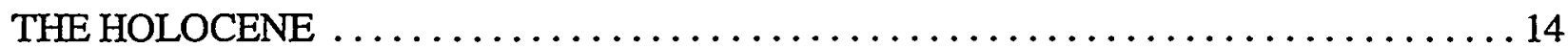

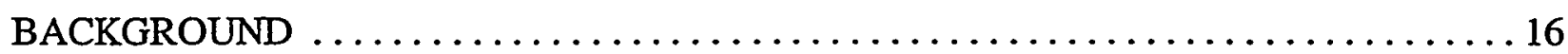

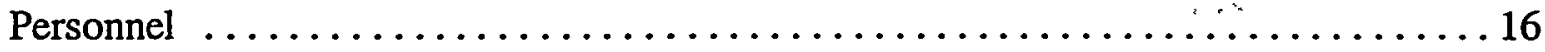

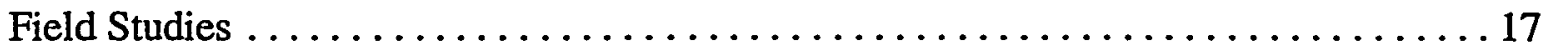

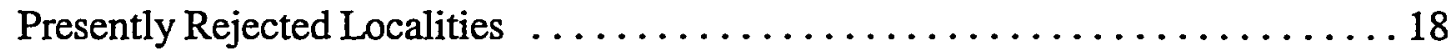

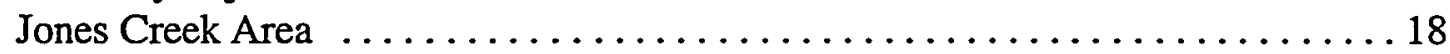

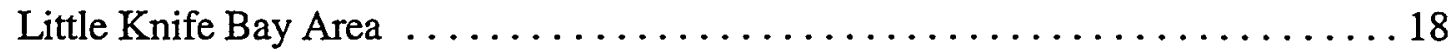

Study Localities . . . . . . . . . . . . . . . . . . . . . . . . . . 19

Knutson Creek (Localities D and M) and Fryburg (Locality C) Areas . . . . . . . . 19

Knife River Indian Villages Area (Elbee Bluff Locality) . . . . . . . . . . . 19

Emmet Area (Douglas Creek Locality) . . . . . . . . . . . . . . . . . 20

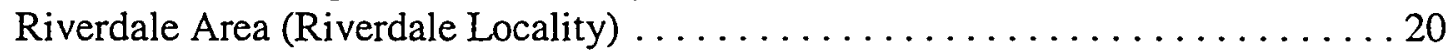

Meetings . . . . . . . . . . . . . . . . . . . . 20

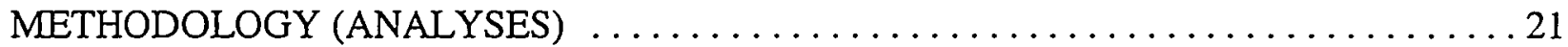

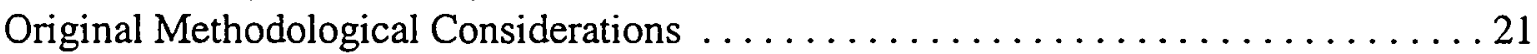

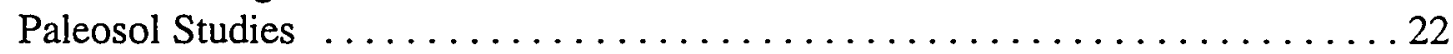

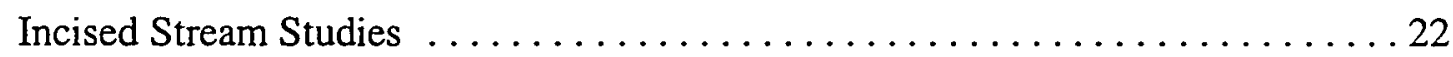

Alluvial Fan Studies . . . . . . . . . . . . . . . . . . . . 23

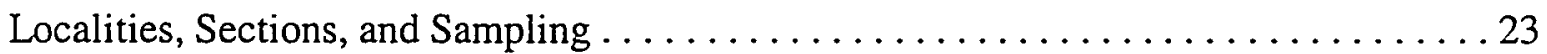

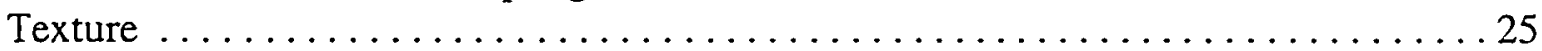

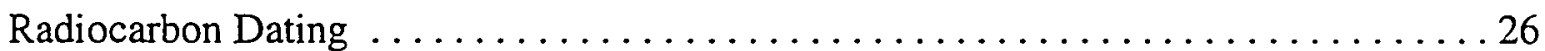

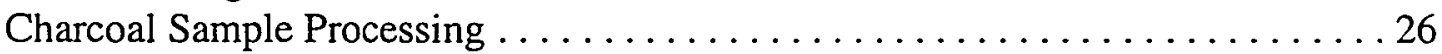




\section{TABLE OF CONTENTS (continued)}

Charcoal Versus Lignite ................................. 27

Radiocarbon Dating of Charcoal ............................ 28

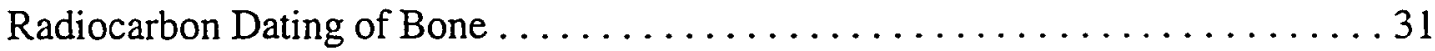

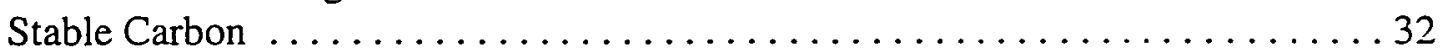

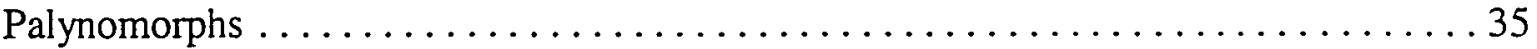

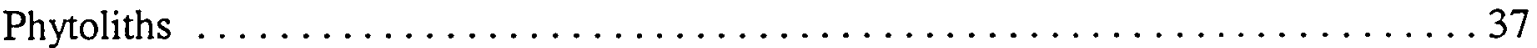

Mollusks ......................................... 40

Paleosol Ages at the Douglas Creek Locality ...................... 40

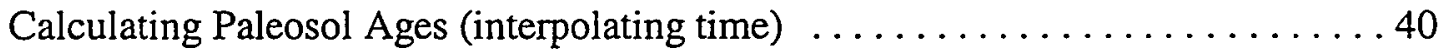

Recurrence ..................................... 44

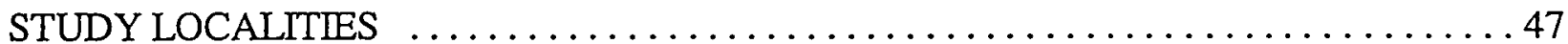

Knutson Creek - Locality D . . . . . . . . . . . . . . . . . . . . . . . . . 48

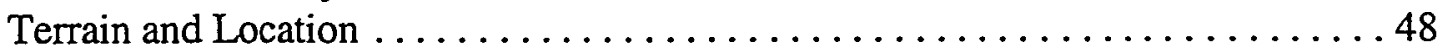

Modern Soil ...................................... 49

Geologic Section M8297 ...............................49

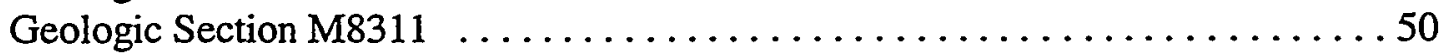

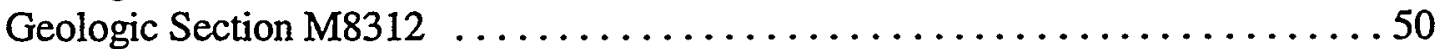

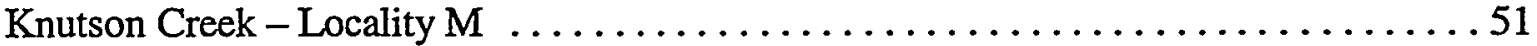

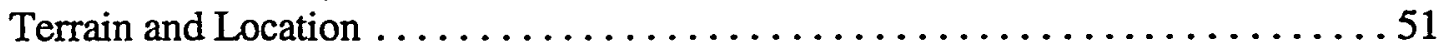

Modern Soil ........................................ 51

Geologic Section M8298 ................................ 51

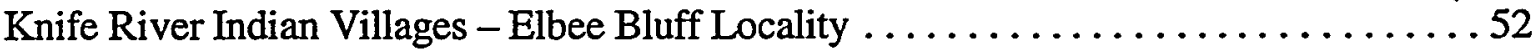

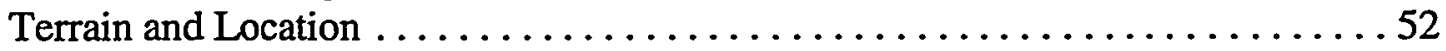

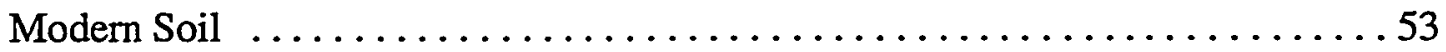

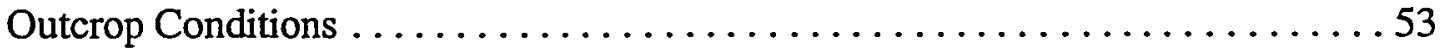

Geologic Section M8299 ................................ 53

Reiten's Terrace Framework ............................. 55

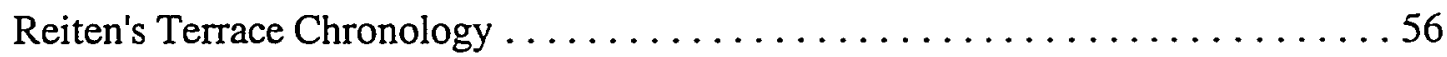

Douglas Creek Locality ....................................... 57

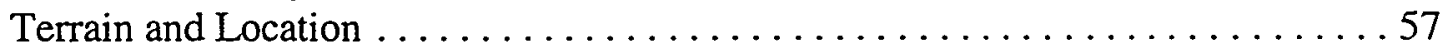

Modern Soil .......................................... 57

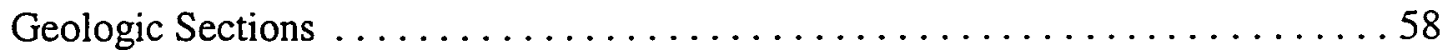

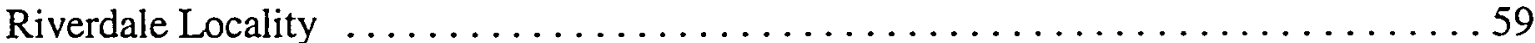

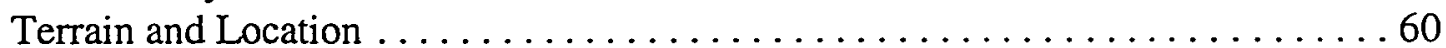

Modern Soil ........................................60 60

Geologic Section M8300 ................................ 60

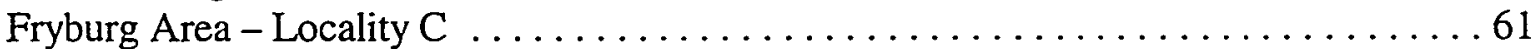

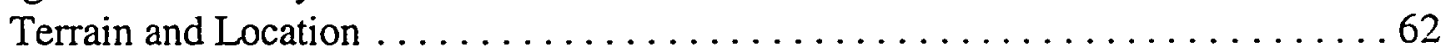

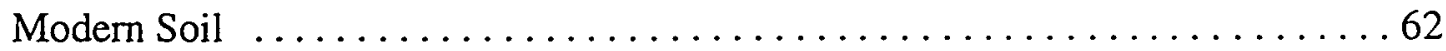

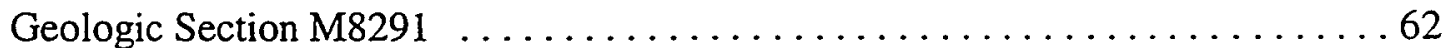

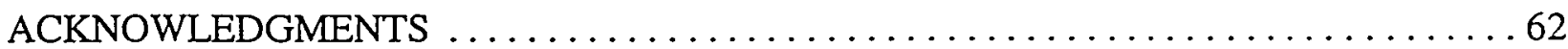




\section{TABLE OF CONTENTS (continued)}

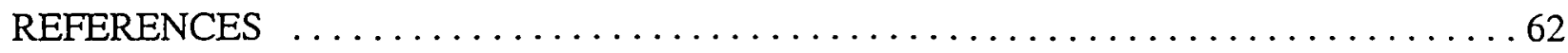

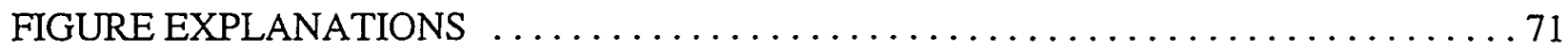

THEODORE ROOSEVELT NATIONAL PARK

RESEARCH ACTIVITY PERMIT $\ldots \ldots \ldots \ldots \ldots \ldots \ldots \ldots \ldots$ Appendix A

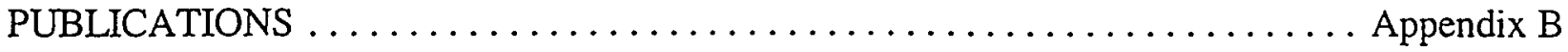




\section{LIST OF TABLES}

1 Locality, Section, and Sampling Nomenclature $\ldots \ldots \ldots \ldots \ldots \ldots \ldots \ldots \ldots \ldots$

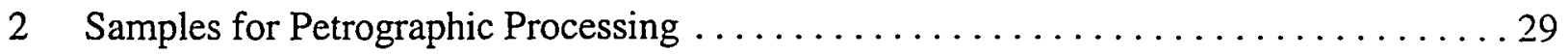

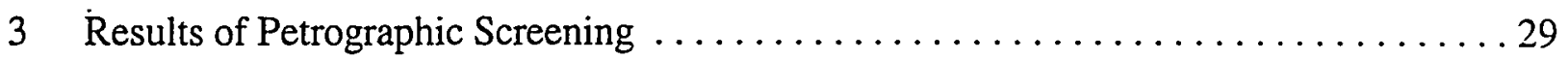

4 Radiocarbon and Stable Carbon Values for Project Localities .................. 33

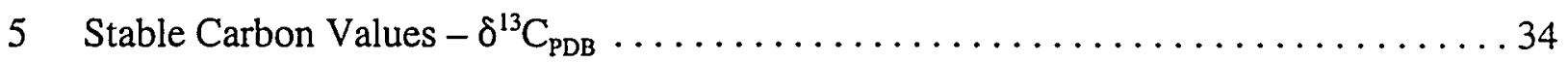

6 Palynomorph Annotations for Project Localities ....................... 37

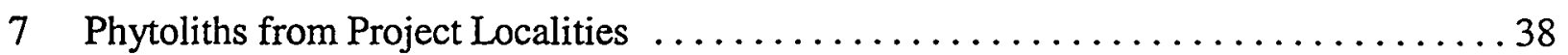

8 Pulmonate Mollusks from Project Localities $\ldots \ldots \ldots \ldots \ldots \ldots \ldots \ldots \ldots \ldots \ldots \ldots$

9 Molluscan Specimen Documentation $\ldots \ldots \ldots \ldots \ldots \ldots \ldots \ldots \ldots \ldots \ldots \ldots \ldots \ldots \ldots \ldots \ldots \ldots$

10 Pulmonate Age and Modern Ecology $\ldots \ldots \ldots \ldots \ldots \ldots \ldots \ldots \ldots \ldots \ldots \ldots \ldots \ldots \ldots \ldots \ldots$

11 Interpolating the Age of Paleosols in Section M8302 $\ldots \ldots \ldots \ldots \ldots \ldots \ldots$

.12 Interpolating the Age of Paleosols in Section M8303 $\ldots \ldots \ldots \ldots \ldots \ldots$ 


\section{HOLOCENE CYCLICITY IN WESTERN NORTH DAKOTA - CLIMATE CHANGE INTERPRETED FROM FLUCTUATIONS IN ALLUVIAL SEDIMENTATION}

\section{EXECUTIVE SUMMARY}

\section{Originally Proposed Significance}

This project undertook a close examination of the relationship between Holocene alluvial sedimentation and climatic variation. Although various techniques have been employed to interpret climate during postglacial times, the few studies in semiarid badlands terrains have focused on a general understanding of the broadscale climatic history. This project interpreted finer sedimentary patterns to recognize and interpret climatic variations that may occur as shortperiod cycles. Such interpretations provide a new approach to examining climatic variability in the past, reflecting periods of extended dry and moist conditions, and will result in the development of a more rigorous basis for interpreting human interactions with both their physical and biotic surroundings.

\section{Basic Climate/Paleosol Premise}

Key or basic underlying premises to this study are discussed in the main body of this report. The following premise and illustration (Figure ES-1A) provide the background for the Executive Summary. During periods when landforms (landscapes) are stable, hillslopes are covered by a protective mat of vegetation and a balance is established between weathering (soil formation) and valley sedimentation. The weathering of surface sediments during periods of landscape stability produces soils. During periods of landscape instability, vegetation is significantly reduced, if not removed completely, particularly in semiarid regions such as western North Dakota. This leads to slope disequilibrium as erosion outpaces soil formation (Figure ES-1B). Disequilibrium results in the total and/or partial truncation of soils, which, in turn, accelerates the lateral transfer of sediment to lower slopes and valley bottoms. Times of landform stability, or vegetation cover, are generally considered times of moist and cool environments. Conversely, times of dry and warm conditions promote landform instability.

\section{Short-Term Cyclicity}

Late Holocene sediments in the badlands terrain of Theodore Roosevelt National Park, Billings County, North Dakota, and in prairie settings of Knife River Indian Village National Historic Site, Mercer County, North Dakota, and along the north shore of Lake Sakakawea (Missouri River), McLean County, North Dakota, preserve records of numerous paleosols buried by alluvial deposits. Along the headwaters of Knutson Creek in Roosevelt Park, Ab horizons occur in minor sections $(<1.4 \mathrm{~m})$ with as many as ten paleosols. Although these were not dated directly, a date from a nearby section suggests formation of the paleosols over the last 1430 years (all dates are from AMS radiocarbon analyses). The Knife River Elbee Bluff Locality contains 


\section{Relationship Between Climate and Landform Stability and Paleosol Formation}

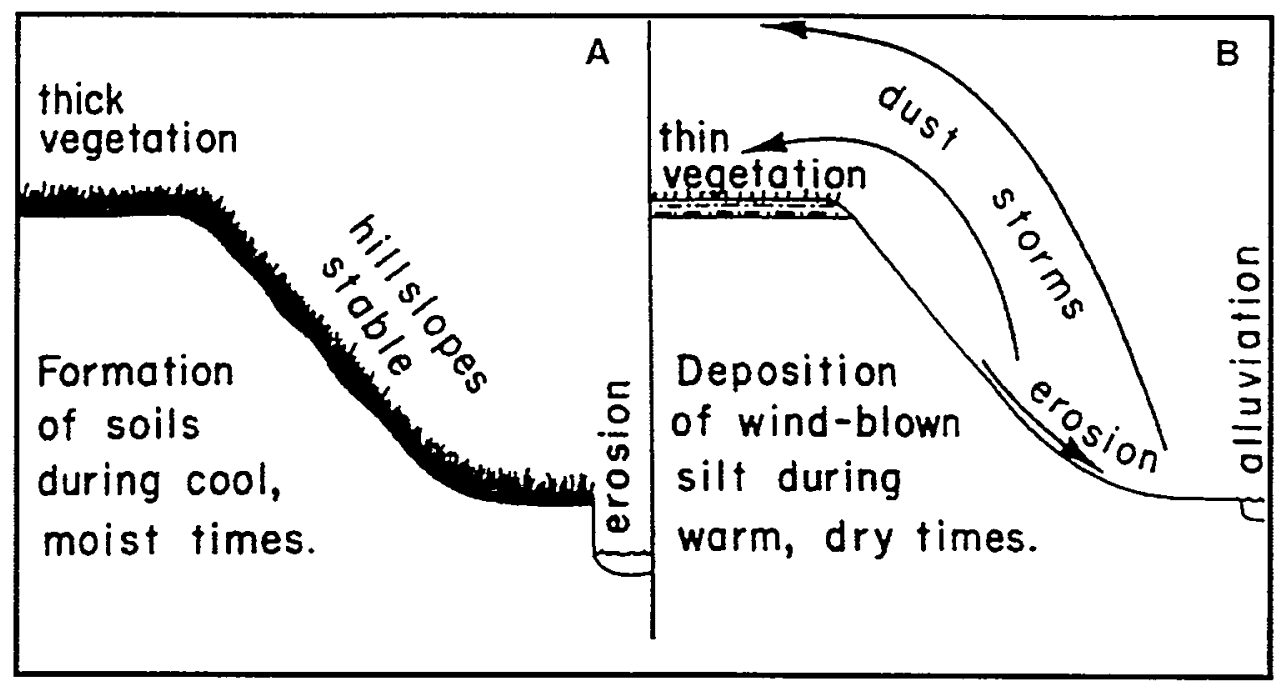

From Clayton and others (1976)

CL76-f5.cdar (1/8/98)

Figure ES-1. 1A. A time period of landform stability, with well-developed vegetation cover, soil formation, and limited erosion. 1B. A time period of landform instability, with thin vegetation cover, limited or no soil formation, and extensive erosion.

eight $\mathrm{Ab}$ horizons in a 2.4-m section, the middle portion of which has five thin, evenly spaced paleosols from about 2000 to 2974 years before present (YBP). The Lake Sakakawea Douglas Creek Locality consists of a stacked, apparently conformable sequence of $15 \mathrm{Ab}$ horizons in a 2.8-m section that can be traced laterally across a small paleovalley. The occurrence of paleosols at this locality can be interpreted over a span of 2655 years ( \pm analytical error). In the prairie setting of Douglas Creek, landform instability may have resulted in alluvial deposition on average about once every 170 to 180 years. The paleosol record preserved in both badlands and prairie localities indicates that soils seem to have been the result of relatively stable environments interrupted by brief episodes of burial every 140 to 200 years. The regularity of these burial events may stand as possible proxy indicators of minor climatic variation on an otherwise general record of climate stability. Stable carbon studies of these paleosols indicate generally cool and moist conditions ( $-22.6 \pm 0.6 \delta^{13} \mathrm{C}_{\mathrm{PDB}} \%$ ), except for those forming about $2585 \mathrm{YBP}$ (Douglas Creek) to at least $2165 \mathrm{YBP}$ (Elbee Bluff), during which warmer and drier conditions $(-20.0 \pm$ $0.4 \delta^{13} \mathrm{C}_{\mathrm{PDB}} \%$ ) more likely prevailed.

\section{Conclusions}

1. While difficulties exist in interpreting the timing of Ab-horizon paleosols in badlands and prairie terrains, present studies suggest that they may serve as potential climate proxy indicators for climate change. Although individual paleosol distributions in time and space at project study localities cannot be correlated directly to each other, their 
stratigraphic regularity under suggested allocyclic conditions at Locality M, Elbee Bluff, and Douglas Creek indicates the utility of paleosols in climate studies.

2. The key to further work is in determining a way to obtain information from the unaltered material between soil horizons. This could include using textural, radiometric, and structural information to reconstruct the environment of deposition. The depositional environment would indicate whether rapid or slow deposition has occurred. Also, in cases where soils are located in a well-studied area, the mineralogic composition of the material can be used to identify its source area in an effort to determine rate and distance of transport, which should also provide information about the environment.

3. Localities such as badlands that are excessively geomorphically dynamic should be augmented from other environmental study localities because the sedimentary records badlands preserve may mask more significant climate signals. Although these environments require more detailed work, they are still good candidates for short-term cycle study because there are highly sensitive to climate change.

4. Small-scale phenomena studies can identify periods of climate change. However, when separate locations are compared for the same time period, the indicated climates may not be identical. Factors such as differences in geomorphic processes, microclimates, and time delays are present in complex response relationships.

5. The climate model presented by Bluemle and Clayton ${ }^{1}$ suggested Holocene time intervals of greater and lesser geomorphic stability (e.g., Wolf Creek Unstable Episode, Thompson Stable Episode). The temporal occurrence of most project paleosols within stable episodes supports their general climatic framework. In addition, the formation of Section M8302 - Unit 31 paleosol at the Douglas Creek Locality may correspond to a break in the Altithermal (maximum warming).

6. The only evidence of significant $\mathrm{C}_{4}$ vegetative input was from the uppermost parts of the Elbee Bluff and Douglas Creek Locality sections. Radiocarbon dates suggest that a change to drier and warmer conditions commenced at about 2700 YBP.

7. The stable carbon data support the following theory by Knox ${ }^{2}$ : Hot, dry climates promote aggradation of material; cold, moist climates induce downcutting of stream channels and promote pedogenesis in other geomorphic settings. The stable carbon

1 Bluemle, J.P., and Clayton, L., 1982, Geologic time in North Dakota: North Dakota Geological Survey Educational Series 14, 18 p.

2 Knox, J.C., 1984, Fluvial responses to small-scale climatic changes in Costa, J.E., and Fleisher, P.J., Developments and applications of geomorphology: Berlin, Springer-Verlag, p. 318-342. 
data on organic matter from the soil horizons indicate relatively cool and moist climates in every case but one.

\section{Publications}

Beck, D.L., and Hartman, J.H., 1997, Paleosols as proxy climatic change indicators in central North Dakota: North Dakota Academy of Science, Proceedings, v. 51, p. 161.

Hartman, J.H., 1997a, The ever present chance of flooding, in Hartman, J.H., ed., Symposium on the Red River Flood of 1997-Involving Science in Future Watershed Management Decisions: North Dakota Academy of Science (1997 Annual Meeting), Proceedings, v. 51, Supplement 1, p. 51, 52.

Hartman, J.H., ed., 1997b, Symposium on the Red River Flood of 1997-Involving Science in Future Watershed Management Decisions: North Dakota Academy of Science (1997 Annual Meeting), Proceedings, v. 51, Supplement 1, 52 p.

Hartman, J.H., Beck, D.L., Kuehn, D.D., Reid, J.R., and Reiten, J., 1997, Paleosols as proxy data for climate change-Interpreting Holocene deposits in the badlands and prairies of western North Dakota: Geological Society of America, Abstracts with Programs, v. 29, no. 6, p. A-34.

A paper by Beck and Hartman (1997) was given as a presentation by Ms. Beck. She competed in the Denison competition for best graduate student paper and was named runner-up. A Master's student, Ms. Beck was competing with Ph.D. candidate dissertation studies. Hartman (1997a) presented at a special symposium of the North Dakota Academy of Science at an annual meeting in response to the catastrophic flooding of the Red River of the North in April of that year. Dr. Hartman coordinated and edited the supplement issue resulting from this meeting (Hartman, 1997b). Hartman and others (1997) gave a poster at the annual meeting of the Geological Society of America in Salt Lake City, Utah. 


\section{HOLOCENE CYCLICITY IN WESTERN NORTH DAKOTA - CLIMATE CHANGE INTERPRETED FROM FLUCTUATIONS IN ALLUVIAL SEDIMENTATION}

\section{INTRODUCTION}

This report is organized with the goal of providing the reader with a summary of basic results as an introduction to the project. A brief overview of the period covered by this project is given under The Holocene (p. 14). The Background section of this report (p. 16) provides summary information about individuals contributing to this effort and the field studies and other activities undertaken to accomplish project tasks. The Methodology section (p. 21) includes discussions and results of various analyses undertaken through the course of the project. This section includes ideas about how to conduct tasks toward interpreting the alluvial record of western North Dakota. Under Study Localities (p. 47), each area of study is reviewed in a systematic way, providing basic data and significance of the work. Publications produced as a result of this project are given in Appendix B.

Climatic variation during the Holocene (from 10,000 YBP to the present, Figure 1) has been documented through a variety of environmental indicators. Studies typically involve evidence of changes in the biota as a result of fluctuations in precipitation, reflecting periods of increased aridity followed by times of more equitable climate. Variation in the relative percentage of palynomorphs, indicating changes in vegetational patterns, has been widely used in areas with mixed vegetation types, where lakes or other depositional sinks are relatively common (Bradbury and others, 1993). Diatoms and ostracodes have been used to indicate variation in salinity of bodies of water in more arid environment, but such studies are associated with semipermanent bodies of water (Fritz and others, 1991, 1994; Engstrom and Nelson, 1991). In the southwest and elsewhere, variation in past climates has been interpreted from tree rings. Organisms used to track seasonal and general climatic variation as a function of habitability necessarily already live in a wet or generally compatible environment. In semiarid settings, which can be virtually devastated by drought, very little effort has been given to establishing a pattern of climatic variation recorded in cycles of alluvial sedimentation in highly erodible bedrock. The grasslands and badlands of the northern Great Plains conserve few permanent bodies of water to record variation in biotic productivity. These distinctive habitats do, however, record wet and dry periods by decreased and increased rates of cut and fill and by alluvial fan deposition. Unlike changes in the various biotic components of a diverse ecosystem, which may require substantial lag times to reflect climatic patterns, increased or decreased erosion and deposition may be an immediate reaction to wet and dry cycles. As a corollary, badlands sedimentation patterns are such a potentially sensitive environmental indicator that they may be capable of recording shortperiod cycles, thus providing additional objective information useful in correlating cause and effect.

The record derived from Holocene studies, regardless of interpretations, is one of change unaffected by human activity. An anthropogenic effect on climate systems seems certain (Figure 2), but a significant question is what effect humans have on an already varying 
system - thus the importance of climate studies that investigate changes in climate and interpret short-term cycle patterns.

\section{Original Objectives}

As proposed, the project attempted to validate or negate the thesis that alluvial sedimentation in badlands terrains records a pattern of climatic variation in response to cycles of lower and higher precipitation, which may correlate with predictable thermal fluctuations in solar cycles.

The infilling of coulees or gullies and their subsequent exhumation is a process that occurs throughout geologic history. Even over recorded history, casual observations by locals have noted gully filling followed by subsequent downcutting. These changes are recorded in literally thousands of short tributaries to major rivers, such as the Missouri River, or in the upper reaches of minor tributaries that are part of large drainage systems, such as the Little Missouri River. These depositional and erosional events in semiarid settings reflect changes in climate. The difficulty in reading this record of change is in finding geologic sections that preserve a detailed record of nearly continuous sequences of alluvial activity over an appropriate span of time and in developing rigorous methodologies to interpret the observed patterns.

\section{Premises and Interpretations}

\section{Basic Hypothesis Regarding Soil, Climate, and Geomorphic Relationships}

Before an interpretation of the data derived during the course of the present study is presented, some basic principles concerning the relationship between climate, soils, and geomorphic processes will be reviewed (Kuehn, 1997b, unpublished report). These relationships, and the specific models discussed, provide the necessary conceptual framework for subsequent interpretations. Key references include Schumm (1973), Langbein and Schumm (1958), Butzer (1976), Knox (1984), Derbyshire (1976), and Clayton and others (1976).

Climate, particularly insolation and moisture, has a direct influence on vegetation. Together, both climate and vegetation, rather than structural or eustatic changes or cultural modifications, are the major driving forces behind the weathering, erosion, transportation, and deposition of sediment (Derbyshire, 1976; Butzer, 1976; Peltier, 1950). Landscape form is therefore determined by the balance between deposition, erosion, and stability (Butzer, 1976; Knox, 1984) (Figures 3 and 4).

Several basic geomorphic models utilizing the above-mentioned climatic/geomorphic relationships have been developed within the last several decades. The one presented in Butzer (1976), taken from Erhart's (1967) concepts of biostasis and rhexistasis, is a good, albeit somewhat simplistic, example. Basically stated, during periods when landforms are stable, hillslopes are covered by a protective mat of vegetation and a balance is established between weathering (soil formation) and valley sedimentation. The weathering of surface sediments produces soils during periods of landscape stability. During periods of landscape instability, 
vegetation is significantly reduced, if not removed completely. This leads to slope disequilibrium as erosion outpaces soil formation. Disequilibrium results in the total and/or partial truncation of soils, which in turn accelerates the transfer of sediment to lower slopes and valley bottoms. Critical to this project, however, is the hypothesis that at the scale of individual geomorphic landscapes, change can also occur as a result of "complex response" to intrinsic variables (Schumm, 1973). Complex response is an active process in most landscape settings, especially fluvial, and is most acute in highly dynamic landscapes such as badlands, where geomorphic thresholds are in constant adjustment (Bryan and Yair, 1982). The concept of complex response as a causal factor behind local geomorphic variability is discussed below.

As demonstrated by Langbein and Schumm (1958), slope erosion and/or runoff is most directly affected by precipitation, although temperature is also a key factor, as it greatly affects evapotranspiration. In semiarid regions, including all of western North Dakota, the effects of temperature and precipitation on runoff and sediment yield are particularly salient (Langbein and Schumm, 1958; Knox, 1984). In such areas, rather modest changes in mean annual precipitation (i.e., $10 \%$ ) and temperature (i.e., $2^{\circ} \mathrm{C}$ ) can result in dramatic changes in mean annual sediment yield to valley settings in particular (Knox, 1984) (Figure 4). Therefore, periods of warm and dry climate valleys are likely to be associated with episodes of eolian, fluvial, and slopewash aggradation, as hillslopes and uplands are stripped of vegetation and sediment is eroded, transported, and redeposited (Figure 5). On the other hand, periods of cool and moist climate are likely to result in landscape stability and soil formation. Under these conditions, sediment yield from slope runoff and wind deflation is reduced, and streams, denied sediments, begin to cut down.

This model formed the conceptual framework for the interpretation of depositional and climatic environments associated with the late Pleistocene/Holocene-age Oahe Formation in North Dakota (Clayton and others, 1976; Figure 6). Studies in the badlands of western North Dakota and elsewhere have since verified the basic features of this pattern, but have also identified the importance of local geomorphic conditions and, hence, accentuate the need to consider scale when interpreting soil, climatic, and landform data (Kuehn, 1995).

On the scale of physiographic sections, subsections, and regions, the basic climate/landscape model of Knox (1984), Langbein and Schumm (1958), Clayton and others (1976), and others holds great promise. Problems arise at the local level or when an attempt is made to correlate patterns noticeable at a number of small, isolated localities scattered over a large region. The following discussion highlights some of the basic concepts of the large-scale model in light of the basic goals of the project.

In general, particularly in semiarid regions, episodes of alluvial aggradation, as represented by discrete accumulations of floodplain and former floodplain sediments at various elevations and ages, suggest that warm and dry conditions prevailed or were at least more prevalent during aggradational events. Episodes of valley downcutting suggest the opposite, that is, that cool and moist conditions prevailed during periods of alluvial degradation. The aggradation and degradation of windblown sediments (i.e., eolian or loess deposits) in western North Dakota appear to follow this same basic pattern (Clayton and others, 1976; Kuehn, 1995). 
Paleosols reflect periods of landscape stability. Landscape stability can result from a change in 1) climate, 2) local geomorphic conditions, and/or 3) other factors such as tectonics, eustatic activity, biologic activity, cultural activity, and fire. As a causal factor behind paleosol formation, climate is suspected when 1) synchronous soils are widespread and correlated beyond individual localities or drainage basins, 2) soil formation is occurring at multiple places at the same time, or 3) stable carbon isotope and other proxy sources indicate that soils are associated with episodes of cool-moist climate. Local geomorphic conditions are suspected 1) in extremely dynamic landscapes such as badlands, 2) when soils are thin and discontinuous at a single location (e.g., Figure 7), 3) when soils are generally thin and cannot be correlated within even a single drainage basin, and 4) when soils, regardless of thickness, cannot be correlated between different drainage basins or physiographic regions.

In western North Dakota (Figure 8), these climate, soil, and geomorphic relationships strongly suggest that investigations must focus on the analysis of data at all scales, including 1) intrasite, or small, scale (i.e., within a single stratigraphic section); 2) intersite, or medium, scale (i.e., between different stratigraphic sections within the same subregion); and 3) large scale (i.e., between subregions, regions, and provinces). The types of data to be considered in such multiscaled investigations include 1) geomorphic setting; 2) geomorphic history; 3) soils (including thickness, level of development, and correlation); 4) unit contacts and general stratigraphy; 5) evidence of geological unconformities; 6) textural changes and changes in depositional environments; and 7) proxy climatic data, such as stable carbon, pollen, phytoliths, diatoms, and snails.

In order to draw meaningful inferences concerning the relationships between climate, geomorphology, and soils, research must focus initially at the intrasite, or locality, level where geologic sections are measured. This represents the main emphasis of the project reported here. Subsequently, however, data concerning intersite correlations and regional phenomena must be incorporated to weigh the significance of local results and interpretation. The goal of this project was to determine if short-term cycle patterns are present in geomorphically dynamic terrains and to place these observations into a regional and, perhaps, global context.

\section{Interpretations}

Following the principles outlined in the above basic landscape/climatic model, especially the need to focus on various scales or levels of information, the discussion below concerns project data in a larger regional-interregional perspective. In other words, what similarities, differences, or possible patterns emerge from an interpretation of the soil, geomorphic, and radiometric records from the study sections as a whole? The following discussion refers to project localities in Billings County (Localities C, D, and M), Mercer County (Elbee Bluff Locality), and McLean County (Douglas Creek and Riverdale localities) in western North Dakota.

Unfortunately, little in the way of substantive comparable data was recovered from Localities $\mathrm{D}$ and $\mathrm{M}$ in the Little Missouri badlands physiographic region. This is due largely to 1) the paucity of radiocarbon dates; 2 ) the possibility that the crux of the investigation was 
limited to loess and/or colluvial mantles that cover the major localities and may be substantially younger than the underlying alluvium; 3) the nature of geomorphic processes in badlands environments, which are unlike those of other landscapes in that they are extremely dynamic and sensitive to both climatic and local geomorphological variability; and 4) proxy data regarding paleoclimatic conditions, particularly stable carbon isotope analyses, being inconclusive or demonstrating little change through time. This is contrary to previous paleoclimatic studies that concentrated on upland landforms in the region (Kuehn, 1995) of which the results may be attributed to the riparian settings of the study sections. Both studies were from perennial stream locations where evidence of climate change via fluctuations between $C_{3}$ and $C_{4}$ biomass may have been masked by greater water availability and the riparian nature of the localities.

In very broad terms and in a manner not particularly well-suited to interregional correlations, the following inferences may be drawn from the badlands data:

1. Previous research indicates that relatively warm and dry conditions prevailed during the aggradation of the area's four major terrace fills (T4, 7000-6000; T3, 5500-4500; T2, 2700-800; and T1, 400-150 YBP).

2. From Terrace T2 at Locality D, it can be argued that three episodes of landscape stability and limited soil formation were interrupted by valley aggradation between about 2700 and 800 YBP.

3. From the probable loess/colluvial mantle at the top of T4 alluvium at Locality D, it appears that during the last approximately 1400 years at least six periods of landform stability and soil formation were interrupted by periods of aggradation.

4. From Terrace T1 at Locality D, it appears that at least two periods of stability occurred within the last approximately 300 years.

5. Because of a complete lack of direct chronological control, the data derived from Locality $\mathrm{M}$ cannot be correlated with those from other sections at this time (see below).

Although charcoal was recovered from Locality $M$, the samples were too small to permit radiocarbon analysis. The age relations of Localities $\mathrm{D}$ and $\mathrm{M}$ may possibly be inferred to be approximately the same on the basis of the similarity of the shape of the stable carbon curves for the two localities. The possibility that 10 paleosols of Locality $\mathrm{M}$ formed in the last $1430 \pm$ 50 years indicates landform instability on the order of every 140 years or so. That the thin paleosols of Locality $M$ may be autocyclic in nature is possible. However, the similar pattern of stable carbon data between Localities D and M possibly suggests a similar span of time (H.E. Wright, verbal communication, 1997).

The likelihood that individual soils at either Locality D or M are chronostratigraphically equivalent to soils outside of the badlands region is slim. Indeed, even the correlation of soils within a single drainage system appears difficult at best. Geomorphic processes such as slopewash deposition, gulling, piping, and mass movement are virtually ongoing and certainly 
affect local conditions of landscape stability, deposition, and erosion. Take, for example, the following hypothetical example:

An episode of mass wasting in one localized area creates a rapid increase in sediment yield to immediately adjacent valley bottoms. Because this same depositional episode did not occur elsewhere, a situation of base-level disequilibrium occurs among streams in the same drainage basin. This crossing of a local geomorphic threshold in turn leads to the initiation of gullying and headward erosion within the basin as the affected member streams attempt to compensate for this difference in base level (Patton and Schumm, 1975).

Under such a scenario, landscape instability occurred at the site of the mass wasting (in the form of erosion), immediately downhill in the adjacent valley (in the form of deposition), and in areas farther downstream (in the form of gullying). Similar complex response scenarios can be initiated by the formation and collapse of pipes and from highly disparate rates of slopewash deposition and hillslope lowering. These localized processes are related to a number of factors, particularly 1) to variable lithologic composition among exposed slopes, which can range from highly impermeable clay to very weakly cemented sandstone and 2) to slope aspect, which affects the amount of solar radiation reaching the surface, which in turn influences vegetative cover and slope morphology (Clayton and Tinker, 1971). Badlands environments, especially in lowland, hillslope, or valley settings, are extremely complex in terms of the number and timing of geomorphic processes. While research in more stable upland badlands settings has indeed yielded significant information on changing climatic conditions during the Holocene, the same cannot be said of lowland settings, other than making climatic inferences based on the timing of areawide periods of valley aggradation and degradation.

Note, however, these same types of highly varied, localized geomorphic processes can, and do, occur in nonbadlands landscapes (Bryan and Yair, 1982; Campbell, 1989; Ritter, 1978). They are just not as common or widespread. The possibility of similar small-scale changes and adjustments in local landscapes does have ramifications for interpretation at all study sections.

By far, the most useful data regarding the relationship between Holocene climatic conditions and alluvial sedimentation were those derived from the Elbee Bluff and Douglas Creek localities. Both demonstrate the highest degree of buried soil development (or at least the thickest), and both have good-to-excellent chronological control. A word of caution, howeverat both sections there are stratigraphic characteristics that could complicate the drawing of certain climatic/geomorphic inferences. At Elbee Bluff, for example, there is uncertainty as to the depositional environment associated with the upper approximately $0.3-0.8 \mathrm{~m}$ of sediment. Reiten (1983; 1996, unpublished report) suggested that a period of downcutting of the Knife River channel occurred sometime between about 2000 and 1100 YBP. This incision created Terrace A and led to the aggradation of a lower floodplain. If this were the case, it would have been very difficult for the Knife River, under normal flood regimes, to deposit other than very fine-grained (i.e., suspended load) sediments to the top of the A surface during subsequent flood events (Brakenridge, 1987). The textural data obtained as a result of this study, however, indicate a slight decrease in clay and a rather significant increase in sand in the deposits above Units 5 and 
6 (Section M8299a). This leaves open the possibility that eolian processes may have been responsible for the deposition of the upper portion of the exposure.

At Elbee Bluff, there are no less than eight episodes of landscape stability and soil formation over a period of about 2000 years, while at Douglas Creek, the number rises to 15 during a roughly 3000-year interval. These are impressive pedogenic/geomorphic records. Given these general observations, what pedogenic events or groups of events stand out as potentially significant at the regional and interregional scale? In the case of the Elbee Bluff Locality, there is good evidence for soil formation under relatively cool and moist conditions from about 3900 to $3800 \mathrm{YBP}$ ( \pm analytical error) and from 3300 to $2900 \mathrm{YBP}$ ( \pm analytical error). In addition to the soils themselves, mesic conditions in all instances are evident on the basis of the $\delta^{13} \mathrm{C}$ data, which indicate the predominance of $\mathrm{C}_{3}$ plants during these intervals. The only evidence of significant $\mathrm{C}_{4}$ vegetative input was recovered from Unit 9 (Section $\mathrm{M} 8299 \mathrm{a}$ ), a thin soil that appears to have formed shortly before about 2000 YBP. Short-term cycles at the Elbee Bluff Locality may be evidenced by the middle portion of the section, which has five thin, evenly spaced paleosols from about 2000 to 2974 ( \pm analytical errors) YBP. A potential average occurrence of landform instability may be about 195 years.

At the Douglas Creek Locality, on the other hand, a cross-sectional view reveals a concave, basinlike depression. Several of the thickest (and most fine-grained) soils are those in the bottom of the basin. These, as well as several others, appear to pinch out laterally along the sloping sides. This type of morphology suggests that Section M8302 may have contained some sediments that are at least partially paludal in origin (Picard and High, 1972). Additional evidence for ponding may be indicated by the phytolith data (Fredlund, 1997, unpublished report); samples from the lowest and deepest portion of the possible depression suggest climatic conditions more mesic than those of modern times. If indeed a ponded environment did exist, in some respects the data recovered from Douglas Creek may not be representative of so-called "normal" alluvial terrace and floodplain fills along other meandering streams in the northern plains. However, in the absence of additional data, including soil chemical and organic composition, diatoms, pollen, or freshwater snails, such a possibility must be viewed as tentative. There is every reason to believe that significant and applicable information regarding Holocene climatic and geomorphic relationships can be recovered from paludal or eolian sediments. They have in fact been recovered from other northern plains areas (Barnosky, 1989; Boutton and others, 1997; Kuehn, 1995; Laird and others, 1996).

In the case of the Douglas Creek Locality, there is good evidence for soil formation at about 5200, 3500, between about 3200 and 3000, about 2500, and to a lesser extent, possibly about $2200 \mathrm{YBP}$ ( \pm analytical errors). Again, high negative $\delta^{13} \mathrm{C}$ values suggest that all of these episodes, with the possible exception of the last group, occurred under mesic (or at least cool and presumably moist) conditions. Paleosols represented by Units 3 and 5 (Section M8302) record the most significant increase in the influence of $C_{4}$ vegetation, suggesting generally warmer and drier conditions. An average occurrence of paleosols at the Douglas Creek Locality can be interpreted from the conformable sequence of $15 \mathrm{Ab}$ horizons. Over a span of 2655 years ( \pm analytical error), landform instability resulted in alluvial deposition on average about once every 170 to 180 years. The paleosol record preserved at all three localities indicates that soils are 
the result of relatively stable environments interrupted by brief episodes of burial every 140 to 200 years. A statistical analysis on the Douglas Creek Locality record. using a lognormal distribution (see Methodology, p. 21), indicates a maximum recurrence interval of 250 years (with a $90 \%$ probability).

At both the Elbee Bluff and Douglas Creek Localities, periods between soil-forming intervals appear to correspond to episodes of alluvial aggradation. Under our basic climatic/geomorphic model, it could be further argued that these periods were relatively warm and dry. If so, xeric conditions may have been present between about $3700 \longrightarrow 3500$ YBP (at Elbee Bluff, especially) and between about 2900 $\rightarrow 2600$ YBP (at Douglas Creek, especially). Finally, the stable carbon data in particular appear to indicate that both sections experienced somewhat warmer and dryer conditions toward 2000 YBP. These are among the strongest and most convincing examples of potentially nonlocal pedogenic episodes that may have direct bearing on Holocene climatic conditions in western North Dakota. Additional interpretations relevant to larger-scale interregional correlations are possible, but are based on weaker evidence (see Reflections and Future Studies section below).

Little substantive information of relevance to project goals was recovered from the Oahe Formation stratotype at the Riverdale Locality. This was due to a complete lack of radiometric data, which is an unfortunate result of the paucity of datable materials at this location (Clayton and others, 1976). One bone sample recovered was too poorly preserved to permit radiocarbon dating. However, the one interesting set of data that did emerge from this study shows the similarity between the stable carbon isotope values from Section M8300 and those from analogous Oahe Formation loess units in the Little Missouri badlands. That is, the highest $\mathrm{C}_{3}$-like values were from samples from the late Pleistocene-early Holocene Aggie Brown Member, followed by a steady increase in $\mathrm{C}_{4}$ biomass through time, which reached a peak in the lower Riverdale Member. This was followed by a significant increase in $\mathrm{C}_{3}$ biomass within the last several thousand years (Kuehn, 1995; Boutton and others, 1997). While these similarities have important ramifications concerning climatic conditions and loess deposition in western and westcentral North Dakota since the late Pleistocene, they have little bearing on the interpretations derived from the other project sections (which are principally alluvial and limited to the middle and late Holocene).

\section{Reflections and Future Studies}

This project yielded a number of important results for future work with paleosols and other climate proxy data in terrestrial settings. The major goal of relating Holocene climate and alluvial activity in western North Dakota was accomplished. By using a number of analytical techniques, including the analysis of soils and stratigraphy, texture and other physical properties, stable carbon isotopes, phytoliths, and radiocarbon samples, the study identified several pedogenic episodes that appear to cross-cut local areas and therefore offer meaningful insights into climate change on a regional or interregional basis. This is particularly true of significant portions of the late Holocene, that is, the period between 4000 and $2000 \mathrm{YBP}$. 
In contrast to the late Holocene, data regarding climatic/geomorphic relationships during the early and middle Holocene are woefully lacking: stable carbon isotope values are in some cases problematic and inconclusive, pollen analysis proved totally unproductive; phytolith analysis provided information of only marginal utility, and radiocarbon dating proved unsuccessful or of only limited value at some localities. Some of these problems are due to the inherently poor preservation potential for microfloral remains and charcoal in this portion of the northern plains. Causal factors related to specimen preservation are likely to include precipitation and temperature, high soil pH, soil texture, and frequent wetting and drying (Bryant and Hall, 1993). While finding more substantive microfloral remains in this particular region may prove to be a chronic and largely unavoidable problem (Kroeger, 1996, unpublished report), opportunities should increase if investigations are focused on areas that are not as susceptible to high $\mathrm{pH}$ and frequent wetting and drying. In the case of the latter, perennially wet localities such as bogs, lakes, or spring-fed ponds would be a good place to start. Indeed, these types of environments have been the hallmark of successful pollen-derived climatic inferences since the discipline of palynology was established. A hope for the project was that palynomorphs would be sufficiently abundant to be picked and used for radiocarbon analysis. Although this possibility still exists, samples collected lacked sufficient palynomorph density to make this effort practicable.

The paucity of suitable radiocarbon samples is perhaps the greatest obstacle to answering the broad temporal questions integral to certain parts of this study (i.e., short-term cycle patterns). One way to overcome this problem may be to examine large portions of preselected drainages first and then base the selection of sections at least in part on the availability of charcoal or other materials suitable for radiocarbon dating. In other words, concentrate field efforts in those areas where we are fairly certain of obtaining good chronological control. This does not mean that every study section should have a minimum of five, ten, or, say, fifteen radiocarbon age determinations. Rather, those soils or other types of sediment that appear to have the potential to contribute to the project's goals significantly should themselves be extremely well dated. In some instances, this could be accomplished by collecting good datable samples from the target soil itself and from areas immediately above and below the sample, thus bracketing the age of the event in question (Haynes, 1968). In any case, more radiometric data are crucial.

Other difficulties encountered also concern preservation of soils and sediments in highly dynamic environments. Included in this problem is the ever-present possibility that large-scale patterns could frequently be masked by the response of complex geomorphic processes to intrinsic variables. Solutions here could lie in limiting investigations to landscapes that do not appear to be highly geomorphically dynamic (in contrast to badlands). Rather than totally excluding the more dynamic areas, however, future study could focus more on settings that are less geomorphically unstable, such as uplands. Significant climatic/geomorphic data have been and will undoubtedly continue to be recovered from upland loess localities in the Little Missouri River badlands and elsewhere (Kuehn, 1995; Boutton and others, 1997).

Including environments other than drainage basins for future study could enhance data collection in other ways as well. For example, the recovery of samples from nonriparian settings may result in stable carbon isotope data that are more amenable to widespread interpretation. 
That is, samples collected from nonalluvial or lacustrine settings should yield values that are not as susceptible to bias by highly localized conditions of increased moisture.

One last potential problem is the pedogenic makeup of those sections that were selected for study. In most cases, such sections were typified by unusually large numbers of buried soil horizons: fifteen at Douglas Creek, eight at Elbee Bluff, six or more at Locality D, and ten at Locality M. Perhaps the goal of explaining climatic-geomorphic relationships during the Holocene could better be achieved by concentrating future investigations on sections with fewer, but more well-developed, soils, that is, soils that are thicker and contain multiple horizons or evidence of pedogenic translocation and depletion. These types of paleosols should not be as susceptible to formation by highly localized geomorphic conditions and therefore should be more conducive to regional correlation. However, multiple-horizon soils would, by definition, reflect more of an average of conditions over time than the single A horizons found under geodynamic conditions.

Focusing research on sections with numerous, but thin and ephemeral, soils is in some ways analogous to attempting to establish a dendrochronology curve in an area where trees and other products of the environment have never been systematically studied. As with tree rings, the thickness of buried soils is certainly indicative of something, be it conditions of rainfall and precipitation or merely local geomorphic variability. Buried soils do indicate periods of landscape stability, just as thicker tree rings in general do indicate more favorable growing conditions. Lessons learned in dendrochronology, however, indicate that not all species of trees are suitable for dendrochronological dating. Likewise, conclusive results for soils, especially those with substantial temporal spans, require tremendous research efforts over extremely large areas (Baillie, 1982).

\section{Proposed Collaborative Studies}

Meetings with Dr. Leon F. Osborne, Jr., Director of the Regional Weather Information Center at the University of North Dakota, have been held to determine how to integrate climate modeling with late Holocene geologic data. It seems possible that data derived in this project, such as cycle duration information, might be used to constrain climate models in two ways: 1) as a means to interpret weather pattern conditions that would result in cycles of weather on the order of some period of time (e.g., 170 years) and, 2) provide input as to the climate conditions that may have prevailed during various intervals of time (e.g., cool-moist to warm-dry).

\section{Abbreviations/Terminology}

This section defines standard and informal abbreviations used herein. Definitions of some terms are included for clarity. 


\section{Miscellaneous Abbreviations}

$\begin{array}{ll}\text { AMS } & \text { Accelerator mass spectrometry } \\ \mathrm{Ka} & \text { Thousands of years before present } \\ \mathrm{KRIV} & \text { Knife River Indian Villages National Historic Site } \\ \mathrm{Ma} & \text { Millions of years before present } \\ \mathrm{n} & \text { Number of observations } \\ \mathrm{R}^{2} & \text { Correlation coefficient } \\ \mathrm{SD} & \text { Standard deviation }\end{array}$

TRNP Theodore Roosevelt National Park

UAZ University of Arizona National Science Foundation Arizona AMS facility

USGS U.S. Geological Survey (All quadrangles referred to in this report are 1:24,000scale, 7.5-minute topographic maps.)

WHOI-NOS Woods Hole Oceanographic Institute National Ocean Sciences

YBP Years before present

\section{Standard Soil Horizon Terminology (Figure 7)}

A Modern soil horizon

$\mathrm{Ab} \quad$ Buried A horizon

C Unaltered sediment horizon

\section{Texture and Color Terminology}

Texture terms (e.g., silt loam) are based on grain size (e.g., clay, silt, sand) and are plotted on ternary diagrams (Figure 12). Graphical texture symbols used in this report are shown in Figure 13.

Colors mentioned in this report are based on Munsel $1^{\circledR}$ Soil Color Charts. Colors are referred to by name and designation, such as olive brown, $2.5 \mathrm{Y} 4 / 3$, which represents hue (2.5Y), value (4), and chroma (3). 
Other Soil/Terrace Abbreviations

S-number of Kuehn

Represents a soil couplet number (e.g., A and C horizons)

S-number of Reiten

Represents a soil number (e.g., A horizon)

T-number of Kuehn

Terrace number $($ Terrace $1=T 1)$

\section{Selected Definitions}

Allocyclic

Deposition that results from changes in the supply of energy or material input to a sedimentary system; changes external to the sedimentary unit.

Alluvial

Pertaining to or composed of alluvium or deposited by a stream or running water.

Altithermal

A time during the Holocene when temperatures were warmer than at present ( $\approx$ thermal maximum, Holocene maximum) (7500-4000 YBP).

Autocyclic

Deposition that requires no change in the total energy and material input to a sedimentary system, but involves simply the redistribution of these elements within the system (such as channel migration).

Biostasis

A condition where the maximum development of organisms occurs at a time when residual soils form extensively on land.

Colluvium

A general term applied to any loose, heterogenous, and incoherent mass of soil material and/or rock fragments deposited by rainwash, sheetwash, or slow continuous downslope creep, usually collecting at the base of gentle slopes or hillsides.

Cumulic

The accumulation of mineral material onto the surface of the soil

(cumulization) by either air or water, which may be considered a geogenic rather than a pedogenic process. The effects of this process are most evident in depressional areas where material eroded from soils upslope has accumulated.

Entisol

A soil order characterized by the dominance of mineral soil materials and absence of distinct pedogenic horizons other than A horizons.

Eolian

Pertaining to the wind, especially said of such deposits as loess. 
Holocene

Hypsithermal

Loess

Mesic

Paludal

Paleosol

Palynomorph

Pedogenic

Phytolith

Rhexistasis

Other Terms

M-number

Township (T.) and Range (R.)

Section (sec.)
An interval of time or series of rock of the Quaternary period/system, from the end of the Pleistocene, 10,000 YPB, to the present time $(\approx$ Recent).

A time during the Holocene when the mean annual temperature exceeded those of the present (see Figure 3).

A widespread, homogeneous, commonly nonstratified (nonlayered), porous, friable, slightly coherent, usually highly calcareous, finegrained blanket deposit, consisting predominantly of silt.

A habitat or environment receiving a moderate amount of moisture.

Pertaining to a marsh.

A soil that formed on an ancient landscape ( $\approx$ buried soil, e.g., Ab horizon).

A microscopic, resistant-walled organic body, including pollen, spores, acritarchs, and other sedimentary deposit microfossils.

Pertaining to soil formation.

A mineral structure, typically of opaline silica and generally microscopic, secreted by a living plant.

The mechanical breaking up and transport of old soils or other surface residual materials.
An M-number (e.g., M8302) is a number applied by Hartman as part of a system to track information on geologic sections and other observations.

Refer to a legal location system used in many western states. A township generally includes 36 numbered sections. Each township is located in a type of compass-based cartesian coordinate system, with townships numbered north $(\mathrm{N})$ and south (S) and ranges numbered east (E) and west (W). A township and range number identify a specific township (e.g., $\mathrm{T}$. 140 N., R. 67 W.).

A section is numbered from 1 to 36 and is generally a surveyed area of about $1 \mathrm{mi}^{2}\left(2.56 \mathrm{~km}^{2}\right)$. Sections are typically divided in 
quarters based on compass quadrants $\left(\mathrm{NE}^{1 / 4}\right)$ and further subdivided. Divisions are read from smallest to largest areas: $\mathrm{NE}^{1 / 4}$ $\mathrm{SE}^{1 / 4} \mathrm{sec} .4$ represents an area of 40 acres $\left(4000 \mathrm{~m}^{2}\right)$.

Section

When not used in reference to a location, a section refers to sequence of rock layers ( $=$ units). A surface exposure where thicknesses are determined is typically said to be a measured, or geologic, section.

\section{THE HOLOCENE .}

The focus of this project is on climate change as interpreted from paleosols during the middle-to-late Holocene. The Holocene, also known as the Recent, is a geologic term used for the last 10,000 years or so of earth history (Figure 5). The preceding Pleistocene Epoch encompasses geologic time from 1.64 Ma to the Holocene and is a time of major climatic shifts resulting in extensive continental glaciation. The boundary between the Pleistocene and Holocene is a climatic event resulting in the loss of nonpolar glaciers and a reduction in the extent of mountain glaciers. Interpretations of Holocene climate trends in the central interior of the United States are given in Figures 3-5. Far from a period of climatic stasis, the last 10,000 years is a time of significant variation in temperature and precipitation. These variations resulted in vegetation shifts that would significantly affect today's populations by altering sea level, productive crop zones, and areas of disease associated with warmer temperatures (e.g., spread of malaria). Climatic shifts are reflected in sedimentary processes such as cut (erosion) and fill (aggradation or alluviation) (Figure 5). Periods of landform stability and instability are related to climate stability and climate change. Periods of stability lead to the formation of soils. These natural changes in climate undoubtedly had significant influence on the history of the earth's people and will without doubt continue to do so.

In North Dakota, the Oahe Formation represents all of the sediments overlying the Coleharbor Formation (Clayton and Moran, 1979). This spans an age of late Pleistocene (Wisconsinan) through the Holocene to the present (Clayton and others, 1976) (Figure 6). Project samples were collected from as far back as 10,000 years ago (from the Leonard Paleosol), but the focus of the project is on the late Holocene Riverdale Member. Clayton and others (1976, p. 12) suggests that the late Holocene "probably fluctuated between periods that were fairly cool and humid like today and periods that were a few degrees warmer and perhaps $100 \mathrm{~mm} /$ year drier, like the 1930s" (compare with Figure 2). As noted by Clayton and in this report, changes in climate would likely result in changes in hillslope or landform stability. Clayton and others (1976, p. 12) states:

After vegetation became established in latest Wisconsinan time, there were probably periods when -

- the climate was cool and moist,

- vegetation stabilized hillslopes, 
- little hillslope erosion took place on steep slopes,

- little eolian silt was deposited on gentle slopes,

- soil formation took place, and

- dark subdivisions of the Oahe Formation formed.

These alternated with periods when -

- the climate was warm and dry,

- little vegetation stabilized the hillslopes,

- considerable hillslope erosion took place on steep slopes,

- considerable eolian silt was deposited on gentle slopes,

- little soil formation took place, and

- light-colored subdivisions of the Oahe formed.

Clayton and others (1976, p. 13) stresses that "where the Oahe Formation is thick (such as along the bluffs of the Missouri River [e.g., Douglas Creek Locality]) the surface soil is developed entirely in sediment of late Holocene age in response to climatic conditions for the most part similar to those of today."

Project sections occur primarily in the Riverdale Member of the Oahe Formation. The Riverdale Member was named for the town of Riverdale located $4 \mathrm{~km}$ to the south. The Riverdale Member was first described by Clayton and others (1976, p. 6, 7) as a silt loam about $1 \mathrm{~m}$ thick near the Missouri River and divisible in many places into three units of roughly equal thickness that are differentiated on the basis of color:

- Upper member - commonly grayish brown (10YR 5/2, dry); noted as frequently lighter in upper few centimeters

- Middle member - commonly light grayish brown (10YR 6/2, dry)

- Lower member - commonly grayish brown (10YR 5/2, dry)

Texture, clay mineralogy, and carbonate components of the Riverdale Member are illustrated in Figure 9. In contrast to its stratotype, the Riverdale Member is significantly thicker at the Douglas Creek Locality. Colors at this locality also differ, ranging in paleosols from dark gray to very dark gray (2.5Y 4/1-3/1, dry-wet) to light olive brown (2.5Y 5/3, wet) to C-horizon colors of light olive brown or light yellowish brown (2.5Y 5/3-6/3, dry) to olive brown to light olive brown (2.5Y 4/3-5/3, wet). Along with its numerous paleosols, the Douglas Creek Locality appears to represent an important reference section for the Riverdale Member and the late Holocene. However, differentiating submembers, as reported by Clayton and others (1976), are not likely at the Douglas Creek Locality (see Douglas Creek Locality, p. 57).

Bluemle and Clayton (1982) (Figure 10) suggests various episodes of stability and instability during Oahe Formation time. The present project encompasses, from oldest to youngest, the latter part Wolf Creek Unstable Episode, Thompson Stable Episode, an unnamed 
unstable episode, and Mandan Stable Episode. The general occurrence of our paleosols within these temporal intervals suggests support for the Bluemle-Clayton general climate framework.

\section{BACKGROUND}

\section{Personnel}

Dr. Joseph H. Hartman, Energy \& Environmental Research Center (EERC), coordinated project activities, led all field studies, served as a member of Ms. Beck's Master's thesis committee, and produced the final report with the assistance of project staff. Dr. Hartman has extensive experience in western North Dakota stratigraphy and fieldwork, incorporating a paleontologic perspective, and has led or participated in a number of collaborative projects. Project participants are introduced below.

Dr. John R. Reid (Department of Geology and Geological Engineering, University of North Dakota) was a consulting project scientist and chairman of Ms. Beck's Master's thesis committee. Dr. Reid, who discovered the Douglas Creek Locality, participated in the May and June field studies and assisted Ms. Beck in her work at the Douglas Creek Locality. He also took part in discussions and a poster presentation at the annual meetings of the Geological Society of America in Denver and Salt Lake City. Dr. Reid's expertise includes Holocene geologic history and alluvial processes of western North Dakota. He has had a long research interest in resolving the record of climatic variation in the sediments preserved along the Missouri River.

Dr. David D. Kuehn (Department of Anthropology, Texas A\&M University) served as a consulting project scientist. He participated in the June field study and took part in data reduction and interpretation. His expertise in this project was developed in part from establishing a terrace formation chronology based on the sedimentary record of the Little Missouri River badlands of western North Dakota and its paleoclimatic interpretation for the purpose of providing a stratigraphic and paleoenvironmental context for the archaeological record (Kuehn, 1995).

Mr. Jon Reiten (Montana Bureau of Mines and Geology, Montana State University) served as a consulting project scientist in the June field study and took part in interpretations regarding the Elbee Bluff Locality. Reiten also assisted in the poster presentation at the annual meeting of the Geological Society of America in Salt Lake City. His expertise in this project was developed in part from studies undertaken in the area of the Knife River Indian Villages National Historic Site (Reiten, 1983). Mr. Reiten specializes in Holocene sedimentation and climatic interpretation.

Ms. Deborah L. Beck (Department of Geology and Geological Engineering and EERC, University of North Dakota), with an undergraduate degree from Case Western Reserve University, served on the project as a graduate research assistant. Ms. Beck participated with the crew in June field studies and conducted her graduate fieldwork at the Douglas Creek Locality in June and July. She also performed texture analyses on sediment samples collected for the project. Ms. Beck presented a paper (Beck and Hartman, 1997) at the North Dakota Academy of Science annual meeting and contributed to a poster and its presentation (Hartman and others, 1997) at the 
Geological Society of America annual meeting. For her Academy presentation, Ms. Beck was runner-up in the Denison competition for best graduate student paper. A Master's student, Ms. Beck was competing with Ph.D. candidate dissertation studies.

Mr. Peter R. Hartman (Natural Resource Conservation Service, Soil Conservation Service, Minneapolis, Minnesota) participated in the October field trip to the localities studied in June. He assisted in describing sections at the Knutson Creek and Elbee Bluff Localities and collecting additional samples, along with making observations at the Douglas Creek Locality.

Dr. Timothy J. Kroeger (Department of Geology, Bemidji State University) served as a consulting project scientist in laboratory studies and interpretation of palynomorphs collected as a result of this project. Dr. Kroeger is a palynologist specializing in the sedimentological and paleoenvironmental context of palynomorph assemblages, as well evaluating their potential for bias resulting from natural depositional processes.

Dr. Thomas W. Boutton (Department of Rangeland Ecology and Management, Texas A\&M University) conducted stable carbon isotope analyses and provided some interpretation of the results.

Dr. Glen G. Fredlund (Department of Geography of the University of WisconsinMilwaukee) conducted phytolith analyses and provided some interpretation of the results.

Other contracts included AMS radiocarbon dating of charcoal by the National Ocean Sciences AMS facility at Woods Hole Oceanographic Institution. Project administration was undertaken by Ms. Susan Handwork, and petrographic analysis of carbon clast samples was conducted by Ms. Lorraine Eglinton. Radiocarbon dating of bone samples was undertaken by the National Science Foundation Arizona AMS facility at the University of Arizona. Project administration was conducted by Ms. Rosemary Maddock and Dr. G.S. Burr.

\section{Field Studies}

Initial study areas were chosen for examination on the basis of previous field observations by others who had reported recurring depositional patterns. Unpublished information indicated that these locations represent a sedimentary record spanning the late Holocene (from approximately 5000 years ago to near modern times). In late May 1996, Reid and Hartman visited potential sampling sites northeast of Medora (Jones Creek), north of New Town (Little Knife Bay), near Stanton (Knife River-Missouri River, and southeast of Emmet (Douglas Creek) in western and central North Dakota. Permission to explore Jones Creek in Theodore Roosevelt National Park was granted by the National Park Service (Research Activity Permit, Appendix A). On the basis of these site examinations and considerations given to previous studies by Kuehn (1995) and Reiten (1983), geologic sections of the Oahe Formation at localities in the Medora, Stanton, Emmet, and Riverdale areas were chosen for sampling. In June 1996, a field crew consisting of Hartman, Reid, Kuehn, Reiten, and Beck sampled paleosol sections northwest of Medora (Knutson Creek, Localities D and M), north of Fryburg (Locality C), near Stanton (Elbee Bluff), southeast of Emmet (Douglas Creek), and north of Riverdale (Riverdale). Permission to 
study the Knutson Creek and Fryburg Localities in Theodore Roosevelt National Park was granted by the National Park Service (Research Activity Permit, Appendix A). We were aided at the Knutson Creek Localities by Theodore Roosevelt National Park ranger Brian Kouba. The crew received permission from Chief Ranger Bill Lutz of the Knife River Indian Villages National Historic Site to study and sample the area of Elbee Bluff. Sediment samples were collected for textural, pollen (for possible environmental interpretation as well as radiocarbon dating), stable carbon isotope, radiocarbon (from charcoal and bone), and phytolith analyses. All localities were spotted on USGS 1:24,000-scale, 7.5-minute maps. Latitude and longitude coordinates were determined using a global positioning system (GPS). In October 1996, with Peter Hartman, the Knutson Creek, Elbee Bluff, and Douglas Creek Localities were examined and documented from a soil science perspective. Sections at Knutson Creek and Elbee Bluff were described and additional texture samples taken. Informed consent was again granted by representatives of Theodore Roosevelt National Park and the Knife River Indian Villages National Historic Site. Locality data (e.g., location, analyses) are presented under the Study Localities section of this report.

\section{Presently Rejected Localities}

\section{Jones Creek Area}

In the Medora area, the Jones Creek drainage (or Basin E) of Hamilton (1967, Master's thesis) was examined and rejected for additional field study for this phase of the project because of the small number of paleosols. Jones Creek is in the northern tier of sections in T. 140 N., R. 101 W., in the South Unit of Theodore Roosevelt National Park, on the Fryburg NW Quadrangle in northern Billings County. Jones Creek is a west-flowing tributary of the Little Missouri River. The modern soils in the Jones Creek area were described as a Bainville loam (hilly phase), consisting of grayish brown loams and clay loams (Edwards and Ableiter, 1944). Typically, the soil occurs in dissected uplands and is generally thin, with abundant carbonates at or very near the surface. Main tributary erosion has exposed a number of 1- to 2-m cutbanks of late Holocene sediments of the Oahe Formation. One radiocarbon date indicates a record of less than 300 YBP (Hamilton, 1967). Of specific interest is Hamilton's discovery of upright stumps from which he was able to retrieve tree ring patterns. Hamilton (1967) suggested that the dendrochronology data could be used to estimate a period of climate deterioration of about 20 years in length (at about $1765 \mathrm{AD}$ ). On the basis of additional criteria, Hamilton (1967) proposed rates of deposition for the period from 1775 to 1935 . Although his values are presently difficult to confirm, a more detailed analysis of sediment banding may provide a basis upon which to interpret more detailed climate fluctuations within broader climate patterns.

\section{Little Knife Bay Area}

This short but deeply incised and complex tributary has exposed a thick section of Holocene sediments near New Town, on the north side of the Missouri River in Sections 5 and 6 of T. 152 N., R. 92 W. on the Rat Lake SE and Belden SW Quadrangles in Mountrail County. The modern soils are typical of dissected badlands. They are described as a complex of small areas of Cabba, Chambo, and Arikara soils, representing surface textures of light brownish gray 
loam, dark grayish brown clay loam, and dark grayish brown loam, respectively (VanderBusch, 1991). Soil thicknesses range from 48.3 to $78.4 \mathrm{~cm}$. Runoff from these soils is typically rapid. The Holocene strata of the Oahe Formation exposed here also reflect changes in base level associated with recent lake levels. Hamilton (1967) conducted a preliminary study of the area's erosional and depositional history. The Little Knife Bay area represented Hamilton's "Basin A." This drainage basin was used to develop a mathematical model to reflect the conditions occurring in western North Dakota that would initiate the development of channel or erosion scarps. Basin A drainage includes 2- to 3-m-high cutbanks. This area was rejected for additional field study at this time because of the few paleosols seen in examined sections.

\section{Study Localities}

\section{Knutson Creek (Localities D and M) and Fryburg (Locality C) Areas}

Recent work by Kuehn (1995, Ph.D. dissertation) developed a stratigraphic and paleoenvironmental framework for Holocene archaeological sites. The study was conducted in the Little Missouri Badlands, with special emphasis on the Holocene record preserved in the South Unit of Theodore Roosevelt National Park. Kuehn's study made numerous observations on the sedimentary record from approximately 7000 YBP to the near present. For example, Kuehn (1995) incorporated Hamilton's (1967) Jones Creek location into a larger historical context and concluded that this section is part of the latest period of terrace formation (T1) in western North Dakota. Besides the alluvial sedimentation record, Kuehn's study also involved delimiting the characteristics of slopewash, alluvial fan, and eolian deposition related to climate. The chronology of these events was established using 35 radiocarbon dates. As determined by Hamilton (1967), Kuehn (1995) recognized that dry conditions correspond to sediment transport and terrace fill deposition, and moist times correspond to reduced sediment yield and terrace incision. In June 1996, our crew studied and sampled 14 horizons on Terraces 1, 2, and 4 at Kuehn's Locality D and sampled eight horizons on Terrace 4 at Kuehn's Locality M on Knutson Creek. In October, Terrace 4 at Localities D and $\mathrm{M}$ in Billings County were sampled and described in additional detail, including sediment color (wet and dry, where possible), carbonate concentrations, root patterns, texture, and structure. Kuehn's (1995) Locality C, north of Fryburg, was briefly examined and sampled in June and further documented in October. Locality C, also in Billings County, represents a good occurrence of the Leonard Paleosol, which was collected as a possible reference for analytical methods employed in this project. The eolian loess of the Leonard Paleosol is the best-known and most frequently dated soil in North Dakota.

\section{Knife River Indian Villages Area (Elbee Bluff Locality)}

Reiten (1983) outlined the history of terrace development in the area of the Knife River Indian Villages National Historic Site in Mercer County. Reiten concluded that postglacial climatic variations were a major controlling factor in alluvial and eolian deposition. He provided an overall history of climate variation based on the sedimentary record and other evidence from approximately 10,000 YBP to the near present. Reiten recognized that based on available evidence, climatic conditions during the Holocene in western North Dakota have remained relatively dry, with periods of fluctuations between warmer and drier to cooler and moister 
conditions. In May 1996, the Knife River Indian Villages National Historic Site and confluence area of the Knife and Missouri Rivers in Mercer and McLean Counties were briefly explored for possible sites. The work of Reiten (written communication, 1996) suggested that good alluvial sections would be available in this area. Steep exposures on the east side of the Missouri River indicated that both eolian and alluvial horizons may be preserved. Subsequently, the Elbee Bluff Locality was selected for further investigation on the basis of existing section work and AMS radiocarbon dates. Terrace $A$ of the Elbee Bluff Locality was described and sampled in June, along with field-identified charcoal for possible radiocarbon dating. In October 1996, a section was described and sampled for comparison with earlier work.

\section{Emmet Area (Douglas Creek Locality)}

Short tributaries along Lake Sakakawea (of the Missouri River) frequently preserve dramatic exposures resulting, in part, from changes in base level associated with reservoir levels. The Douglas Creek Locality in McLean County had received preliminary study by John Reid in 1986 (Reid, written communication, 1995). The locality was known to contain an important succession of paleosols and is significant because the section also included possible datable charcoal at more than one horizon, datable Bison bone, and possible evidence of cultural activities. Fifteen buried soils were collected. Radiocarbon dates on Bison bone indicated the paleosols ranged in age from 5100 to 2230 YBP. In May 1996, the locality was found to have deteriorated, but remained adequate for continued study. The crew described and sampled the Douglas Creek Locality in June, with Ms. Beck conducting additional investigations and sampling into July. Additional observations on a specific interval of paleosols were made in October.

\section{Riverdale Area (Riverdale Locality)}

The Riverdale Locality represents the stratotype (type section) of the upper Pleistocene and Holocene Oahe Formation and its members. The section is located on the high cliffs along the eastern shore of Lake Sakakawea in McLean County, North Dakota. The formation and its members were formally described in Clayton and others (1976) and revised by Clayton and Moran (1979) to include sediments overlying the Pleistocene Coleharbor Formation. This definition places the sediments of this project's localities in the Oahe Formation. The stratotype, which includes the Riverdale Pick City, Aggie Brown, and Mallard Island Members, was interpreted as of largely wind-blown (eolian) origin. This section remains effectively undated by direct evidence and represents the only section where the members of the Oahe Formation can be found superposed. As the age relations of these members elsewhere in North Dakota are not well documented, in June 1996 six horizons were sampled to aid in determining the relationships of these members to our localities. A bone sample was found for possible radiocarbon dating.

\section{Meetings}

Beck, Hartman, and Reid attended the 1996 annual meeting of the Geological Society of America in Denver, Colorado. They attended symposia concerning modern and ancient climate change. Hartman met with Dr. William Zanner from the Department of Soil, Water, and Climate 
at the University of Minnesota and discussed thermal luminescence techniques in dating soil sections. Although of interest in some applications, this technique provides dates with relatively large errors and thus is not appropriate to the goals of this project. In a meeting with Dr. John Hayes, the new director of the National Ocean Sciences AMS facility, an arrangement was made to facilitate the interpretation and dating of our samples. To manage our contractual obligations and to promote the further use of NOS-AMS facility, we agreed that we would submit up to 25 carbon clast samples. These would be examined petrographically by Dr. Lorraine Eglinton, and she would choose 10 samples to be radiocarbon dated.

Beck, Hartman, and Reid participated in the annual meeting of the North Dakota Academy of Science in 1997. Beck and Hartman (1997) and Hartman (1997a) presented papers. Hartman (1997b) and Reid (1997) coordinated special symposia in response to the catastrophic flooding of the Red River of the North in April and the potentially devastating flooding of Devils Lake. Beck, Hartman, Reid, and Reiten participated in the 1997 annual meeting of the Geological Society of America in Salt Lake City, Utah (Hartman and others, 1997).

In August 1997, Hartman presented an overview of the research on this project to a review panel of the Federal Energy Technology Center of the U.S. Department of Energy, a joint sponsor of this investigation. In December 1997, Hartman met with Dr. H.E. Wright, Regents Professor Emeritus of the University of Minnesota, to discuss the results of this project. Dr. Wright has played and continues to play a major role in Quaternary research projects in Minnesota and elsewhere.

\section{METHODOLOGY (ANALYSES)}

\section{Original Methodological Considerations}

This project had three primary tasks: 1) appropriate data collection and sampling of pattern-rich Holocene sections in North Dakota, 2) analysis of samples by project staff and designated laboratories, and 3) interpretation of analyzed samples in the context of their geologic sections and in terms of a greater Holocene stratigraphic framework. The results of these tasks will provide the basis for interpretation of the climatic variations in the postglacial alluvial sedimentary record.

The primary concern in the undertaking of this work was the location and subsequent interpretation of the sedimentary record as it pertains to climate. As a direct link between alluvial process and climate appears certain, the discovery of significant paleosol patterns and the establishment of a pattern chronology are critical for the determination of periodicities and thus, cycles, that can be related to broader climate models. As noted above, study locations were selected on the basis of the presence of multiple paleosols and some previous geologic work having been done at the site.

As proposed, a chronometric framework was to be established using both radiocarbon and relative dating techniques. Isotopic techniques were to include primarily ${ }^{14} \mathrm{C}$ AMS, but possibly 
also ${ }^{210} \mathrm{~Pb}$ dating. Only radiocarbon dating methods were used. Charcoal and bone samples were sent to AMS facilities at Woods Hole Oceanographic Institution and the University of Arizona, respectively. Interpolation of cyclic patterns within dated materials would be attempted through soil chronology techniques developed by the U.S. Geological Survey (Hardin, 1982; Singer and Janitzky, 1986) and other approaches employing stable carbon analysis, magnetic induction variation (reflecting changes in sedimentation rates), cosmogenic methods, and phytolith and palynomorph analyses. Even the best geologic sections (e.g., Douglas Creek Locality) expose only $\mathrm{A}$ and $\mathrm{C}$ soil horizons, thus preventing use of soil chronology techniques. Magnetic induction, ${ }^{210} \mathrm{~Pb}$ dating, and cosmogenic methods were outside of the time and resources of the project, but are worth future consideration. Stable carbon, phytolith, and palynomorph analyses are described below. Sedimentologic work included abiotic lithosome characterization, representing, as appropriate, grain size, mineralogical, and chemical analyses. Epoxy peels of sections were not attempted, as they were considered time-prohibitive.

\section{Paleosol Studies}

Dr. Reid (written communication, 1995) has suggested two possible explanations for the sequence of buried organic horizons found at the Douglas Creek location. They represent either 1) buried organic-rich inwash layers or 2) true buried A horizons. The buried organic horizons probably represent paleosols on the basis of the following logic: The Holocene climate has remained relatively dry. Under these conditions, the materials of the A horizons were not selectively eroded, transported, and deposited because any evidence of a former organic horizon would be lost through mixing. The soils became buried as a result of a period of landform instability during which vegetative growth allowed for the development of an organic horizon. Soil development was followed by erosion of the surface higher upslope during storm events, which is related to a period of reduced precipitation in which the vegetative cover was minimal, allowing for erosion by occasional storm events. The organic-mineral couplet would thus represent a cyclic period of relatively moist and then dry climates or conditions.

\section{Incised Stream Studies}

A proposed approach to climate studies that was not attempted in this project would use incised streams. There are many ephemeral stream valleys in western North Dakota that show evidence of recent incision. These features might be studied to determine the cause and the timing of incision. Exposed buried paleosols in some of these incisions could provide datable materials, including carbonate coatings on the underside of clasts. It was suggested that thermoluminescence dating might also be feasible and that soil chronostratigraphic studies might provide relative ages of the sediments. On the basis of the results of present studies and earlier discussion with Dr. William Zanner (University of Minnesota Department of Soil, Water, and Climate), it was decided that thermoluminescence techniques would not provide sufficient temporal resolution for project objectives. Even experimentally, the cost would be prohibitive. As noted earlier, soil chronostratigraphic studies would be of limited value in a sequence of $\mathrm{Ab}$ horizons.

Although not considered feasible for the present work, this type of study might be conducted concurrently with other paleosol studies for a more complete documentation of recent 
climate change. Results from other dating techniques would provide useful background data for paleosol work. Incised stream studies might be well placed in the context of recently completed terrace development studies in western North Dakota.

\section{Alluvial Fan Studies}

Alluvial fans are frequently produced by debouching streams depositing their sediment load from a higher upstream source. Such landforms are common in western North Dakota, but tend to be relatively subdued features. The mechanics of alluvial fan formation are a widely debated topic, as are the timing and causes of their sedimentation. Alluvial fans should preserve a record of climatic history. The problem, however, is that exposures of alluvial fans are relatively uncommon in western North Dakota. The search for appropriate alluvial fans was not undertaken as part of this project primarily because of the substantial amount of additional field time and personnel required.

\section{Localities, Sections, and Sampling}

Project locality names, geologic section numbers, and other sample numbers were applied to observations throughout the project (Figure 11). Localities are reported by their general location, name, and geologic section numbers (Knutson Creek, Locality D, Section M8297). Locality names were derived from previous references or obvious geographic features. An Mnumber is applied to each distinct geologic section, observation, or collecting site. Sample numbers were typically derived from some aspect of the locality name (e.g., Locality D, Sample D-1) or as a section unit number. Table 1 summarizes the basic project label nomenclature. All locality, section, and sample information was input to computer databases designed by Hartman in Q\&A® by Symantec Corporation. Samples were collected using a trowel and small shovel and were bagged in plastic Ziploc-type bags.

\section{TABLE 1}

Locality, Section, and Sampling Nomenclature

\footnotetext{
Locality D (after Kuehn, 1995)

Section M8297 (Terrace 4), June 1996

Samples D-1-D-7

Section M8297a (Terrace 4), October 1996

Samples from Units 1-14

Section M8297b (Terrace 4), after Kuehn (1995)

Section M8311 (Terrace 2), June 1996

Samples D-13-D-14

Section M8312 (Terrace 1), June 1996

Samples D-8-D-12
}

Knutson Creek Area, Theodore Roosevelt National Park, Billings County

Continued... 
TABLE 1 (continued)

Locality M (after Kuehn, 1995)

Section M8298 (Terrace 4), June 1996

Samples M-1-M-8

Section M8298a (Terrace 4), October 1996

Samples from Units 4-15, 17-25

Section M8298b (Terrace 4), after Kuehn (1995)

Knife River Indian Villages National Historic Site, Mercer County

Elbee Bluff Locality (after Reiten, 1983)

Section M8299 (Terrace A), June 1996

Samples A-1-A-9

Section M8299a (Terrace A), October 1996

Samples from Units 1-19

Section M8299b (Terrace A), after Reiten (1983)

Douglas Creek State Game Management Area, McLean County

Douglas Creek Locality (after Reid, written communication, 1995)

Section M8301, June-July 1996

Samples DB-1-DB-13

Section M8302, June-July 1996 (primary section)

Samples DC-1-DC-9

Section M8303, June-July 1996

Samples DD-1-DD-32

Section M8304, June-July 1996

Samples DE-1-DE-8

Section M8310, October 1996

Samples from Units 1-4

Section M8313, May 1996

Samples A and B

Section M8314, 1986

Sample LS-1

Section M8315, 1986

Sample LS-2

Wolf Creek State Game Management Area, McLean County

Riverdale Locality (after Clayton and others, 1976)

Section M8300, June 1996

Samples R-1-R-5

Section M8300a (after Clayton and others 1976)

North of Fryburg Area, Theodore Roosevelt National Park, Billings County

Locality C (after Kuehn, 1995)

Section M8291

Sample C-1

Section M8291a, from Kuehn (1995) 


\section{Texture}

Sediment sample texture analysis was performed by Beck as part of her graduate program and research assistantship funded by the project using the procedure described below (Beck, 1996, unpublished report). Texture nomenclature applied to processed sediments follows the Soil Survey Manual (Soil Survey Staff, 1993), as shown in Figure 12, and texture symbols appropriate to the names used in this report are shown in Figure 13.

Approximately $45 \mathrm{~g}$ of air-dried sample was disaggregated and air-dried overnight at $100^{\circ}-110^{\circ} \mathrm{C}$. The sample was then weighed and soaked in $125 \mathrm{~mL}$ of $4 \%$ Calgon solution overnight. Distilled water was added to the Calgon-sample mixture and agitated in a sediment mixer for 1 to 2 minutes. Once thoroughly liquefied, the mixture was transferred into a settling cylinder, and distilled water was added until the volume of the mixture and water equaled $1000 \mathrm{~mL}$. This solution was then mixed in a settling tube using a plunger for approximately 45 seconds. The temperature reading taken at this point was used to determine the required settling time for sand- and silt-size particles (Perkins, 1977). Once the settling time had elapsed, usually about 2.5 hours, a hydrometer reading was taken to determine the clay content. The solution was then wet-sieved using a No. 230 sieve to remove all clay and silt from the sample. The remaining material was dried overnight at $100^{\circ} \mathrm{C}$. The gravel, coarse-, and fine-grained sand were then separated by sieving using No. 10, No. 18, and No. 230 sieves. The sieves were placed in a Ro-Tap for 10 minutes to ensure proper sorting. The sieved sands were then weighed and stored in sediment envelopes.

The gravel, coarse-, and fine-grained sand weights were determined directly through scale measurements. The amount of clay in the sample:was found by: subtracting the hydrometer value for Calgon-distilled water from the sample hydrometer reading. The amount of silt was then determined by subtracting the amount of gravel, coarse- and fine-grained sand, and clay from the original sample weight.

After the grain-size analysis was completed for each of the samples, the composition of the coarse-grained sand was examined under $10 \times$ magnification. The components of the sand were divided into four categories: lithic crystalline, quartz, sedimentary (e.g., siltstone, carbonate), and other. The roundness and general character and number of the grains in each category was then determined.

Total organic carbon analysis was attempted using loss on ignition (LOI) to serve as a proxy for organic content of Douglas Creek Locality samples (Beck, written communication, 1997). LOI was undertaken, methods reevaluated, and subsequently discontinued because the amount of organic carbon in the samples was considered likely to be very small and contamination from reworked lignite would inevitably produce erroneous results.

An air-dried raw sample was placed in a Pyrex beaker and baked at $110^{\circ} \mathrm{C}$ for a minimum of 10 hours. This temperature and time is required to remove the water of hydration. Approximately $25 \mathrm{~g}$ of sample was weighed and placed in a clean Pyrex beaker, to which $25 \mathrm{~mL}$ of $4 \%$ hydrochloric acid was added. The sample-acid mixture was agitated manually and allowed 
to settle. This step was repeated over a period of 30 minutes, allowing for the acid to interact with all of the sediment in the sample. After a few hours, or overnight, the $\mathrm{pH}$ of the mixture was measured. If the $\mathrm{pH}$ was basic, more acid was added and the previous two steps were repeated until the mixture was highly acidic. Once the mixture showed a highly acidic $\mathrm{pH}$, the filtering process began.

The following process was used to remove the halides formed by the interaction of the acid and the sediment. After the sample had been allowed to settle for a few hours, the excess liquid was poured off. This liquid was thick and yellow. The sample was then mixed with distilled water, forming a new solution. This solution was filtered using a vacuum, a thin paper filter, and a Pyrex beaker. Distilled water was poured over the sediment into the filtering system until all traces of yellow had been removed (the water ran through clear). The sample was then scraped and washed out of the filtering device and off the filter paper. Next, the sample was baked at $93^{\circ} \mathrm{C}$ until the water had evaporated from the beaker. It is important that this be done below the boiling point. This process takes 3 to 4 days of constant baking. The last 10 hours of baking was done at $110^{\circ} \mathrm{C}$ to remove the water of hydration. The sample was transferred from the Pyrex beaker to a weighing tray and immediately weighed.

Finally, the sample was spread out onto a flat beaker and placed in a furnace at $850^{\circ} \mathrm{C}$. The furnace had a good flow of oxygen through it. The sample was bumed for a minimum of 90 minutes. After removal from the furnace, the sample was placed in a desiccator until it had cooled enough to be weighed. If the total weight at this stage was not less than the total weight after the filtering process, then the sample was placed back into the furnace for periods of 30 minutes in order to determine the burning time required for these samples.

To determine the amount of carbonate lost, the weight after acid treatment/filtering was subtracted from the original weight. The total organic carbon was then calculated by subtracting the weight after burning in the furnace from the weight adjusted for lost carbonate.

\section{Radiocarbon Dating}

One of the most important concerns regarding the success of a project of this nature is finding a chronometry that can be used as a framework for the derived analytical measures. Thus, Holocene-age charcoal and bone samples were dated whenever possible. The following discussion concerns the disposition of samples for analysis, distinguishing between charcoal and lignite carbon samples, and dating methodologies.

\section{Charcoal Sample Processing}

Discussions concerning radiocarbon dating began with a meeting with Dr. Robert J. Schneider, then acting director of the WHOI NOS-AMS facility. Besides charcoal, Dr. Schneider suggested the possible carbon dating of pollen grains for use in climate studies. He offered to run preliminary samples gratis to determine the potential value of the technique with our material. Additional samples would be run at half of the usual price because of a climate incentive program supported by the National Science Foundation. The value of this technique in our studies was emphasized by Dr. Nathaniel Rutter of the Geology Department of the University of 
Alberta (verbal communication, 1996). If suitable pollen were obtained, samples of less than a milligram could be used to derive ${ }^{14} \mathrm{C}$ dates.

Samples of possible charcoal were prepared and shipped on three occasions to Drs. Robert J. Schneider and John M. Hayes, now director of the NOS-AMS facility. Of the two carbon samples sent in June to the NOS-AMS facility, Douglas Creek Sample DC-9 was dated at $3800 \pm$ 45 YBP. Thermogravimetric analysis (TGA) earlier indicated that this sample was either charcoal or lignite, and Fourier transform infrared spectroscopy (FT-IR) suggested the sample was lignite. Both samples, however, were successfully interpreted by WHOI using petrographic techniques. In a meeting in October 1996 with Dr. Hayes, the new director of the NOS-AMS facility, an agreement was made to facilitate the dating of our samples. To manage our contractual obligations and to promote the further use of the NOS-AMS facility, it was agreed that Hartman would submit up to 25 carbon samples (Table 1). These would be examined petrographically and 10 samples dated.

\section{Charcoal Versus Lignite}

Only a few small samples of charcoal were found at the Knutson Creek and Elbee Bluff localities, and a bone sample was found at the Riverdale Locality. However, charcoal appeared to be almost too common at the Douglas Creek Locality (Figure 14). The possible contamination of the paleosols by nearby reworked Paleocene-age lignite seemed a very real possibility. Thus one of the questions concerning the submission of carbon samples for dating was whether or not the samples were wood-derived charcoal or detrital lignite. This was not a simple question to resolve. Processing samples for radiometric dates is expensive. Submitting numerous samples that result in "no date". would be a waste of money.

Tests run at the EERC to distinguish charcoal from lignite produced inconclusive results. At the EERC, TGA and FT-IR were run on samples from the Elbee Bluff and Douglas Creek localities, and the samples were interpreted as most likely lignite. In TGA processing, the percentage of volatile matter was approximately equal to or exceeded the amount of fixed carbon. The $\mathrm{CO}_{2}$ and aromatic pattern of infrared absorbance (FT-IR) under increasing temperature produced results for the Douglas Creek samples also suggestive of lignite. The same techniques were used with a sample from Elbee Bluff to produce an aliphatics curve that was interpreted as either lignite or charcoal.

TGA is an analytical technique in which the weight loss of a sample is observed as a function of temperature or time-at-temperature. TGA at the EERC is conducted on a DuPont Model 951 module interfaced to a TA 2100 thermoanalyzer and data processor (R. Timpe, written communication, 1997). The instrument operates at ambient pressure or under partial vacuum and has a 100-mg sample capacity. The Model 951 has a maximum heatup rate of $100^{\circ} \mathrm{C} /$ minute, and measurements can be made at temperatures of up to about $1200^{\circ} \mathrm{C}$. The sample compartment is a quartz tube through which carrier and/or reactant gas flows from the balance housing toward the exit port. The carrier gas is normally an inert gas such as argon or nitrogen. Chemical properties of samples, e.g., combustibility, reactivity (kinetics), acidic or basic character, sorptive activity, and proximate analysis can be determined. Reactant gases are selected on the basis of the property to be studied. In addition, a special quartz tube is available 
that has a sidearm through which a 1/16-in.- (1.59-mm)-outside-diameter stainless steel tube can be inserted to allow corrosive or condensible gases to be introduced to the sample chamber without passing through the balance housing. Typical sample sizes range from 1 to $50 \mathrm{mg}$ of asreceived material. Weight, time, and temperature are computer-logged for later analysis. A table of the data and plots of sample weight, weight percent, and derivative with respect to time or temperature versus time or temperature are prepared. Typical analyses include proximate analyses, condensed gas-phase reaction kinetics, and desorption-adsorption measurements.

Characterization of carbonaceous material normally begins with a determination of moisture, volatile matter, fixed carbon, and ash (proximate analysis). Coals of bituminous and lower ranks typically have $20 \%$ to $40 \%$ (moisture-free [mf]) volatile matter. Carbonized matter will generally have a lower volatile matter content $(<5 \% \mathrm{mf})$. On this basis, it is possible to make an educated guess as to whether a particle is in its natural state or has been charred. In this project, given the choice between whether the sample was coal or wood, the volatile content was compared with the above values to make the initial judgement. Additional data on which to base a more informed choice can be obtained by analyzing the pyrolysate gas using on-line infrared (IR) spectrophotometry. IR shows that wood pyrolysates are dominated by organooxygen compounds, whereas coal pyrolysates are dominated by hydrocarbon compounds. Pyrolysates from chars may or may not give the same information, depending on extent of charring and, therefore, require close scrutiny before a decision is made.

Fortunately, distinguishing between charcoal and lignite can be accomplished by standard petrographic techniques. For this project, all carbon samples resulting in a radiocarbon date were first determined to be charcoal by analyses by WHOI (L. Eglinton, verbal communication, 1997). The basic procedure used by Eglinton followed that given by Stach and others (1982). Under reflected light at $546 \mathrm{~nm}$ (about 400x magnification), the sample is cold set in a polyester resin, ground and polished to a high standard, and examined to determine if algae, spores, or other organic structures typical of lignite are present. In addition, blue-light fluorescence can be used to distinguish charcoal from lignite: the less thermally mature the sample, the more it will luminesce. Hydrocarbon-rich lignite samples will produce lipids (e.g., spores, algae, cuticles) that will fluoresce. Thus lignite will fluoresce, while charcoal will not. In stratigraphic order, Table 2 lists all of the carbon samples submitted to WHOI for petrographic analysis and possible radiocarbon dating, and Table 3 contains the results.

\section{Radiocarbon Dating of Charcoal}

All of the dated charcoal samples were analyzed by the WHOI NOS-AMS facility. The following information was provided on how the samples were run (A.P. McNichol, written communication, 1997).

The procedure appropriate to the raw material submitted was combustion of organic carbon (OC). Carbon dioxide, whether submitted directly or generated at the NOS-AMS facility, is reacted with catalyst to form graphite. An $\mathrm{Fe}-\mathrm{H}_{2}$ catalytic reduction is used for all except very small samples, where a Co- $\mathrm{H}_{2}$ catalytic reduction is used. Graphite is pressed into targets, which are analyzed on the accelerator along with standards and process blanks. Two primary standards are used during all ${ }^{14} \mathrm{C}$ measurements: NBS Oxalic Acid I (NIST-SRM-4990) and Oxalic Acid II 
(NIST-SRM-4990C). The ${ }^{14} \mathrm{C}$ activity ratio of Oxalic Acid II $\left(\delta^{13} \mathrm{C}=-19.0\right.$ per mil) is taken to be 1.293. Every group of samples processed includes an appropriate blank, which is analyzed concurrently with the group. Process blank materials include IAEA C-1 Carrara marble for inorganic carbon and gas samples, a Johnson-Mathey $99.9999 \%$ graphite powder for organic carbon samples, and a commercial tank of ${ }^{14} \mathrm{C}$-free $\mathrm{CO}_{2}$ for seawater samples.

\section{TABLE 2}

Samples for Petrographic Processing (ordered by horizon)

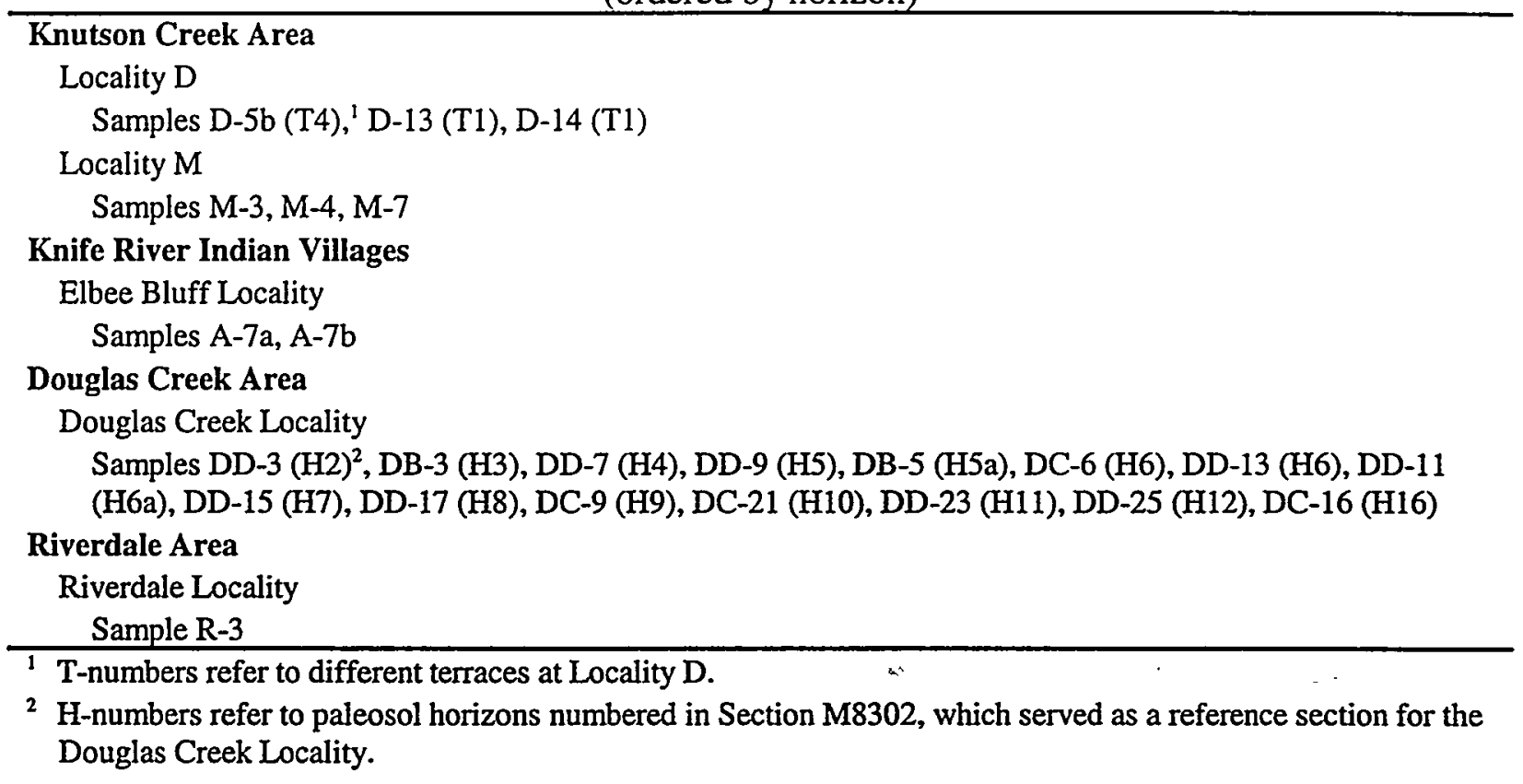

\section{TABLE 3}

Results of Petrographic Screening (ordered by sample number)

\footnotetext{
Knutson Creek Area

Locality D (Section M8297, Terrace 4)

Sample D-5b - Charcoal with $<3 \%$ mineral matter

Locality D (Section M8312, Terrace 1)

Sample D-13 - Charcoal

Sample D-14 - Charcoal

Locality M (Section M8298, Terrace 4)

Samples M-3, M-4, M-7 - All too small too analyze

\section{Knife River Indian Villages}

Elbee Bluff Locality (Section M8299)

Sample A-7a - Charcoal with about $20 \%$ mineral matter

Sample A-7b - Charcoal with about $8 \%$ mineral matter
} 
Continued ...

TABLE 3 (continued)

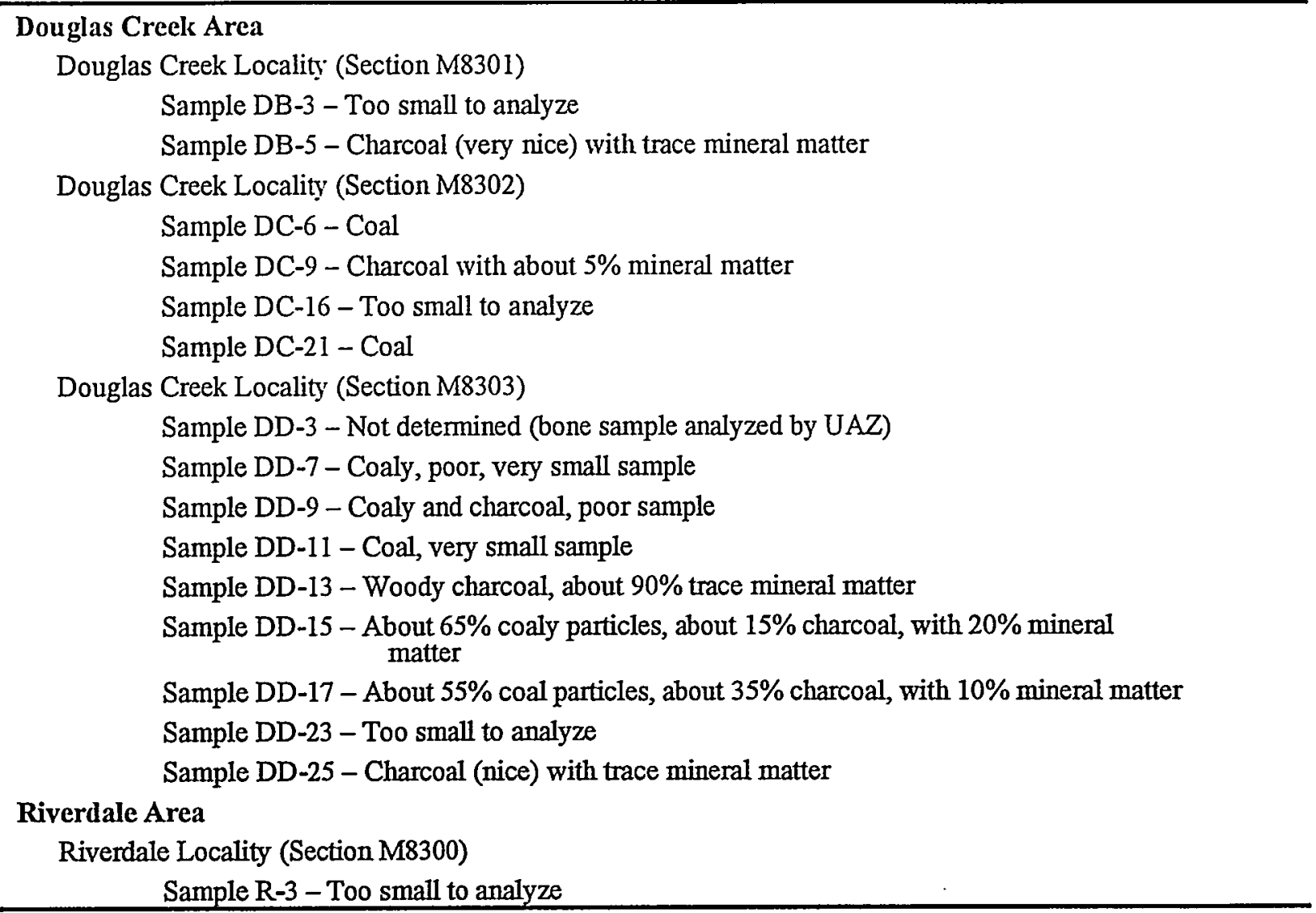

Fraction modern $(\mathrm{Fm})$ is a measurement of the deviation of the ${ }^{14} \mathrm{C}: \mathrm{C}$ ratio of a sample from "modern." Modern is defined as $95 \%$ of the radiocarbon concentration (in AD 1950) of NBS Oxalic Acid I normalized to $\delta^{13} \mathrm{C}_{\mathrm{VPDB}}=-19$ per mil (Olsson, 1970). AMS results are calculated using the internationally accepted modern value of $1.176 \pm 0.010 \times 10^{-12}$ (Karlen and others, 1968), and a final ${ }^{13} \mathrm{C}$ correction is made to normalize the sample $\mathrm{Fm}$ to a $\delta^{13} \mathrm{C}_{\mathrm{VPDB}}$ value of -25 per mil. Stable isotope measurements of sample $\delta^{13} \mathrm{C}$ used to correct $\mathrm{Fm}$ values were made at the NOS-AMS facility by analyzing subsamples of the $\mathrm{CO}_{2}$ gas generated during graphite production with a VG PRISM mass spectrometer.

Reporting of ages and/or activities follows the convention outlined by Stuiver and Polach (1977) and Stuiver (1980). Radiocarbon ages are calculated using 5568 (years) as the half-life of radiocarbon and are reported without reservoir corrections or calibration to calendar years. For nonseawater samples where $\Delta{ }^{14} \mathrm{C}$ is reported, we assume the collection and measurement dates are the same and leave it to the submitter to make further age corrections. Atoms of ${ }^{14} \mathrm{C}$ contained in a sample are directly counted using the AMS method of radiocarbon analysis; therefore, internal statistical errors are calculated using the number of counts measured from each target. An external error is calculated from the reproducibility of individual analyses for a given target. The error reported is the larger of the internal or external errors. 


\section{Radiocarbon Dating of Bone}

Bison bones were recovered from the Douglas Creek and Riverdale Localities. The following discussion concerns the techniques used in the radiocarbon dating of these materials.

In 1989, Reid submitted small samples of Bison bone from the Douglas Creek Locality for radiocarbon dating to Geochron Laboratories of Krueger Enterprises Inc. Samples LS-1 (Section M8314) and LS-2 (Section M8315) have been interpreted as corresponding to sample horizons DC-02 and DC-06 of Section M8302. A sample preparation was undertaken as described below (Geochron Laboratories, written communication, 1990).

The bone sample was thoroughly cleaned by repeated washing in distilled water under ultrasound to remove dirt and foreign material. It was then treated with dilute acetic acid to dissolve surficial carbonate materials. After washing and drying, it was crushed to fragments less than about $1 \mathrm{~mm}$ and again treated with dilute acetic acid, with periodic evacuation, until evolution of carbon dioxide from normal carbonates ceased. The powder was then washed, dried, and reacted with dilute $\mathrm{HCl}$ under vacuum to dissolve apatite and recover carbon dioxide from the apatite for analysis. The carbon yield for Samples LS-1 and LS-2 was reported as very small, about 43 and $35 \mathrm{mg}$, respectively. For Sample LS-1, the average date of readings for the last 2 of 3 days was used, the first day's readings having been interpreted as anomalously young. For Sample LS-2, the average date of 3 days of readings was used. The samples were reported as ${ }^{13} \mathrm{C}$-corrected.

As reported (Geochron Laboratories, written communication, 1990), the insoluble residue from the bone apatite dissolution procedure was filtered and washed. It was then boiled in slightly acid distilled water to solubilize any collagen present. The broth was filtered through fiberglass, and the filtrate was evaporated to dryness to recover collagen as bone gelatin. Rootlets, humic acids, and other contaminants were removed by the filter and discarded. The recovered bone gelatin was combusted, and the carbon dioxide was recovered and used for the analysis. The carbon yield for Samples LS-1 and LS-2 was reported as small, about 270 and $95 \mathrm{mg}$, respectively. For Sample LS-1, the average date for 2 days of readings was used, while the average for 3 days was used for Sample LS-2. The samples were reported as ${ }^{13} \mathrm{C}$-corrected.

AMS dates derived from bone collagen samples collected in June 1996 and submitted to the University of Arizona NSF Arizona AMS facility (UAZ). Two of four samples (DB-5a and R-7) contained insufficient collagen to calculate a radiocarbon date. The following documentation is provided by UAZ for radiocarbon dating ( $R$. Maddock, written communication, 1997). A typical sample is pretreated, converted to $\mathrm{CO}_{2}$, and reduced to graphite for analysis. The ratio of ${ }^{14} \mathrm{C} \cdot{ }^{13} \mathrm{C}$ in the graphite is measured in the accelerator and used to calculate a radiocarbon age. A conventional stable isotope mass spectrometer is available to provide $\delta^{13} \mathrm{C}$ measurements. The $\delta^{13} \mathrm{C}$ values are used to make an isotopic fractionation correction on the calculated radiocarbon ages. For samples younger than a few thousand years, the ${ }^{14} \mathrm{C} /{ }^{13} \mathrm{C}$ ratio is measured with a standard deviation of about $0.5 \%$. This precision yields an uncertainty in the radiocarbon age of approximately \pm 40 years. Published tree ring calibration curves are used to determine calendar ages. The uncertainty in the calendar age is generally larger than the uncertainty in the radiocarbon age, and depends on the location of the calculated age on the calibration curve. The 
UAZ-calibrated ages are derived with a University of Washington Radiocarbon Calibration Program, Revision 2.0 (Stuiver and Reimer, 1986).

Table 4 summarizes all of the unpublished radiocarbon dates and associated information available for project localities. Previously cited dates (e.g., Reiten, 1983) are discussed under their locality of occurrence.

\section{Stable Carbon}

Stable carbon isotope work in soils is based on different photosynthetic pathways used by plants, which produce distinctive paleoecological records. The following statements are from Boutton (1996, p. 51-54) in his review of stable carbon studies in soils. This terse account provides background information on the value of stable carbon research in paleoclimate studies and context for observations by Boutton on the results of stable carbon analysis for this project. (See also Twiss [1983] for a summary of the biological and environmental differences between $\mathrm{C}_{3}$ and $\mathrm{C}_{4}$ grasses.)

Approximately $85 \%$ of all plant species possess the $C_{3}$ pathway . . and $C_{3}$ species are dominant in most ecosystems from the boreal regions to the tropics [Figure 15]. Plants with the $\mathrm{C}_{3}$ pathway of photosynthesis have $\delta^{13} \mathrm{C}_{\mathrm{PDB}}$ values ranging from approximately $-32 \%$ to $-22 \%$, with a mean of $-27 \% 0 . . \mathrm{C}_{4}$ species comprise only about $5 \%$ of all plant species . . . and are somewhat restricted in geographic distribution. Nearly half of all $\mathrm{C}_{4}$ species are grasses of tropical and subtropical origin, and all extensive areas of $\mathrm{C}_{4}$ vegetation are grass dominated. . . $\mathrm{C}_{4}$ plants evolved from those with $\mathrm{C}_{3}$ photosynthesis between the Paleocene and Miocene and may represent an adaptation to lower atmospheric $\mathrm{CO}_{2}$ concentrations that have prevailed since the end of the Cretaceous. Anatomical and biochemical differences between $\mathrm{C}_{3}$ and $\mathrm{C}_{4}$ species result in more efficient photosynthesis by $\mathrm{C}_{4}$ species when atmospheric $\mathrm{CO}_{2}$ concentration is relatively low. Thus, the relative productivity and geographic distribution of $\mathrm{C}_{4}$ species since the Paleocene have probably been influenced not only by climatic variation but also by fluctuations in atmospheric $\mathrm{CO}_{2}$ concentrations. . . $\mathrm{C}_{4}$ plants have $\delta^{13} C_{\mathrm{PDB}}$ values ranging from approximately $-16 \%$ to $-9 \%$, with a mean of $-13 \%$, Thus, the ranges of $\delta^{13} \mathrm{C}_{\mathrm{PDB}}$ values reported for $\mathrm{C}_{3}$ and $\mathrm{C}_{4}$ plants a not overlap (Boutton, 1996).

Fluctuations in stable carbon reflect relatively well the variation in temperature during the Holocene noted by Folland and others (1991) (Figure 16).

Sediment samples from 40 horizons from project localities were specifically collected for stable carbon isotope $\left(\delta^{13} \mathrm{C}\right)$ analysis and processed by Dr. Thomas Boutton at the Texas A\&M University Stable Carbon Isotope Laboratory. A list of the results is given in Table 5. Stable carbon analysis methods were described by Boutton (1996, p. 49) as follows: Organic matter is quantitatively converted to $\mathrm{CO}_{2}$ by combustion at $\sim 900^{\circ} \mathrm{C}$ in an $\mathrm{O}_{2}$ atmosphere. The $\mathrm{CO}_{2}$ is isolated and purified by cryogenic distillation or gas chromatography, and the isotopic composition of the $\mathrm{CO}_{2}$ is determined by simultaneous collection of masses $44\left({ }^{12} \mathrm{C}^{16} \mathrm{O}^{16} \mathrm{O}\right)$, $45\left({ }^{13} \mathrm{C}^{16} \mathrm{O}^{16} \mathrm{O}\right)$, and $46\left({ }^{12} \mathrm{C}^{18} \mathrm{O}^{16} \mathrm{O}\right)$ in a mass spectrometer equipped with three ion-beam collectors. The isotopic composition of $\mathrm{CO}_{2}$ from the sample is compared to that derived from a standard with a known ${ }^{13} \mathrm{C}:{ }^{12} \mathrm{C}$ ratio. 


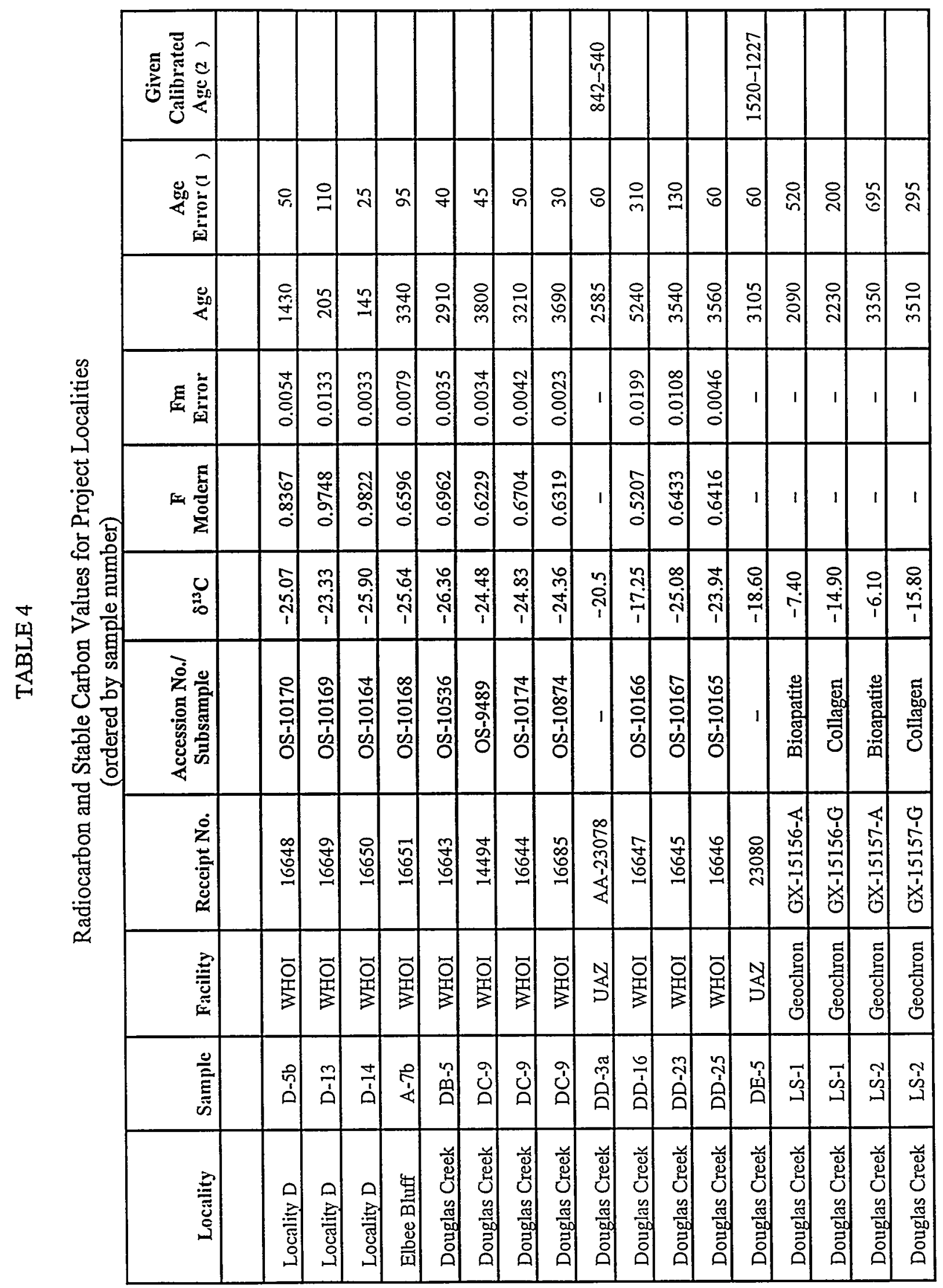


TABLE 5

Stable Carbon Values $-\delta^{13} \mathrm{C}_{\mathrm{PDB}}(\%)$ (Boutton)

\begin{tabular}{|c|c|c|}
\hline \multicolumn{3}{|c|}{ Knutson Creek Area } \\
\hline \multicolumn{3}{|c|}{ Locality D (Section M8297, Terrace 4) } \\
\hline Sample D-02 & -21.62 & Boutton ND17 \\
\hline Sample D-04 & -23.63 & Boutton ND18 \\
\hline Sample D-06 & -24.43 & Boutton ND19 \\
\hline Sample D-07 & -23.20 & Boutton ND20 \\
\hline \multicolumn{3}{|c|}{ Locality D (Section M8311, Terrace 2) } \\
\hline Sample D-08 & -24.56 & Boutton ND21 \\
\hline Sample D-09 & -23.92 & Boutton ND22 \\
\hline Sample D-10 & -24.80 & Boutton ND23 \\
\hline \multicolumn{3}{|c|}{ Locality D (Section M8312, Terrace 1) } \\
\hline Sample D-13 & -24.78 & Boutton ND24 \\
\hline Sample D-14 & -24.50 & Boutton ND25 \\
\hline \multicolumn{3}{|c|}{ Locality M (Section M8298) } \\
\hline Sample M-01 & -18.70 & Boutton ND13 \\
\hline Sample M-08 & -22.82 & Boutton ND16 \\
\hline Sample M-05 & -23.04 & Boutton ND14 \\
\hline Sample M-07 & -23.03 & Boutton ND15 \\
\hline \multicolumn{3}{|c|}{ Knife River Indian Villages } \\
\hline \multicolumn{3}{|c|}{ Elbee Bluff Locality (Section M8299) } \\
\hline Sample A-03 & -21.16 & Boutton ND07 \\
\hline Sample A-04 & -22.71 & Boutton ND08 \\
\hline Sample A-05 & -22.48 & Boutton ND09 \\
\hline Sample A-06 & -22.90 & Boutton ND10 \\
\hline Sample A-07 & -23.98 & Boutton ND11 \\
\hline Sample A-09 & -23.72 & Boutton ND12 \\
\hline \multicolumn{3}{|c|}{ Douglas Creek Area } \\
\hline \multicolumn{3}{|c|}{ Douglas Creek Locality (Section M8302) } \\
\hline Sample DC-02 & -20.40 & Boutton ND26 \\
\hline Sample DC-03 & -19.59 & Boutton ND27 \\
\hline Sample DC-04 & -21.94 & Boutton ND28 \\
\hline Sample DC-05 & -22.04 & Boutton ND29 \\
\hline Sample DC-06 & -23.46 & Boutton ND30 \\
\hline Sample DC-07 & -23.69 & Boutton ND31 \\
\hline Sample DC-08 & -22.90 & Boutton ND32 \\
\hline Sample DC-09 & -22.74 & Boutton ND33 \\
\hline Sample DC-10 & -22.65 & Boutton ND34 \\
\hline Sample DC-11 & -21.65 & Boutton ND35 \\
\hline
\end{tabular}

Continued ... 
TABLE 5 (continued)

\begin{tabular}{ccc}
\hline Sample DC-11 & -22.24 & Boutton ND36 \\
Sample DC-13 & -22.00 & Boutton ND37 \\
Sample DC-14 & -22.64 & Boutton ND38 \\
Sample DC-15 & -22.98 & Boutton ND39 \\
Sample DC-16 & -22.80 & Boutton ND40 \\
Riverdale Area & & \\
Riverdale Locality (Section M8300) \\
Sample R-1 & -19.59 & Boutton ND01 \\
Sample R-2 & -19.94 & Boutton ND02 \\
Sample R-3 & -21.18 & Boutton ND03 \\
Sample R-4 & -20.96 & Boutton ND04 \\
Sample R-5 & -22.07 & Boutton ND05 \\
Sample R-6 & -23.33 & Boutton ND06 \\
\hline
\end{tabular}

\section{Palynomorphs}

Palynomorph studies can provide valuable information on the change in vegetation patterns through time (e.g., Figure 17). Changes in the abundance of grasses, shrubs, and trees or changes in specific assemblages indicate changes in climatic conditions.

Samples for palynomorph analysis and possible AMS dating were collected by the field crews in June and October 1996 and processed by Dr. Timothy Kroeger (Bemidji State University) at the EERC. Examples of palynomorphs recovered from project localities are illustrated in Figure 18.

Palynological maceration methods follow those given by Doher (1980), Traverse (1988), and Kroeger (1995; 1996, unpublished report). As reported by Kroeger (1995, p. 15; 1996, unpublished report), palynomorph-bearing residues were extracted from 40 sediment samples. Samples were trimmed to remove potential surface contaminants. About $1 \mathrm{~cm}^{3}$ of rock was crushed with a mortar and pestle, and the crushed rock was placed in polypropylene centrifuge tubes for acid maceration. Mineral matter was removed by treating with an excess of $52 \%$ hydrofluoric acid followed by repeated water washes. Where necessary, samples were treated for 10 minutes in Schulze's solution. Humic debris was removed by boiling for 5 to 10 minutes in $5 \%$ potassium hydroxide or Calgon followed by repeated washes of hot water. Any remaining mineral matter was removed by density separation using zinc chloride with a specific gravity of 2.0 centrifuged at $2000 \mathrm{rpm}$ for 90 minutes. Finely divided organic material and remaining clays were removed from the samples by short centrifuging or gravity-settling methods. Filtration through nylon screens was not used on samples intended for quantitative analysis. Large organic fragments were removed from coal and carbonaceous shale samples by screening with a $125-\mu \mathrm{m}$ brass screen. The coarse residues were scanned with a binocular microscope, and megaspores and other microfossils were picked and mounted for possible future study. 
The results reported here are considered preliminary in that the opportunities to use palynomorphs successfully in a study of this type have not been exhausted. The purpose of sediment sampling for palynomorph examination was twofold - to determine whether palynomorphs were sufficiently well preserved for identification and environmental interpretation and to determine whether they occurred in sufficient abundance to be used as a carbon source for radiocarbon dating. Palynomorphs were present and sometimes relatively abundant in some samples, but they frequently were poorly preserved and, more importantly, likely to have been reworked from nearby Paleocene sediments. Once fossilized, Paleocene palynomorphs are rather indestructible, especially compared to Holocene palynomorphs occurring under the highly oxidized conditions of Holocene soils in the northern Great Plains. The following conclusions were excerpted from Kroeger (written communication, 1997).

All samples have a considerable amount of carbonized plant debris, amorphous organic detritus, and/or cuticle material. This organic material is probably dominant in every sample. It would probably be impossible to get most of this material out of the samples, as most of it is about the same size as the pollen grains. Some samples are interpreted to have modern rootlets, but we could probably filter them out since they are relatively large.

Most samples have specimens of what are believed to be soil-dwelling fungal remains. Kroeger has not seen these described in the literature, but modern fungal studies are outside his area of expertise. In any case, they may represent organisms that were growing considerably later than the date that the sediment was deposited. The same forms have been seen in ancient samples that were collected from the soil zone.

None of the samples have what could be interpreted as a complete, diverse palynomorph assemblage. In general, most Quaternary pollen represent plants like ragweed, sage, and the chenopods and amaranths. Very little grass pollen is present. Pine pollen is generally quite common, but most is similar to a species of pinelike pollen that is found in the Paleocene; it is uncertain whether or not they are reworked.

There are numerous samples that do not show evidence of contamination, but then they have very little pollen. These samples do have plenty of organic material, but it is not possible to have determine whether it was reworked from the lignites. In general, carbonized plant debris is more resistant to degradation than pollen and spores are, especially if charcoal is involved. The samples listed in Table 6 may provide the best results.

The above data suggest that palynomorphs are particularly hard won from short-duration soils (Ab horizons) and highly oxidized sediments between soils in alluvial deposits of Quaternary age. Without more abundant palynomorphs, separation of them from other organic material is difficult, and the use of palynomorphs for radiocarbon dating remains unlikely. Without diverse palynomorph assemblages in any given geologic section, palynomorphs will be of little value in directly interpreting climate change in alluvial environments. 


\section{TABLE 6}

Palynomorph Annotations for Project Localities

(see Figure 18 for selected taxa)

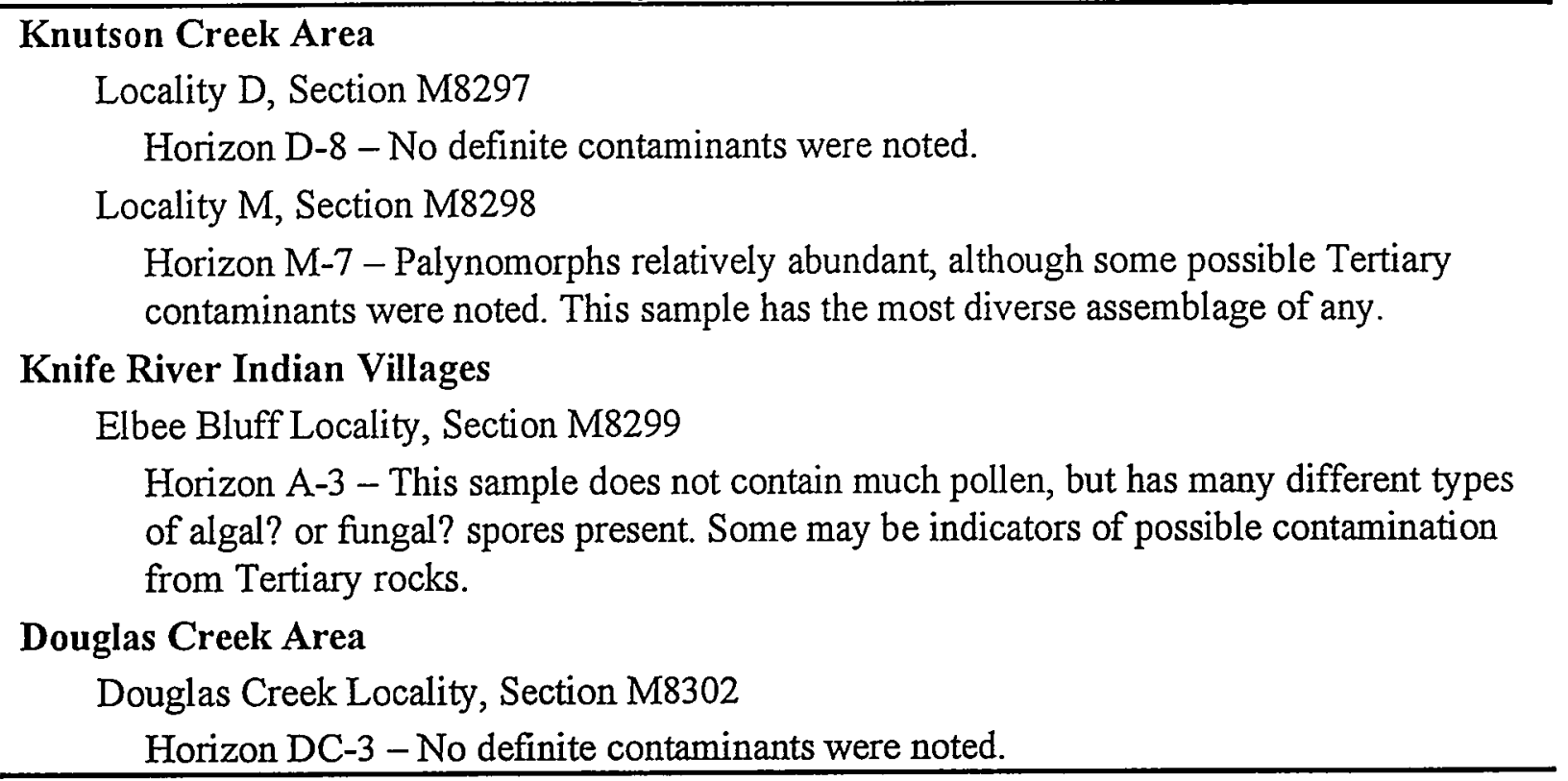

\section{Phytoliths}

Phytoliths are siliceous shapes that form within and between cells in plants by precipitation of hydrated silica acquired from percolating groundwater (Figure 19). Phytoliths form mainly in grasses and are thus becoming more popular for reconstructing grassland environments. Mesic tall, xeric short, and cool season grasses can be distinguished on the basis of phytolith morphology. In addition, $\mathrm{C}_{3}$ and $\mathrm{C}_{4}$ types can be distinguished. Typically, moisture and temperature conditions present during phytolith formation can be inferred from the dominance of either $\mathrm{C}_{3}$ or $\mathrm{C}_{4}$ plants. Thus, variation in the composition of phytolith assemblages in adjacent paleosols may indicate climate change.

Sediment samples for phytolith analysis were processed by Dr. Glen Fredlund of the University of Wisconsin-Milwaukee. As reported by Fredlund (1997, unpublished report), extraction of phytoliths is undertaken as follows: 1) oxidation of carbonates with $\mathrm{HCl}, 2$ ) dispersal and removal of clays and organic colloids with $0.1 \mathrm{~N}$ sodium pyrophosphate, 3) oxidation of remaining organics with $30 \%$ hydrogen peroxide, and 4) isolation of biogenic silicates with heavyliquid flotation $\left(\mathrm{ZnBr}_{2}\right.$ at 2.35 specific gravity). The isolated fraction is then dried, weighed, and microscopically analyzed. The extracted weight for each sample is expressed as a percentage of the original sample weight. The percent of biogenic opal in the isolated fraction was estimated using a rapid point count under 400× magnification. Fredlund used a 6-point scale to describe phytolith preservation (Table 7, Figure 20). He stated that although somewhat subjective, this procedure provides a consistent basis for comparing samples. Preservation of 2 or below on this scale suggests the potential for differential preservation, precluding analysis of grass assemblages. Thus phytolith morphologies of Samples A2 and 


\section{TABLE 7}

Phytoliths from Project Localities

(ordered by sample number)

\begin{tabular}{|c|c|c|c|c|c|c|c|c|c|c|c|c|c|}
\hline Sample & GGF ID & $\mathbf{P}^{2}$ & Keeled & Rondel. & Rect. & Crenate & Stipa. & Saddles & Bilobate & Panicoid & Lobatest $^{3}$ & SUM & n \\
\hline \multicolumn{14}{|c|}{ Elbee Bluff Locality, Section M8299 } \\
\hline A-03 & 96082007 & 4 & 10.840 & 26.600 & 3.450 & 3.450 & 4.430 & 43.840 & 2.950 & 2.950 & 0.980 & 99.490 & 205 \\
\hline \multicolumn{14}{|c|}{ Douglas Creek Locality, Section M8302 } \\
\hline DC-02 & 96092601 & 5 & 16.200 & 44.440 & 3.700 & 3.700 & 2.310 & 26.390 & 2.310 & 0.460 & 0.460 & 99.970 & 218 \\
\hline DC-03 & 96092602 & 4 & 12.690 & 34.010 & 5.070 & 4.060 & 4.570 & 34.010 & 3.050 & 2.540 & 0.500 & 100.500 & 197 \\
\hline DC-04 & 96092603 & 4 & 14.029 & 41.590 & 3.270 & 3.270 & 2.800 & 29.440 & 2.800 & 2.800 & 0.000 & 99.999 & 215 \\
\hline DC-06 & 96092605 & 4 & 14.810 & 33.330 & 4.940 & 2.470 & 3.090 & 37.040 & 3.090 & 0.930 & 0.310 & 00.010 & 325 \\
\hline DC-07 & 96092606 & 4 & 10.380 & 41.150 & 3.850 & 5.770 & 3.080 & 31.150 & 2.310 & 1.540 & 0.770 & 00.000 & 260 \\
\hline DC-08 & 96092607 & 4 & 11.830 & 30.920 & 3.820 & 7.250 & 3.820 & 35.880 & 2.290 & 3.810 & 0.380 & 00.000 & 262 \\
\hline DC-09 & 96092608 & 4 & 13.910 & 33.140 & 3.550 & 6.800 & 6.800 & 29.590 & 3.840 & 1.780 & 0.590 & 00.000 & 341 \\
\hline DC-10 & 96092609 & 4 & 10.990 & 37.800 & 5.150 & 3.440 & 3.780 & 34.020 & 2.400 & 1.370 & 1.030 & 99.980 & 293 \\
\hline DC-11 & 96092610 & 4 & 12.440 & 42.580 & 3.830 & 6.220 & 2.390 & 27.270 & 1.430 & 2.870 & 0.950 & 99.980 & 211 \\
\hline DC- 13 & 96092612 & 4 & 19.640 & 33.040 & 4.460 & 3.135 & 4.020 & 31.690 & 2.230 & 1.340 & 0.890 & 00.445 & 226 \\
\hline DC-14 & 96120402 & 4 & 13.460 & 40.870 & 3.370 & 3.370 & 2.400 & 30.290 & 2.880 & 1.920 & 2.400 & 00.960 & 208 \\
\hline DC-15 & 96120403 & 4 & 13.840 & 37.950 & 4.460 & 4.020 & 3.570 & 28.570 & 4.460 & 2.230 & 0.890 & 99.990 & 227 \\
\hline DC-16 & 96120404 & 4 & 11.740 & 32.960 & 5.590 & 2.230 & 5.590 & 34.640 & 5.030 & 2.230 & 0.000 & 00.010 & 179 \\
\hline \multicolumn{14}{|c|}{ Riverdale Locality, Section M8300 } \\
\hline $\mathrm{R}-2$ & 96082001 & 4 & 17.870 & 39.610 & 3.860 & 2.890 & 3.860 & 28.990 & 1.937 & 0.480 & 0.480 & 99.977 & 209 \\
\hline $\mathrm{R}-3$ & 96082002 & 5 & 14.140 & 45.550 & 4.710 & 2.620 & 5.240 & 23.560 & 2.620 & 1.570 & 0.000 & 00.010 & 191 \\
\hline
\end{tabular}

${ }^{1}$ Fredlund identification number (written communication, 1997).

${ }^{2}$ Preservation scale of evaluation; $5=$ excellent, $4=$ good.

3 Other lobates. 
A4-A9 from the Elbee Bluff Locality and R4-R6 from the Riverdale Locality were not tabulated because of general low abundance. The classification of phytoliths was conducted using transmitted light microscopy at a magnification of 400-1000×. For this project, a minimum of 200 grass short-cell phytoliths were counted per sample.

Beck (1997, unpublished report) performed cluster and factor analyses on phytolith assemblages to determine the similarities between paleosols (Figure 21). The following discussion presents the results of her study. Cluster analysis was performed using the program UPGMA (R.D. LeFever, University of North Dakota Department of Geology and Geological Sciences). Raw nonstandardized and standardized data were entered and dendrograms created using unweighted clustering calculated by distance. The first attempts produced cophenetic coefficients (CC) that were below 0.8 (e.g., $\mathrm{CC}=0.713$ and 0.621 , respectively). Such values indicate uncertainty in the data and should not be considered conclusive. A second analysis determined the $\log$ ratio of each data value with respect to the panicoid morphotype. The $C C$ values for these were 0.979 and 0.737 for the nonstandardized and standardized data, respectively. Of the four cluster analyses, only the nonstandardized log-ratio data resulted in a $\mathrm{CC}$ value large enough to be considered potentially significant. A dendrogram with three distinct paleosol clusters resulted (Figure 18). The first cluster (A) consisted of Paleosols 10, 13, 7, 12, 11, 14, 8, 9, 15, 5, and 3. The second group contains Soils 2 and 6 (B), and the last included Soils 4 and 16 (C). Any relationship between phytolith assemblages and the results of the other analyses such as stable carbon and texture are difficult to deduce from this dendrogram.

Factor analysis was performed using the program FACTOR (R.D. LeFever, University of North Dakota Department of Geology and Geological Sciences), which calculated eigenvectors, eigenvalues, and factor scores. The analysis was run using $\mathrm{R}$-mode, with a correlation coefficient matrix retaining two factors of rotation. This resulted in $97.29 \%$ of the total variance being explained by the first three variables. This same format was then run with the log-ratio values for the panicoid morphotype. This analysis resulted in $98.37 \%$ of the variance being explained by the first three variables. The factor scores for Factors 1 and 2 were plotted against one another for each observation for initial and log-ratio analyses. These plots were intended to group the most similar horizons together. However, for both data sets, the factor scores plotted randomly as one large mass. Small clusters within this plot seem to have little meaning.

Possible factors that could have affected the results of this analysis include winnowing of phytoliths or relative percentages of each morphotype. Winnowing is a likely possibility in that the Douglas Creek Locality section represents a valley fill with associated local uplands. Texture analysis suggests that this area experienced periodic influxes of sediment and increased flow regimes (see Douglas Creek Locality, p. 57) and thus the means and the mode that could result in winnowing and redeposition of phytoliths. Possibly, assemblages of different ages and environments occurred. Of importance, however, are the relative percentages of phytolith morphologies. Small variations in the percent of panicoid-type phytoliths are likely more significant than even larger variations in the more common morphotypes. More study of the phytolith abundance and assemblage composition is necessary to properly evaluate the utility of phytoliths in alluvial paleosol studies (Beck, 1997, unpublished report). 


\section{Mollusks}

Pulmonate mollusks recovered from the Knutson Creek and Elbee Bluff Localities that were identified by Hartman are listed taxonomically in Table 8; examples are illustrated in Figure 22. Locality documentation and information on the age and ecology of the species are given in Tables 9 and 10. Aquatic (basommatophoran) and terrestrial (stylommatophoran) pulmonates were identified using comparative collections at the Field Museum and distribution and illustrations in Cvancara (1983), Hubricht (1985), and other sources mentioned below. The Knutson Creek Locality taxa consist of the terrestrial (air-breathing) species, Succinea indiana and Pupilla muscorum, which are tentatively identified for the purposes of this project. Together, these species indicate a dry environment, possibly on relatively open ground or with limited vegetation. These conditions are similar to or possibly less favorable than presently found in this area and consistent with upland terrain in the general headwaters area of Knutson Creek. This report of $S$. indiana from about or slightly older than $6115 \pm 145 \mathrm{YBP}$ is thought to be its first subfossil report.

In contrast, the pulmonate fauna reported from the Elbee Bluff Locality include only aquatic (gill-bearing) taxa common to generally permanent or intermittent lake, pond, or stream environments. These conditions probably prevailed during the deposition of the lower portion of the section at Elbee Bluff from about 4000 to $3000 \mathrm{YBP}$. This interval corresponds to the most negative stable carbon values representing cool and moist conditions. This report of Gyraulus circumstriatus from about $2974 \pm 66 \mathrm{YBP}$ is thought to be its first subfossil report.

\section{Paleosol Ages at the Douglas Creek Locality}

\section{Calculating Paleosol Ages (interpolating time)}

The calculation of interpolated paleosol ages was accomplished by utilizing radiocarbon dates acquired as a result of this project (Figure 23). The Douglas Creek Locality Section M8302 is used here as a composite example of all of the paleosols. Section M8302 was divided into six intervals, each delimited by two known dates (Table 11). These two dates (Table 11, Column 2) were then used to determine the formation time for only those paleosols formed between them as described below.

To derive the total thickness of an interval, the thicknesses $(\mathrm{cm})$ of the delimited buried soil horizons are added together. The thickness of the intervening unaltered units $(\mathcal{C}$ horizon) is ignored because of their proposed rapid (effectively instantaneous) deposition. Next, the thicknesses of the two confining units (those with ${ }^{14} \mathrm{C}$ dates) are added and their sum divided by 2 to get the total thickness for the two confining units (Table 11, Column 3). Only half of their total thickness is used because the radiocarbon age of the paleosol units is an average age. Therefore, only half of their formation is believed to have taken place during the time before or after the derived date. The total thickness for the interval is determined by adding the thickness calculated for the delimited units and the thickness determined for the confining units. 
TABLE 8

Pulmonate Mollusks from Project Localities ${ }^{1}$

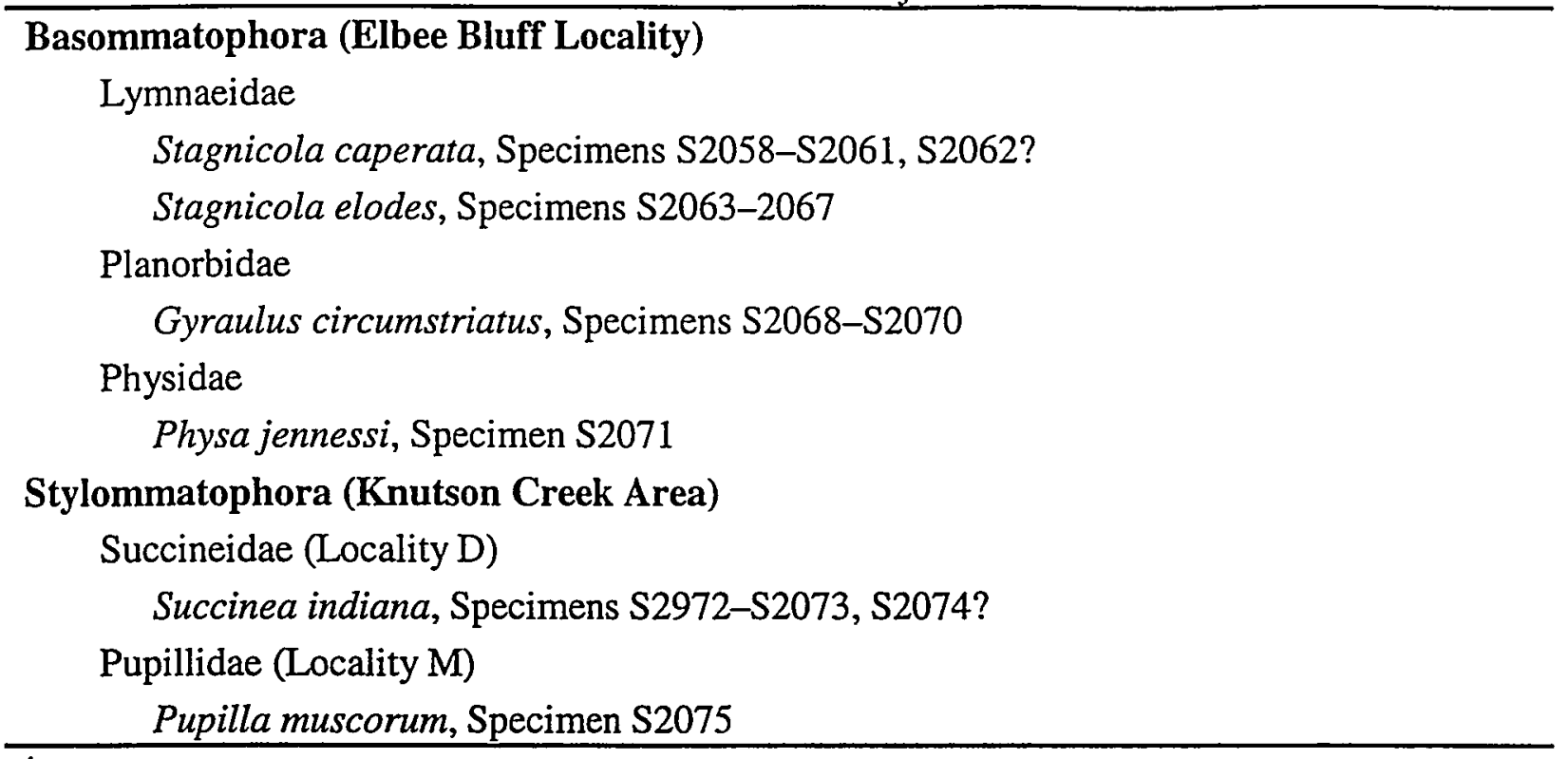

${ }^{1} S$-numbers in Table 8 refer to a molluscan numbering system used by Hartman.

\section{TABLE 9}

Molluscan Specimen Documentation

\section{Theodore Roosevelt National Park; badlands terrain}

\section{Locality D}

Section M8297c, Sample Unit 2 of Kuehn's (1995) section of Locality D, range

2.4-3.4 $\mathrm{m}$ below top of Terrace 4

Sample probably slightly older than $6115 \pm 145$ YBP [D-a]

Specimens S2072 and S2074

Collected 6/19/96 by Reiten (Hartman, Trip 96f, v. II, p. 100)

Section M8311, Sample D-12, range 53-68 cm below top of Terrace 2

Sample older than $145 \pm 25$ and younger than $1430 \pm 50$ YBP [D-b]

Specimen S2073

Collected 6/19/96 by Hartman (Trip 96f, v. II, p. 106, 107)

Theodore Roosevelt National Park, badlands terrain

Locality $\mathrm{M}$

Section M8298, Sample M-2, paleosol, range $28-30 \mathrm{~cm}$ below top of Terrace 4

Sample younger than $1430 \pm 50$ YBP $[\mathrm{M}]$

Collected 6/19/96 by Hartman (Trip 96f, v. II, p. 111, 115)

Specimen S2075

Continued... 
TABLE 9 (continued)

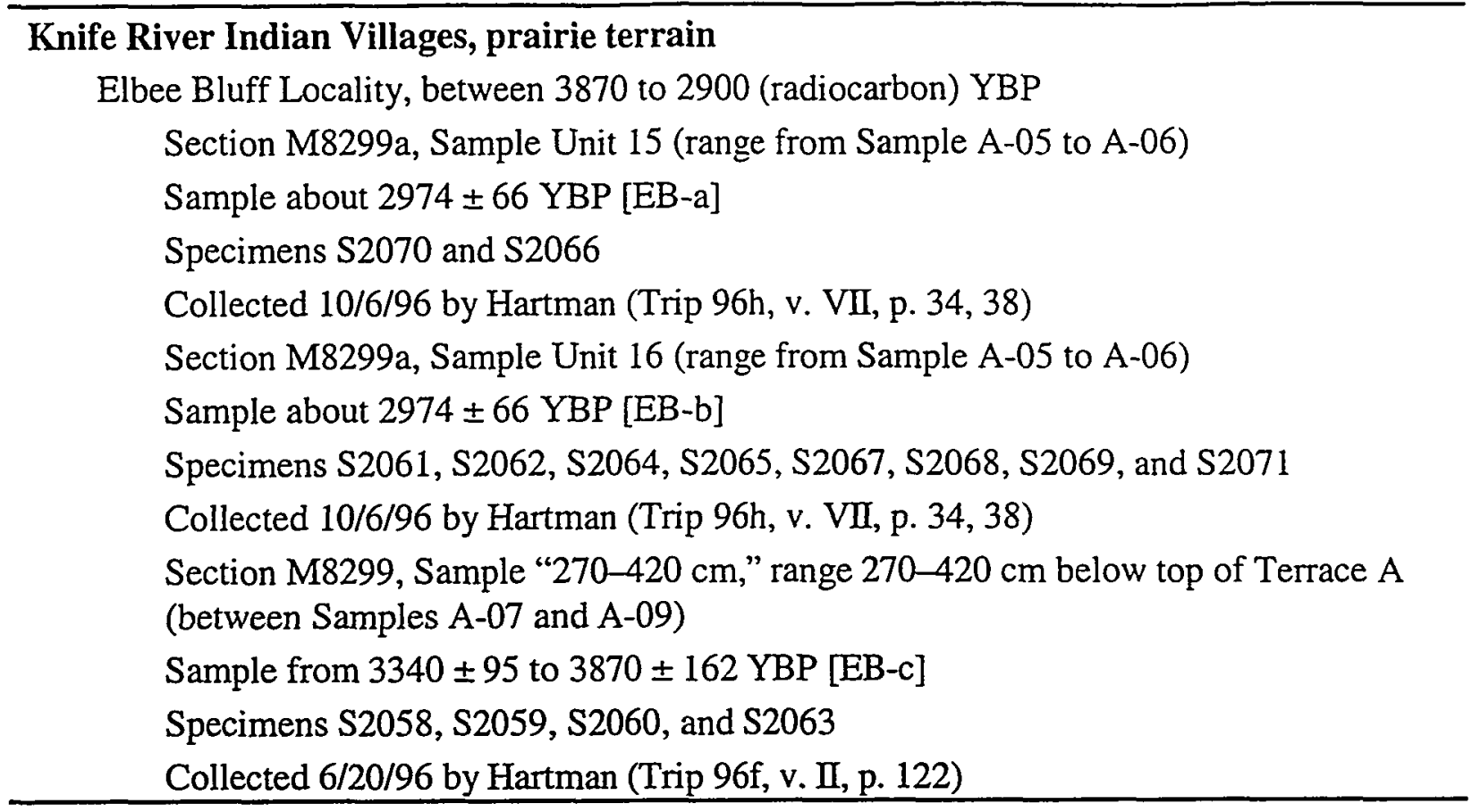

To determine the total amount of time between two known dates (in years), subtract the younger from the older age (Table 3, Column 2). Divide the total time by the total thickness. This calculates the rate of soil formation in years per centimeter (Table 11, Column 4). Multiply the thickness of the individual soil horizons by this factor to determine the total time of formation for each paleosol (Table 11, Column 5). Again, only one-half the thickness should be used for the confining units. In order to determine the average age of each paleosol, the known date for the youngest delimited unit is added to half of the total time of formation for the first confining unit plus half of the formation time for the first unknown paleosol (Table 11, Column 6). The dates of the remaining paleosols within this interval can be determined by adding the second half of the paleosol formation time for the previous paleosol, the calculated age of the previous paleosol, and half of the total formation time for the desired paleosol. This process is continued until an age has been calculated for each of the paleosols confined by the two dated ones. This process is followed for each interval of the section.

The interpolated dates of paleosols were similarly derived using Section M8303 as the composite section (Table 12). The last paleosol of Section M8302, which includes an older paleosol not exposed elsewhere, was added to M8303 for comparability. The paleosols lateral to Section M8302 thin, decreasing their inferred rate of development.

The total time (excluding radiocarbon dating analytical errors) between Paleosols 2 and 16 is 2655 radiocarbon years, with a total paleosol thickness of $125.5 \mathrm{~cm}$. This equals a general rate of 21.15 years $/ \mathrm{cm}$ for paleosol development for Section M8302. This value is in contrast to 42.14 years $/ \mathrm{cm}$ for the $63 \mathrm{~cm}$ of paleosols in Section M8303. 


\title{
TABLE 10
}

\section{Pulmonate Age and Modern Ecology}

\author{
Taxa from Knutson Creek Localities \\ Locality D \\ Succinea indiana, Specimens S2972-S2073, S2074? \\ Age - Prior to this study, this taxon was known with certainty only from the present \\ (LaRocque, 1970) \\ Modern ecology - This species has been reported as "usually ... in rather dry, sunny \\ situations on bare ground" (Hubricht, 1985). \\ Taxonomy - Pilsbry $(1948$, p. 817$)$ stated that "Succinea indiana . . . appears to be a \\ rather full form of aurea, more coarsely and irregularly striate, and somewhat more \\ globose in form; possibly a subspecies" (Pilsbry, 1948, p. 817). As with many \\ pulmonates, specimens of Succinea are very difficult to identify without soft anatomy. \\ Specimens assigned to this taxon were sent to Dr. Dorothea Franzen, a succineid \\ specialist, for study. \\ Locality $\mathrm{M}$ \\ Pupilla muscorum (M), Specimen S2075 \\ Age - The North American age range of this taxon was reported as middle Pliocene to \\ Holocene (Hibbard and Taylor, 1960). \\ Modern ecology - In England this species has been reported from "dry exposed calcareous \\ places: screes, stone walls, short-tufted grassland; characteristic of coastal dunes" (Kerney \\ and Cameron, 1994, p. 91); in the eastern United States it is a "calciphile ... of grassy \\ roadsides and meadows" (Hubricht, 1985); and was reported by LaRocque (1970, p. 732) as \\ "especially abundant in rocky areas such as limestone quarries and escarpments, under \\ limestone slabs with accumulation of rock powder and soil, and in joints and fissures of \\ rocks."

\section{Taxa from the Elbee Bluff Locality} \\ Stagnicola caperata, Specimens S2058-S2061, S2062? \\ Age - The age range of this taxon was reported as middle Pliocene to Holocene (Hibbard and \\ Taylor, 1960), with a North Dakota Holocene record of 8000-4000 YBP to the present \\ (Cvancara, 1976). \\ Modern ecology - Cvancara (1983) reported that this species seems to prefer stagnant, \\ nonflowing water bodies. In North Dakota, specimens were found predominantly in \\ permanent pond, lake, or small stream settings, with rare occurrences in intermittent pond or \\ lake conditions. However, Cvancara (1983, p. 67) states that "this species has been \\ reported largely from seasonal water bodies (intermittent lakes, ponds, and streams), as well \\ as from flooded or marginal parts of perennial water bodies that become dry for part of the \\ year (Clarke, 1973, p. 315-316). This agrees closely for the occurrences in North Dakota. \\ Although there were 10 permanent lake or pond localities ... for the species, it occurred \\ specifically along margins of these water bodies that presumably become dry periodically. \\ Channel widths $(n=5)$ were $17-37 \mathrm{~m}$ (mean $=28 \pm 8 \mathrm{SD}$ ). This species tolerated waters of \\ high specific conductance ...S. caperata was most frequently associated with Physa \\ jennessi and Promenetus exacuous, and is part of the Aplexa hypnorum-Gyraulus \\ circumstriatus Association." \\ Stagnicola elodes, Specimens S2063-2067 \\ Age - The age range of this taxon was reported as early Pleistocene to Holocene (Baker, 1920), \\ with a North Dakota Holocene record of at least about 12,000-8000 YBP to the present \\ (Cvancara, 1976).
}


TABLE 10 (continued)

Modern ecology - This species has been reported from large and small lakes, permanent and intermittent ponds, swamps, and large and small streams (Cvancara, 1983). Clarke (1979) reported that this species is characteristic of mesotrophic and eutrophic lakes. In North Dakota, specimens occurred predominantly in permanent pond, lake. or small stream settings. with common occurrences in intermittent pond, lake, or stream conditions. "In North Dakota, [S. elodes] ... was collected from all habitats except large streams. Channel widths $(n=11)$ were 3-37 [m] (mean $=16 \pm 14 \mathrm{SD}$ ). This species tolerated high values of total chlorides and extremely high values of total sulfates. In New York, Harman (1972) found decaying. terrestrial plant matter to be the preferred substrate. $S$. elodes was most frequently associated with Helisoma trivolvis, and is part of the H. trivolvis-Lymnaea stagnalis Association" (Cvancara, 1983, p. 68, 69).

Gyraulus circumstriatus, Specimens S2068-S2070

Age - In North Dakota prior to the present study, this taxon was known with certainty only from the present (Cvancara, 1976).

Modern ecology - In North Dakota, Cvancara (1983) reported that specimens were relatively uncommon but occurred mostly in permanent or intermittent pond or lake settings, with rare occurrences in intermittent streams. "G. circumstriatus is characteristic of 'small seasonal water bodies, such as woods pools, marshes, ponds on floodplains, or prairie ponds' (Taylor, 1960 , p. 57), but has been also reported from swamps and small streams, and on vegetation (Clarke, 1973, p. 398-399). In North Dakota, it was collected from permanent and intermittent ponds and lakes and intermittent streams. . . Channel widths $(n=2)$ were 2 and $3 \mathrm{~m}$. This species tolerated extremely high values of $\mathrm{pH}$....G. circumstriatus was most frequently associated with Aplexa hypnorum, and is part of the A. hypnorum-G. circumstriatus Association" (Cvancara, 1983, p. 72, 73).

Physa jennessi (EB), Specimen S2071

Age - The age range of this taxon was reported as early Pleistocene to Holocene (Hibbard and Taylor, 1960), with a North Dakota record prior to the present study known with certainty only from the present (Cvancara, 1976).

Modern ecology - In North Dakota, Cvancara (1983) reported that specimens were relatively common in permanent or intermittent pond or lake settings, with rare occurrences in intermittent streams. " $P$. jennessi has been reported from small to large lakes, permanent and temporary ponds, marshes, muskeg, and small to medium streams (Clarke, 1973, p. 365, 367, 372). In North Dakota, it was collected mostly from permanent and intermittent ponds and lakes ... Channel widths of the few $(n=4)$ stream occurrences were $2-34 \mathrm{~m}$ (mean $=17 \pm 16 \mathrm{SD})$. It was found to tolerate extreme values of total chlorides, $\mathrm{pH}$, total hardness, and total sulfates . . P. jennessi was most frequently associated with Promenetus exacuous, and is part of the Aplexa hypnorum-Gyraulus circumstriatus Association" (Cvancara, 1983, p. 83).

\section{Recurrence}

The Douglas Creek Locality paleosol dates and thicknesses were analyzed for time of recurrence and cyclicity by Dr. Vit Kühnel of the EERC (Figure 24a-c). Assumptions included that the age and thickness of paleosols are both continuous variables and that consecutive values are independent of each other. No grouping of data was attempted because of the small number of samples $(n=15)$. Note, however, that interpolated dates, as explained above, are not independent variables, as they are related to adjacent younger and older dates.

A time series of the age of the paleosols versus alluvial interval and paleosol thickness is shown in Figure 24a. Trends correspond well for the period from 3300 to 3600 YBP, correspond moderately well for the period from 2600 to $3300 \mathrm{YBP}$, and do not correspond for ages greater 
than 3600 YBP. Under the assumption that the two variables are independent, the correlation coefficient for the series $\mathrm{R}^{2}=0.86$. However, both variables are based on stratigraphic data and will be, therefore, in some manner time-dependent. Time series analysis was therefore applied to quantify this dependence and to weight down extremes and "old" data that typically carry large measurement errors.

\section{TABLE 11}

Interpolating the Age of Paleosols in Section M8302

\begin{tabular}{|c|c|c|c|c|c|c|}
\hline $\begin{array}{c}\text { Paleosol } \\
\text { Sample }\end{array}$ & $\begin{array}{c}{ }^{14} \mathrm{C} \text { Date, } \\
\mathrm{yr}\end{array}$ & $\begin{array}{c}\text { Thickness, } \\
\text { cm }\end{array}$ & $\begin{array}{l}\text { Rate, } \\
\text { yr/cm }\end{array}$ & $\begin{array}{c}\text { Time, } \\
\text { yr }\end{array}$ & $\begin{array}{c}\text { Half-Time, } \\
\text { yr }\end{array}$ & $\begin{array}{c}{ }^{14} \mathrm{C} \text { Date }+ \\
\text { Half-Time, } \\
\text { yr }\end{array}$ \\
\hline \multicolumn{7}{|l|}{ Interval 1} \\
\hline DC-02 & 2585 & $3 \div 2$ & 16.25 & 24.375 & 24.375 & 2585.00 \\
\hline DC-03 & & 4 & & 65.000 & 32.50 & 2641.88 \\
\hline DC-04 & & 10 & & 162.500 & 81.25 & 2755.63 \\
\hline \multirow[t]{2}{*}{ DC-05 } & 2910 & $9 \div 2$ & & 73.125 & 73.125 & 2910.00 \\
\hline & 325 & 20 & & 325 & & \\
\hline \multicolumn{7}{|l|}{ Interval 2} \\
\hline DC-05 & 2910 & $9 \div 2$ & 10.00 & 45.00 & 45.00 & 2910.00 \\
\hline \multirow[t]{2}{*}{ DC-06 } & 3105 & $30 \div 2$ & & 150.00 & 150.00 & 3105.00 \\
\hline & 195 & 19.5 & & 195 & & \\
\hline \multicolumn{7}{|l|}{ Interval 3} \\
\hline DC-06 & 3105 & $30 \div 2$ & 3.69 & 55.263 & 55.263 & 3105.00 \\
\hline DC-07 & & 4 & & 14.737 & 7.368 & -3167.63 \\
\hline DC-08 & & 6 & & 22.105 & 11.053 & 3186.05 \\
\hline \multirow[t]{2}{*}{ DC-09 } & 3210 & $7 \div 2$ & & 12.895 & 12.895 & 3210.00 \\
\hline & 105 & 28.5 & & 105 & & \\
\hline \multicolumn{7}{|l|}{ Interval 4} \\
\hline DC-09 & 3210 & $7 \div 2$ & 21.29 & 74.516 & 74.516 & 3210.00 \\
\hline DC-10 & & 9 & & 191.613 & 95.806 & 3380.32 \\
\hline \multirow[t]{2}{*}{$\mathrm{DC}-11$} & 3540 & $6 \div 2$ & & 63.871 & 63.871 & 3540.00 \\
\hline & 330 & 15.5 & & 330 & & \\
\hline \multicolumn{7}{|l|}{ Interval 5} \\
\hline $\mathrm{DC}-11$ & 3540 & $6 \div 2$ & 4.00 & 12.00 & 12.00 & 3540.00 \\
\hline \multirow[t]{2}{*}{$\mathrm{DC}-12$} & 3560 & $4 \div 2$ & & 8.00 & 8.00 & 3560.00 \\
\hline & 20 & 5 & & 20 & & \\
\hline \multicolumn{7}{|l|}{ Interval 6} \\
\hline $\mathrm{DC}-12$ & 3560 & $4 \div 2$ & 45.41 & 90.811 & 90.811 & 3560.00 \\
\hline DC-13 & & 9 & & 408.649 & 204.324 & 3855.14 \\
\hline DC-14 & & 3 & & 136.216 & 68.108 & 4127.57 \\
\hline DC-15 & & 6 & & 272.432 & 136.216 & 4331.89 \\
\hline \multirow[t]{2}{*}{ DC-16 } & 5240 & $34 \div 2$ & & 771.892 & 771.89 & 5240.00 \\
\hline & 1680 & 37 & & 1680 & & \\
\hline
\end{tabular}


TABLE 12

Interpolating the Age of Paleosols in Section M8303

\begin{tabular}{|c|c|c|c|c|c|c|}
\hline $\begin{array}{l}\text { Paleosol } \\
\text { Sample } \\
\end{array}$ & $\begin{array}{c}{ }^{14} \mathrm{C} \text { Date, } \\
\mathrm{yr}\end{array}$ & $\begin{array}{c}\text { Thickness, } \\
\text { cm }\end{array}$ & $\begin{array}{l}\text { Rate, } \\
\mathrm{yr} / \mathrm{cm}\end{array}$ & $\begin{array}{c}\text { Time, } \\
\mathrm{yr}\end{array}$ & $\begin{array}{c}\text { Half-Time, } \\
\text { yr }\end{array}$ & $\begin{array}{c}{ }^{14} \mathrm{C} \text { Date }+ \\
\text { Half-Time } \\
\mathrm{yr}\end{array}$ \\
\hline \multicolumn{7}{|l|}{ Interval 1 } \\
\hline DC-02 & 2585 & $4 \div 2$ & 30.95 & 61.9048 & 61.9048 & 2585.00 \\
\hline DC-03 & & 3 & & 92.8571 & 46.4286 & 2693.33 \\
\hline DC-04 & & 4 & & 123.8095 & 61.9048 & 2801.67 \\
\hline \multirow[t]{2}{*}{ DC-05 } & 2910 & $3 \div 2$ & & 46.4286 & 46.4285 & 2910.00 \\
\hline & 325 & 10.5 & & 325 & & \\
\hline \multicolumn{7}{|l|}{ Interval 2} \\
\hline DC-05 & 2910 & $3 \div 2$ & 27.86 & 41.7857 & 41.7857 & 2910.00 \\
\hline DC-06a & & 4 & & 111.4286 & 55.7142 & 3007.50 \\
\hline \multirow[t]{2}{*}{ DC-06 } & 3105 & $3 \div 2$ & & 41.7857 & 41.7857 & 3105.00 \\
\hline & 195 & 7 & & 195 & & \\
\hline \multicolumn{7}{|l|}{ Interval 3} \\
\hline DC-06 & 3105 & $3 \div 2$ & 13.13 & 19.6875 & 19.6875 & 3105.00 \\
\hline DC-07 & & 3 & & 39.3750 & 19.6875 & 3144.38 \\
\hline DC-08 & & 2 & & 26.2500 & 13.1250 & 3177.19 \\
\hline \multirow[t]{2}{*}{ DC-09 } & 3210 & $3 \div 2$ & & 19.6875 & 19.6875 & 3210.00 \\
\hline & 105 & 8 & & 105 & & \\
\hline \multicolumn{5}{|l|}{ Interval 4} & & \\
\hline DC-09 & 3210 & $3 \div 2$ & 73.3333 & 110.0000 & 110.0000 & 3210.00 \\
\hline DC-10 & & 2 & & 146.6667 & 73.3333 & 3393.33 \\
\hline \multirow[t]{2}{*}{$\mathrm{DC}-11$} & 3540 & $3 \div 2$ & & 73.3333 & 73.3333 & 3540.00 \\
\hline & 330 & 4.5 & & 330 & & \\
\hline \multicolumn{7}{|l|}{ Interval 5} \\
\hline DC-11 & 3540 & $2 \div 2$ & 8.00 & 8.0000 & 8.00 & 3540.00 \\
\hline \multirow[t]{2}{*}{ DC-12 } & 3560 & $3 \div 2$ & & 12.0000 & 8.00 & 3560.00 \\
\hline & 20 & 2.5 & & 20 & & \\
\hline \multicolumn{7}{|l|}{ Interval 6} \\
\hline$D C-12$ & 3560 & $3 \div 2$ & 55.08 & 82.6229 & 82.6229 & 3560.00 \\
\hline DC-13 & & 2 & & 110.1639 & 55.0820 & 3697.70 \\
\hline DC-14 & & 5 & & 275.4098 & 137.7049 & 3890.49 \\
\hline $\mathrm{DC}-15$ & & 5 & & 275.4098 & 137.7049 & 4165.90 \\
\hline \multirow[t]{2}{*}{ DC-16 } & 5240 & $34 \div 2$ & & 936.3934 & 936.3934 & 5240.00 \\
\hline & 1680 & 30.5 & & 1680 & & \\
\hline
\end{tabular}


The first step in the time series analysis was the determination of a frequency curve that is defined by plotting events against their probability of occurrence or return period. A frequency curve is then matched by numerical fitting with existing probability functions to obtain estimates of return periods and even magnitudes. The frequency analysis was used on intervals between paleosol events and on the paleosol thickness. The Weibull method was used to determine the relative frequency of occurrence according to their magnitude:

$$
P\left(X_{m}\right)=m /(n+1)
$$

where $\mathrm{X}_{\mathrm{m}}$ is the magnitude (alluvial duration interval), $\mathrm{P}\left(\mathrm{X}_{\mathrm{m}}\right)$ is the probability of occurrence, $\mathrm{m}$ is the rank order number, and $\mathrm{n}$ is the number of observations. This equation is one out of many plotting positions used in determining frequency curves in statistics. It was selected here for its normalized format for any value of $\mathrm{m}\left(0<\mathrm{P}\left(\mathrm{X}_{\mathrm{m}}\right)<1\right)$, its wide use in streamflow analysis, and its acceptance by the USGS. The Weibull equation was originally developed by Weibull in 1939 (see Seyhan, 1980).

Distribution of the alluvial intervals between the paleosols is best described by the twoparameter lognormal distribution. The goodness of fit between the observed and calculated values of this distribution is illustrated in Figure $24 \mathrm{~b}$. The standard deviation of this series is 85.5 , and the correlation coefficient is $R^{2}=0.77$. A final analysis was made for the product of the two series, expressed in $\mathrm{cm} \times$ yr units. The probability distribution of this series is shown in Figure 24c. The correlation coefficient between actual and calculated values of this series was $\mathrm{R}^{2}=0.92$, which is better than the average for the individual variables of duration and thickness.

Although the correlation between the raw series is relatively weak $\left(R^{2}=0.86\right)$, correlation is significantly improved when a lognormal distribution is assumed for the alluvial durations between paleosols $\left(R^{2}=0.96\right)$, as well as for the product parameter based on the paleosol thickness and the duration of the alluvial periods $\left(R^{2}=0.92\right)$. This analysis suggests that dating of the paleosols is a better measure of cyclicity than the thickness and interval position. On the basis of a lognormal distribution, the recurrence interval for a paleosol in this series is 250 years with a probability of $90 \%$.

\section{STUDY LOCALITIES}

Localities investigated and sampled as a result of this project are reviewed in the following sections and are presented in order of approximately increasing age. Their locations are shown in Figure 25.

The diverse and highly active nature of geomorphic processes operating in the Little Missouri Badlands of southwestern North Dakota make the identification of regionally applicable climatic and geomorphic patterns difficult, or at least complicated. In a broad sense, this is because the features of the basic models outlined earlier are more pronounced in natural badlands environments (Bryan and Yair, 1982). In other words, badlands are more susceptible to climatic and vegetative changes at small spatial and temporal scales. As a result, patterns recognizable in the badlands are difficult to correlate with those recognized in less dynamic landscapes (Bryan 
and Yair, 1982; Campbell, 1989; Schumm, 1956). Nevertheless, because badlands respond so readily to climatic variations, they are potentially an important source of climate data.

In the badlands of the Little Missouri River, attention focused on two stratigraphic sections along Knutson Creek, a perennial tributary of the Little Missouri River (Localities D and M). Kuehn (1995) identified four Holocene terrace fills in the South Unit of Theodore Roosevelt National Park (Figure 26). According to the basic tenets of the climatic-geomorphic models described above, the timing of the period of aggradation associated with each of these terrace fills should represent, in a broad sense, the predominance of relatively warm and dry conditions. Because of the scale and completeness of the radiometric-based chronologic framework, however, these periods of aggradation are merely rough estimates as to the timing of the initiation and termination of recognizable periods of valley sedimentation. In no single instance should it be inferred that warm and dry conditions prevailed throughout the duration of these relatively long periods. To do so would be to greatly oversimplify the geomorphic and climatological records. This inference is, in fact, countered by the presence of buried soils in many of the terrace fills. In any case, within a broad temporal scale and for the purpose of establishing a starting point for finer climatic and geomorphic resolution, episodes of fluvial aggradation are considered to represent general periods when the supply of sediment to badlands valleys outpaced stability, soil formation, and/or valley degradation. The four terrace depositional episodes are: T4, about 7000-6000; T3, about 5500-4500; T2, about 2700-800; and T1, about 400-150 YBP (Kuehn 1995). Localities D and $M$ are both associated with the T4 terrace; however, the $\mathrm{T} 1$ and $\mathrm{T} 2$ terraces are also represented at Locality $\mathrm{D}$. The climatic/geomorphic interpretations drawn from these sections are complicated by the apparent presence of more recently deposited eolian and/or slopewash mantles at the top of the T4 sediments, which, unfortunately, is where more recently deposited paleosols occur.

\section{Knutson Creek - Locality D}

Locality $\mathrm{D}$ is one of two Little Missouri River badlands localities first studied by Kuehn (1995). Exposed Paleocene-age bedrock in the badlands includes the upper part of the Bullion Creek and lower part of the Sentinel Butte Formations (about 58 to $57 \mathrm{Ma}$ ). The main geologic section of Locality D includes alluvial deposits with ages spanning over 6000 years, with a paleosol record covering some portion of the last 1400 years in the upper $1.1 \mathrm{~m}$ (Figure 27).

\section{Terrain and Location}

Locality D occurs in an alluvial sequence along Knutson Creek northwest of Medora, in the wilderness study area near the western boundary of Theodore Roosevelt National Park, Medora Quadrangle, Billings County (Figure 28). Knutson Creek is an east-flowing tributary of the Little Missouri River. In the area of Locality D, Knutson Creek meanders in a relatively broad valley of low relief, marked predominantly by steep cutbanks $6 \mathrm{~m}$ or more in height in the Oahe Formation (Figure 29). Locality D is on the south side of Knutson Creek on a 9-m-high slumped cutbank (Figure 30), about $465 \mathrm{~m}$ north of the south section line and $935 \mathrm{~m}$ east of the west section line (park boundary), in sec. 4, T. 140 N., R. 102 W. Locality D includes three terraces labeled by Kuehn (1995), from youngest to oldest, T1, T2, and T4 (Figures 30 and 31). Terrace T4 includes the main section M8297 (see Table 1) at $46^{\circ} 50^{\prime} 2.17^{\prime \prime} \mathrm{N}, 103^{\circ} 33^{\prime} 2.38^{\prime \prime} \mathrm{W}$. Short sections were 
also measured on Terrace T2 (M8311) at $46^{\circ} 57^{\prime} 56.69^{\prime \prime} \mathrm{N}, 103^{\circ} 33^{\prime} 14.04^{\prime \prime} \mathrm{W}$ and Terrace T1 (M8312) at $46^{\circ} 57^{\prime} 6.90^{\prime \prime} \mathrm{N}, 103^{\circ} 33^{\prime} 4.84^{\prime \prime} \mathrm{W}$.

\section{Modern Soil}

The modern soils on the terraces of Locality D were described as a Cherry silty clay loam, consisting of brownish gray soils (Edwards and Ableiter, 1944). This soil typically forms benches along the Little Missouri River and its larger tributaries. Edwards and Ableiter (1944) described the 5-in.- (12.7-cm)-surface soil as a friable brownish gray silt loam or silty clay loam that breaks easily into a crumbly mass, and in most places carbonates are plentiful.

\section{Geologic Section M8297}

On the basis of a previous study (Kuehn, 1995), the geologic sections represented by the terraces of Locality D were reexamined and sampled (Figure 32) for the purposes of this project. The following discussion on the section data and interpretations of this locality is edited from a report by Kuehn (1997b, unpublished report).

Terrace T4 fill alluvium at Locality $\mathrm{D}$ is approximately $6.0 \mathrm{~m}$ thick and consists of a basal unit (not exposed) of gravel and coarse sand, an intermediate unit $1.6 \mathrm{~m}$ thick of interbedded fine-to-coarse sand, mud, and granules (Kuehn, 1995, fig. 30, Unit 1; see Table 1), and an upper unit of clay loam and silt about $2.2 \mathrm{~m}$ thick (Kuehn, 1995, fig. 30, Unit 2). Each of these units exhibited primary sedimentary structures identifiable as meandering stream deposits. For this study, about $1.5 \mathrm{~m}$ of sediment below the top of Terrace T4 was described and sampled (Figures 32 and 33). Unit 14 of Section M8297a, which was recognized at the bottom of the exposure, correlates with the silty clay portion of the upper part of Kuehn's Unit 2 (T4 alluvium) (Figure 33). Likewise, Unit 13 of Section M8297a appears to correlate with the silt mantle at the top of Kuehn's Unit 2.

A radiocarbon age on charcoal of $6115+145 /-140$ YBP was recovered at a depth of $1.4 \mathrm{~m}$, which is near the top of the silty clay portion of Kuehn's Unit 2 (Kuehn, 1995) (Figure 33). This age, along with data from other locations, tentatively suggests that the $\mathrm{T} 4$ episode of aggradation ended sometime shortly after 6100 years ago. The upper approximately $1.1 \mathrm{~m}$ of sediment at Terrace T4 contains, as identified during current investigations, as many as 12 stratigraphic units comprised of silty clay loam, silty loam, and clay. A radiocarbon age of $1430 \pm 50 \mathrm{YBP}$ on charcoal was recovered from a weak Ab soil horizon that overlies Unit 13. This age suggests that the upper $1.1 \mathrm{~m}$ of sediments at this exposure was deposited within the last approximately 1400 years. In other words, there appears to be an unconformity near the top of T4 at Locality D, with a lacuna that could span at least 4500 years.

On the basis of grain-size data (Figure 34), this unconformity is likely represented at the contact between Units 13 and 14 of Section M8297a. A significant increase in clay provides adequate evidence for a lithic discontinuity (Soil Survey Staff, 1990). In any case, the lack of visible alluvial sedimentary structure and the textural data suggest that the upper $1.1 \mathrm{~m}$ was likely deposited via slopewash (Section M8297a, Units 8-13) and eolian (Units 1-7) processes. The latter depositional environment is strongly supported by grain-size composition, which exhibits 
loesslike high silt content. The most recently acquired data, therefore, suggest that $\mathrm{T} 4$ at Locality D contains a fairly substantial eolian and/or colluvial mantle of late Holocene age. Within this mantle, or within the last about 1400 years, soil formation (A horizon) was interrupted by five or six episodes of at least local instability. The $\delta^{13} \mathrm{C}$ data suggest that the locality was dominated by $\mathrm{C}_{3}$ grasses during this entire period (Figure 35).

\section{Geologic Section M8311}

Terrace $\mathrm{T} 4$ is separated laterally from the younger Terrace $\mathrm{T} 2$ fill by a visible cut-and-fill contact and a difference in elevation of about $1 \mathrm{~m}$ (Figures 30 and 31). Although no radiocarbon ages were recovered from $\mathrm{T} 2$ during the current study, other dates from Theodore Roosevelt National Park indicate that the T2 period of aggradation occurred between about 2700 and 800 YBP (Kuehn, 1995).

The T2 fill is apparently all alluvium and approximately $5.5 \mathrm{~m}$ thick. The present study focused on the exposed upper portion of the fill (Figure 36). This package of sediment, about $0.7 \mathrm{~m}$ thick, contained no less than 10 stratigraphic units and three buried soils (Section M8311). Texture was rather homogeneous, with units comprising clay loam and silty clay (Figure 37 ). The three buried soils consist of simple Entisols containing A/C-horizon profiles. The thickness of the buried A horizons ranged from 27 to $5 \mathrm{~cm}$. Because no radiocarbon data could be recovered from T2 at this locality, all that can be inferred is that sometime between about 2700 and 800 YBP, landscape stability resulting in weak soil formation was interrupted by three periods of aggradation of T2. Stable carbon isotope values on soil organic matter ranged from -23.9 to -24.8 , suggesting that $C_{3}$ vegetation dominated the local biomass during this period (Figure 38).

\section{Geologic Section M8312}

Finally, Terrace T1 is the thinnest and most recent package of alluvium at Locality D. It is distinguishable from the older T2 fill by a visible cut and fill (Figures 31 and 32). The terrace sediments are approximately $2.5 \mathrm{~m}$ thick, with the investigations focusing on the exposed upper $0.8 \mathrm{~m}$ (Figure 39). This exposure contained four stratigraphic units and two very thin and poorly developed buried soils. These consisted of weak A horizons less than $5 \mathrm{~cm}$ thick. Grain size was again quite uniform and fine (i.e., muddy silt) (Figure 40). Charcoal recovered from both paleosols yielded radiocarbon ages of $210 \pm 110$ YBP (Section M8312, Unit 2) and $145 \pm 25$ YBP (Unit 4) (Figure 41). The former "older" date is problematic in that it was derived from charcoal above Unit 4. The large analytical error on the 210 -year date indicates a younger age is possible. The greater standard deviations on dates are associated with particularly small charcoal samples. However, because the ages overlap within the one standard deviation, the difficulty is evident in attempting to radiocarbon date quite recent sediments (see Taylor, 1987). Within the last couple of hundred years, radiocarbon ages fluctuate significantly above and below the established dendrochronology curve. Nevertheless, the ages are within, or at least close to, the estimated age of the aggradation of the $\mathrm{T} 1 \mathrm{fill}$ in this region, which is about 400-150 YBP (Kuehn, 1995). The data indicate that the formation of weak soils on the T1 terrace was interrupted by periods of instability within the last several hundred years. The stable carbon isotope values from soil organic matter average -24.6 , which decidedly reflects $C_{3}$ vegetation (Figure 42). 


\section{Knutson Creek - Locality M}

Locality $\mathrm{M}$ is upstream about $0.8 \mathrm{~km}$ west of Locality $\mathrm{D}$ on a $\mathrm{T} 4$ terrace. Charcoal samples retrieved from Locality $\mathrm{M}$ were too small for radiocarbon analysis. However, the relative occurrence of paleosols on the same terrace and similar $\delta^{13} \mathrm{C}$ profiles suggest the timing of deposition for Locality $\mathrm{M}$ is comparable to that for Locality $\mathrm{D}$.

\section{Terrain and Location}

Locality $\mathrm{M}$ occurs in an alluvial sequence along Knutson Creek northwest of Medora in the wilderness study area near the western boundary of Theodore Roosevelt National Park, Medora Quadrangle, Billings County (Figures 28 and 29). In the area of Locality M, Knutson Creek meanders produce precipitous cutbanks into the Oahe Formation. Locality $\mathrm{M}$ is on the north side of Knutson Creek on west-facing exposures at the top of a high cutbank (Figure 43), about $450 \mathrm{~m}$ north of the south section line and $180 \mathrm{~m}$ east of the west section line (park boundary), in sec. 4 , T. 140 N., R. 102 W. Section M8298 was measured on Terrace T4 at Locality M at $46^{\circ} 57^{\circ}$ $56.57^{\prime \prime} \mathrm{N}, 103^{\circ} 33^{\prime} 51.37^{\prime \prime} \mathrm{W}$ (Figure 44).

\section{Modern Soil}

The modern soil on the terrace of Locality $M$ was mapped by Edwards and Ableiter (1944) as rough, broken land. The soil here, however, is more likely the same as that described for Locality D. Locality $\mathrm{M}$ is on a steep south-facing cliff, adjacent to the bottomland of the Knutson Creek drainage.

\section{Geologic Section M8298}

The section comprises T4 terrace fill, with a possible colluvial and/or eolian mantle. The terrace tread rises about $9.5 \mathrm{~m}$ above the average water level in Knutson Creek. Kuehn (1995, fig. 32; see Table 1) identified eight stratigraphic units; the lower two consist of about $8.2 \mathrm{~m}$ of trough cross-bedded sand, interbedded sand and mud, and ripple cross-laminated fine sand and silt, with some interbedded thin beds of slopewash (sand and gravels). Kuehn's Units 3 through 8 included about the upper $1.3 \mathrm{~m}$ of terrace fill and consisted of a series of thin beds, each topped with a weakly developed buried soil. The present study focused on the upper $1.3 \mathrm{~m}$ of the section. In Section M8298, 25 stratigraphic units and 10 buried soils were identified (Figures 44 and 45). Section M8298a, Units 23, 24, and 25, correlate with the upper portion of Kuehn's (1995) Unit 4 (Unit 10 of Secti,on M8298b, Figure 45), which is capped with a buried soil correlated to Unit 23, the lowest paleosol identified in Section M8298a. This, like all of the buried soils, consists of a simple A/C-horizon Entisol (silty clay). The overlying units are all thin beds of massive silt loam and silty clay loam (Figure 46). Because of massive structure, the relatively high silt content, and the lack of a typical fining-upward sequence usually associated with meandering stream deposits (Allen, 1970), it is possible, but by no means certain, that these upper units represent sediment deposition via slopewash and/or eolian processes. Because no radiocarbon data were recovered from this section, a firm temporal context for the upper $1.3 \mathrm{~m}$ of Section M8298 cannot be directly established. Although Kuehn (1995) estimated the age of the T4 terrace fill at about $6000-7000$ YBP, the possibility does exist that the upper, most recently studied, portion could be significantly younger and comparable to a confirmed age value for 
Section M8297 at Locality D. At this point, there is no way to either confirm or reject this possibility. In any case, units of Section M8298 cannot be correlated with the units of Section M8297 at Locality D, which was similarly interpreted as a eolian/colluvial mantle deposited within the last approximately 1400 years. Given this lack of correlation and temporal control, little data of relevance to the interpretation of Holocene climatic change are available from Locality $\mathrm{M}$ at the present time. Stable carbon isotope values from the buried soils range from -23.04 to -18.70 (Figure 47 ). The latter value, however, was derived from the uppermost unit of the section and may have been influenced by modern vegetation, including the possibility of nonindigenous plant species. A stable landform configuration at Locality $\mathrm{M}$ was conducive to producing numerous weak soils frequently punctuated by brief periods of aggradation in the upper $1.3 \mathrm{~m}$. The sheer number and weak stage of development evident in the soils associated with these stable episodes possibly point to local geomorphic conditions rather than significant intra- or interregional climatic changes events. However, the potential comparability of stable carbon isotope curves of Localities $\mathrm{D}$ and $\mathrm{M}$ indicate that autocyclic control of soil-forming conditions may not be the only factor in soil formation (see Interpretations, p. 4).

\section{Knife River Indian Villages - Elbee Bluff Locality}

The Elbee Bluff Locality represents one of a number of sections described by Reiten (1983) as part of his Master's studies and was chosen for reexamination in this study because of existing AMS dates. The section on Terrace $\mathrm{A}$ is mid-to-late Holocene in age, with aggradation beginning around 5000 YBP and terminating with an episode of downcutting and active floodplain abandonment around 2000-1100 YBP (Reiten, 1983, 1996, unpublished report) (Figure 48). The site was originally investigated by Reiten in 1978 and 1979 to develop the geologic history of Holocene deposition in the Knife River Indian Villages National Historic Site. At that time, three terrace cut-and-fill deposits were exposed along the Elbee Bluff. The terraces were originally named the A terrace, highest and oldest; the B1 terrace, intermediate age and elevation; and the B2 terrace, lowest and youngest (Reiten, 1983). Only the oldest terrace was evaluated and sampled for the present study.

\section{Terrain and Location}

The Elbee Bluff Locality is at the edge of the unglaciated Missouri Plateau physiographic province and represents alluvial and eolian sequences in a floodplain setting on the west bank of the Knife River on the Stanton Quadrangle, Mercer County (Figure 49). The locality is north of the Knife River's confluence with the Missouri River and occurs in the Knife River Indian Villages National Historic Site (Figure 50). The Knife River in this area forms steep cutbanks along meander bends. The Elbee Bluff Locality occurs on a 6- to 7-m-high, actively slumping cutbank (Figure 51), $2.4 \mathrm{~km}$ north of Stanton in the SW1/4 NW1/4 SE $1 / 4 \mathrm{sec} .28, \mathrm{~T} .145 \mathrm{~N}$., R. $84 \mathrm{~W}$. The bluff is located about $0.4 \mathrm{~km}$ north of a river fishing access and trail that leads to the Sakakawea Villages (Awatixa) (Figures 50 and 52). The Elbee Bluff Locality includes Section M8299, which is near protected archaeological sites, at $47^{\circ} 20^{\prime} 43.36^{\prime \prime} \mathrm{N}, 101^{\circ} 23^{\prime}$ $11.87 " \mathrm{~W}$. 


\section{Modern Soil}

The modern soil at the Elbee Bluff Locality is of the Straw series found on bottomland and higher terraces (Wilhelm and others, 1978, Sheet 42). The soils of this series are formed of material weathered from loamy alluvium and were described as a grayish brown loam to very dark grayish brown silt loam.

\section{Outcrop Conditions}

Erosion of the Elbee Bluff has significantly changed the outcrop since the fieldwork of Reiten (1983). The amount of bank erosion since 1978 is unknown, but it probably ranges from 1 to $10 \mathrm{~m}$. Large blocks of sediment have slumped or toppled away from the cutbank. These blocks are 1 to $2 \mathrm{~m}$ thick, 3 to $5 \mathrm{~m}$ high, and 10 to $15 \mathrm{~m}$ long. Many areas that used to display fresh exposures are now covered with vegetation. Consequently, many areas where cut-and-fill relationships between terraces were documented are now completely obscured (Figure 53). Although erosion in the past 18 years has exposed fresh sediment, the overall appearance of Terrace A fill is similar to what had previously been documented. Several dark horizons are clearly visible. Disseminated charcoal layers are still present in distinct dark-colored horizons, as previously observed.

\section{Geologic Section M8299}

Field studies in June 1996 concentrated on the upper approximately $3.5 \mathrm{~m}$ of the A terrace fill, which is well exposed in a vertical cutbank. The investigations in this part of the terrace revealed 21 stratigraphic units and seven buried soils. The samples are described here from top to bottom of the outcrop in order of sample number (Figure 54).

Two samples (labeled A1) for pollen and texture were collected from the modern soil horizon in the interval between 14 and $24 \mathrm{~cm}$ below the top of the bluff (at the level of Terrace A). Two samples (labeled A2) for pollen and texture were collected from the first buried soil in the interval between 55 and $73 \mathrm{~cm}$. Both of these samples were collected from a fresh slump block that provided easier access. Three samples (labeled A3) for texture, pollen, and stable carbon were collected from the second buried A horizon in the interval between 103 and $113 \mathrm{~cm}$. This horizon probably correlates with the horizon that produced preceramic artifacts (about 2000 YBP) during archaeologic excavations in 1978-1979. Three samples (labeled A4) for texture, pollen, and stable carbon were collected from the third buried A horizon in the interval between 148 and $152 \mathrm{~cm}$. Three samples (labeled A5) for texture, pollen, and stable carbon were collected from the fourth buried soil A horizon in the interval between 158 and $162 \mathrm{~cm}$. This soil appeared to be a combination of the A horizon and the B horizon of the overlying soil. Three samples (labeled A6) for texture, pollen, and stable carbon were collected from an organic layer that may be the fifth buried soil horizon or just a complex of up to four thin, organic-rich layers displaying little evidence of structure or bedding in the interval between 213 and $223 \mathrm{~cm}$. Three samples (labeled A7) for texture, pollen, and stable carbon were collected from a mottled, reduced, dark-colored layer that had originally been interpreted by Reiten (1983) as a buried soil horizon in the interval between 276 and $298 \mathrm{~cm}$. The consensus of the research team was that this layer was probably not a soil, but a clay-rich zone that had been waterlogged by groundwater after deposition. Two charcoal samples (labeled A7a and A7b) were also collected from near the 
base of this unit $(298 \mathrm{~cm})$. This charcoal appears to be from the same layer dated by Reiten (1983, SMU 708) at 2974 YBP. Alternatively, it could be from the layer dated at 3942 YBP (SMU 786) and 3870 (SMU 787) (Reiten, 1983). One sample (labeled A8) for texture was collected from a layer of well-sorted, coarse silt in the interval between 320 and $327 \mathrm{~cm}$. This sediment was finely bedded, with contorted bedding that may have been caused by postdepositional dewatering and differential compaction. Three samples (labeled A9) for texture, pollen, and stable carbon were collected from a mottled, reduced, dark-colored layer that had originally been interpreted by Reiten (1983) as a buried soil horizon in the interval between 330 and $340 \mathrm{~cm}$. This is the second mottled zone and, as previously discussed, is probably not a buried soil as previously reported. This sample is probably from the same horizon that was radiocarbon-dated at 3942 YBP (SMU 786) and 3870 YBP (SMU 787) (Reiten, 1983).

The Elbee Bluff Locality was resampled in October 1996 (Figure 55). Observations and samples were referred to Section M8299a. Samples were collected from each stratigraphic unit (Figure 56). Field observations showed that Units 2-5, 9, 14, 16, and 18 effervesce strongly, while the remaining units effervesce very strongly. Dry A-horizon colors range from dark gray to olive brown to grayish brown $(2.5 \mathrm{Y} 4 / 2,2.5 \mathrm{Y} 4 / 3,2.5 \mathrm{Y} 5 / 2)$. Texture analyses on the June and October samples were similar, except for Units 3 and 4 (Section M8299a) (Figure 57).

The lowest paleosol in Section M8299a (Unit 21 = Unit 17 of M8299), at $3.4 \mathrm{~m}$, was correlated with the S7 soil of Reiten (1983; Section M8299b, Figure 56), an Ab horizon of silty clay loam that yielded radiocarbon ages on charcoal of $3942 \pm 300$ and $3870 \pm 162$ YBP (Reiten, 1983). The rest of the section units are generally thin beds of silty clay, silt loam, clay, and silty clay loam (Figure 57). Virtually all of these units are capped with A/C-horizon Entisols. During our investigations, two charcoal samples were collected: one from Unit 18 (about $3 \mathrm{~m}$ ) of $3340 \pm$ 95 YBP and one from Unit 16 (about $2.4 \mathrm{~m}$ ) of $2974 \pm 66$ YBP. In addition, previous investigations indicated that the uppermost portion of the section, Units 1 through 6 , was deposited within the last about 2000 years (Reiten, 1983).

Since Reiten (1983, 1996, unpublished) presented evidence that channel incision and floodplain abandonment at the locality occurred between about 2000 and 1100 YBP, the alluvial origin of some of these upper units has been questioned. Indeed, the grain-size data indicate a slight decrease in clay, but a rather significant increase in sand in all of the beds above Units 5 and 6. Cumulatively, these data could indicate the input of eolian sediment (i.e., a loess mantle). In any case, the sediment, soils, and radiometric data from Elbee Bluff indicate that aggradation of the upper approximately $4 \mathrm{~m}$ at this locality was interrupted by seven or eight episodes of stability and soil formation within the last about 4000 years. Following the basic soils/landform model summarized earlier, these episodes could represent periods of relatively cool and moist climatic conditions. The stable carbon isotope data do not contradict this possibility, as five of the buried A horizons produced values ranging from -23.98 (Unit 18) to -22.48 (Unit 13), which are all good indicators of $\mathrm{C}_{3}$ floral communities (Figure 58). The Unit 9 soil, at a depth of $1.1 \mathrm{~m}$, yielded a $\delta^{13} \mathrm{C}$ value of -21.16 , which suggests the input of more $\mathrm{C}_{4}$ plants to the overall biomass during this particular episode of soil formation. 


\section{Reiten's Terrace Framework}

The Elbee Bluff section contains several dark horizons that were interpreted to be paleosols representing periods of stability that allowed the formation of A horizons. The paleosols are overlain by pale brown, silty clay formed by vertical accretion flood deposits. The paleosoloverbank deposits represent cycles of deposition and stability that provide information for interpreting climatic fluctuations during the mid-to-late Holocene time. In addition, cut-and-fill terrace deposits visible at the site may represent larger-scale cycles of erosion and deposition (Figure 53), which also may indicate climatic fluctuations between cool-moist periods and warm-dry periods. Contact relationships between adjacent Holocene terraces are useful in determining the relative age of alluvial fills or terraces. The inset terraces at the Elbee Bluff Locality indicate incision of a higher terrace followed by partial filling of alluvium. The individual terrace fills form discrete packages of sediments that can be traced throughout the lower reaches of the Knife River, both in outcrops and in map view.

Terrace A, represented by Map Unit 3 (Figure 53) is at elevations between 6 and $7 \mathrm{~m}$ above the present river level. The A terrace is restricted to the Knife River valley, but sediment similar to the upper A terrace fill is found capping the upper surface of higher Pleistocene terraces along the Missouri River. The A terrace fill can be divided into two major stratigraphic units. The lower A terrace fill unit is light brown-to-gray, fine-to-medium-grained silty sand and sandy silt containing a few thin clay beds. Sedimentary structures within this unit are high- and low-angle small-scale cross-beds, climbing ripples, and horizontal beds. This fill coarsens with depth. The base of this unit is covered, and its maximum thickness is not known. The lower A terrace fill is interpreted to be largely lateral accretion deposits formed in channel margins (Schumm, 1977).

The upper A terrace fill consists of pale brown, clayey silt containing several layers of grayish brown silt. This unit is unbedded-to-diffusely bedded and contains discontinuous layers of charcoal, pulmonate gastropods, and abundant carbonate nodules. The upper A terrace sediment is interpreted to be vertical accretion deposits that accumulated from floodwaters. The silt capping the A terrace is interpreted to be loess or reworked loess. The dark-colored bands are mainly the result of more organics and are interpreted to be paleosols.

Terrace B (Map Units 4 and 5; Figure 53) is a composite of two fill terraces forming flat surfaces between 0 and $6 \mathrm{~m}$ above river level. The B1 terrace (Map Unit 4) surface ranges from 4 to $6 \mathrm{~m}$ above river level, while the B2 terrace (Map Unit 5) surface ranges from 1 to $4 \mathrm{~m}$ and slopes into the modern floodplain. The B terrace surface is present along both the Knife and Missouri Rivers.

Terrace B1 fill unconformably overlies either the lower A terrace fill or the upper A terrace fill in the KRIV (Figure 53). The lower 1 to $2 \mathrm{~m}$ of the B1 sediment consists of dark gray, silty clay containing abundant carbonate nodules. This material is interpreted to be overbank sediment, with the dark-colored layers representing soil development. The upper B1 sediment is massive, very pale brown silt and sand containing thin beds of light gray clay. Discontinuous layers of charcoal are present in some outcrops of the upper B1 terrace fill. The upper B1 sediment is probably a combination of lateral and vertical accretion deposits. 
Terrace B2 fill can be divided into two units similar to the A terrace fill. This unit unconformably overlies either Terraces A or Bl alluvium. The lower unit is very pale brown silt and sand containing thin beds of light gray clay. Climbing ripples and convoluted plane bedding are common sedimentary structures in the lower B2 fill. Lower B2 sediment is probably a lateral accretion deposit. Upper B2 sediment consists of interlayered dark grayish brown and pale brown silty clay. This lithosome is composed of largely vertical accretion deposits.

\section{Reiten's Terrace Chronology}

The chronology of Holocene terraces is based on several different lines of evidence. The highest terrace surface is interpreted to be the oldest, and the lower terrace surfaces decrease in age with decreasing elevation. Cutbanks along the Knife River expose contacts between Terraces $\mathrm{A}, \mathrm{B} 1$, and B2 that have aided in developing a chronology of the Holocene terraces (Figure 53). Cut-and-fill relationships between the three Holocene terraces at Elbee Bluff were used to determine the relative ages of these terraces. Correlations were made by walking out terrace scarps and comparing alluvial stratigraphy.

Radiocarbon analysis has allowed development of a time framework to document the times of terrace cutting and aggradation more precisely. Radiocarbon dates from disseminated charcoal at the Elbee Bluff Locality indicate that the middle part of Terrace A fill was deposited about 3900 YBP, and charcoal from a layer about $1 \mathrm{~m}$ above this zone indicates deposition about 1000 years later (Figure 53). Artifacts from a paleosol near the base of the loess cap at the Elbee Bluff appear to be preceramic in age. These indicate that overbank deposition on the A terrace ended before about 2000 YBP. Terrace $A$ was incised between about 2000 and 1100 YBP, based on the estimated age of preceramic artifacts at.Elbee Bluff and a radiocarbon date from Terrace B1 fill at a nearby exposure (SMU 709 - 1132 YBP) (Reiten, 1983). Terrace B1 aggraded following this period of downcutting. Terrace B1 was incised sometime after this period of aggradation. Evidence suggests this incision may have been associated with a period of relatively cool and moist climate about 800 to 300 YBP.

The climatic history of early Holocene is not clearly evident in alluvial deposits along the Knife River. Any alluvial deposits older than mid-Holocene have yet to be documented. Paleoclimatic evidence does indicate a cool, moist climate following the retreat of the continental glaciers (12,000-8500 YBP). A warm, dry climate has been interpreted from about 8500 to 4500 YBP. During this dry period, the lower A terrace fill may have aggraded. Because of decreased precipitation, lower water table, and increased sediment supply, the Knife River was probably an ephemeral stream and may have been a braided stream during the mid-Holocene. By the end of the mid-Holocene unstable period, the Knife River had aggraded to a position above the present river level.

About 4500 YBP, the climate became cooler and more moist, ending the mid-Holocene unstable episode. The increased precipitation raised the water table and increased vegetation, allowing for soil development and hillslope stabilization. Flow in the Knife River increased, and the river changed to a meandering perennial stream similar to what exists today. Reworking of the mid-Holocene floodplain began at about this time. Fine-grained overbank deposits of the upper A terrace fill accumulated on the old floodplain. Soils developed on the overbank deposits, 
forming the dark-colored zones and carbonate accumulations. Floodplain forests developed, and occasional prairie fires left layers of charcoal in the overbank deposits.

Minor climatic fluctuations similar to the warm, dry "Dirty Thirties" interrupted the generally cool, moist climate of the late Holocene. One of these dry periods probably caused aggrading of the B1 floodplain to near its present level. The radiocarbon date from near the middle of the upper B1 terrace fill suggests this dry period occurred at about 1100 YBP (Reiten, 1983, SMU 709). Dating control is not adequate to date this warm, dry episode precisely, but approximate time limits for this period are suggested based on analysis of the Elbee Bluff, which includes a date of 2974 YBP (Reiten, 1983, SMU 708) in the upper A terrace fill, cut-and-fill relationships of terraces, and possible preceramic artifacts (greater than $2000 \mathrm{YBP}$ ). The terrace cutting was followed by a period of floodplain aggradation lasting until after $1100 \mathrm{YBP}$.

During the last 1100 years, much of the Terrace B1 surface has been reworked. The B2 terrace surface developed after $1100 \mathrm{YBP}$ and is forming today as the river continues to meander, reworking older alluvial fill and depositing new alluvium.

\section{Douglas Creek Locality}

The Douglas Creek Locality represents the best site presently under investigation. John Reid discovered the Douglas Creek Locality (M8314) in 1986. From his shoreline studies with the U.S. Army Corps of Engineers, the well-developed sequence of 15 buried soil horizons found at this site is now known to be extremely rare. Unfortunately, the well-exposed Douglas Creek section has undergone severe erosion as a result of high reservoir levels over the last decade and was virtually destroyed during the summer of 1996. Bison bone fragments and teeth are more plentiful at this locality than at any of the other sites, and provided additional radiocarbon source material. Encouragingly, Jon Reiten (written communication, 1997) recently reported what he believes to be a comparable section west of Douglas Creek at Lund's Landing area in Williams County.

\section{Terrain and Location}

The Douglas Creek Locality is an impressive alluvial section in a former tributary of the Missouri River near the former confluence of Douglas Creek (now flooded in the lower reaches) (Figure 59). The locality is along the north shore of Lake Sakakawea in the Douglas Creek State Game Management Area, northwest of Riverdale, Emmet SE Quadrangle, McLean County. The Douglas Creek Locality includes observation sites and Sections M8301, M8302 (main), M8303, M8304, M8310, and M8313-M8315, which are near the center of the SE1/4 sec. 11, T. 147 N., R. $86 \mathrm{~W}$ (Figures 60 and 61 ). The center of the tributary valley at the lake bluff is at $47^{\circ} 33^{\prime} 49.11^{\prime \prime}$ N, $101^{\circ} 35^{\prime} 43.37^{\prime \prime} \mathrm{W}$ (Figure 62).

\section{Modern Soil}

The modern soils in the Douglas Creek Locality area are a complex of soil types dominated by the Zahl-Max loams (Brockmann and others, 1979, sheet 110). The Arnegard series may be the soil occurring in the broken ground overlying the Oahe Formation at the locality. Brockmann 
and others (1979) reported that the Arnegard soils are typical of soils formed in alluvium in swales. The surface and subsoil layers are 25-in. $(63.5-\mathrm{cm})$-thick, organic-rich, dark grayish brown loams, underlain by mottled light brownish gray and grayish brown loam.

\section{Geologic Sections}

The Douglas Creek Locality includes a number of sections and other geologic observations (Figure 62) near the headwall of local Oahe Formation deposits. The outcrop of upper Holocene sediment begins adjacent to a slumped block of the Paleocene-age Sentinel Butte Formation, which includes a thin lignite bed (Figure 63). The Sentinel Butte sediments and adjacent till represent a source of sediment for some of the Oahe Formation, as lignite clasts are common in the Oahe.

Of the four main sections measured at the Douglas Creek Locality (Figure 64), Section M8302 is the thickest and includes the thickest paleosols. This 4-m-thick section was measured on a slumped (but still stratigraphically intact) block comprising 31 stratigraphic units and no less than 15 buried soils. Most of the soils consist of thin $(<10-\mathrm{cm})$, dark, organic-rich $A$ horizons overlying $\mathrm{C}$-horizon alluvial parent material. Two paleosols, including the lowest exposed A horizon (Unit 31) and an A horizon in the central portion of the section (Unit 11), are both over $25 \mathrm{~cm}$ thick. Based solely on thickness, these particular soils could be interpreted as cumulic, having formed under conditions when pedogenesis kept pace with the rate of aggradation (Birkeland, 1984). The Douglas Creek Locality seen in cross section (Figure 64), however, is basin-shaped, with Section M8302 near the lowest portion of the depression. Both of these thick soils appear to thin laterally, following the slope of the basin margins. Given this setting, the A-horizon thickness, rather than being cumulic in nature, could represent the rapid deposition of organic matter that accumulated at the bottom of a slowly aggrading depression. Perhaps not coincidentally, the Unit 31 soil is also the finest-grained of any soil in the section (a clay loam) and the Unit 11 soil is also quite fine-grained (a silty clay loam). Of potential additional significance is the fact that these soils contain high negative $\delta^{13} \mathrm{C}$ values, which indicate the predominance of $\mathrm{C}_{3}$ plants, plants that thrive under cool and moist conditions. The Unit 11 value is -23.46 , among the highest in the section, whereas the Unit 31 value is -22.8 .

Charcoal and bone samples recovered from the Douglas Creek Locality yielded a total of seven radiocarbon ages from distinct horizons, which cumulatively establish an excellent temporal framework for the aggradation of sediments and the timing of pedogenic episodes (see Table 4 for a list of all ${ }^{14} \mathrm{C}$ dates; Figures 65 and 66). The ages range from $5240 \pm 310$ YBP from Unit 31 at about $4 \mathrm{~m}$ to $2585 \pm 60$ YBP from Unit 3, the uppermost buried soil, at about $1.3 \mathrm{~m}$. These data indicate conclusively that most of the aggradation at Douglas Creek occurred during the middle-to-late Holocene. Several of the ages, especially those recovered from bone bioapatite, have significant standard deviations (up to \pm 695 years), which are typical of the kinds of problems associated with dating bone samples using non-AMS techniques. Nevertheless, these ages do not appear to detract significantly from and/or contradict the temporal sequence. Charcoal and bone samples obtained during this project were dated using AMS procedures (see Radiocarbon Dating, p. 26). Bison bone fragments were relatively common (Figure 67), but only one horizon had datable bone. 
In general, mean grain-size data from Section M8302 are slightly suggestive of a coarsening-upward sequence, as the lower soils tend to be dominated by clay loams and silty clay loams, whereas the upper soils are almost exclusively silty loams (Figures 68 and 69). These differences, however, are minor and not particularly uniform; therefore, climatic and geomorphic inferences on the basis of grain size are difficult to formulate at this time. Pebble lenses, composed of till clasts from nearby exposures of Coleharbor Group, are common, indicating higher-flow regimes at times during the deposition of the Oahe Formation (Figure 70).

In addition to the information previously mentioned from Units 11 and 31 , the $\delta^{13} \mathrm{C}$ stable carbon values on soil organic matter indicate a predominance of $\mathrm{C}_{3}$ biomass throughout most of the Douglas Creek sequence (Figures 71 and 72 ). These range from -19.59 to -23.69 . The least negative values were from buried soils highest up in the section and indicate input of some $\mathrm{C} 4$ biomass (Thomas Boutton, personal communication, 1997). Chronostratigraphically, these soils formed between about 2900 and 2000 YBP and could indeed reflect a period (or periods) of somewhat warmer and drier conditions.

Besides Section M8302, textural analysis was conducted on Section M8301 (Figures 73-75), Section M8303 (Figures 76-78), and Section M8304 (Figures 79-81). Beck and Hartman (1997, p. 161) summarize the $\mathrm{Ab}$ and $\mathrm{C}$ horizons as follows: "The average thickness of the $\mathrm{Ab}$ horizons is $5 \mathrm{~cm}$, with a range of 2 to $34 \mathrm{~cm}$. The $\mathrm{Cb}$ horizons are generally thicker than the $\mathrm{Ab}$ horizons, averaging $10 \mathrm{~cm}$, ranging from 3 to $32 \mathrm{~cm}$. Each $\mathrm{Ab}$ horizon is characterized by humus, lignite fragments, and its brown color (10YR 5/3). Cb horizons are free of organic material, olive in color (5Y 5/3), and in many cases, have ribbons of carbonate. The grain size of the $\mathrm{Ab}$ horizons consists of clay ranging from $4 \%$ to $37 \%(\bar{x}=23.5 \%)$; silt, ranging from $44 \%$ to $71 \%(\bar{x}=59.6 \%)$; and sand, ranging from $6 \%$ to $30 \%(\bar{x}=17 \%)$. The ranges and means of grain size in $\mathrm{Cb}$ horizons are as follows: clay from $17 \%$ to $33 \%(\bar{x}=27 \%)$; silt from $47 \%$ to $60 \%(\bar{x}=$ $54 \%)$; and sand from $8 \%$ to $26 \%(\bar{x}=19 \%)$. Comparison of $\mathrm{Ab}$ and $\mathrm{C}$ horizons reveals that silt is more abundant in A horizons and clay is more abundant in $\mathrm{C}$ horizons."

In total, the data from the Douglas Creek section in general and subsection DC or M8302 in particular suggest that one episode of stability and soil formation occurred shortly prior to about 5000 YBP, three episodes occurred between about 5000 and 3800 YBP, seven episodes occurred between about 3800 and 3000 YBP, and four episodes occurred after about 2000 YBP. The radiocarbon data further suggest that soil formation is particularly well documented at around 3500 YBP and between about 3200 and 3000 YBP. That these soil-forming episodes occurred under relatively cool and moist conditions is further substantiated by the stable carbon isotope data.

\section{Riverdale Locality}

The only stratigraphic locality investigated as a result of this study that was not associated with an alluvial depositional environment was the Riverdale section, the type site for the Oahe Formation and its members (Figure 82). The Riverdale Member was originally defined by Clayton and others (1976) to encompass late Quaternary upland silt throughout North Dakota. It was later redefined to include all sediment overlying the late Wisconsin (Pleistocene) Coleharbor Group, regardless of depositional environment (Clayton and Moran, 1979). 


\section{Terrain and Location}

An eolian (loess) sequence forms the stratotype of the Oahe Formation on west-facing high cliffs along the eastern shore of Lake Sakakawea north of the town of Riverdale, in the Wolf Creek State Game Management Area, Riverdale North Quadrangle, McLean County (Figures 83 and 84). The Riverdale Locality includes Section M8300, which is at about the center of sec. 22, T. 147 N., R. 84 W., at $47^{\circ} 32^{\prime} 18.48^{\prime \prime} \mathrm{N}, 101^{\circ} 21^{\prime} 55.22^{\prime \prime} \mathrm{W}$. The section mantles a near-vertical cutbank, which was created by the erosive wave action on Lake Sakakawea on the poorly cemented sediments of the Paleocene-age Fort Union Group. Although the cutbank is about $15 \mathrm{~m}$ high, the Oahe Formation comprises only the upper $2 \mathrm{~m}$, but includes three of the four members of the Oahe Formation (Figures 9 and 82).

\section{Modern Soil}

The modern soils of the Riverdale Locality are of the Cabba series (CbF), which is associated with "shale outcrops" in steep-to-very steep terrains (Brockmann and others, 1979, sheet 118). Soils typically consist of variably thick grayish brown loam underlain by light gray loam.

\section{Geologic Section M8300}

From oldest to youngest the Riverdale section includes the Aggie Brown (about 13,000-8500 YBP), the Pick City (about 8500-4500 YBP), and the Riverdale (about 4500 YBP to the recent) Members of the Oahe Formation (Figure 85). The ages of these units were originally suggested by Clayton and others (1976; fig. 4) in the absence of radiocarbon data and have since proven to be remarkably accurate (Artz, 1995). No numeric ages were recovered as a result of present investigations (see below). There is however, no evidence to suggest that the three Oahe Formation members present at the Riverdale section do not fall within this general time frame.

Eight stratigraphic units were recognized in Section M8300 at the Riverdale Locality. All units comprise massive silt (Figure 86). The lowest unit, Unit 8, represents the late Pleistocene-early Holocene Aggie Brown Member. A distinctive feature of the Aggie Brown is the presence of a prominent soil, originally designated the Leonard Paleosol by Bickley (1972). The Leonard soil was indeed visible at the Riverdale section, although it was somewhat irregular in thickness and lateral distribution. Unit 7 (M8300) corresponded to the middle Holocene Pick City Member. It directly overlies the Leonard Paleosol and consists of a thick bed of light brown silt with no visible A horizon. A bone sample was collected from this interval, but it had insufficient collagen to derive a radiocarbon date (UAZ, written communication, 1997). The upper Units 1-6 are comprised by the late Holocene Riverdale Member at this locality. They correspond to the lower (Units 5 and 6), middle (Unit 4), and upper (Units 1,2,3) submembers of the Riverdale Member. The top of the sequence, Unit 1, is the modern surface soil.

Because no new radiometric data were recovered from the Riverdale section, little can be said about climate-landform associations. As stated earlier, the fairly extensive existing record from the Little Missouri badlands suggests that the late Pleistocene-early Holocene Leonard Paleosol formed on conditions that were wetter and cooler than present (Kuehn, 1996), while the 
overlying Pick City Member formed under relatively warm and dry conditions during the middle Holocene. The lower Riverdale submember marks a return to more mesic conditions around 4500 YBP, whereas the upper two submembers reflect climatic conditions similar to those of historic times (Clayton and others, 1976). In some upland loess deposits in western North Dakota, as many as twelve buried soils have been identified in the Riverdale Member (Jorstad and others, 1986).

Stable carbon isotope samples were collected from each of the Oahe Formation members and submembers (Figure 87) and processed by Boutton (written communication, 1997) (Table 5). These $\delta^{13} \mathrm{C}$ values do not seriously contradict the basic climatic inferences associated with the deposition of the Oahe Formation eolian lithofacies. Indeed, the sample with the highest degree of input from $\mathrm{C}_{3}$ plants was the one collected from the Leonard Paleosol (-23.33) (Figure 87). In the overlying units, the stable carbon values steadily become more $\mathrm{C}_{4}$-like, peaking in the lower Riverdale unit at -19.59 . In the middle and upper Riverdale subunits, the values become more $\mathrm{C}_{3}$-like, with the sample collected from the modern surface soil yielding a value of -21.18 . The only enigmatic aspect of these data is the fact that the greatest negative $\delta^{13} \mathrm{C}$ value did not come from the Pick City Member, but rather the lower Riverdale, which has been traditionally interpreted as being deposited during a return to relatively cool and moist conditions. Although this would appear somewhat surprising, the trend evident at the Riverdale section is virtually identical to $\delta^{13} \mathrm{C}$ curves reported on samples collected from two upland loess sections in the Little Missouri badlands (Kuehn, 1995). These localities, designated O and A (Kuehn 1995) are both well-dated thick eolian mantles containing the Aggie Brown, Pick City, and Riverdale Members. Again, negative values are highest in the Aggie Brown Member and steadily become lower until reaching their lowest levels in the bottom (oldest) units associated with the Riverdale Member (Kuehn, 1995, fig. 49). The similarities between stable carbon values in these three loess sections do not appear to be coincidental, but rather suggestive of an emerging pattern. The causal factors behind this pattern (that is, the greatest $\mathrm{C}_{4}$-like values occurring in the lower Riverdale rather than in the Pick City) have still not been determined. Kuehn (1995) and Boutton (personal communication, 1995) suggest that the peak in $\mathrm{C}_{4}$ biomass soon after the initial deposition of the Riverdale Member could reflect overgrazing caused by the return of large numbers of bison to the area after the amelioration of poor pasture conditions that occurred during the middle Holocene (i.e., the Altithermal). A great deal of additional data from upland loess sections throughout North Dakota are needed, however, before this possibility can be properly tested.

\section{Fryburg Area - Locality C}

The Leonard Paleosol was sampled at Locality C (Figure 88 ) potentially to serve as a marker horizon for comparison to the Riverdale and other localities. The absence of datable materials at the Riverdale Locality and the significantly younger age of the other localities negated any reason to pursue analysis and study of this site beyond the earlier work of Kuehn (1995). 


\section{Terrain and Location}

The sampled horizon at Locality $\mathrm{C}$ represents an upland eolian bed north-northwest of Fryburg, north of Interstate I-94, near the eastern boundary of Theodore Roosevelt National Park, Fryburg NE Quadrangle, Billings County. A sample of the Leonard Paleosol (Section M8291) of the Oahe Formation was collected from near the grass-badlands bedrock contact on the north side of a tributary at the head of a tributary of Paddock Creek, north of the Talkington Trail, about $650 \mathrm{~m}$ south of the north section line and about $220 \mathrm{~m}$ west of the east section line, in sec. 29, T. 140 N., R. 100 W. ( $46^{\circ} 54^{\prime} 48.57^{\prime \prime}$ N, $103^{\circ} 19^{\prime} 6.05^{\prime \prime}$ W) (Figures 89 and 90).

\section{Modern Soil}

The modern soils of this area were described as a Patent clay loam (slope phase) consisting of brownish gray silt loams, clay loams, and clays (Edwards and Ableiter, 1944) adjacent to bedrock of the Sentinel Butte Formation. Edwards and Ableiter (1944) stated that the surface soil is generally 3 or 4 in. [7.6-10.1 cm] thick and is underlain by gray or yellowish gray clay loam, with carbonates generally distributed throughout the entire depth of this soil.

\section{Geologic Section M8291}

Kuehn (1995, fig. 18) reported four units from a 2.3-m section at Locality C (here referred to as M8291a). The late Quaternary part of the section rests on weathered strata of the Paleoceneage Sentinel Butte Formation ( $57 \mathrm{Ma}$ ) (Figures 88 and 90). The Leonard Paleosol of the Aggie Brown Member yielded an age of 10,740 \pm 120 YBP on a bulk organic carbon-rich sample (Kuehn, 1995) (Figure 91). The overlying Units II and III correspond to the middle Holocene Pick City and late Holocene Riverdale Members. As described by Kuehn (1995), both the Pick City and Riverdale units are composed of thick beds of silt.

\section{ACKNOWLEDGMENTS}

This project was cofunded by the Electric Power Research Institute and the U.S. Department of Energy through the Energy \& Environmental Research Center (EERC). This report is a product of the efforts of a number of individuals (see Personnel section, p. 16). Text of their reports has been wholly or in part incorporated here. Of specific note are contributions by Kuehn (1997b, unpublished report), Reiten (1996, unpublished report), and Beck (1996, 1997, unpublished reports) in their areas of expertise.

\section{REFERENCES}

Allen, J.R.L., 1970, Studies in fluviatile sedimentation-A comparison of fining-upward cyclothems, with special reference to coarse-member composition and interpretation: Journal of Sedimentary Petrology, v. 40, p. 298-323.

Artz, J.A., 1995, Geological contexts of the early and middle Holocene archaeological record in North Dakota and adjoining areas of the Northern Plains, in Bettis, E.A., III, ed., 
Archaeological geology of the Archaic Period in North America: Geological Society of America Special Paper 297, p. 67-86.

Baillie, M.G.L., 1982, Tree ring dating and archaeology: New York, Columbia University Press, $274 \mathrm{p}$.

Baker, F.C., 1920, The life of the Pleistocene or glacial period as recorded in the deposits laid down by the great ice sheets: Urbana, University of Illinois, $476 \mathrm{p}$.

Barnosky, C.W., 1989, Postglacial vegetation and climate in the northwestern Great Plains of Montana: Quaternary Research, v., 31, p. 57-73.

Barry, R.G., 1983, Climatic environment of the Great Plains, past and present, in Caldwell, W.W., Schultz, C.B., and Stout, T.M., A Symposium-Man and the Changing Environments in the Great Plains: Nebraska Academy of Sciences Transactions, v. 11, p. $45-55$.

Beck, D.L., 1996, Texture analysis methods: Grand Forks, University of North Dakota Energy \& Environmental Research Center, unpublished report [as part of Master's thesis research in progress].

Beck, D.L., 1997, Analysis of phytolith assemblages-Cluster and factor analysis, Douglas Creek Locality, McLean County, North Dakota: Grand Forks, University of North Dakota Energy \& Environmental Research Center, unpublished report.

Beck, D.L., and Hartman, J.H., 1997, Paleosols as proxy climatic change indicators in central North Dakota: North Dakota Academy of Science (1997 Annual Meeting), Proceedings, v. 51, p. 161.

Bickley, W.B., Jr., 1972, Stratigraphy and history of the Sakakawea sequence, south-central North Dakota [Ph.D. Dissertation]: Grand Forks, University of North Dakota.

Birkeland, P.W., 1984, Soils and geomorphology: New York, Oxford University Press, 372 p.

Bluemle, J.P., 1991, The face of North Dakota, revised edition: North Dakota Geological Survey Educational Series 21, $73 \mathrm{p}$.

Bluemle, J.P., and Clayton, L., 1982, Geologic time in North Dakota: North Dakota Geological Survey Educational Series 14, 18 p.

Boutton, T.W., 1991, Stable carbon isotope ratios of natural materials - II. Atmospheric, terrestrial, marine, and freshwater environments, in Coleman, D.C., and Fry, B., Carbon isotope techniques: San Diego, Academic Press, Inc., p. 173-185. 
Boutton, T.W., 1996, Stable carbon isotope ratios of soil organic matter and their use as indicators of vegetation and climate change, in Boutton, T.W., and Yamasaki, S., eds., Mass spectrometry of soils: New York, Marcel Dekker, Inc., p. 47-82.

Boutton, T.W., Nordt, L.C., Archer, S.R., Midwood, A.J., and Casar, I., 1993, Stable carbon isotope ratios of soil organic matter and their potential use as indicators of paleoclimate, in International Symposium on Isotope Techniques in the Study of Past and Current Environmental Changes in the Hydrosphere and the Atmosphere, Proceedings: Vienna, Austria, International Atomic Energy Agency, p. 445-459.

Boutton, T.W., Nordt, L.C., and Kuehn, D.D., 1997, Late Quaternary vegetation and climate change in the North American Great Plains-Evidence from $\delta_{13} \mathrm{C}$ of paleosol organic carbon: Paper presented at International Symposium on isotope techniques in the study of past and current environmental changes in the hydrosphere and the atmosphere: Vienna, Austria, International Atomic Energy Agency.

Bradbury, J.P., Dean, W.E., and Anderson, R.Y., 1993, Holocene climatic and limnologic history of the north-central United States as recorded in the varved sediments of Elk Lake, Minnesota-A synthesis: Geological Society of America, Special Paper 276, p. 309-328.

Brakenridge, G.R., 1987, River flood regime and floodplain stratigraphy, in Baker, V.R., Kochel, R.C., and Patton, P.C., Flood geomorphology: New York, John Wiley and Sons, p. 139-156.

Brockmann, L.C., Evenson, E.E., Strum, J.F., Anderson, T.C., Jr., Freymiller, W.F., Weiser, P.K., and Howey, R.L., 1979, Soil survey of McLean County, North Dakota: U.S. Department of Agriculture Soil Conservation Service (in cooperation with the Bureau of Indian Affairs and the North Dakota Agricultural Experiment Station), 218 p., 174 maps.

Bryan, R., and Yair, A., 1982, Perspectives on studies of badland geomorphology, in Bryan, R., and Yair, A., eds., Badland geomorphology and piping: Norwich, England, Geo Books, p. 1-12.

Bryant, V.M., Jr., and Hall, S.A., 1993, Archaeological palynology in the United States - A critique: American Antiquity, v. 58, p. 277-286.

Bryson, R.A., Baerreis, D.A., and Wendland, W.M., 1970, The character of late-glacial and postglacial climatic changes, in Dort, W., Jr., and Jones, J.K., Jr., eds., Pleistocene and recent environments of the central Great Plains: Lawrence, University Press of Kansas, p. 53-74.

Burch, J.B., 1989, North American freshwater snails: Hamburg, Michigan, Malacological Publications, 365 p.

Butzer, K.W., 1976, Geomorphology from the earth: New York, Harper and Row. 
Campbell, I.A., 1989, Badlands and badland gullies, in Thomas, D.S.G., Arid zone geomorphology: London, Belhaven Press, p. 159-183.

Clarke, A.H., 1973, The freshwater molluscs of the Canadian Interior Basin: Malacologia, v. 13, p. $1-509$.

Clarke, A.H., 1979, Gastropods as indicators of trophic lake stages: Nautilus, v. 93, p. 138-142.

Clayton, L.S., and Moran, S.R., 1979, Oahe Formation, in Groenewold. G.H., Hemish, L.A., Cherry, J.A., Rehm, B.W., Meyer, G.N., and Winczewski, L.M.. Geology and geohydrology of the Knife River Basin and adjacent areas of west-central North Dakota: North Dakota Geological Survey Reports of Investigation 64, p. 337-339.

Clayton, L.S., Moran, S.R., and Bickley, W.B., Jr., 1976, Stratigraphy, origin, and climatic implications of late Quaternary upland silt in North Dakota: North Dakota Geological Survey Miscellaneous Series 54, 15 p.

Clayton, L.S., and Tinker, J.R., Jr., 1971, Rates of hillslope lowering in the badlands of North Dakota: North Dakota Water Resources Research Institute Report WI-221-012-71.

Council on Environmental Quality, 1989, Environmental trends: Washington, DC, U.S. Government Printing Office, $152 \mathrm{p}$.

Cvancara, A.M., 1976, Aquatic mollusks in North Dakota during the last 12,000 years: Canadian Journal of Zoology, v. 54, no. 10, p. 1688-1693.

Cvancara, A.M., 1983, Aquatic mollusks in North Dakota: North Dakota Geological Survey Report of Investigation 78, 141 p., 6 pls.

Derbyshire, E., 1976, Geomorphology and climate: London, John Wiley and Sons.

Doher, L.I., 1980, Palynomorph preparation procedures currently used in the paleontology and stratigraphy laboratories, U.S. Geological Survey: U.S. Geological Survey Circular 830, $29 \mathrm{p}$.

Engstrom, D.R., and Nelson, S.R., 1991, Paleosalinity from trace metals in fossil ostracodes compared with observational records at Devils Lake, North Dakota, USA: Palaeogeography, Paleoclimatology, Palaeoecology, v. 83, p. 295-312.

Erhart, H., 1967, La genèse des sols en tant que phénomène géologique, 2nd ed.: Paris, Masson.

Edwards, M.J., and Ableiter, J.K., 1944, Soil survey of Billings County, North Dakota: U.S. Department of Agriculture Division of Soil Survey (in cooperation with the North Dakota Agricultural Experiment Station), ser. 1934, no. 25, 111 p., 7 pls., 1 map.

Fenneman, N.M., 1931, Physiography of western United States: New York, McGraw-Hill. 
Folland, C.K., Karl, T.R., and Vinnikov, K.Y., 1991, Observed climate variations and change, in Houghton, J.T., Jenkins, G.J., and Ephraums, J.J., eds., Climate change-The IPCC scientific assessment: Cambridge, Cambridge University Press, p. 195-238.

Fredlund, G.G., 1997, Phytolith analysis of Holocene alluvial sediments and soils from western North Dakota: Grand Forks, University of North Dakota Energy \& Environmental Research Center, unpublished report.

Fredlund, G.G., and Tieszen, L.T., 1994, Modern phytolith assemblages from the North American Great Plains: Journal of Biogeography, v. 21, p. 321-335.

Fritz, S.C., Juggins, S., Battarbee, R.W., and Engstrom, D.R., 1991, Reconstruction of past changes in salinity and climate using a diatom-based transfer function: Nature, v. 352, p. 706-709.

Fritz, S.C., Engstrom, D.R., and Haskell, B.J., 1994, Little Ice Age' aridity in the North American Great Plains-A high-resolution reconstruction of salinity fluctuations from Devils Lake, North Dakota, USA: The Holocene, v. 4, no. 1, p. 69-73.

Gonzalez, M.A., 1987, Fluvial geomorphology of Paddock Creek, Little Missouri badlands, southwestern North Dakota [Master's thesis]: Madison, University of Wisconsin.

Hamilton, T.M., 1967, Recent fluvial geology in western North Dakota [M.S. thesis]: Grand Forks, University of North Dakota.

Harman, W.N., 1972, Benthic substrates-Their effect on fresh-water Mollusca: Ecology, v. 53, p. 271-277.

Hardin, J.W., 1982, A quantitative index of soil development from field descriptions-Examples from a chronosequence in central California: Geoderma, v. 28, p. 1-28.

Hartman, J.H., 1997a, The ever present chance of flooding, in Hartman, J.H., ed., Symposium on the Red River Flood of 1997-Involving Science in Future Watershed Management

Decisions: North Dakota Academy of Science, Proceedings, v. 51, Supplement 1, p. 51, 52.

Hartman, J.H., ed., 1997b, Symposium on the Red River Flood of 1997-Involving Science in Future Watershed Management Decisions: North Dakota Academy of Science, Proceedings, v. 51, Supplement 1, 52 p.

Hartman, J.H., Beck, D.L., Kuehn, D.D., Reid, J.R., and Reiten, J., 1997, Paleosols as proxy data for climate change-Interpreting Holocene deposits in the badlands and prairies of western North Dakota: Geological Society of America, Abstracts with Programs, v. 29, no. 6, p. A-34.

Haynes, C.V., Jr., 1968, Geochronology of Late-Quaternary alluvium, in Morrison, R.B., and Wright, H.E., Jr., Means of correlation of quaternary successions: Salt Lake City, 
University of Utah Press, Proceedings of the VII Congress, International Association for Quaternary Research, v. 8, p. 591-631.

Hibbard C.W., and Taylor, D.W., 1960, Two late Pleistocene faunas from southwestern Kansas: University of Michigan Museum of Paleontology, v. 16, p. 1-223.

Hubricht, L., 1985, The distributions of the native land mollusks of the eastern United States: Fieldiana [Field Museum], Zoology new series 24, $191 \mathrm{p}$.

Jorstad, T., East, T., Adovasio, J.M., Donahue, J., and Stuckenrath, R., 1986, Paleosols and prehistoric populations in the high plains: Geoarchaeology, v. 1, p. 163-181.

Karlen, I., Olsson, I.U., Kallburg, P., and Kilici, S., 1968, Absolute determination of the activity of two ${ }^{14} \mathrm{C}$ dating standards: Arkiv Geofysik, v. 4, p. 465-471.

Kerney, M.P., and Cameron, R.A.D., 1994, Collins field guide—Land snails of Britain and north-west Europe: London, Harper Collins Publishers, 288 p.

Knox, J.C., 1983, Responses of river systems to Holocene climates, in Wright, H.E., Jr., ed., Late-Quaternary environments of the United States, v. 2, The Holocene: Minneapolis, University of Minnesota Press, p. 26-41.

Knox, J.C., 1984, Fluvial responses to small-scale climatic changes in Costa, J.E., and Fleisher, P.J., Developments and applications of geomorphology: Berlin, Springer-Verlag, p. 318-342.

Kroeger, T.J., 1995, The paleoecologic significance of Paleocene palynomorph assemblages from the Ludlow, Slope, and Cannonball Formations, southwestern North Dakota [Ph.D. dissertation]: Grand Forks, University of North Dakota.

Kroeger, T.J., 1996, Progress reports-Palynological analysis, Holocene alluvial cycles project: Grand Forks, University of North Dakota Energy \& Environmental Research Center, unpublished reports.

Kuehn, D.D., 1996, The Aggie Brown Member of the Oahe Formation-A late Pleistocene-early Holocene marker horizon in western North Dakota: Current Research in the Pleistocene, v. 13 , p. 121-123.

Kuehn, D.D., 1995, The geoarchaeology of the Little Missouri Badlands-The Late Quaternary stratigraphic and paleoenvironmental context of the archaeological record [Ph.D. Dissertation]: College Station, Texas A\&M University.

Kuehn, D.D., 1997a, Progress report-Holocene cyclicity project, western North Dakota: Grand Forks, University of North Dakota Energy \& Environmental Research Center, unpublished report. 
Kuehn, D.D., 1997b, Draft final report-Holocene cyclicity project, western North Dakota: Grand Forks, University of North Dakota Energy \& Environmental Research Center, unpublished report.

Laird, K.R., Fritz, S.C., Grimm, E.C., and Mueller, P.G., 1996, Century-scale paleoclimatic reconstruction from Moon Lake, a closed-basin lake in the northern Great Plains: Limnology and Oceanography v. 41 , no. 5, p. 890-902.

La Rocque, A., 1970, Pleistocene Mollusca of Ohio: State of Ohio Division of Geological Survey Bulletin 62, pt. 4, 555-800, pls. 15-18.

Langbein, W.B., and Schumm, S.A., 1958, Yield of sediment in relation to mean annual precipitation: Transactions of the American Geophysical Union, v. 39, p. 1076-1084.

McAndrews, J.H., 1966, Postglacial history of prairie, savanna, and forest in northwestern Minnesota: The Torrey Botanical Club Memoirs, v. 22, no. 2, 72 p., 6 pls.

McAndrews, J.H., Stewart, R.E., Jr., and Bright, R.C., 1967, Paleoecology of a prairie pothole-A preliminary report, in Clayton, L., and Freers, T.F., eds., Glacial geology of the Missouri Coteau and adjacent areas: North Dakota Geological Survey Miscellaneous Series 30, p. 101-113.

McFaul, M., 1990, Geoarchaeological potential of Souris River terrains, Renville County, North Dakota: Journal of the North Dakota Archaeological Association, v. 4, p. $17-42$.

Munsell Soil Color Charts', 1992, Munsell soil color charts: Newburgh, New York, Macbeth, Division of Kollmorgen Instruments Corporation.

Olsson, I.U., 1970, The use of oxalic acid as a standard, in Olsson, I.U., ed., Radiocarbon variations and absolute chronology (Nobel Symposium, 12th Proceedings): New York, John Wiley \& Sons.

Patton, P.C., and Schumm, S.A., 1975, Gully erosion, northwestern Colorado-A threshold phenomenon: Geology, v. 3, p. 88-90.

Peltier, L.C., 1950, The geographic cycle in periglacial regions as it related to climatic geomorphology: Annals of the Association of American Geographers, v. 40, p. 214-236.

Perkins, R.L., 1977, The late Cenozoic geology of west-central Minnesota from Moorhead to Park Rapids [Master's thesis]: Grand Forks, University of North Dakota.

Picard, M.D., and High, L.R., Jr., 1972, Criteria for recognizing lacustrine rocks, in Rigby, J.K., and Hamblin, W.K., ed., Recognition of ancient sedimentary environments: Society of Economic Paleontologists and Mineralogists Special Publication 16, p. 108-145. 
Pilsbry, H.A., 1948, Land Mollusca of North America (north of Mexico): Academy of Natural Sciences of Philadelphia Monograph 3, p. ix-XIVIII, 521-1113.

Reid, J.R., ed., 1997, The Devils Lake Basin-A Scientific Perspective (symposium): North Dakota Academy of Science, Proceedings, p. 4-60.

Reiten, J., 1983, Quaternary geology of the Knife River Indian Villages National Historic Site [M.S. thesis]: Grand Forks, University of North Dakota.

Reiten, J., 1996, Field report-Holocene alluvial cycles in westem North Dakota, Elbee Bluff Site, Knife River Indian Villages NHS: Grand Forks, University of North Dakota Energy \& Environmental Research Center, unpublished report.

Ritter, D.F., 1978, Process geomorphology: Dubuque, Iowa, Wm. C. Brown Company.

Schumm, S.A., 1956, The role of creep and rainwash on the retreat of badland slopes: American Journal of Science, v. 254, p. 693-706.

Schumm, S.A., 1973, Geomorphic thresholds and complex response of drainage systems, in Morisawa, M., ed., Fluvial geomorphology: Binghampton, State University of New York, Publications in Geomorphology, p. 299-310.

Schumm, S.A., 1977, The fluvial system: New York, John Wiley \& Sons, 338 p.

Seidel, R. E., 1986, Deflation basin stratigraphy_Southwestern North Dakota [Ph.D. dissertation]: Grand Forks, University of North'Dakota.

Seyhan, E., 1980, Application of statistical methods to hydrogeology: Amsterdam, Free University Institute of Earth Sciences, 2nd ed.

Singer, M.J., and Janitzky, P., 1986, Field and laboratory procedures used in soil chronosequence study: U.S. Geological Survey Bulletin 1648, 49 p.

Soil Survey Staff, 1990, Keys to soil taxonomy: Blacksburg, Virginia, U.S. Department of Agriculture, Soil Management Support Services Technical Monograph 19, 4th ed.

Soil Survey Staff, 1993, Soil survey manual: Washington, DC, U.S. Department of Agriculture Handbook 18, 437 p.

Stach, E., Mackowsky, M.-Th., Teichmüller, M., Taylor, G.H., Chandra, D., and Teichmüller, R., 1982, Stach's textbook of coal petrology, 3rd ed.: Berlin, Gebrüder Bontraeger.

Stuiver, M., and Reimer, P.J., 1986, A computer program for radiocarbon age calibration, in Stuiver, M., and $\mathrm{Kra}$, R.S., eds., Proceedings of the 12 th International ${ }^{14} \mathrm{C}$ Conference, Radiocarbon 28 (2B), p. 1022-1030. 
Stuiver, M., 1980, Workshop on ${ }^{14} \mathrm{C}$ data reporting: Radiocarbon, v. 22, p. 964-966.

Stuiver, M., and Polach, H.A., 1977, Discussion-Reporting of ${ }^{14} \mathrm{C}$ data: Radiocarbon, v. 19 , p. $355-363$.

Taylor, D.W., 1960, Late Cenozoic molluscan faunas from the high plains: U.S. Geological Survey Professional Paper 337, 85 p.

Taylor, R.E., 1987, Radiocarbon dating—An archaeological perspective: New York, Academic Press.

Traverse, A., 1988, Paleopalynology: Winchester, Massachusetts, Allen and Unwin Inc., 600 p.

Twiss, 1983, Dust and deposition and opal phytoliths in the Great Plains, in Caldwell, W.W., Schultz, C.B., and Stout, T.M., A Symposium-Man and the Changing Environments in the Great Plains: Nebraska Academy of Sciences Transactions, v. 11, p. 73-82.

VanderBusch, D., 1991, Soil survey of Mountrail County, North Dakota: U.S. Department of Agriculture Soil Conservation Service, 187 p., 147 maps.

Wilhelm, F.J., Aziz, F.P., Dalsted, K.J., Thompson, K.W., and Weiser, P.K., 1978, Soil survey of Mercer County, North Dakota: U.S. Department of Agriculture Soil Conservation Service (in cooperation with the Bureau of Indian Affairs and the North Dakota Agricultural Experiment Station), 223 p., 84 maps. 


\section{FIGURE EXPLANATIONS}

\section{INTRODUCTION}

Figure 1. Holocene cyclicity in western North Dakota - climatic change interpreted from fluctuations in alluvial sedimentation. This figure shows the valley of the headwaters of Knutson Creek, a typical tributary of the Little Missouri River, dominated by alluvial sedimentation and bounded by 56 -to- 58 -million-year-old nonmarine strata, also deposited predominantly by alluvial processes. This study includes analyses of paleosol sequences ranging from over 5000 to 145 YBP, spanning periods of known temperature fluctuations (Folland and others, 1991).

Figure 2. Natural climatic variation influenced by human activity. Variation in climate, reflecting changes in $\mathrm{CO}_{2}$ levels as well as many other biospheric components, has occurred continuously throughout billions of years of earth history. Of concern today is the exacerbation of normal climate change as a by-product of human industry. Understanding the history and extent of climate change and the magnitude of human impact is necessary to develop effective policy on resource management and utilization.

Figure 3. Holocene chronologies and climate. This figure summarizes chronological data for Great Plains areas during the Holocene, as of Barry (1983, table II). Climate change summaries for this interval have been changing rapidly as the number of tightly controlled radiometric dates increases the resolution of interpretation. The work by Barry (1983) provides a broadscale understanding of the Holocene climate. Altithermal (Holocene maximum) pertains to a climate characterized by high or rising temperatures. The Hypsithermal represents an interval of time when the average world temperature was greater than it is today.

Figure 4. Holocene alluvial chronologies. This figure was constructed by Knox (1983, figs. 3-9) to illustrate fluvial activity. As shown, alluviation and periods of relative stability are reported from areas of this study during the middle and late Holocene.

Figure 5. Holocene climate and history. This figure illustrates the general Holocene climate record in North Dakota and adjacent areas and places it in a cultural context. Bluemle and Clayton (1982, fig. 7) clearly note the relationship between climate and soil formation and erosion.

Figure 6. Chronostratigraphy of Oahe Formation stratotype. This generalized stratigraphic column illustrates the lithostratigraphic nomenclature proposed by Clayton and others (1976) for the Oahe Formation in North Dakota and suggested temporal context.

Figure 7. Soil horizon nomenclature. This figure illustrates a geologic section (M8298) and the soil nomenclature used in this report. A horizon = modern soil and includes organic mat $(\mathrm{O})$; $\mathrm{Ab}$ horizon $=$ buried soil $(=$ paleosol $)$; $\mathrm{C}$ horizon $=$ unaltered material.

Figure 8. General location of paleosol study localities in the central Great Plains. This figure illustrates the general distribution of project localities in the general context of the Great 
Plains as a vegetational province. The North Dakota (ND) localities are centered in grasslands ranging from open prairie to badlands terrain.

\section{THE HOLOCENE}

Figure 9. Stratotype of the Oahe Formation at the Riverdale Locality (from Clayton and others, 1976, fig. 4). Figure illustrates grain-size distribution, clay mineralogy, the carbonate content of the less-than-74- $\mu \mathrm{m}$ fraction and the calcite:dolomite ratio in the carbonate fraction. "V" in the clay minerals column indicates vermiculite.

Figure 10. Holocene climate history of North Dakota. In a southwest-to-northeast transect of North Dakota, Bluemle and Clayton (1982, fig. 8) illustrate landform stability and its relationship to climate. This project spans the latter part of the Wolf Creek Unstable Episode to the Mandan Stable Episode.

\section{METHODOLOGY (ANALYSES)}

\section{Localities, Sections, and Sampling}

Figure 11. Paleosol sampling at the Douglas Creek Locality. A stratigraphic section represents a specific sequence of layers of individual sediment units that are distinct from suband superjacent units. This figure illustrates Douglas Creek stratigraphic Section M8302. In this section, paleosols ( $\mathrm{Ab}$ horizons) alternate with sediments unaltered by soil-forming processes known as $\mathrm{C}$ horizons. The section measured here is on a rotated, but undistorted, block of the bluff. Paleosol horizons were flagged and measured. Samples were taken so that only uncontaminated sediments were removed from each layer. A soil column is shown on the left side of the figure representing Section M8302. This section consists of 31 distinct lithic units, including 15 paleosols, $15 \mathrm{C}$ horizons, and a modern soil.

\section{Texture}

Figure 12. Soil texture nomenclature. This ternary diagram illustrates the standard textural terms applied to soil and interbedded sediments. The dominant lithology in many of the study sections is silt loam.

Figure 13. Texture symbols. This figure illustrates the symbol patterns used for the range of lithologies identified in this study.

\section{Radiocarbon Dating}

Figure 14. Charcoal and lignite clasts in paleosols of the Douglas Creek Locality. This closeup in situ view shows carbon clasts used in petrographic examination for discriminating the difference between charcoal of the Oahe Formation and lignite of the Sentinel Butte Formation, a contrast in age of 57 or so million years. Charcoal samples were the main source of radiocarbon dates. 


\section{Stable Carbon}

Figure 15. Stable carbon isotope ratios of major components of terrestrial ecosystems (Boutton, 1991, fig. 1). The difference between $\mathrm{C}_{3}$ and $\mathrm{C}_{4}$ metabolic pathways reflects climates favored by different plants, which result in different $\delta^{13} \mathrm{C}$ values in paleosols, depending on changes in vegetation associated with changes in climate.

Figure 16. $\delta^{13} \mathrm{C}$ of organic matter in paleosols and sediments from Fort Hood Military Reservation in the southern Great Plains of central Texas (Boutton, 1996, fig. 10). This figure shows the variation in carbon derived from $\mathrm{C}_{4}$ plants through the last 12,000 years in comparison to global temperature variations (after Folland and others, 1991, fig. 7.1).

\section{Palynomorphs}

Figure 17. Holocene palynomorph abundance patterns. This figure illustrates the variation in general vegetation types through the Holocene from Terhell Pond, Mahnomen County, in northwestern Minnesota (McAndrews, 1966, pl. 5, in part). AP = trees and shrubs (arboreal pollen); NAP = anemophilous herbs (wind-pollinated, nonarboreal pollen); Ambrosia = ragweed; Artemisia $=$ wormwood; Gramineae $=$ grasses; Ostrya $=$ hombeam; Pice $a=$ spruce; Populus $=$ poplar; Quercus $=$ oak.

Figure 18. Project palynomorphs. Selected pollen and spores from project sediment samples show common taxa. Note that reworked Paleocene palynomorphs are also abundant. Micrographs are from Kroeger (written communication, 1997).

\section{Phytoliths}

Figure 19. Douglas Creek Locality phytoliths. This figure illustrates most of the morphological variation in phytoliths at project localities (derived from Fredlund and Tiezen, 1994, fig. 4) (see Douglas Creek Locality discussion for additional information).

Figure 20. Phytolith form and abundance at Douglas Creek Locality Section M8302. The phytolith percentages illustrated by these curves are from Fredlund (1997, unpublished report) (Table 7).

Figure 21. Douglas Creek Locality phytolith dendrogram. This cluster diagram was constructed by Beck (1997, unpublished report) using nonstandardized log-ratio data, which resulted in a cophenetic coefficient of 0.979 . Three cluster groups, A, B, and C, were identified.

\section{Mollusks}

Figure 22. Project pulmonate mollusks. The snails illustrated here are representative of the morphologies and taxa from project localities. 


\section{Paleosol Ages at the Douglas Creek Locality}

Figure 23. Paleosol radiocarbon dates for Douglas Creek Locality composite Section M8302. This graph illustrates the radiocarbon dates (as dots) and interpolated dates (as triangles) and the relative thickness of paleosols ( $\mathrm{x}$-axis). A subplot provides resolution for the closely spaced paleosols between 3100 and 3600 YBP.

Figure 24a-c. Figure 24a. Time series analysis of radiocarbon dates and paleosol thicknesses. Figure 24b. Lognormal distribution (Weibull probability) of paleosol thicknesses. Figure 24c. Lognormal distribution (Weibull probability) of paleosol radiocarbon dates.

\section{STUDY LOCALITIES}

Figure 25. Paleosol study localities in North Dakota. This figure illustrates the occurrence of project localities on a map of North Dakota counties. The eastern edge of drier conditions is represented by the Missouri Escarpment.

Figure 26. Late Quaternary summary section of the Little Missouri River badlands. This figure illustrates the lithostratigraphy and available radiocarbon dates as of Kuehn (1996, fig. 1) in the badlands of the Little Missouri River (compare Figure 91). This record covers the time interval considered in this report.

\section{Knutson Creek - Locality D}

Figure 27. Knutson Creek Locality D, Billings County, North Dakota. View downstream across Knutson Creek, a tributary of the Little Missouri River. The approximate age of Locality $D$ is illustrated relative to a temperature change curve for the Holocene. The name Locality $D$ is from Kuehn (1995).

Figure 28. Topographic location map of Knutson Creek Localities D and M (Medora Quadrangle). The numbers inside dashed squares, approximately $1.6 \mathrm{~km}$ on a side (a square mile), are township (T.) and range (R.) sections.

Figure 29. Air photo location map of Knutson Creek Localities D and M. The Knutson Creek localities are located near the west boundary of Theodore Roosevelt National Park in northern Billings County. The bright white and rugged surfaces represent the Paleocene-age badlands bounding the alluvial valley of Knutson Creek. Its confluence with the Little Missouri River is within $1.6 \mathrm{~km}(1 \mathrm{mi})$ of the east edge of this map.

Figure 30. Knutson Creek Locality D sections and terraces. View upstream of cutbank exposures. Badlands of the Paleocene-age Bullion Creek Formation, seen on the horizon, provide one source of alluvial sediments.

Figure 31. Knutson Creek Locality D sections and terraces. View downstream of worked cutbank exposures. Badlands of the Paleocene-age Bullion Creek and Sentinel Butte Formations 
are seen to the north and northeast. Terraces 4 to 1 represent successively younger terraces in Theodore Roosevelt National Park. Terrace 2 is not present at Locality D (Kuehn, 1995).

Figure 32. Section M8297 and sample horizons on Terrace 4. This figure illustrates the lithic units (Units 1-14) recognized in this sequence of paleosols and the sampled horizons (e.g., D-1) in June 1996 (Section M8297). Every unit was later resampled in October of 1996 (Section M8297a).

Figure 33. Correlation of Terrace 4 Sections M8297a and M8297b. This figure represents the correlation of lithologies between sections measured by Kuehn (1995; Section M8297b is modified from Kuehn fig. 30) and Hartman and Hartman (10/96, M8297a). This figure includes the sampled horizons and associated radiocarbon dates. Unit 11 (Kuehn, 1995; S1) is a mediumthick bed of massive silt, topped by a weakly developed soil (Entisol). A charcoal sample from near the top of the unit yielded a radiocarbon date. The S-numbers of Section M8297b are soil sequence numbers from Kuehn (1995), representing the basic alternation of Ab- and C-horizon couplets.

Figure 34. Texture analysis and nomenclature of Sections M8297 and M8297a. Each sediment sample is plotted by unit number onto a diagram of texture nomenclature. Most samples are modified loams, representing a high level of silt, some clay, and less sand.

Figure 35. Stable carbon data for Locality D on Terrace 4. Stable carbon values were derived from laboratory analyses by Boutton (written communication, 1996) and by WHOI (written communication, 1996, 1997). The values between these two groups of analyses are not directly comparable, as different processes and fractionation procedures were employed. $:$ Boutton's analyses used bulk samples specifically for stable carbon interpretation, whereas the WHOI sample was analyzed on a small charcoal sample to derive a radiocarbon date.

Figure 36. Section M8311 and sample horizons at Locality D on Terrace 2. This figure illustrates the lithic units (Units 1-10) recognized in this sequence of paleosols and the sampled horizons in June 1996 (Section M8311).

Figure 37. Texture analysis and nomenclature of Section M8311. All sediment samples are plotted by unit number onto a diagram of texture nomenclature. Most samples are modified loams, representing a high level of silt, with some clay and sand.

Figure 38. Stable carbon data of Section M8311 on Terrace 2 at Locality D. Stable carbon values were derived from laboratory analyses by Boutton (written communication, 1996).

Figure 39. Section M8312 and sample horizons on Terrace 1. This figure illustrates the lithic units (Units 1-5) recognized in this sequence of paleosols and the horizons sampled in June 1996 (Section M8312).

Figure 40. Texture analysis and nomenclature of Section M8312 on Terrace 1. Each sediment sample is plotted by unit number onto a diagram of texture nomenclature. The two samples are modified loams, representing a high level of silt, with some clay and less sand. 
Figure 41. Radiocarbon data of Section M8312 on Terrace 1 at Locality D. Radiocarbon values were derived from laboratory analyses by WHOI (written communication, 1997). The apparently poor date for Sample D-13 is likely due to the very small charcoal sample analyzed, allowing for few iterations.

Figure 42. Stable carbon data of Section M8312 on Terrace 1 at Locality D. Radiocarbon values were derived from laboratory analyses by Boutton and WHOI (written communications, 1996 and 1997, respectively).

\section{Knutson Creek - Locality M}

Figure 43. The Knutson Creek Locality M Section and terrace. View upstream of high cutbank exposures. Badlands of the Paleocene-age Bullion Creek and Sentinel Butte Formations, seen on the horizon, provide one source of alluvial sediments. The name Locality $M$ is from Kuehn (1995).

Figure 44. Section M8298 and sample horizons at Locality M on Terrace 4. This figure illustrates the lithic units (Units 1-25) recognized in this sequence of paleosols and the sampled horizons (e.g., M-1) in June 1996 (Section M8298). Every unit was later resampled in October of 1996 (Section M8298a).

Figure 45. Correlation of Terrace 4 Sections M8298a and M8298b. This figure represents the correlation of lithologies between sections measured by Kuehn (1995; Section M8298b is modified from Kuehn (fig. 32) and Hartman and Hartman (10/96, M8298a). This figure includes the sampled horizons. Insufficient carbon was found to derive radiocarbon dates. The S-numbers of Section M8298b are soil sequence numbers from Kuehn (1995), representing the basic alternation of $\mathrm{Ab}$ - and $\mathrm{C}$-horizon couplets.

Figure 46. Texture analysis and nomenclature of Sections M8298 and M8298a. Each sediment sample is plotted by unit number onto a diagram of texture nomenclature. Most samples are modified loams, representing a high level of silt, some clay, and less sand.

Figure 47. Stable carbon data of Locality $\mathrm{M}$ on Terrace 4. Stable carbon values were derived from laboratory analyses by Boutton (written communication, 1996). Boutton's analyses used bulk samples specifically for stable carbon interpretation. Note that the stable carbon curves for Localities $\mathrm{D}$ and $\mathrm{M}$ on Terrace 4 are comparable in shape, but with a variation in values. This comparison does suggest that Locality $\mathrm{M}$ may be similar to Locality $\mathrm{D}$ in age.

\section{Knife River Indian Villages - Elbee Bluff Locality}

Figure 48. The Elbee Bluff Locality and Terrace A at the Knife River Indian Villages National Historic Site, Mercer County, North Dakota. View across terrace toward Knife River and Elbee Bluff Locality. The approximate age of the Elbee Bluff Locality is illustrated relative to a temperature change curve for the Holocene. The name Elbee Bluff is from Reiten (1983). The interval of time represented by the geologic sections of the project is indicated on the temperature variation curve for the Holocene (from Folland and others, 1991). 
Figure 49. Topographic location map of the Elbee Bluff Locality (Stanton and Stanton SE Quadrangles).

Figure 50. Air photo location map of the Elbee Bluff Locality. The locality is located near the west boundary of the Knife River Indian Villages National Historic Site in eastern Mercer County. The confluence of the alluvial valley of the meandering Knife River with the Missouri River is within $3 \mathrm{~km}$ (1.9 mi) of the south edge of the map.

Figure 51. Elbee Bluff Locality, Mercer County, North Dakota. View downstream across the Knife River, a tributary of the Missouri River. This figure illustrates the location of Section M8299 and level of Terrace A (of Reiten, 1983). As this bluff face is actively eroding, the conformation of the exposures changes frequently.

Figure 52. Geochronologic map showing the age of floodplain deposits of the Knife River Indian Villages National Historic Site (after Reiten, 1983, pl. 3). The location of the Elbee Bluff Locality is highlighted.

Figure 53. Profile sketch of the Elbee Bluff Locality showing the relationships of terraces, paleosols, and radiocarbon samples (e.g., UGA, SMU) (after Reiten, 1983, fig. 30).

Figure 54. Section M8299 and sample horizons at the Elbee Bluff Locality. This figure illustrates the lithic units (Units 1-14) recognized in this sequence of paleosols and the sampled horizons (e.g., A-1) in June 1996 (Section M8299). Every unit was later resampled in October of 1996 (Section M8299a).

Figure 55. Elbee Bluff Locality sections and terrace. View upstream of worked cutbank exposures. Section M8299 was sampled and described in June 1996, and Section M8299a was studied in October of the same year. Section M8299a is on a large, undistorted block that has rotated away from the slump face.

Figure 56. Correlation of Terrace A Sections M8299a and M8299b. This figure represents the correlation of lithologies between sections measured by Reiten (1983; Section M8299b is modified from Reiten fig. 30) and Hartman and Hartman (10/96, M8299a). This figure includes the sampled horizons and associated radiocarbon dates (* and S6 and S7 are dates from Reiten, 1983). A charcoal sample from near the top of the unit yielded a radiocarbon date. The Snumbers of Section M8299b represent buried soils numbered by Reiten (1983).

Figure 57. Texture analysis and nomenclature of Sections M8299 and M8299a. Each sediment sample is plotted by unit number onto a diagram of texture nomenclature. Many of the samples are modified loams, representing a high level of silt, some clay, and less sand. Unlike other localities, silty clay sediments are also relatively common.

Figure 58. Stable carbon data of the Elbee Bluff Locality. Stable carbon values were derived from laboratory analyses by Boutton (written communication, 1996) and by WHOI (written communication, 1997). The values between these two groups of analyses are not directly comparable, as different processes and fractionation procedures were employed. Boutton's 
analyses used bulk samples specifically for stable carbon interpretation, whereas the WHOI sample was analyzed on a small charcoal sample to derive a radiocarbon date.

\section{Douglas Creek Locality}

Figure 59. The Douglas Creek Locality on Lake Sakakawea (Missouri River), McLean County, North Dakota. View of upland surface across tributary valley of Missouri River encompassing, below, the Douglas Creek sections. The approximate age of the Douglas Creek Locality is illustrated relative to a temperature change curve for the Holocene. The Douglas Creek Locality is named after the North Dakota Douglas Creek State Game Management Area, which includes this site. The bedrock of the upland surface is the Paleocene-age Sentinel Butte Formation.

Figure 60. Topographic location map of the Douglas Creek Locality (Emmet SE Quadrangle).

Figure 61. Air photo location map of the Douglas Creek Locality. The Douglas Creek Locality is located near the north shore of Lake Sakakawea on south-facing exposures. The white border around the peninsula is the ever-changing shoreline of the lake. This figure is derived from a 1995 air photo of the Douglas Creek State Game Management Area.

Figure 62. Douglas Creek Locality sections. View across swash zone of eroding cutbank exposures. Significant geologic sections include M8301-M8304, with other M-numbered geological observations (see Abbreviations, p. 13). Section M8302 represents the thickest section, and all radiocarbon dates are correlated to it. The Holocene Oahe Formation locally overlies either glacial deposits of the Pleistocene Coleharbor Formation or the Paleocene Sentinel Butte Formation (about $57 \mathrm{Ma}$ ). This shoreline has since been ravaged by the high waters of Lake Sakakawea, but note that a condensed paleosol section is seen above the till to the west.

Figure 63. Oahe (Holocene) and Sentinel Butte (Paleocene) formational contact at the Douglas Creek Locality. This view shows a slumped section of the Sentinel Butte Formation with a distorted and thinned bed of the Garrison Creek lignite. The Douglas Creek paleosols of the Oahe Formation can be seen trending to the south, down the valley. This exposure represents the headwall of the tributary and paleosols. Carbon clasts from the Garrison Creek lignite bed create a source of contamination in radiocarbon dating, stable carbon analysis, and total organic carbon analysis.

Figure 64. Correlation of Douglas Creek Locality sections. This correlation profile includes the four main sections at this locality (M8301-M8304), and all of the paleosols were traced laterally across the valley. The thickest paleosols are in the center of the valley (Section M8302). Note that the thickness of the beds lateral to Section M8303 does not decrease. The first buried paleosol is used as a datum for portraying the occurrence of the measured sections. Radiocarbon dates are shown with their sample numbers where their respective samples were collected. All numbers on the sides of the sections represent unit numbers (e.g., Section M8302 contains 31 units). 
Figure 65. Douglas Creek Locality Section M8302. This section represents the mostanalyzed paleosol sequence at the Douglas Creek Locality.

Figure 66. Section M8302 and sample horizons at the Douglas Creek Locality. This figure illustrates the lithic units (Units 1-31) recognized in this sequence of paleosols and the sampled horizons (e.g., DC-1 to DC-16) in June 1996. Paleosols in other sections were directly correlated with this section. All radiocarbon dates are correlated with Section M8302, including multiple analyses on charcoal or bone from the same sample.

Figure 67. Bone fragments in paleosols from the Douglas Creek Locality. This closeup in situ view illustrates Bison bone found in a few layers. A number of Bison teeth and bone fragments were found as float in shoreline deposits. In situ bones did not represent good material for radiocarbon dating, as the collagen was effectively replaced.

Figure 68. Texture analysis profile of Section M8302. The percentage of clay, silt, and sand is shown as histograms for the 15 paleosols and modern soil of Section M8302. Certain trends in grain size are noted, but their significance is uncertain (increase in silt through Unit 11 and possible fining-upwards of the sediment in the remaining paleosols).

Figure 69. Texture analysis and nomenclature of Section M8302. Each sediment sample is plotted by unit number onto a diagram of texture nomenclature. All samples are modified loams, representing a high level of silt and some clay and sand.

Figure 70. Pebble lens in $\mathrm{C}$ horizon at the Douglas Creek Locality. This view includes a pebble lens at the base of a $\mathrm{C}$ horizon. Pebble lenses are sporadic, but common, at the Douglas Creek Locality. Lenses include pebbles undoubtedly derived from local glacial till sources and represent higher-flow regimes during alluvial sedimentation.

Figure 71. Stable carbon data of Section M8302. Stable carbon values were derived from laboratory analyses by Boutton (written communication, 1996), UAZ (written communication, 1997), and WHOI (written communications, 1996, 1997). The values between these three groups of analyses are not directly comparable, as different processes and fractionation procedures were employed. Boutton's analyses used bulk samples specifically for stable carbon interpretation and are believed to be the most reliable for the purposes of this project, while the UAZ and WHOI samples were analyzed on bone and small charcoal samples to derive radiocarbon dates. All stable carbon values are correlated with Section M8302, including multiple analyses on charcoal or bone from the same sample. The Geochron (e.g., LS-1 and LS-2) stable carbon value was based on a bone sample and differs remarkably from other data. The $\delta^{13} \mathrm{C}$ values are plotted as occurring at the midpoint of each paleosol. The Boutton data (Texas A\&M University) are believed to be the most reliable. A decrease in $\mathrm{C}_{3}$ vegetation is indicated by the Boutton curve, which suggests a warming trend toward Unit 5.

Figure 72. Section M8302 stable carbon values correlated with radiocarbon dates. Stable carbon' values were derived as described in the explanation for Figure 31 . The curve shown here is from the analyses by Boutton (written communication, 1996). All radiocarbon dates are correlated with Section M8302 (as in Figure 66), including multiple analyses on charcoal or bone 
from the same sample. The Geochron (e.g., LS-1) radiocarbon date was based on a bone sample using a non-AMS dating technique (see Radiocarbon Dating section of this report).

Figure 73. Douglas Creek Locality Section M8301. This section represents the farthestwest sequence of paleosols studied at the Douglas Creek Locality.

Figure 74. Texture analysis profile of Section M8301. The percentage of clay, silt, and sand is shown for the 12 paleosols and modern soil of Section M8301. Certain trends in grain size are noted in this figure (e.g., overall reduction in the amount of sand), but their significance is uncertain.

Figure 75. Texture analysis and nomenclature of Section M8301. Each sediment sample is plotted by unit number onto a diagram of texture nomenclature. All samples are modified loams, representing a high level of silt, some clay, and less sand.

Figure 76. Douglas Creek Locality Section M8303.

Figure 77. Texture analysis profile of Section M8303. The percentage of clay, silt, and sand is shown for the 15 paleosols, $16 \mathrm{C}$ horizons, and modern soil of Section M8303. Certain trends in grain size are noted in this figure (e.g., overall increase in the amount of silt in paleosols), but their significance is uncertain. Also, $C$ horizons appear consistently to contain less silt than paleosols.

Figure 78. Texture analysis and nomenclature of Section M8303. Each sediment sample is plotted by unit number onto a diagram of texture nomenclature. All samples are modified loams, representing a high level of silt, some clay, and less sand.

Figure 79. Douglas Creek Locality Section M8304. This section represents the farthesteast sequence of paleosols studied at the Douglas Creek Locality. The stylized bone indicates an important bone horizon.

Figure 80. Texture analysis profile of Section M8304. The percentage of clay, silt, and sand is shown for the seven paleosols and modern soil of Section M8304.

Figure 81. Texture analysis and nomenclature of Section M8304. Each sediment sample is plotted by unit number onto a diagram of texture nomenclature. All samples are silt loams, representing nearly the same amount of silt and clay, with variation in the amount of sand.

\section{Riverdale Locality}

Figure 82. The Riverdale Locality on Lake Sakakawea (Missouri River), McLean County, North Dakota. View of bluff face and upland surface along east edge of lake north of Garrison Dam. No dates are specifically available for the Riverdale Section, but it is known to span the Holocene (see Figures 24 and 83). A bone sample from the Pick City Member (Sample R-7) lacked collagen for dating. The name Riverdale Locality is after the town of Riverdale, adjacent to the dam. 
Figure 83. Topographic location map of the Riverdale Locality (Riverdale North Quadrangle).

Figure 84. Air photo location map of the Riverdale Locality. The Riverdale Locality is above the eastern shoreline of Lake Sakakawea on steep west-facing exposures. The locality occurs within the North Dakota Wolf Creek Game Management Area (WCGMA).

Figure 85. Suggested age relations of the Oahe Formation at its type section, including interpretations of (A) mean annual temperature, (B) precipitation, (C) slopewash erosion on steep slopes, (D) eolian deposition on gentle slopes, and (E) periods of conspicuous soil formation (from Clayton and others, 1976, fig. 7).

Figure 86. Texture analysis and nomenclature of Section M8300. Each sediment sample is plotted by unit number onto a diagram of texture nomenclature. Samples are silt-rich, with small amounts of clay and sand.

Figure 87. General section and stable carbon curve and data for the Riverdale Locality. A bone sample from the Pick City Member had insufficient collagen to produce a radiocarbon date (UAZ, written communication, 1997). Stable carbon values were derived from laboratory analyses by Boutton (written communication, 1996).

\section{Fryburg Area - Locality C}

Figure 88. Fryburg area Locality C, Billings County, North Dakota. View along badlands-upland surfaces. Locality $\mathrm{C}$ represents the Leonard paleosol of the Aggie Brown Member of the Oahe Formation. The Leonard paleosol has been dated as 10,740 \pm 120 years old (see Figure 90). The name Locality $C$ is from Kuehn (1995; see also, 1996).

Figure 89. Topographic location map of Locality C (Fryburg NW Quadrangle). Locality C is on the east edge of Theodore Roosevelt National Park, north-northwest of Fryburg in northern Billings County.

Figure 90. Air photo location map of Locality C.

Figure 91. Locality C Section M8291a. This figure illustrates the 2.3-m section described by Kuehn (1995, fig. 18) that includes Sample C-1 from the Leonard Paleosol of the Aggie Brown Member of the Oahe Formation. 


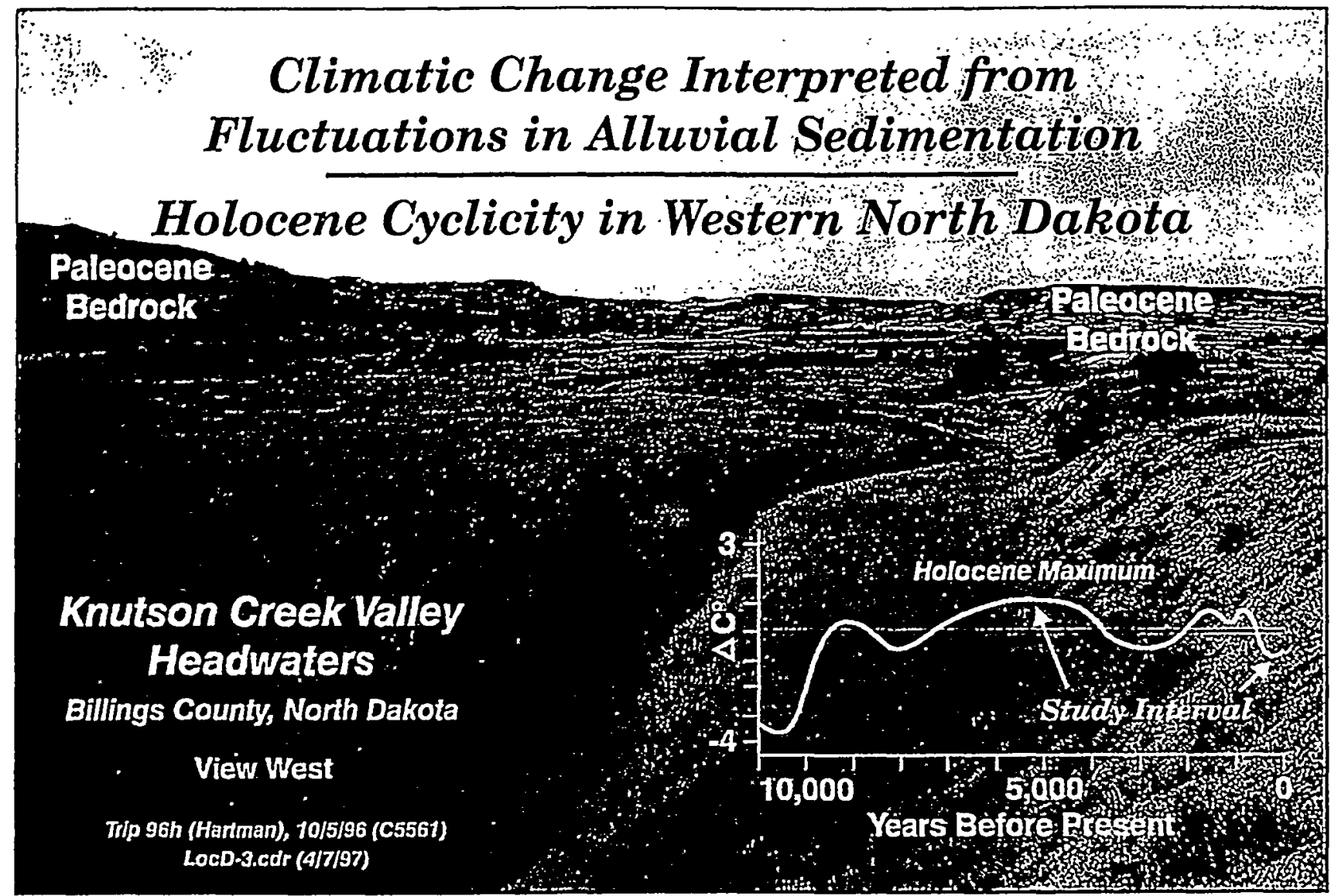

Figure 1. Holocene cyclicity in western North Dakota - Climate change interpreted from fluctuations in alluvial sedimentation. This figure shows the valley of the headwaters of Knutson Creek, a typical tributary of the Little Missouri River, dominated by alluvial sedimentation and bounded by 56-to 58-million-yearold nonmarine strata, also deposited predominantly by alluvial processes. This study includes analyses of paleosol sequences ranging from over 5000 to 145 years 


\section{Natural Climatic Variation \\ Influenced by Human Activity}
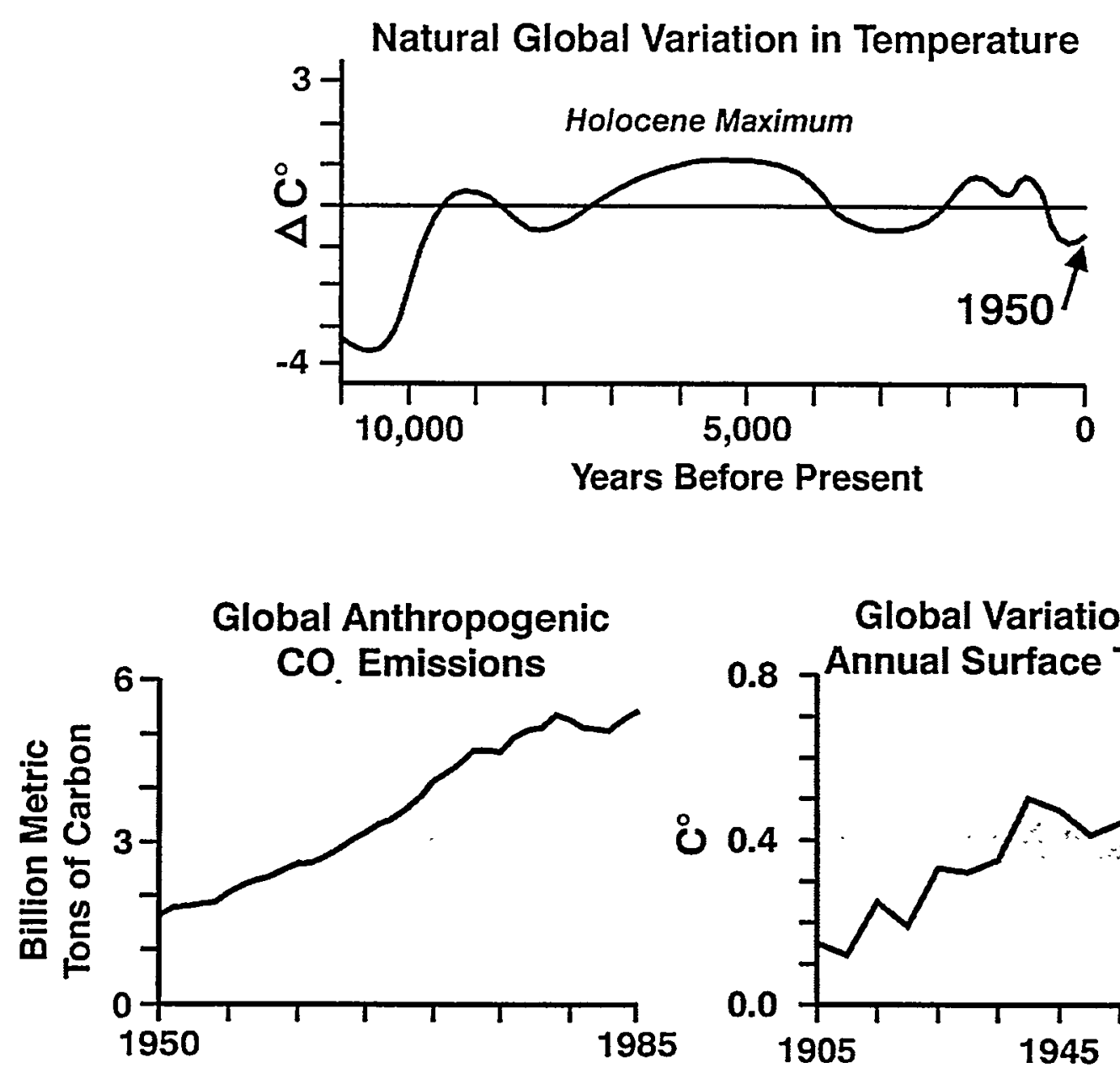

From Folland and others (1991) and Councll on Environmental Quality (1989)

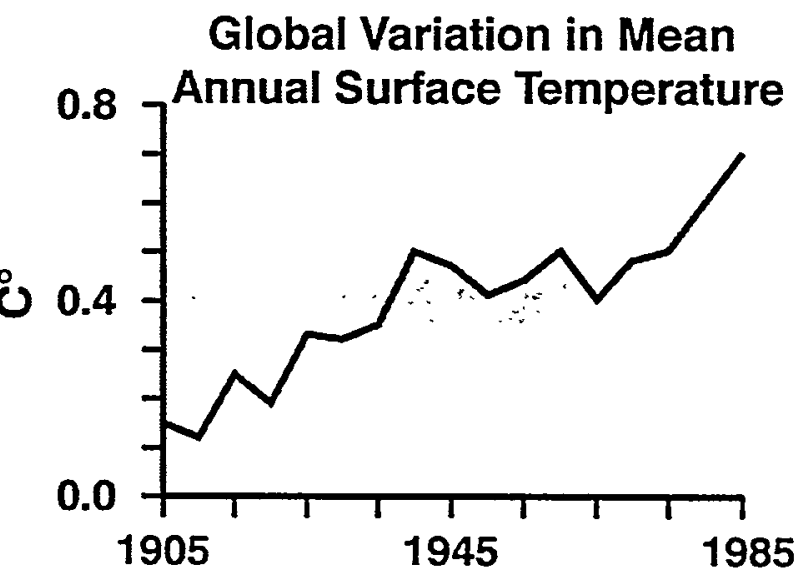

Power2.cdr (12/29/97)

Figure 2. Natural climatic variation influenced by human activity. Variation in climate,

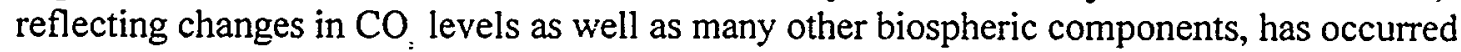
continuously throughout billions of years of earth history. Of concern today is the exacerbation of normal climate change as a by-product of human industry. Understanding the history and extent of climate change and the magnitude of human impact is necessary to develop effective policy on resource management and utilization. 


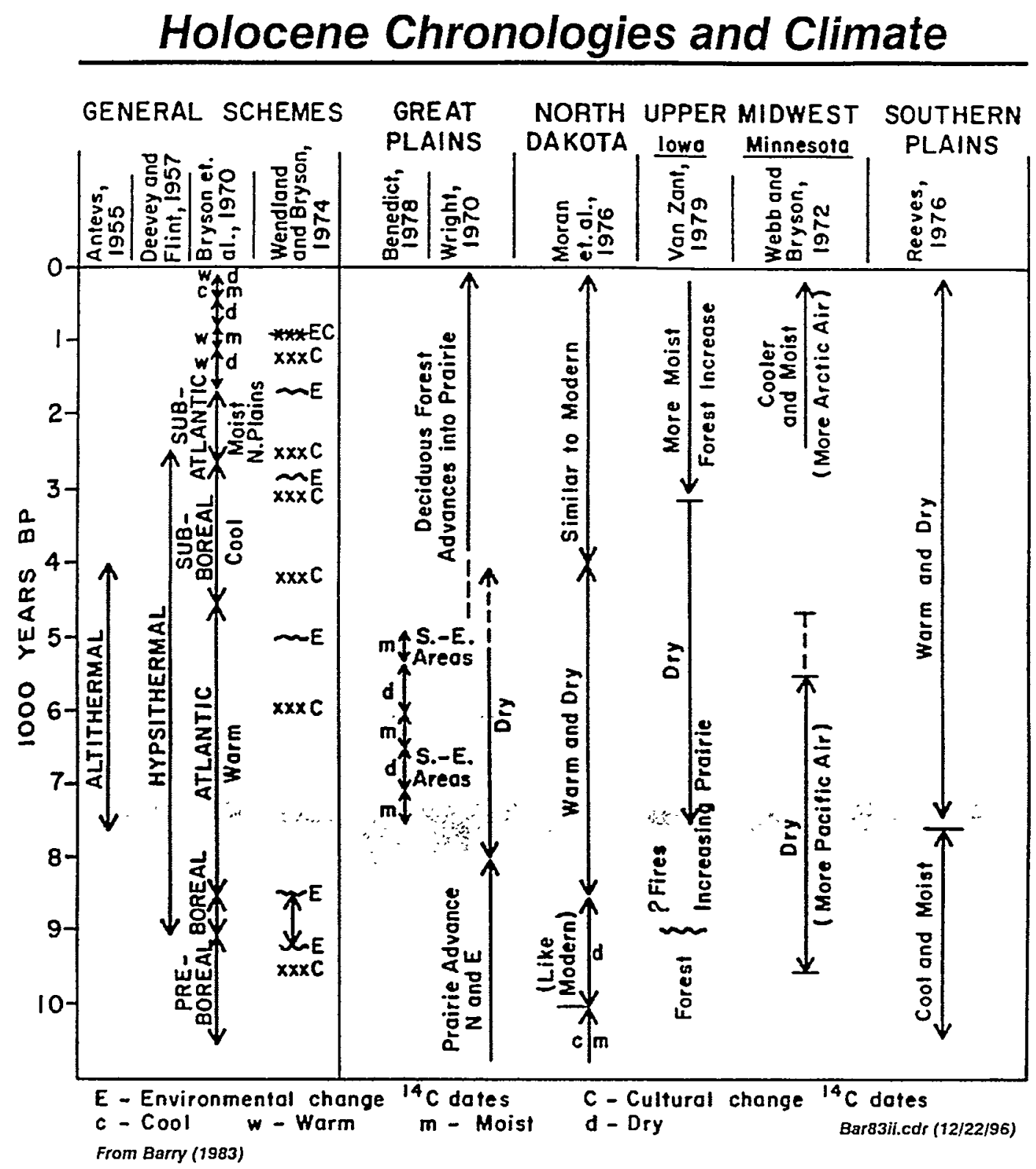

Figure 3. Holocene chronologies and climate. This figure summarizes chronological data for Great Plains areas during the Holocene, as of Barry (1983, table II). Climate change summaries for this interval have been changing rapidly as the number of tightly controlled radiometric dates increases the resolution of interpretation. The work by Barry (1983) provides a broadscale understanding of the Holocene climate. Altithermal (Holocene maximum) pertains to a climate characterized by high or rising temperatures. The Hypsithermal represents an interval of time when the average world temperature was greater than it is today. 


\section{Holocene Alluvial Chronologies}

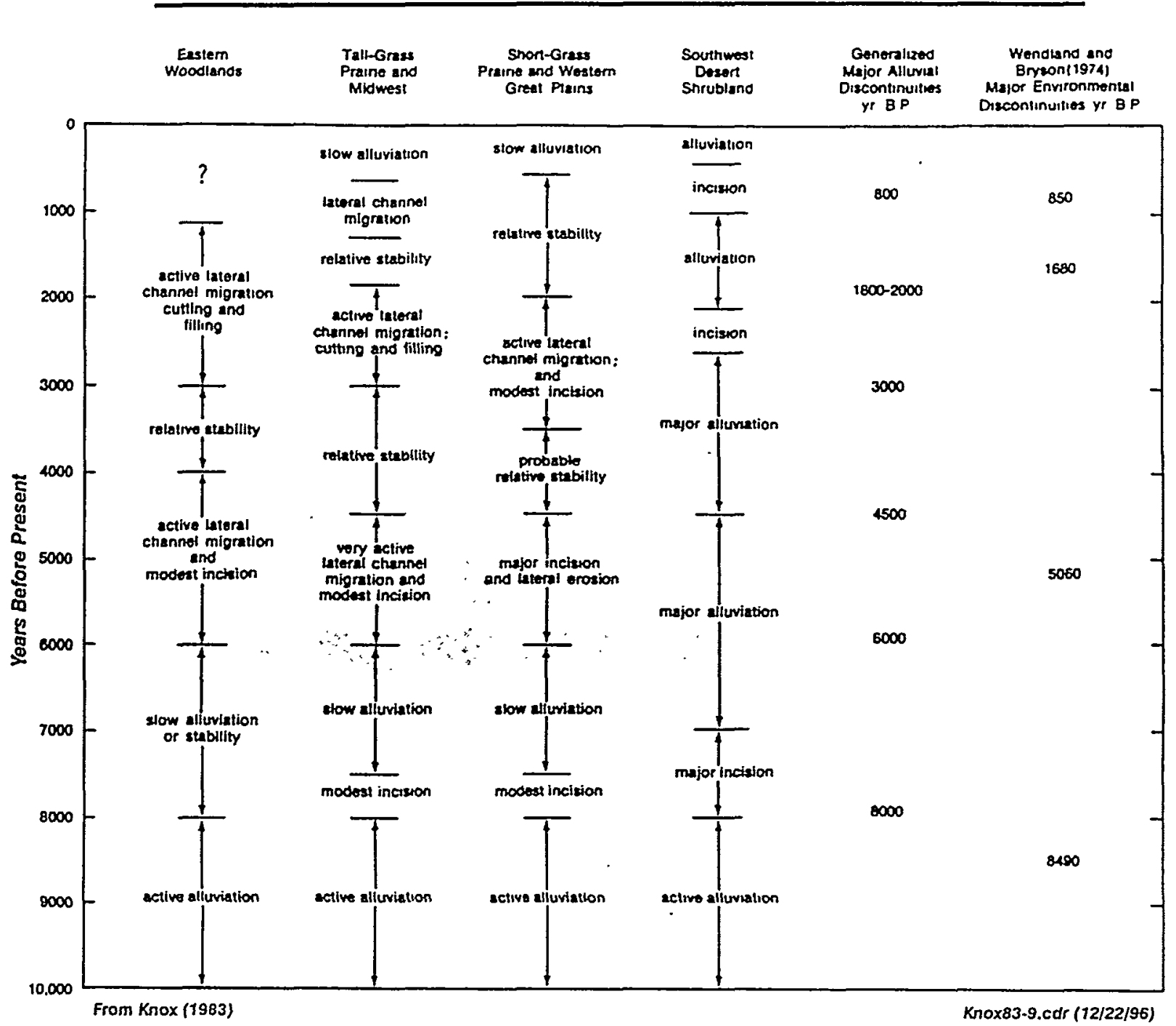

Figure 4. Holocene alluvial chronologies. This figure was constructed by Knox (1983, figs. 3-9) to illustrate fluvial activity. As shown, alluviation and periods of relative stability are reported from areas of this study during the middle and late Holocene. 


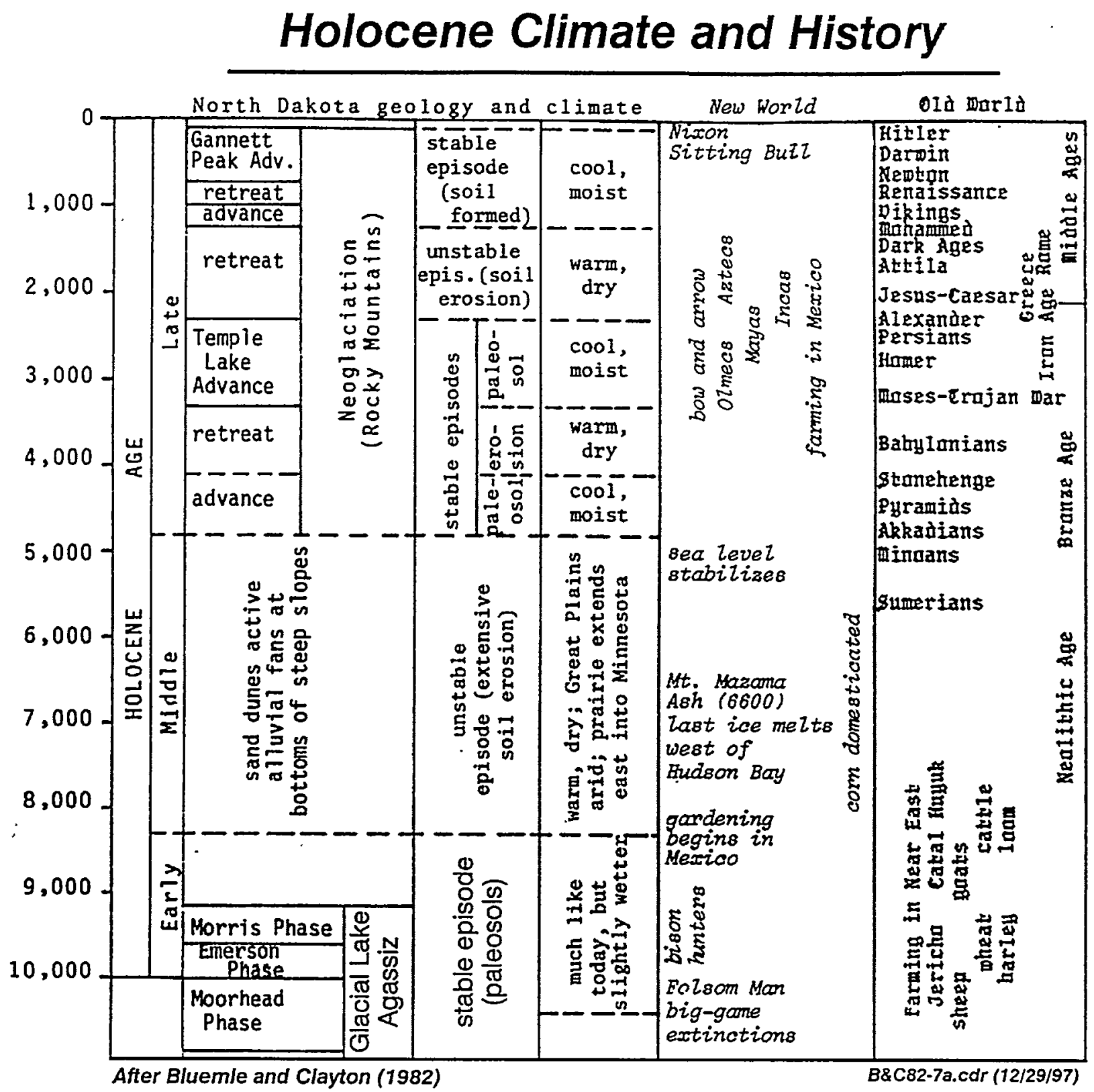

Figure 5. Holocene climate and history. This figure illustrates the general Holocene climate record in North Dakota and adjacent areas and places it in a cultural context. Bluemle and Clayton (1982, fig. 7) clearly note the relationship between climate and soil formation and erosion. 


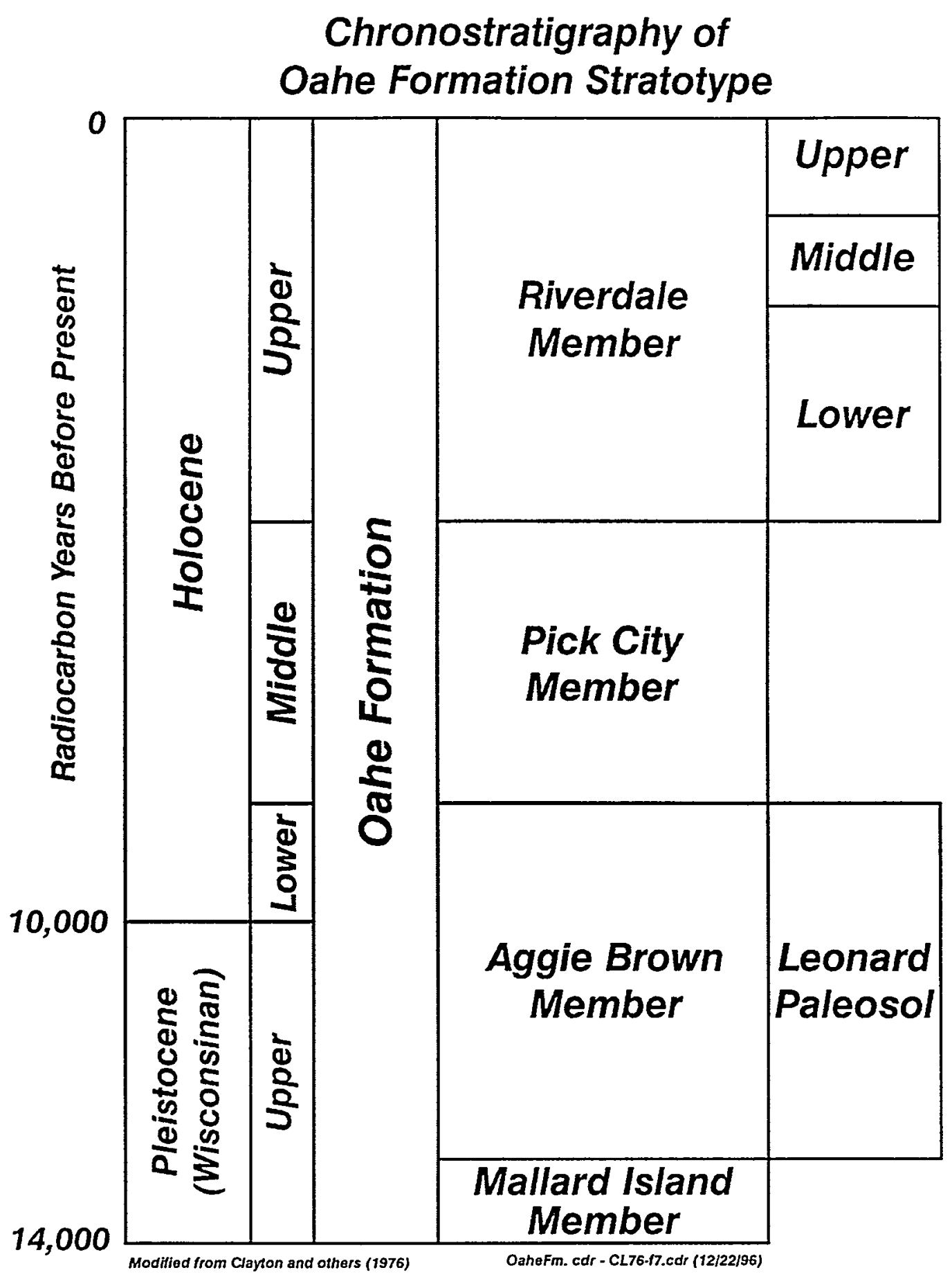

Figure 6. Chronostratigraphy of Oahe Formation stratotype. This generalized stratigraphic column illustrates the lithostratigraphic nomenclature proposed by Clayton and others (1976) for the Oahe Formation in North Dakota and suggested temporal context. 


\section{Soil Horizon Nomenclature}

\section{Locality M, Section M8298, Terrace 4 Oahe Formation}

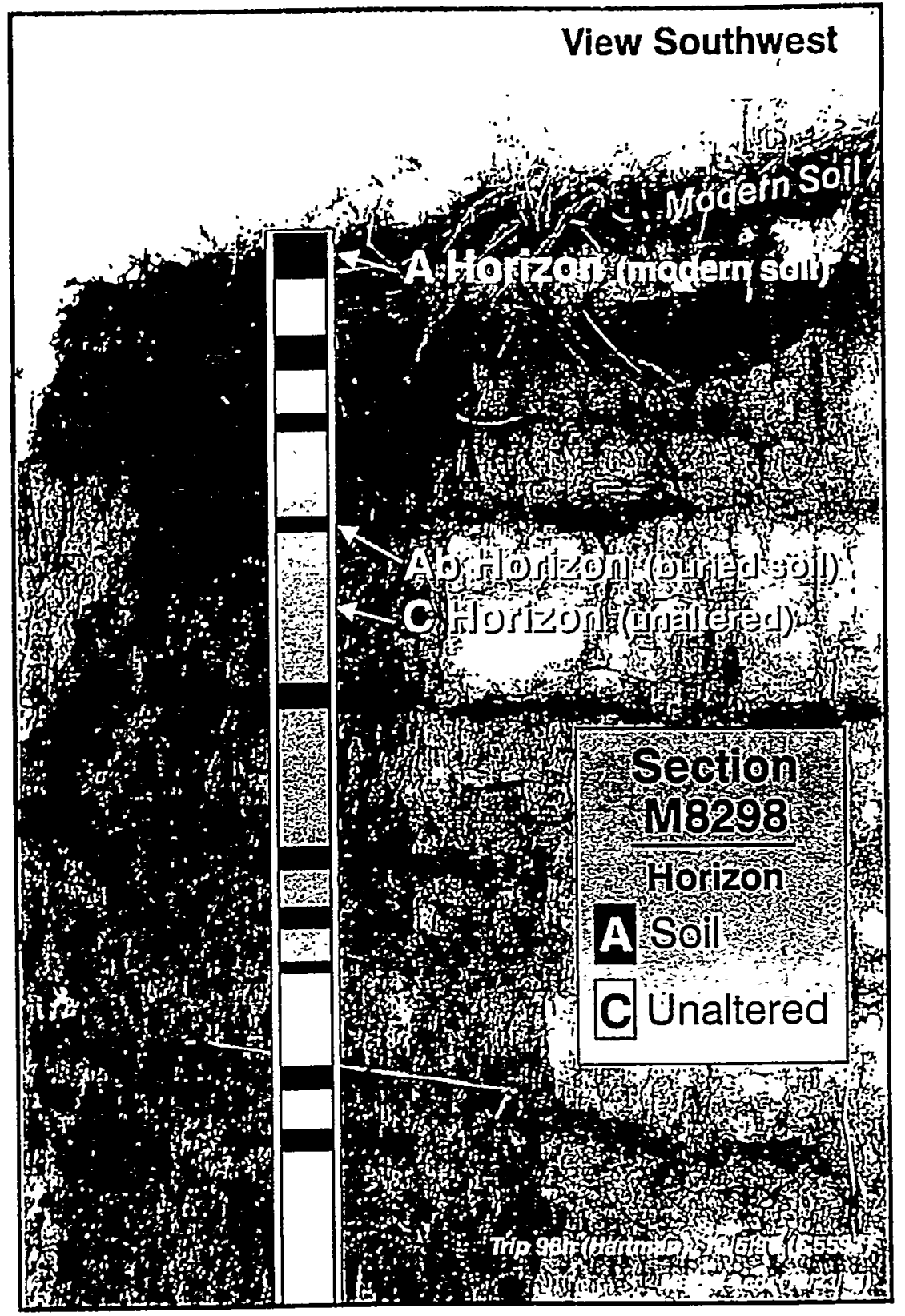

Figure 7. Soil horizon nomenclature. This figure illustrates a geologic section (M8298) and the soil nomenclature used in this report. $A$ horizon $=$ modern soil and includes organic mat $(\mathrm{O}) ; \mathrm{Ab}$ horizon $=$ buried soil $(=$ paleosol $) ; \mathrm{C}$ horizon $=$ unaltered material. 


\section{General Location of Paleosol Study Localities}

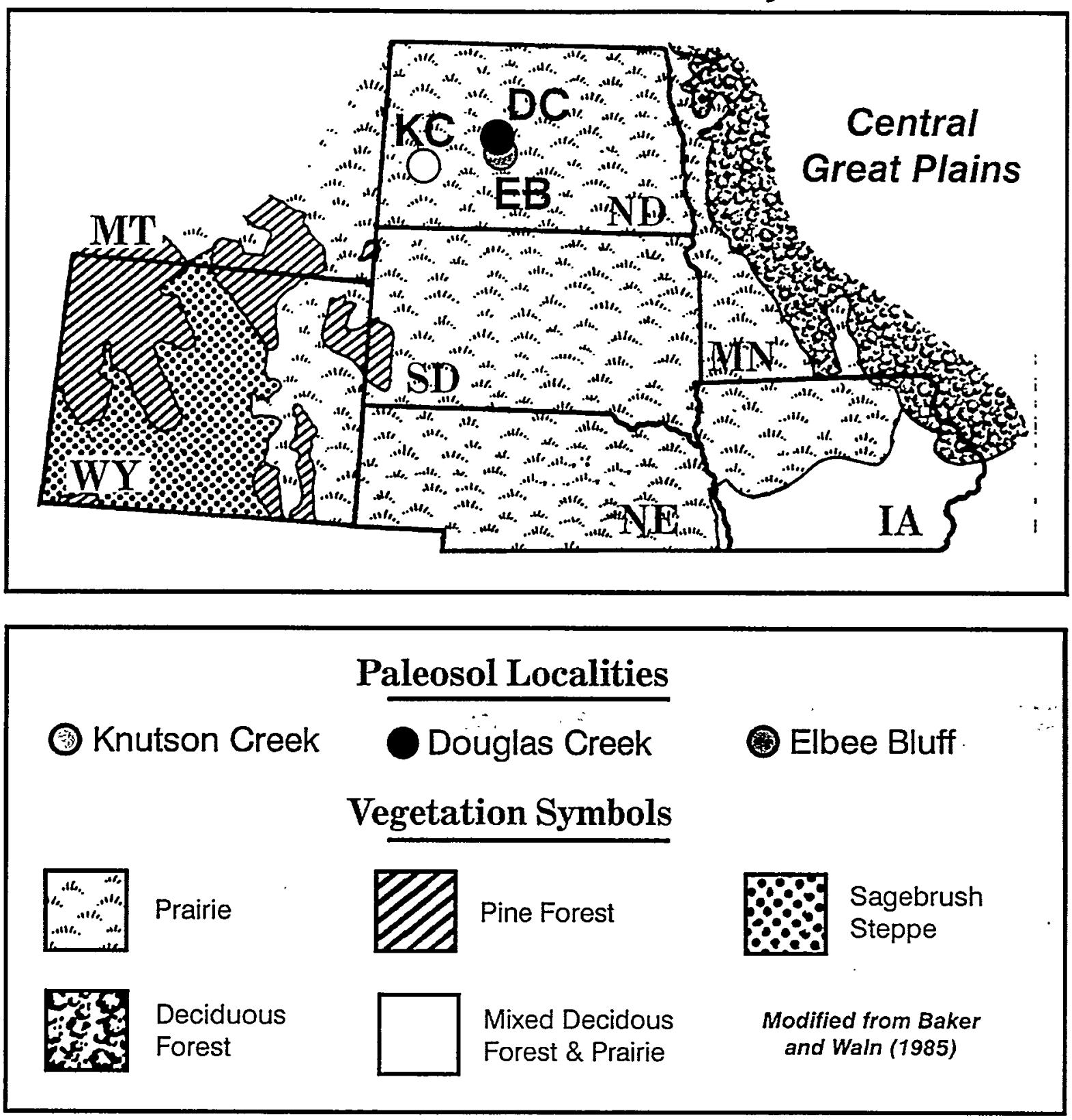

PRA-1.cdr (4/5/97)

Figure 8. General location of paleosol study localities in the central Great Plains. This figure illustrates the general distribution of project localities in the general context of the Great Plains as a vegetational province. The North Dakota (ND) localities are centered in grasslands ranging from open prairie to badlands terrain. 


\section{Oahe Formation Stratotype Riverdale Locality}

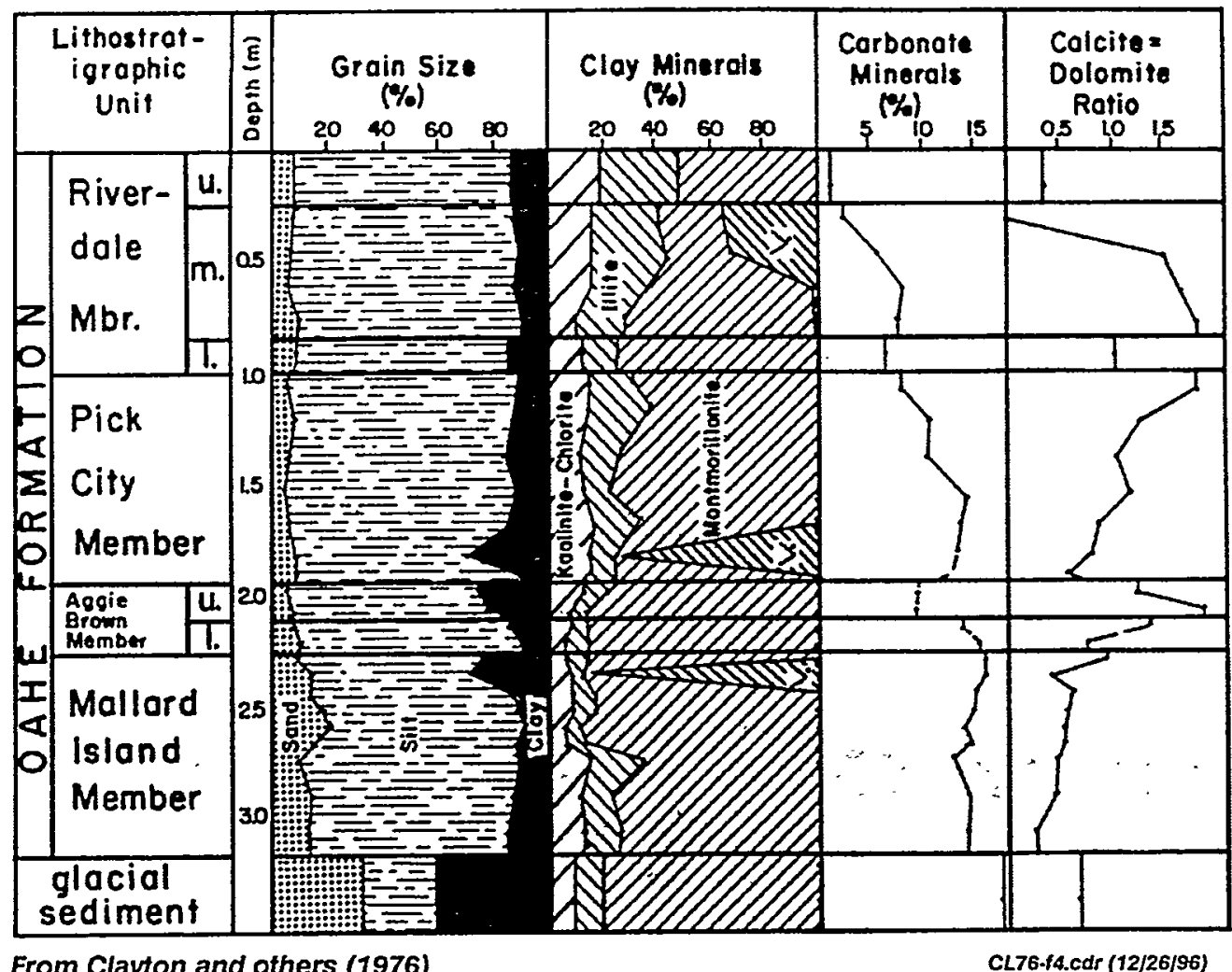

Figure 9. Stratotype of the Oahe Formation at the Riverdale Locality (from Clayton and others, 1976, fig. 4). Figure illustrates grain-size distribution, clay mineralogy, the carbonate content of the less-than-74- $\mu \mathrm{m}$ fraction and the calcite:dolomite ratio in the carbonate fraction. "V" in the clay minerals column indicates vermiculite. 


\section{Holocene Climate History of North Dakota}

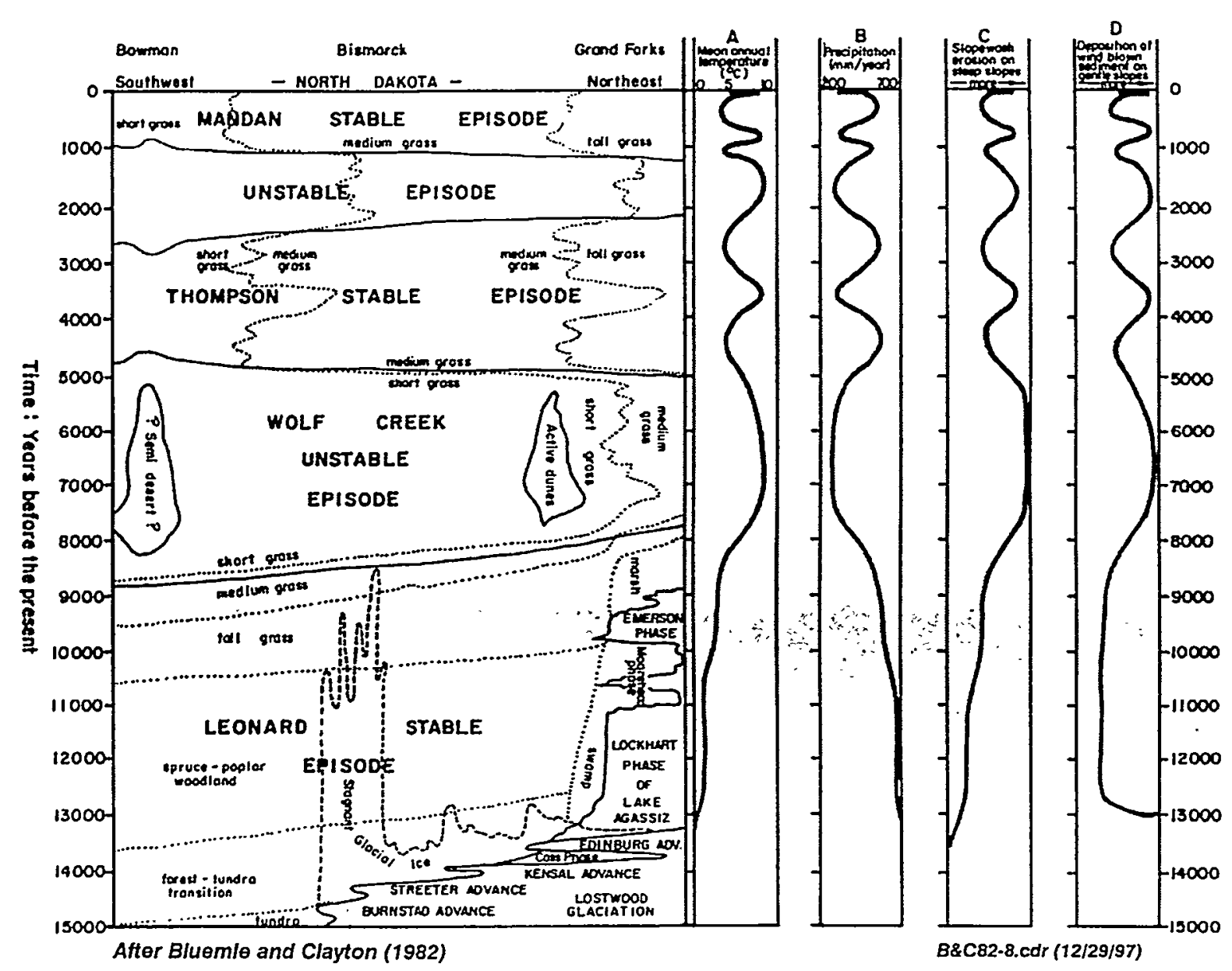

Figure 10. Holocene climate history of North Dakota. In a southwest-to-northeast transect of North Dakota, Bluemle and Clayton (1982, fig. 8) illustrate landform stability and its relationship to climate. This project spans the latter part of the Wolf Creek Unstable Episode to the Mandan Stable Episode. 


\section{Locality Sampling and Section Measuring}

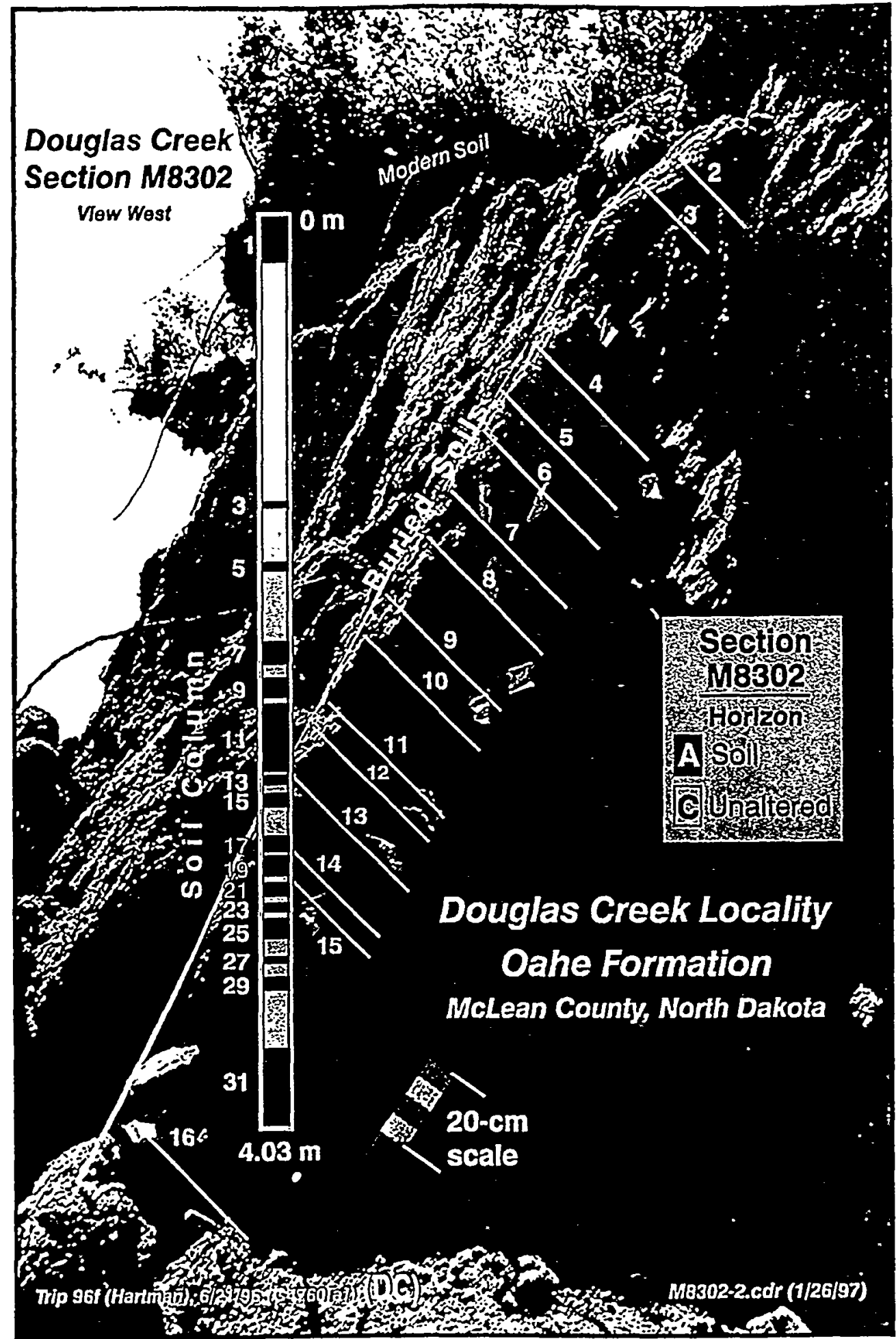

Figure 11. Paleosol sampling at the Douglas Creek Locality. A stratigraphic section represents a specific sequence of layers of individual sediment units that are distinct from sub- and superjacent units. This figure illustrates Douglas Creek stratigraphic Section M8302. In this section, paleosols (Ab horizons) alternate with sediments unaltered by soilforming processes known as $C$ horizons. The section measured here is on a rotated, but undistorted, block of the bluff. Paleosol horizons were flagged and measured. Samples were taken so that only uncontaminated sediments were removed from each layer. A soil column is shown on the left side of the figure representing Section M8302. This section consists of 31 distinct lithic units, including 15 paleosols, $15 \mathrm{C}$ horizons, and a modern soil. 


\section{Soil Texture Nomenclature}

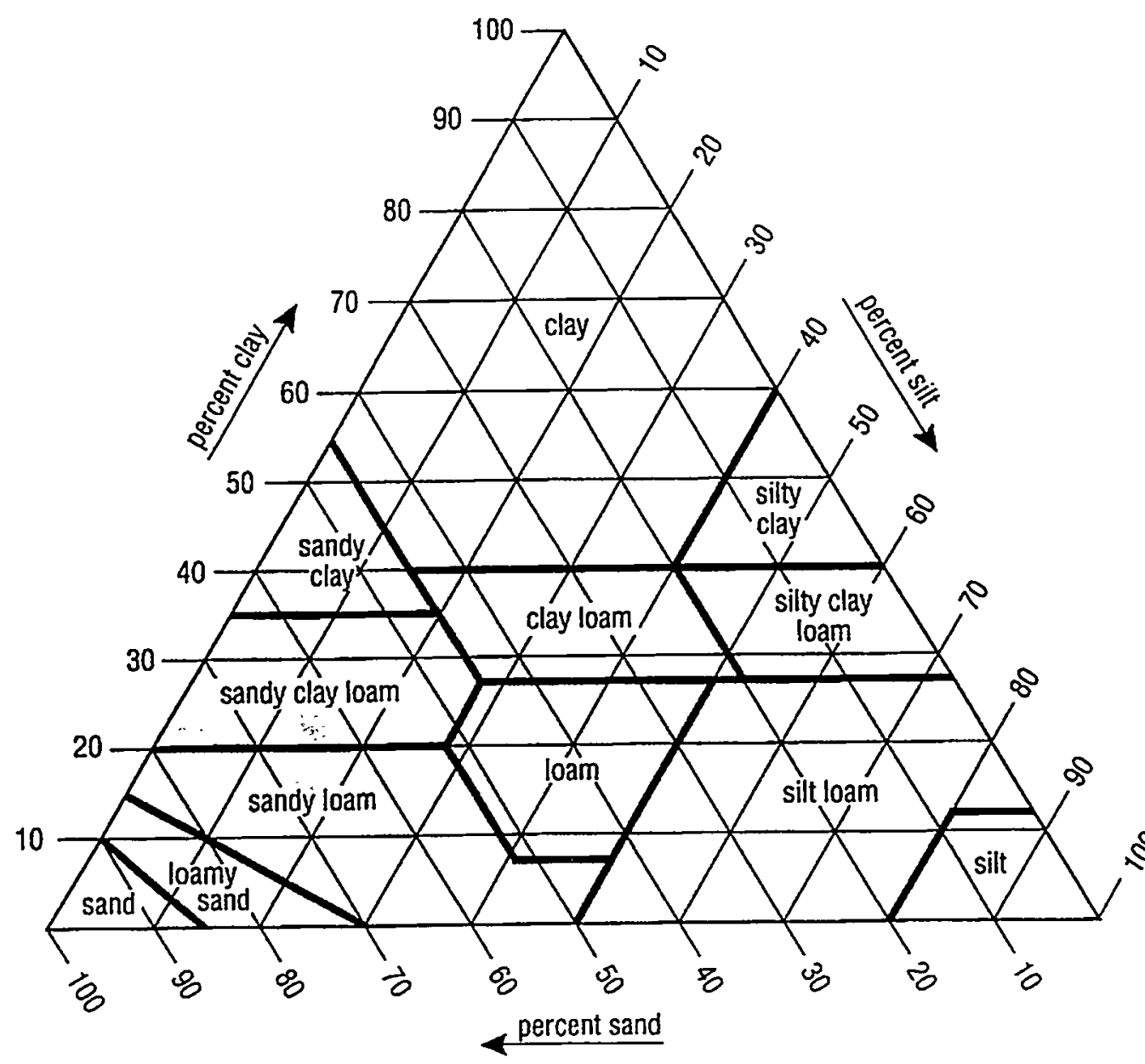

From Soil Survey Manual (1993)

Soils.cdr (3/26/97)

Figure 12. Soil texture nomenclature. This ternary diagram illustrates the standard textural terms applied to soil and interbedded sediments. The dominant lithology in many of the study sections is silt loam. 


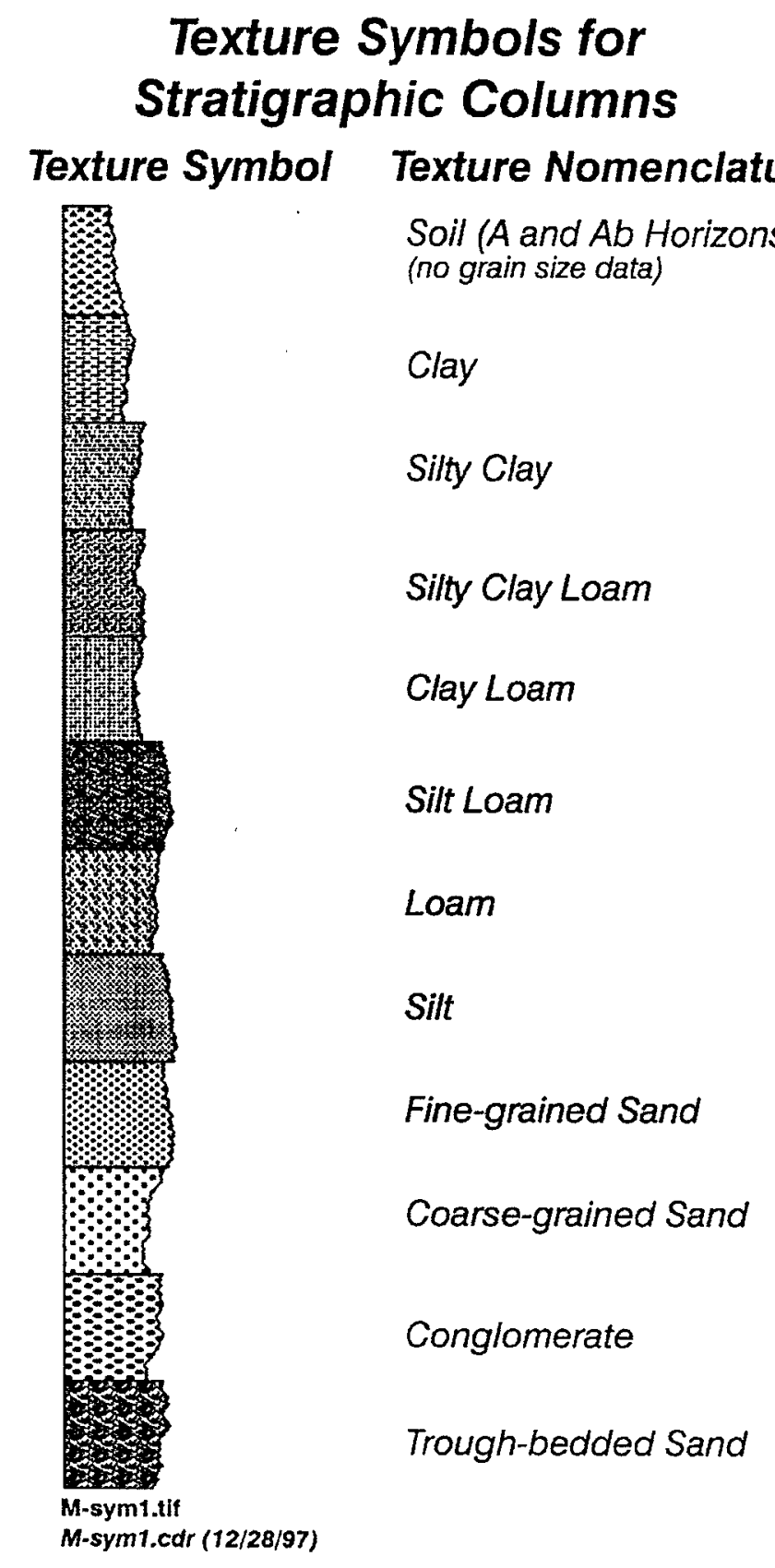

Figure 13. Texture symbols. This figure illustrates the symbol patterns used for the range of lithologies identified in this study. 


\section{Douglas Creek Locality - Paleosol Carbon Clasts}

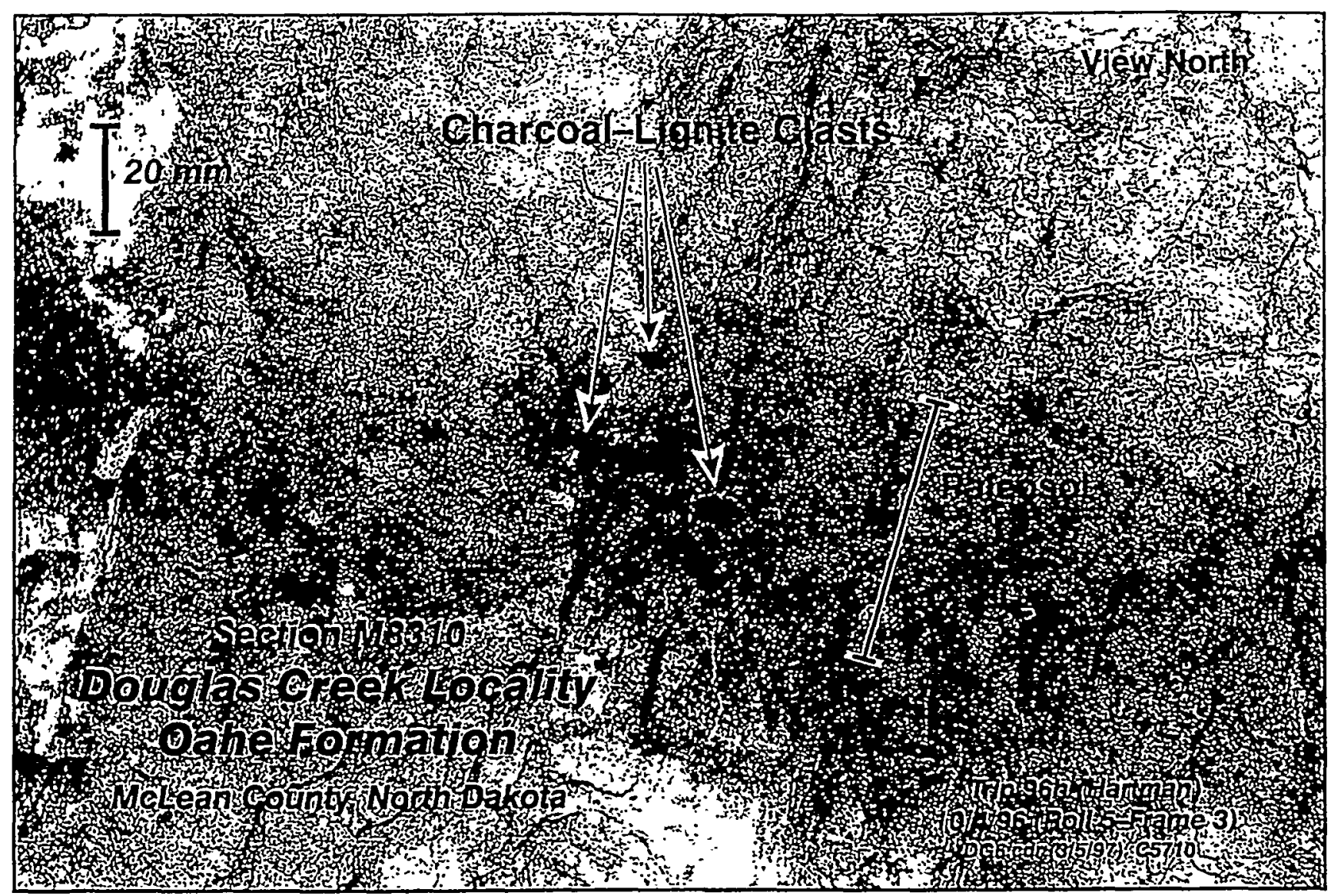

Figure 14. Charcoal and lignite clasts in paleosols of the Douglas Creek Locality. This closeup in situ view shows carbon clasts used in petrographic examination for discriminating the difference between charcoal of the Oahe Formation and lignite of the Sentinel Butte Formation, a contrast in age of 57 or so million years. Charcoal samples were the main source of radiocarbon dates. 


\section{Stable Carbon Isotope Ratios in Major Terrestrial Ecosystems}

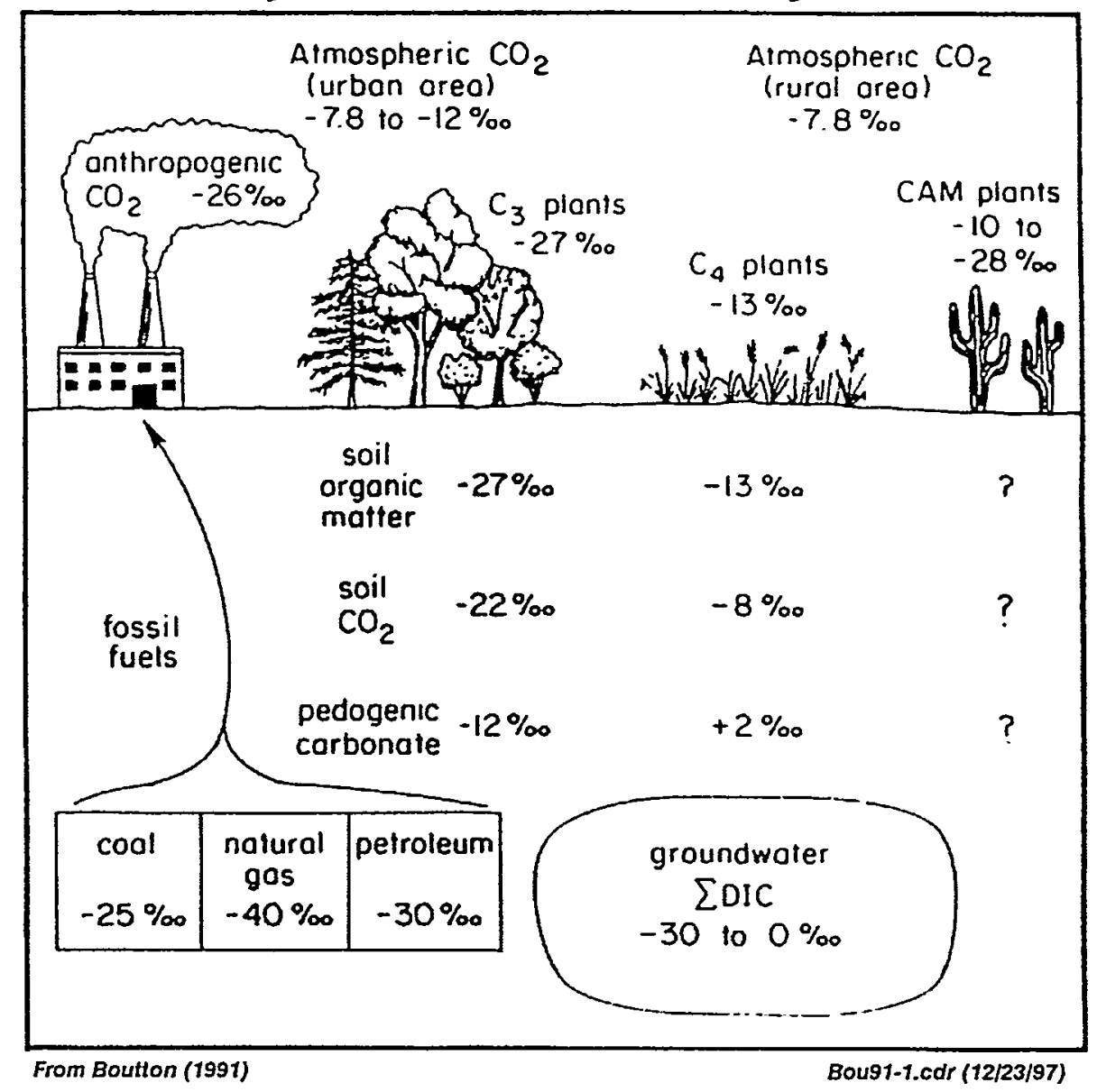

Figure 15. Stable carbon isotope ratios of major components of terrestrial ecosystems (Boutton, 1991, fig. 1). The difference between $C$ and $\mathrm{C}$. metabolic pathways reflects climates favored by different plants, which result in different $\delta^{\prime \prime} \mathrm{C}$ values in paleosols, depending on changes in vegetation associated with changes in climate. 


\section{$\delta^{13} \mathrm{C}$ Organic Matter in Paleosols and Holocene Mean Global Temperature Variations}

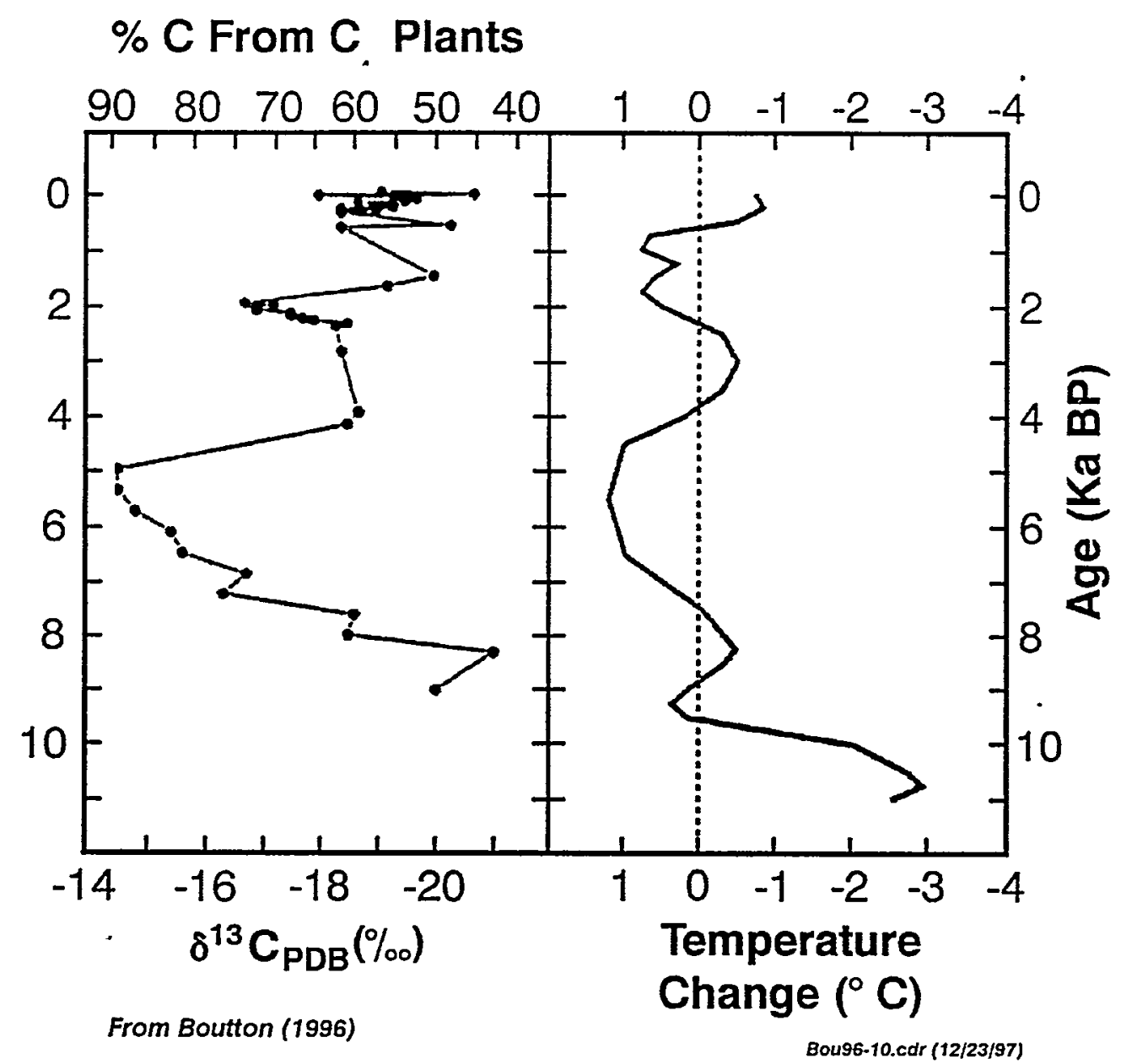

Figure 16. $\delta 13 \mathrm{C}$ of organic matter in paleosols and sediments from Fort Hood Military Reservation in the southern Great Plains of central Texas (Boutton, 1996, fig. 10). This figure shows the variation in carbon derived from $C$. plants through the last 12,000 years in comparison to global temperature variations (after Folland and others, 1991, fig. 7.1). 


\section{Holocene Palynomorph Patterns}

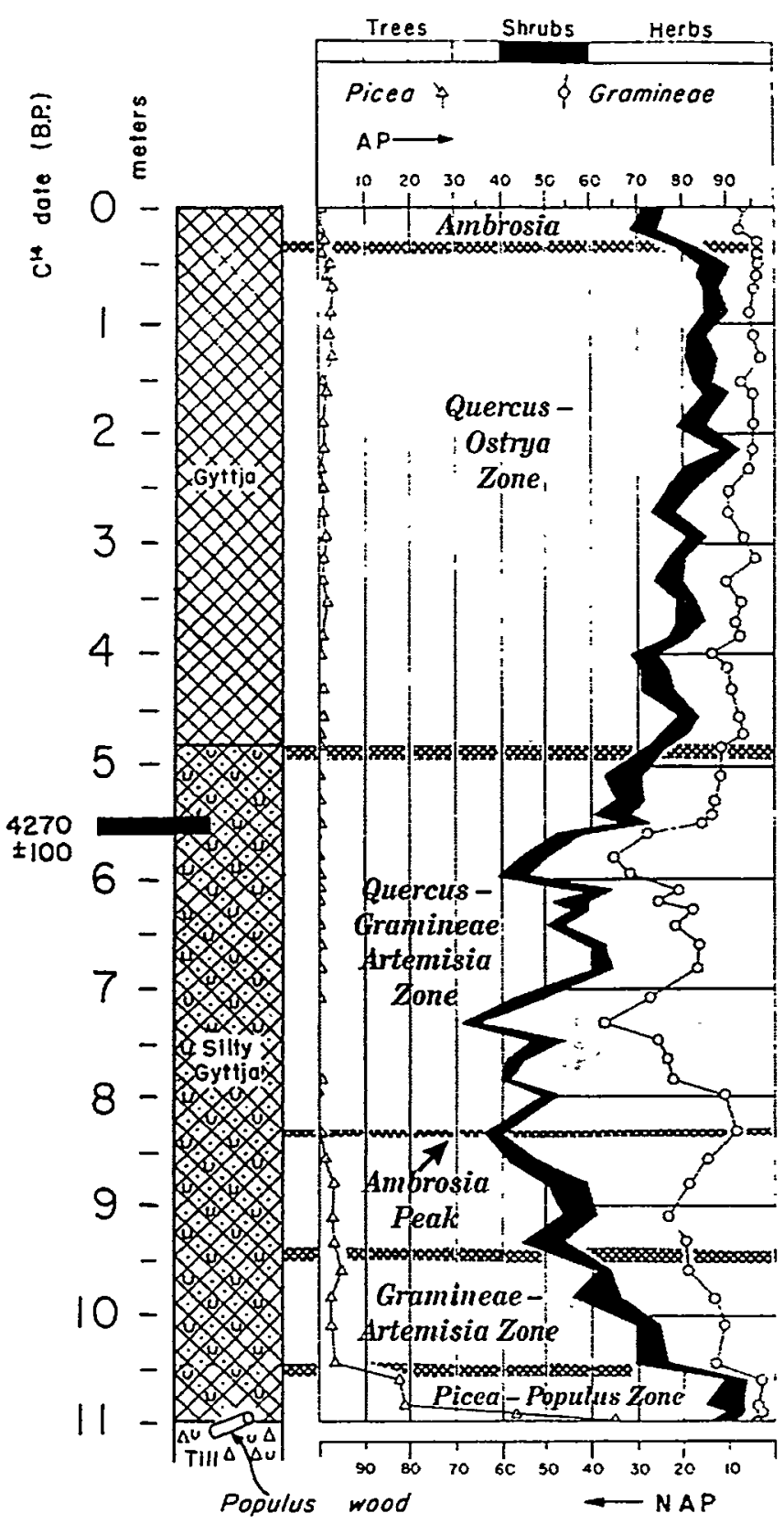

From McAndrews (1966)

MCA66-5.codr (12/23/97)

Figure 17. Holocene palynomorph abundance patterns. This

figure illustrates the variation in general vegetation types through the Holocene from Terhell Pond, Mahnomen County, in northwestern Minnesota (McAndrews, 1966, pl. 5, in part). AP = trees and shrubs (arboreal pollen); NAP = anemophilous herbs (wind-pollinated, nonarboreal pollen); Ambrosia = ragweed; Artemisia $=$ wormwood; Gramineae $=$ grasses; Ostrya $=$ hornbeam; Picea $=$ spruce $;$ Populus $=$ poplar Quercus $=$ oak. 


\section{Project Palynomorphs}

\section{Knutson Creek Localities}
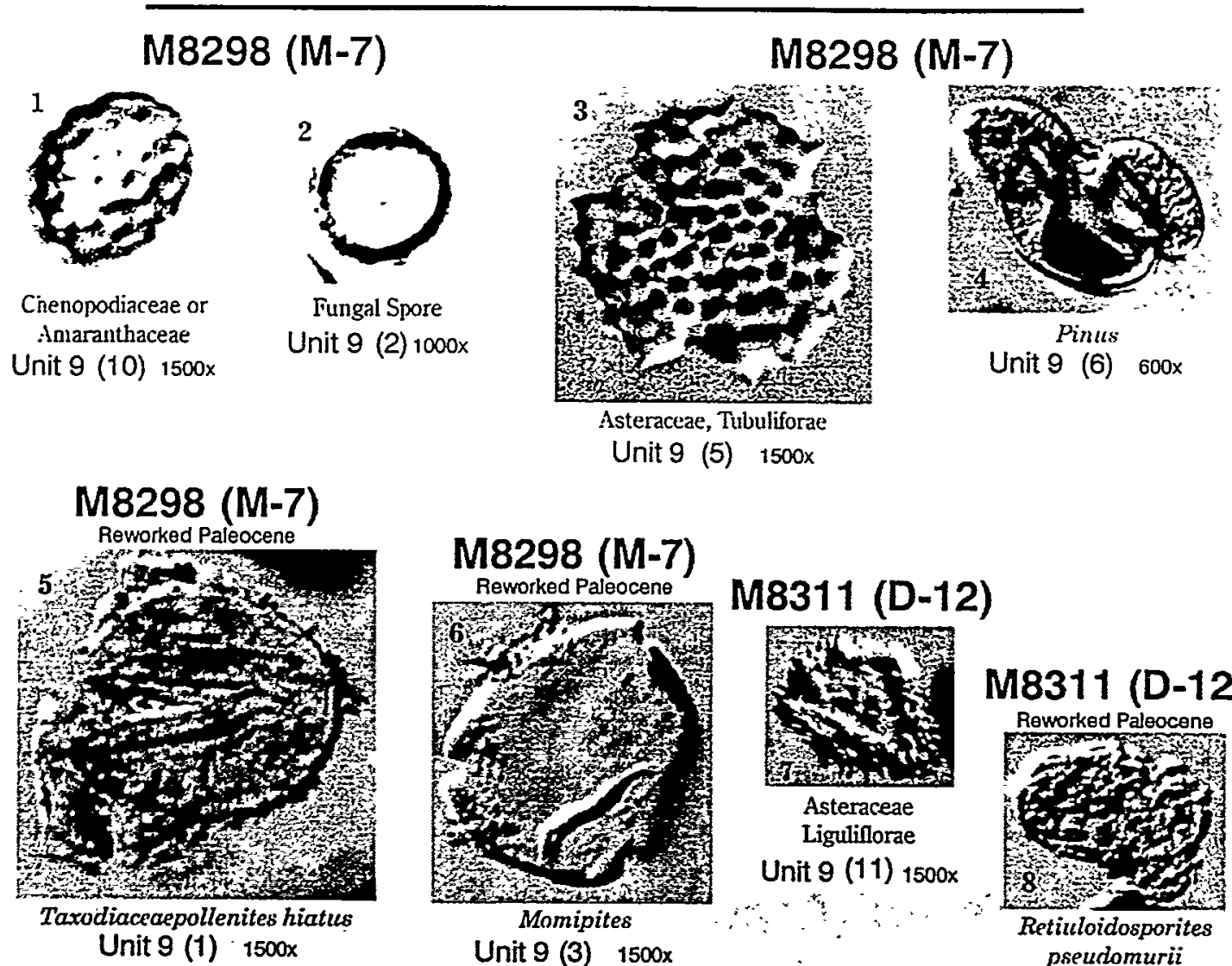

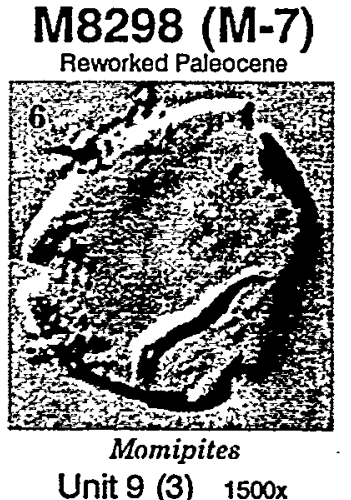

Unit 9 (3) $1500 x$

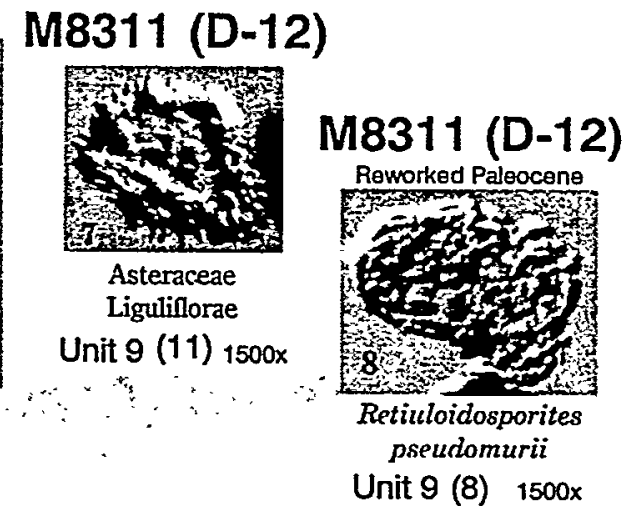

\section{Elbee Bluff Locality}
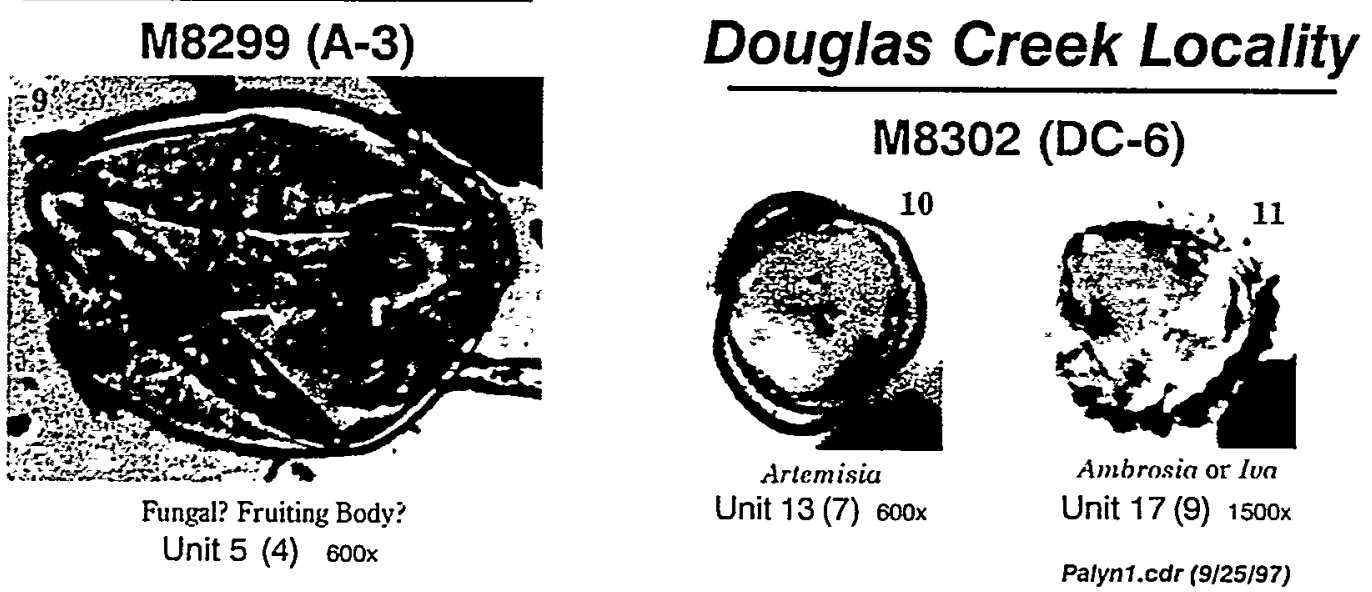

Figure 18. Project palynomorphs. Selected pollen and spores from project sediment samples show common taxa. Note that reworked Paleocene palynomorphs are also abundant. Micrographs are from Kroeger (written communication, 1997). 


\section{Douglas Creek Locality Phytoliths}
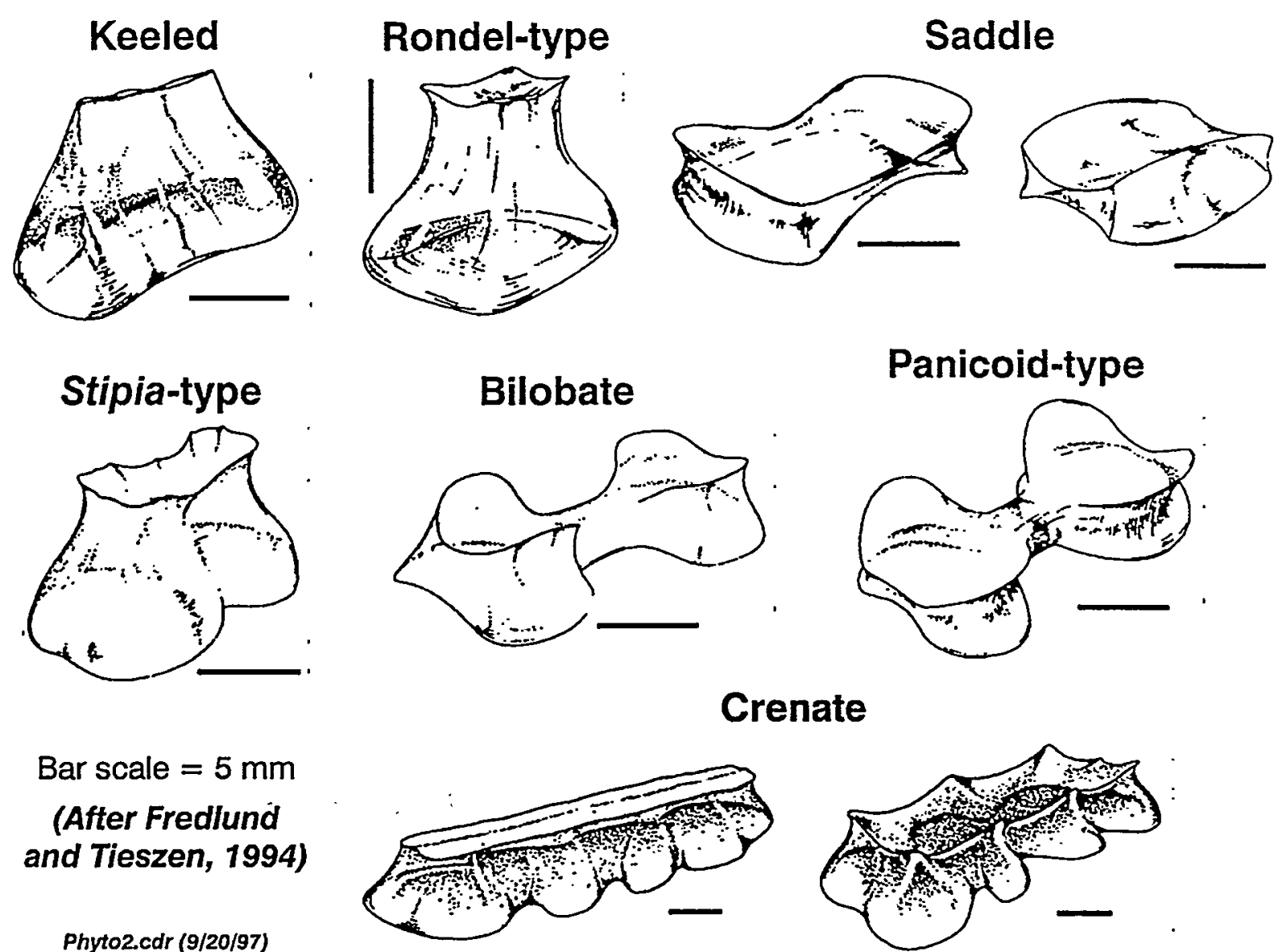

Phyto2.cdr (9/20/97)

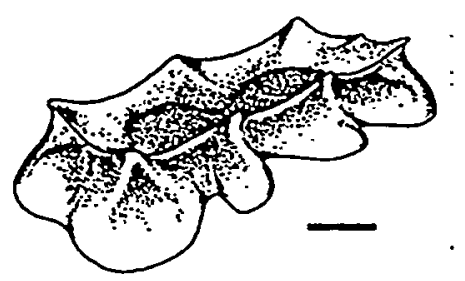

Figure 19. Douglas Creek Locality phytoliths. This figure illustrates most of the morphological variation in phytoliths at project localities (derived from Fredlund and Tiezen, 1994, fig. 4) (see Douglas Creek Locality discussion for additional information). 


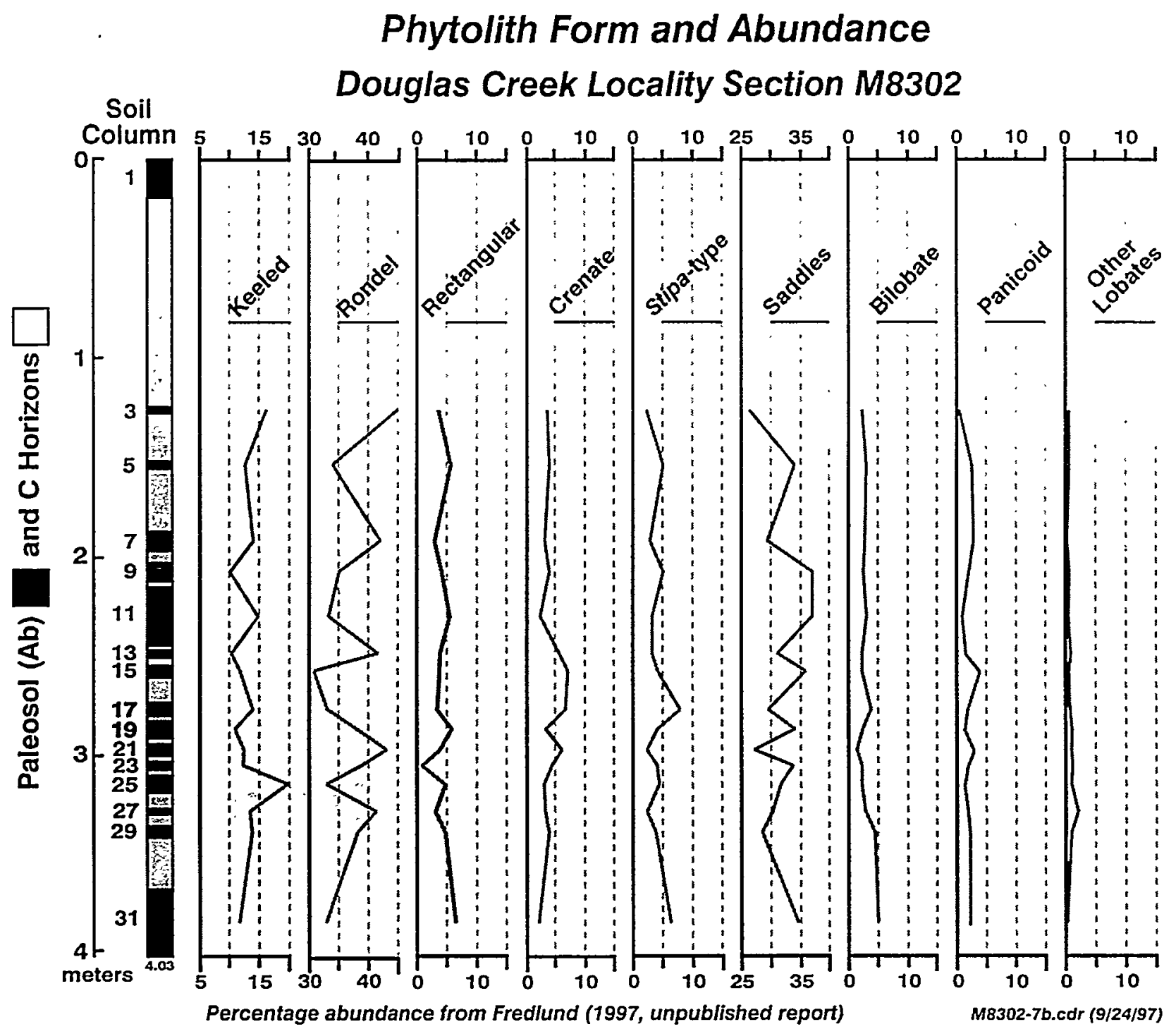

Figure 20. Phytolith form and abundance at Douglas Creek Locality Section M8302. The phytolith percentages illustrated by these curves are from Fredlund (1997, unpublished report) (Table 7). 


\section{Douglas Creek Locality Phytolith Dendrogram}

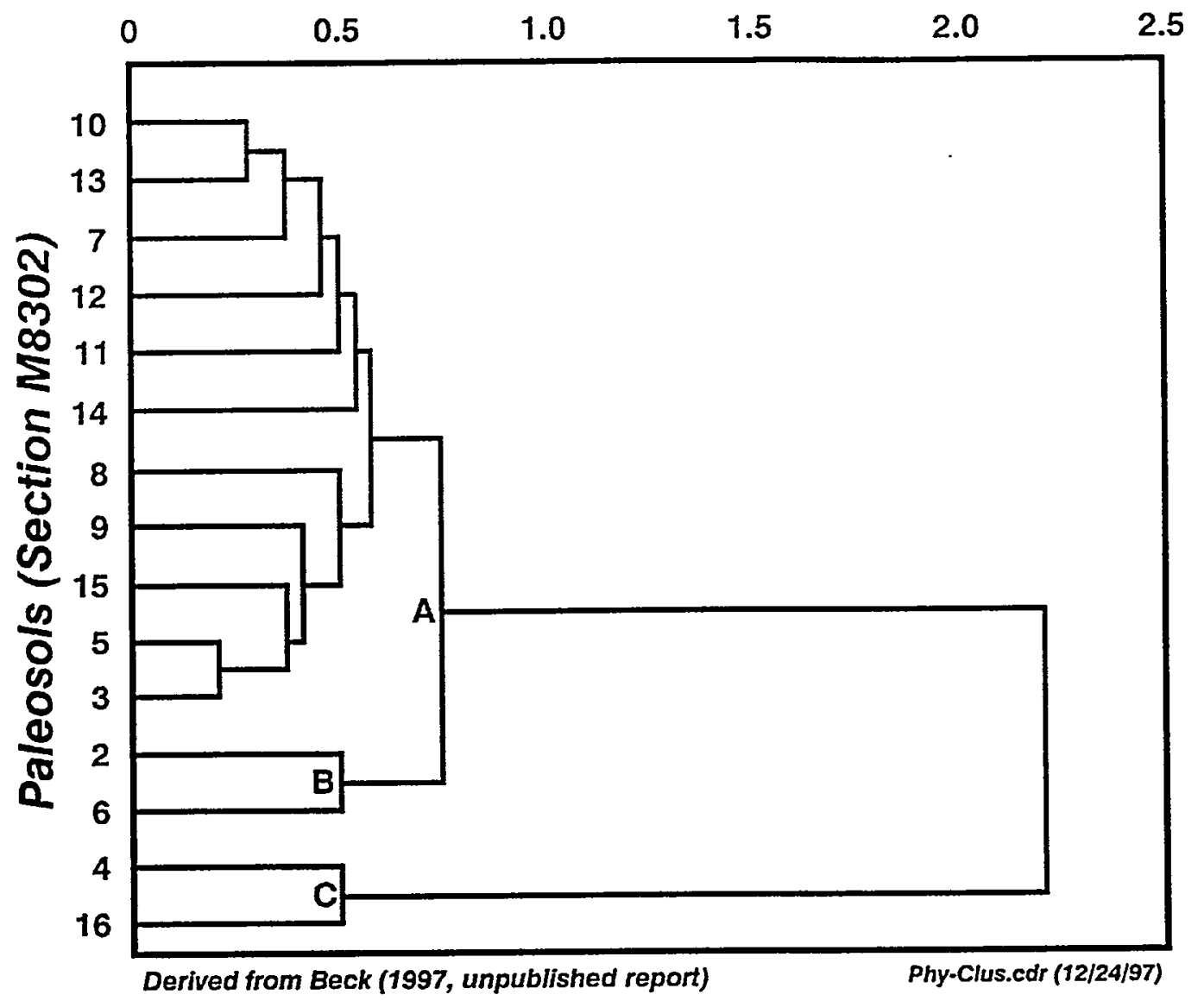

Figure 21. Douglas Creek Locality phytolith dendrogram. This cluster diagram was constructed by Beck (1997, unpublished report) using nonstandardized logratio data, which resulted in a cophenetic coefficient of 0.979 . Three cluster groups, A, B, and C, were identified. 


\section{Project Pulmonate Mollusks}

\section{Knutson Creek Localities}

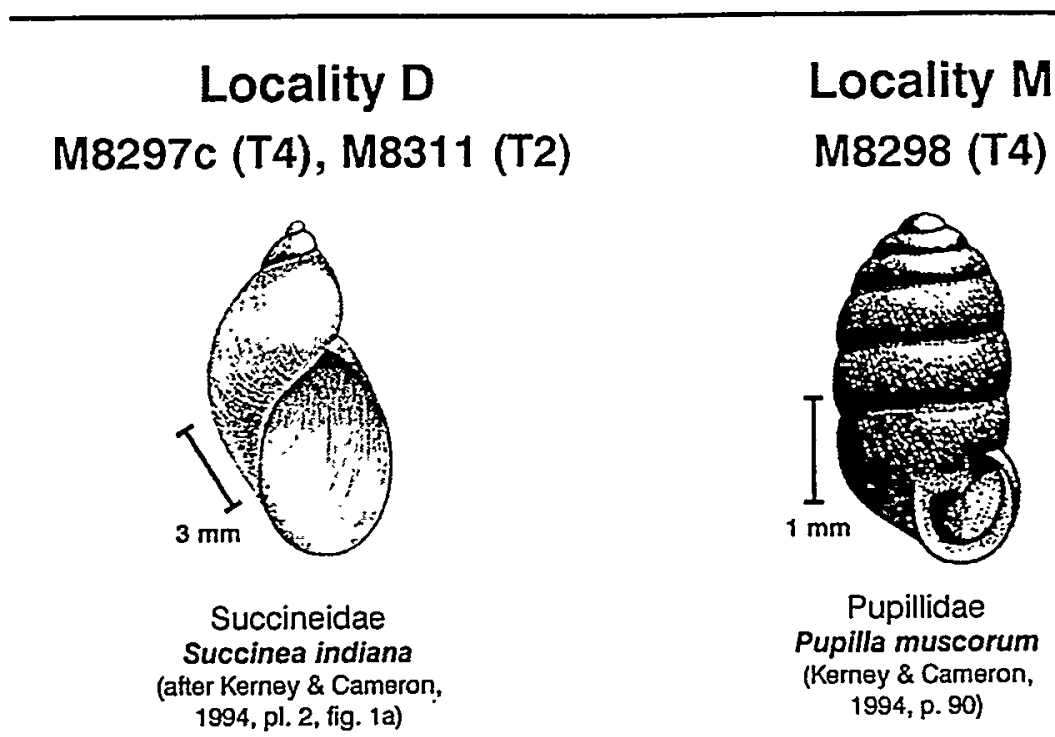

\section{Elbee Bluff Locality}

\section{M18299, a}

(EB-c, $a-b)$

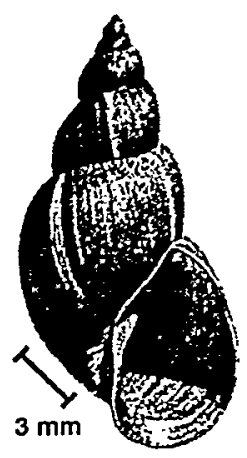

Lymnaeidae Stagnicola elodes (Burch, 1989, fig. 602)
M8299, a (EB-c, b)

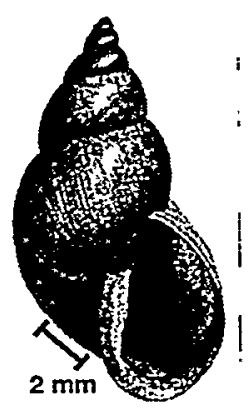

Lymnaeidae Stagnicola caperata (Burch, 1989, fig. 628)
M8299a (EB-b)

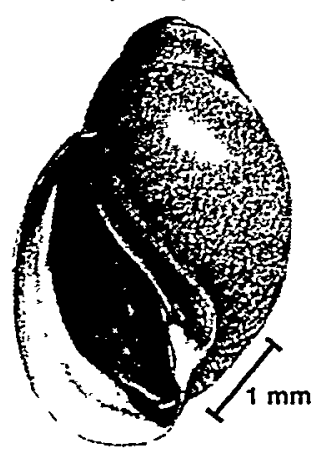

Physidae Physa jennessi (Burch. 1989. fig. 635)
M8299a

(EB-a, b)

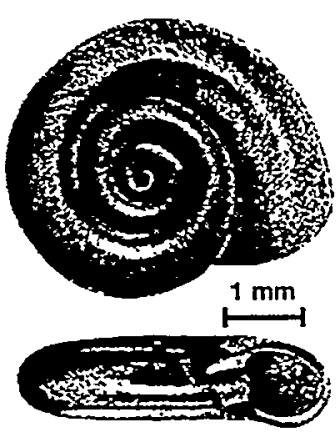

Planorbidae Gyraulus circumstriatus (Burch, 1989, fig. 707[a, b])

Moll-1.cor (10/15/97)

Figure 22. Project pulmonate mollusks. The snails illustrated here are representative of the morphologies and taxa from project localities. 


\section{Douglas Creek Section M8302 \\ Calibration of Paleosols by Year and Thickness}

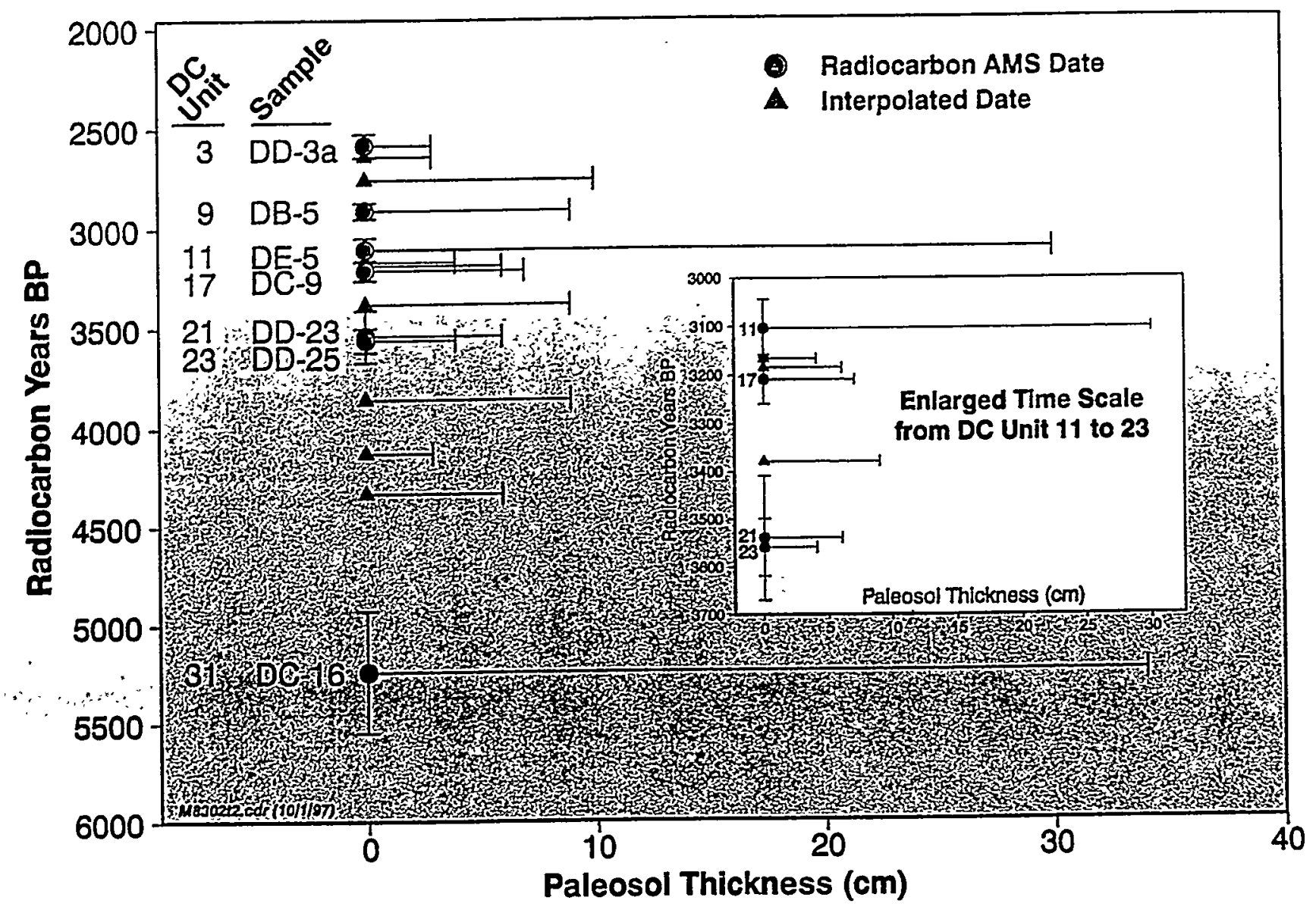

Figure 23. Paleosol radiocarbon dates for Douglas Creek Locality composite Section M8302. This graph illustrates the radiocarbon dates (as dots) and interpolated dates (as triangles) and the relative thickness of paleosols ( $\mathrm{x}$-axis). A subplot provides resolution for the closely spaced paleosols between 3100 and 3600 YBP. 
Time Series Analysis
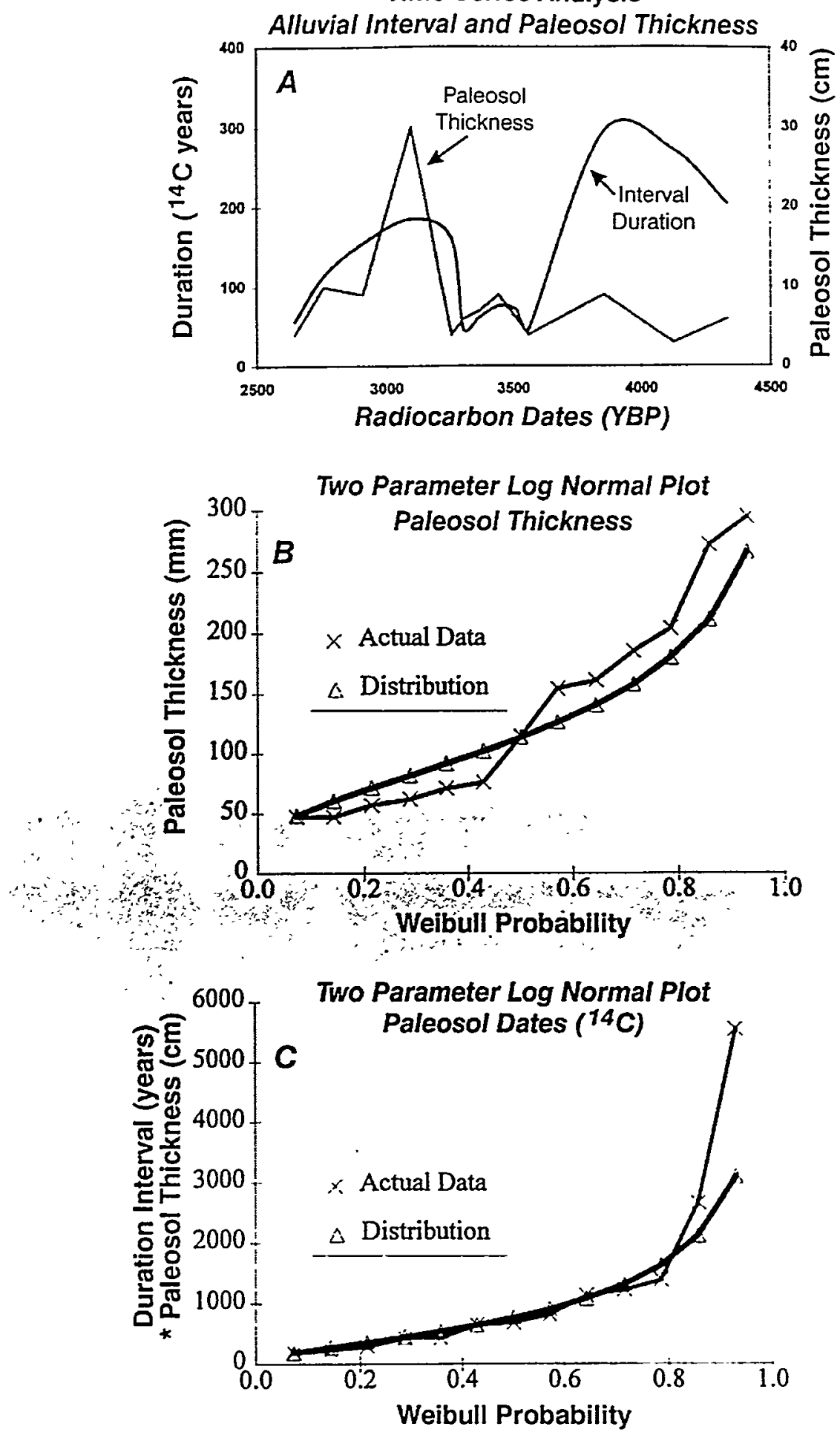

Figure 24a-c. Figure 24a. Time series analysis of radiocarbon dates and paleosol thicknesses. Figure 24b. Lognormal distribution (Weibull probability) of paleosol thicknesses. Figure 24c. Lognormal distribution (Weibull probability) of paleosol radiocarbon dates. 


\section{Paleosol Study Localities}

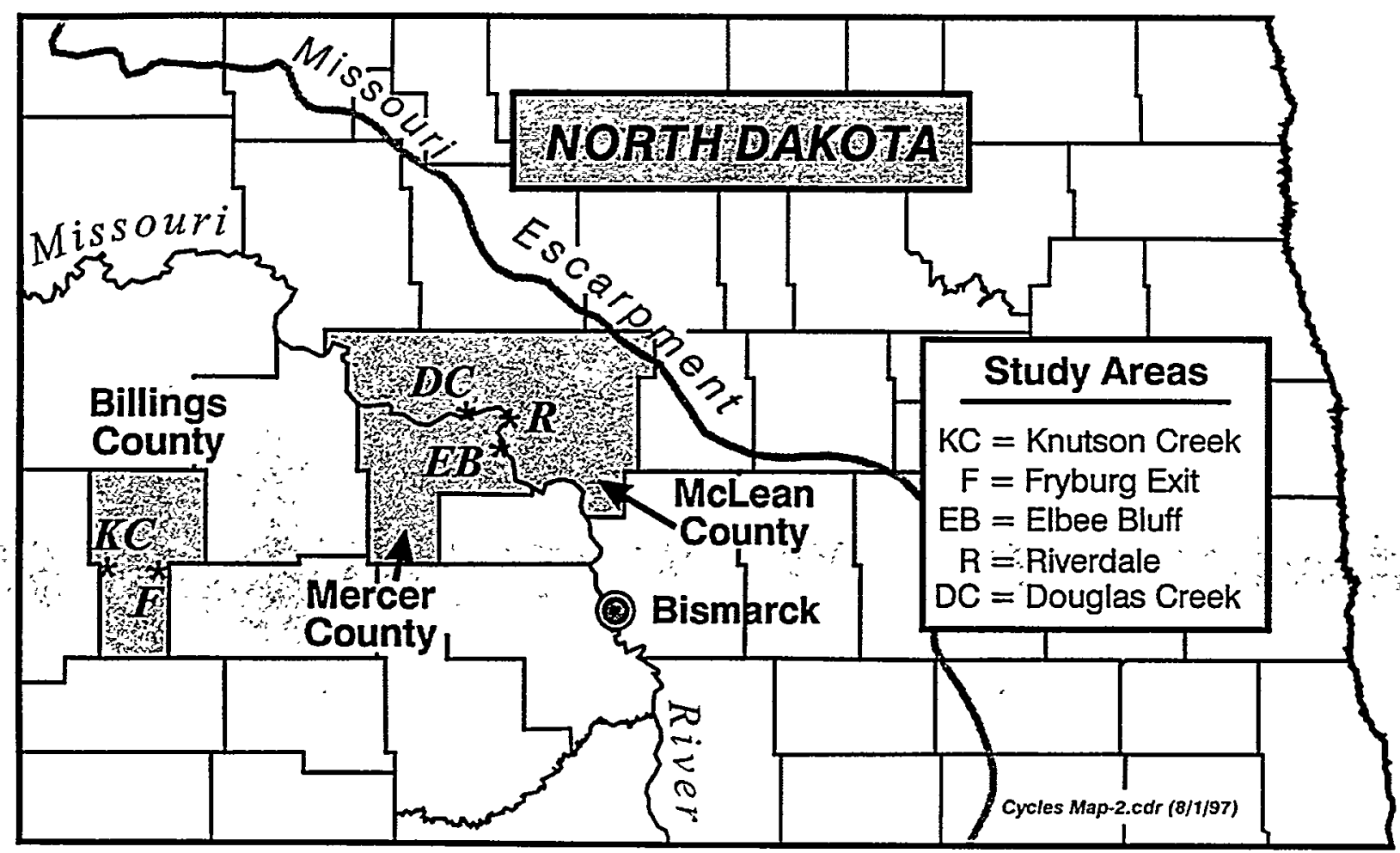

Figure 25. Paleosol study localities in North Dakota. This figure illustrates the occurrence of project localities on a map of North Dakota counties. The eastern edge of drier conditions is represented by the Missouri Escarpment. 


\section{Little Missouri River Badlands Late Quaternary Section}

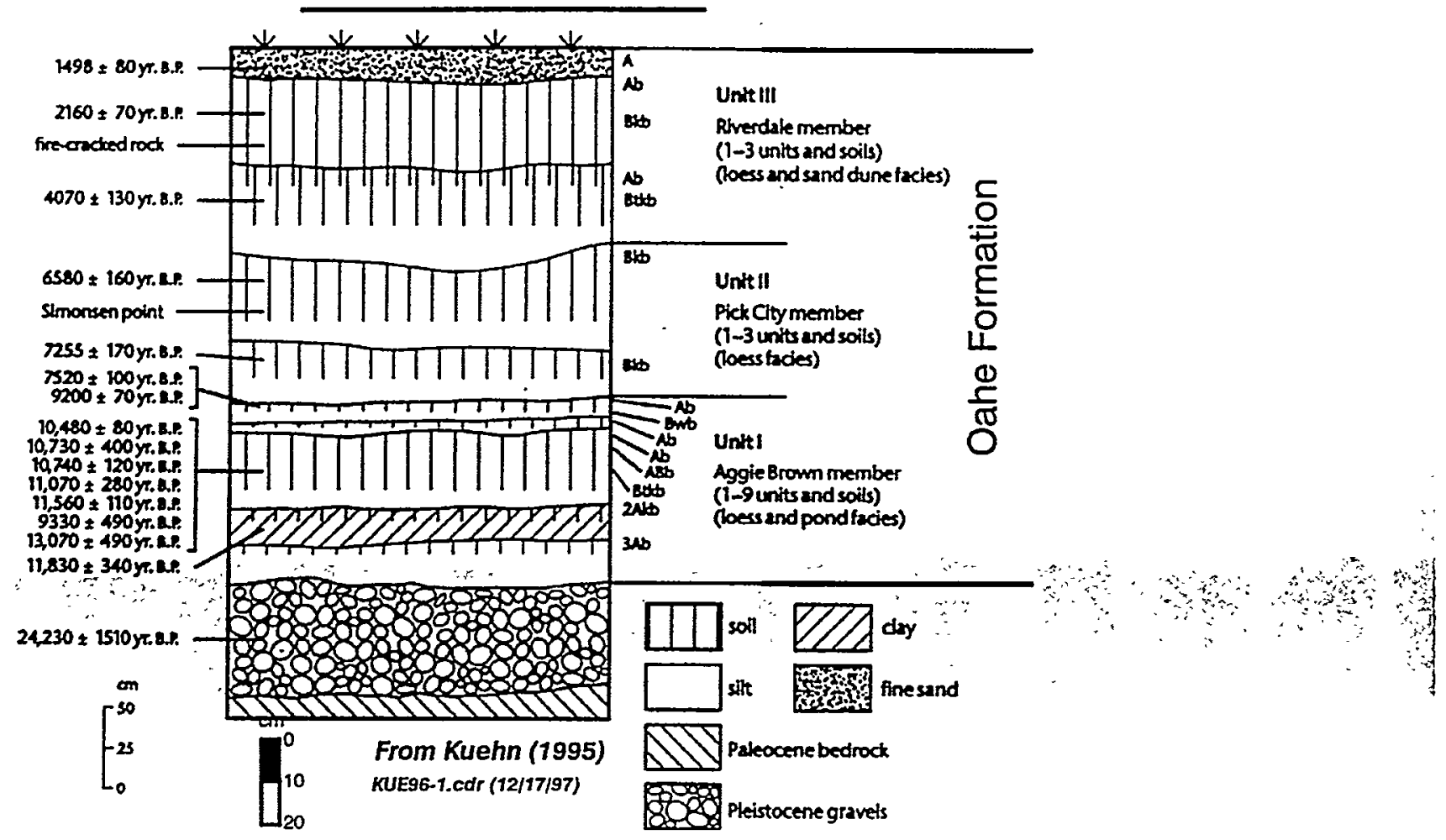

Figure 26. Late Quaternary summary section of the Little Missouri

River badlands. This figure illustrates the litho-stratigraphy and available radiocarbon dates as of Kuehn (1996, fig. 1) in the badlands of the Little Missouri River (compare Figure 91). This record covers the time interval considered in this report. 


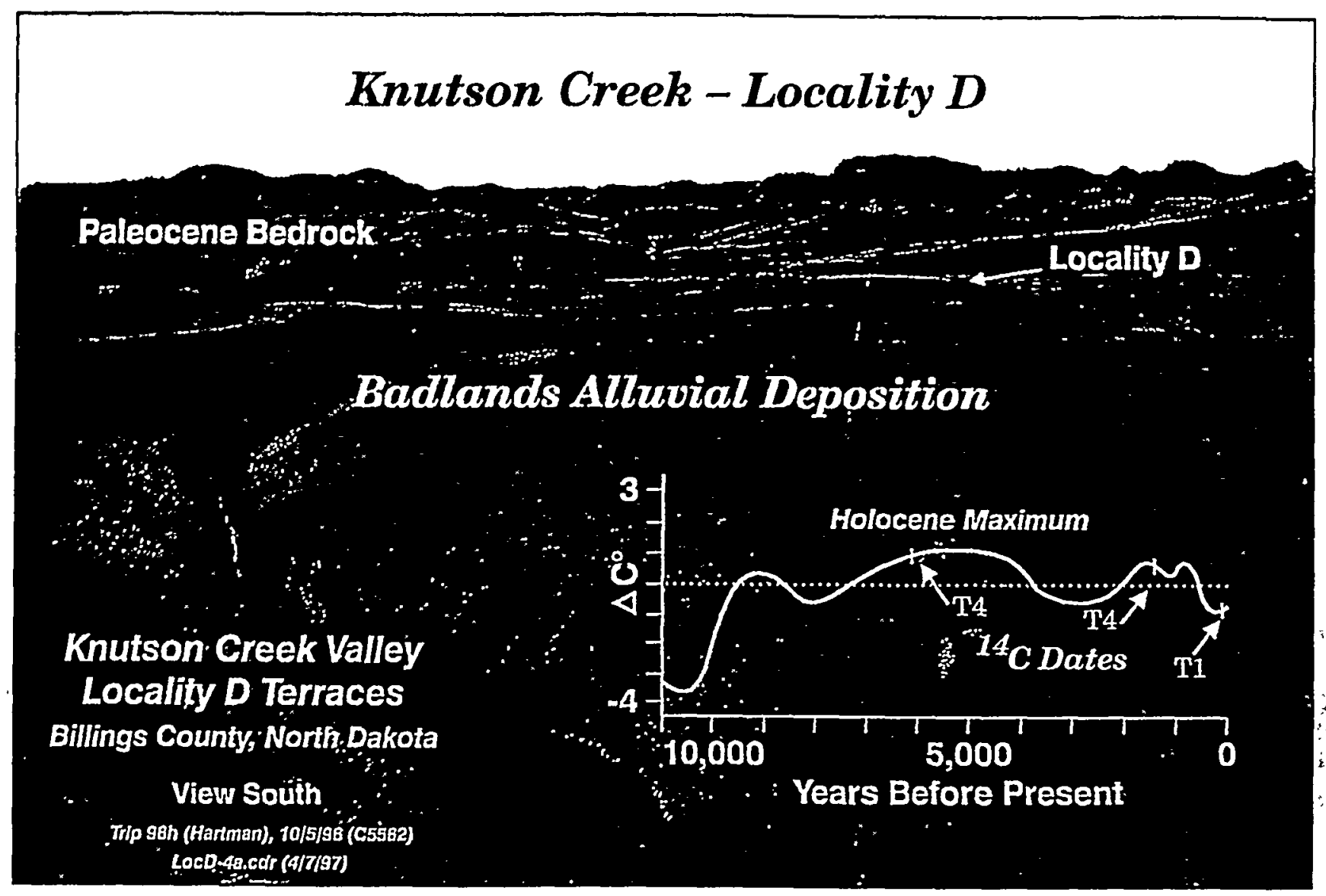

Figure 27. Knutson Creek Locality D, Billings County, North Dakota. View downstream across Knutson Creek, a tributary of the Little Missouri River. The approximate age of Locality $\mathrm{D}$ is illustrated relative to a temperature change curve for the Holocene. The name Locality D is from Kuehn (1995). 


\section{Knutson Creek Localities $D$ and $M$ \\ Medora Quadrangle, Billings County, North Dakota Theodore Roosevelt National Park}

Sec. 4, T. 140 N., R. 102 W.

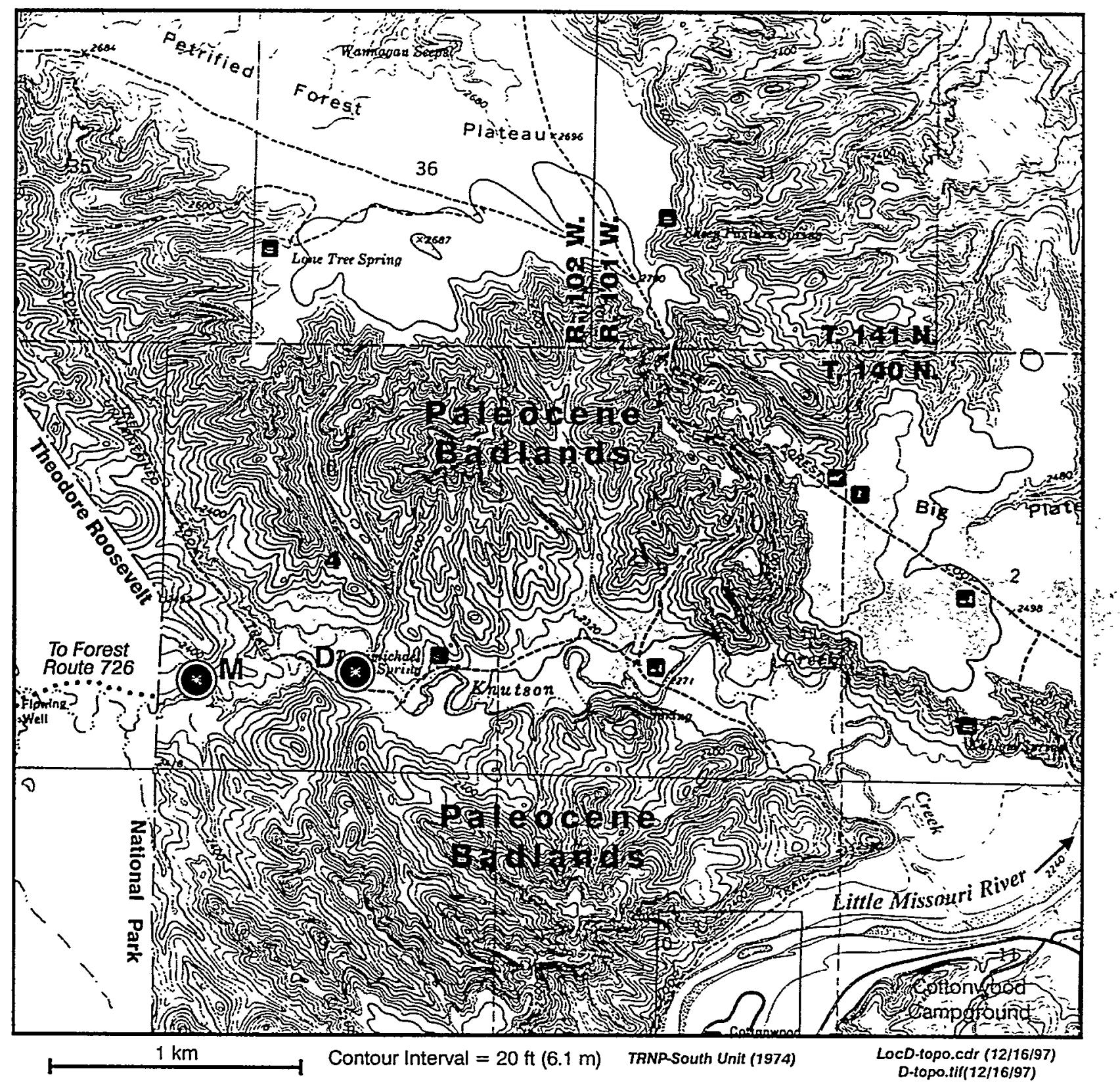

Figure 28. Topographic location map of Knutson Creek Localities D and M (Medora Quadrangle). The numbers inside dashed squares, approximately $1.6 \mathrm{~km}$ on a side (a square mile), are township (T.) and range (R.) sections. 


\section{Knutson Creek Localities $D$ and $M$}


Figure 29. Air photo location map of Knutson Creek Localities D and M. The Knutson Creek localities are located near the west boundary of Theodore Roosevelt National Park in northern Billings County. The bright white and rugged surfaces represent the Paleocene-age badlands bounding the alluvial valley of Knutson Creek. Its confluence with the Little Missouri River is within $1.6 \mathrm{~km}(1 \mathrm{mi})$ of the east edge of this map. 


\section{Locality D Sections and Terraces}



Figure 30. Knutson Creek Locality $D$ sections and terraces. View upstream of cutbank exposures. Badlands of the Paleocene-age Bullion Creek Formation, seen on the horizon, provide one source of alluvial sediments. 


\section{Locality D Sections and Terraces}

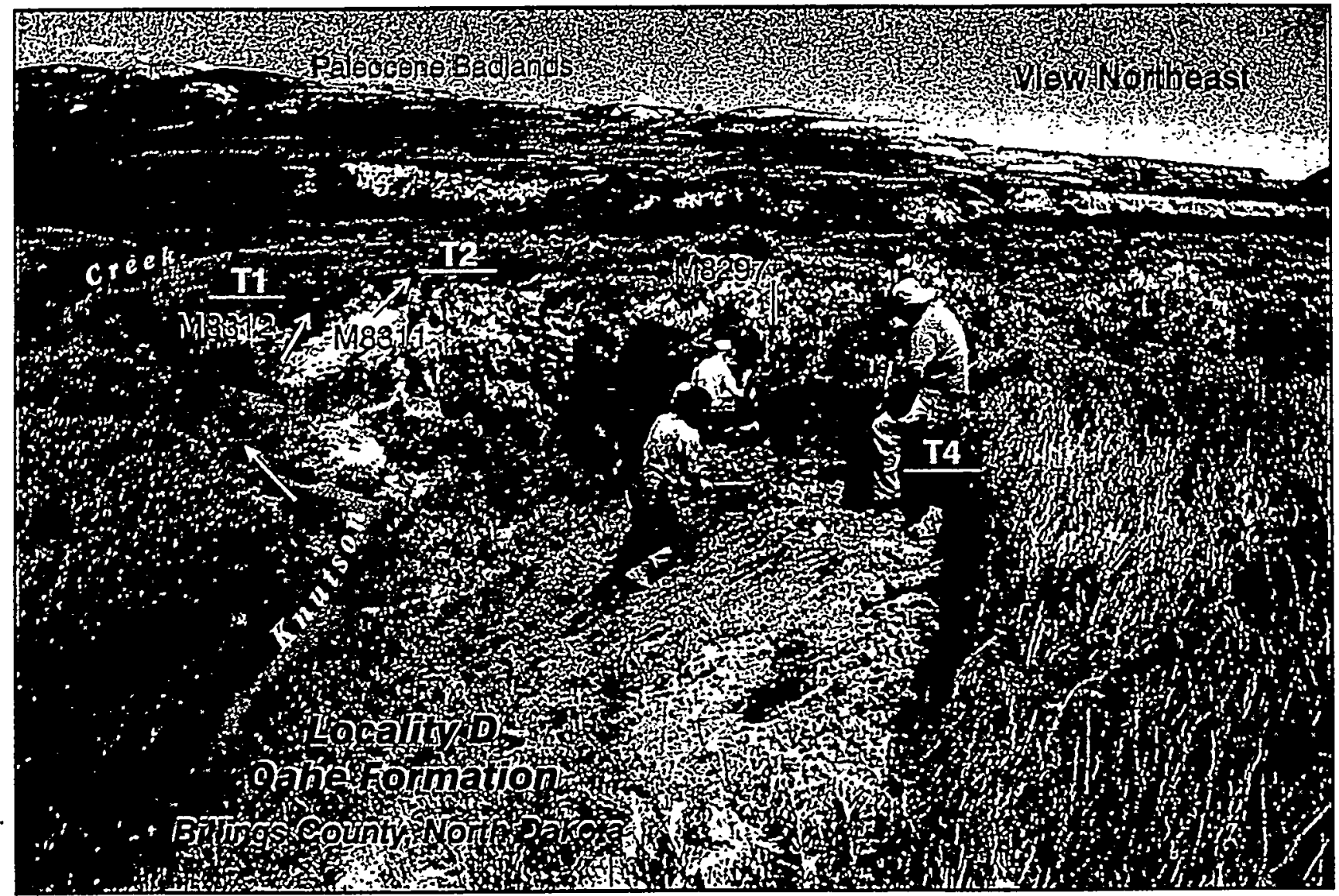

Figure 31. Knutson Creek Locality $D$ sections and terraces. View downstream of worked cutbank exposures. Badlands of the Paleocene-age Bullion Creek and Sentinel Butte Formations are seen to the north and northeast. Terraces 4 to 1 represent successively younger terraces in Theodore Roosevelt National Park. Terrace 2 is not present at Locality D (Kuehn, 1995). 


\section{Locality D, Section M8297, Terrace 4 Oahe Formation}



Figure 32. Section M8297 and sample horizons on Terrace 4. This figure illustrates the lithic units (Units 114 ) recognized in this sequence of paleosols and the sampled horizons (e.g., D-1) in June 1996 (Section M8297). Every unit was later resampled in October of 1996 (Section M8297a). 


\section{Locality D, Section M8297, Terrace 4 Correlation of Section Units}

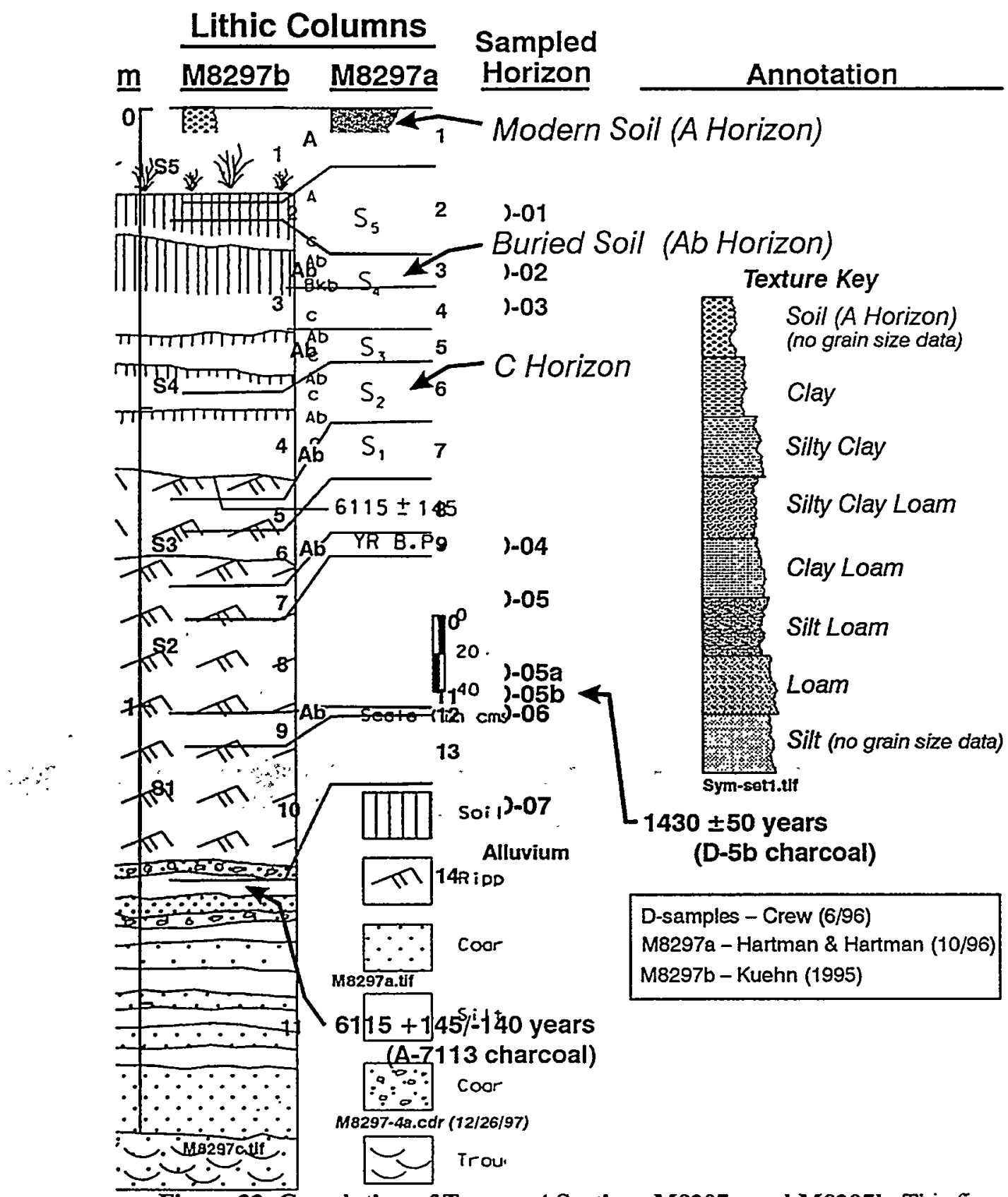

Figure 33. Correlation of Terrace 4 Sections M8297a and M8297b. This figure represents the correlation of lithologies between sections measured by Kuehn (1995; Section M8297b is modified from Kuehn fig. 30) and Hartman and Hartman (10/96, M8297a). This figure includes the sampled horizons and associated radiocarbon dates. Unit 11 (Kuehn, 1995; S1) is a medium-thick bed of massive silt, topped by a weakly developed soil (Entisol). A charcoal sample from near the top of the unit yielded a radiocarbon date. The S-numbers of Section M8297b are soil sequence numbers from Kuehn (1995), representing the basic alternation of Ab-and C-horizon couplets. 


\section{Texture Nomenclature for Sections M8297 and M8297a}

\section{Section M8297 Texture}

100

80
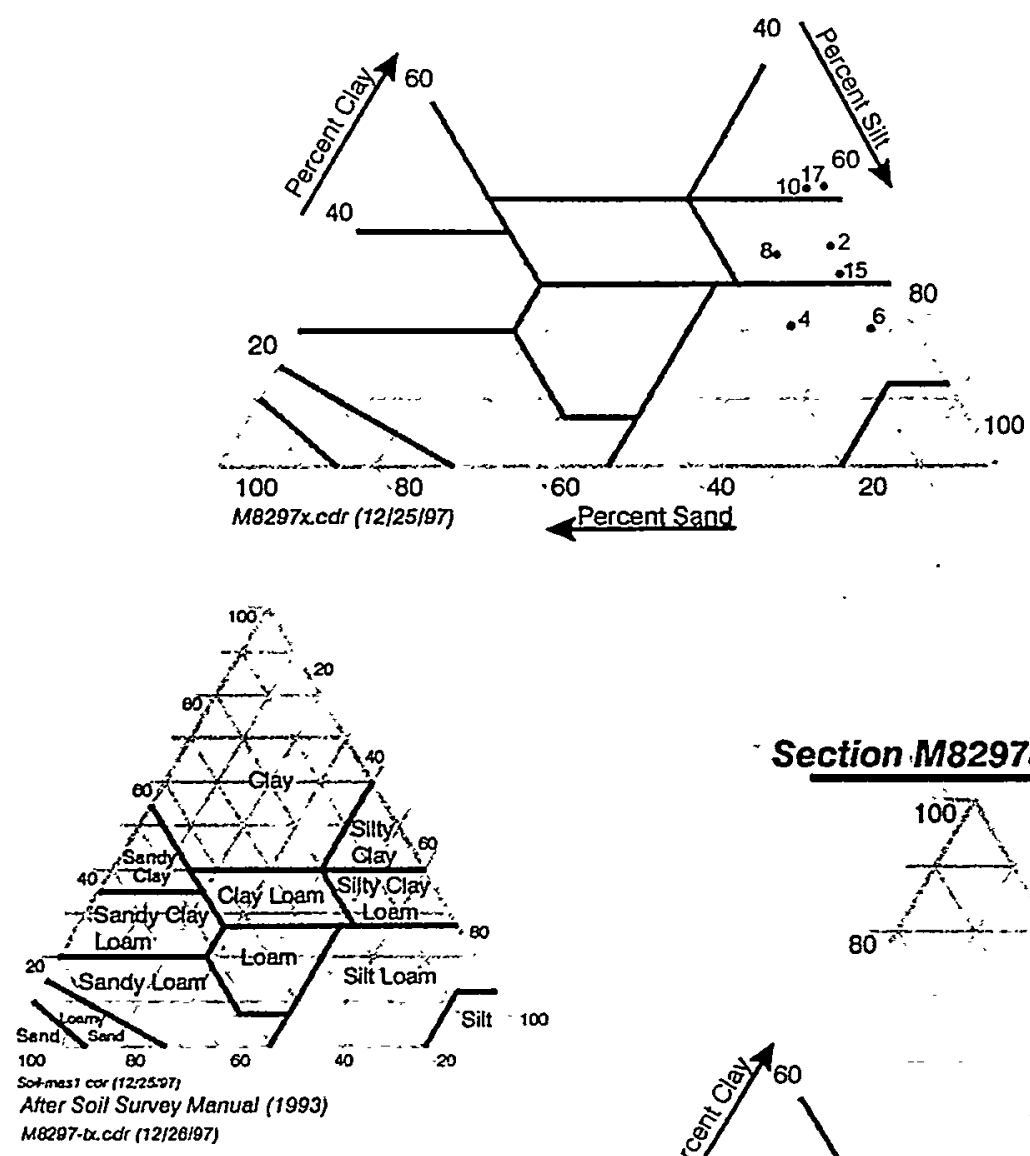

\section{Section M8297a Texture}
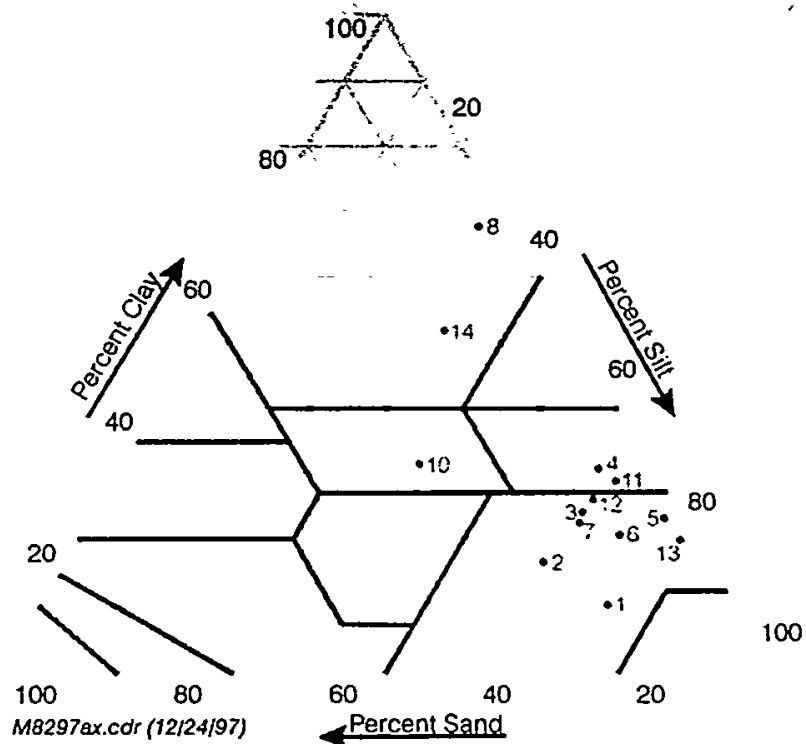

Figure 34. Texture analysis and nomenclature of Sections M8297 and M8297a. Each sediment sample is plotted by unit number onto a diagram of texture nomenclature. Most samples are modified loams, representing a high level of silt, some clay, and less sand. 


\section{Locality D, Section M8297, Terrace 4 \\ Stable Carbon Data $-\delta^{13} \mathrm{C}$}

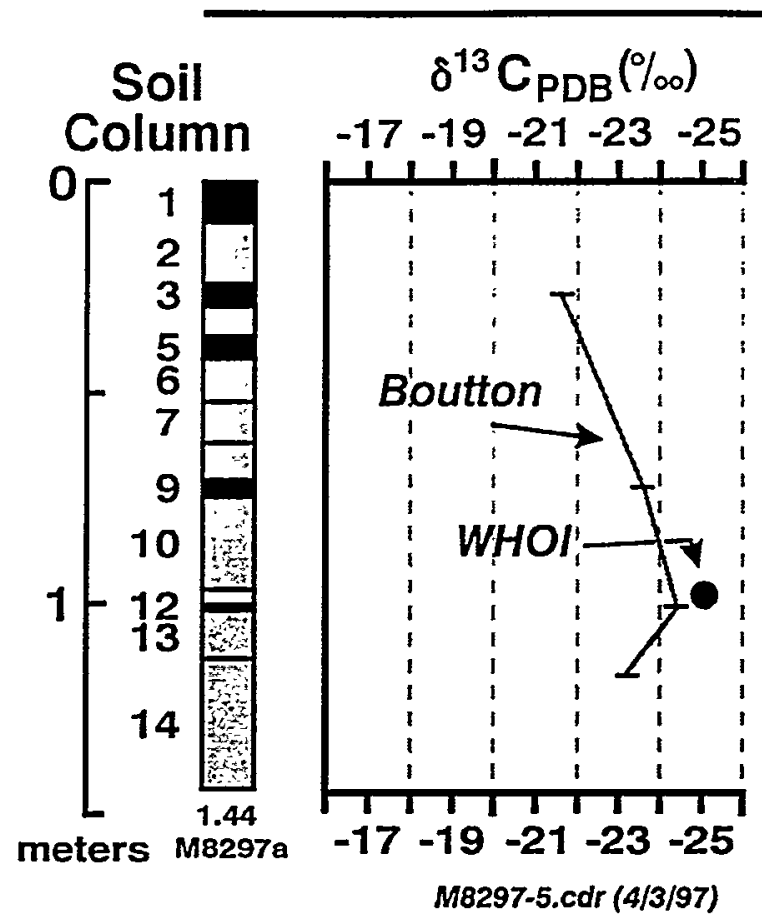

Paleosol

Column

Horizon

D-01 Modern Soil (A horizon)

D-02 $-03-21.62$ (ND17 - bulk)

D-04 $\longleftarrow-23.63(N D 18-b u l k)$

D-05b $\longleftarrow-25.07$ (D-5b-charcoal)

D-06 $\longleftarrow-24.43$ (ND19-bulk)

D-07 $\longleftarrow-23.20$ (ND20-bulk)

$\frac{\delta^{13} C_{\text {PDB }}(\%)}{\text { Boutton - bulk samples }}$
WHOI - charcoal samples

\section{Paleosol (Ab)}
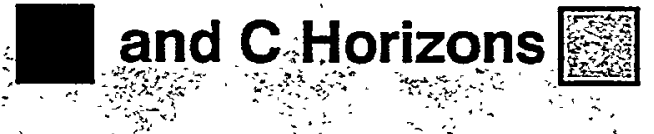

Figure 35. Stable carbon data for Locality D on Terrace 4. Stable carbon values were derived from laboratory analyses by Boutton (written communication, 1996) and by WHOI (written communication, 1996, 1997). The values between these two groups of analyses are not directly comparable, as different processes and fractionation procedures were employed. Boutton's analyses used bulk samples specifically for stable carbon interpretation, whereas the WHOI sample was analyzed on a small charcoal sample to derive a radiocarbon date. 


\section{Locality D, Section M8311, Terrace 2 Oahe Formation}

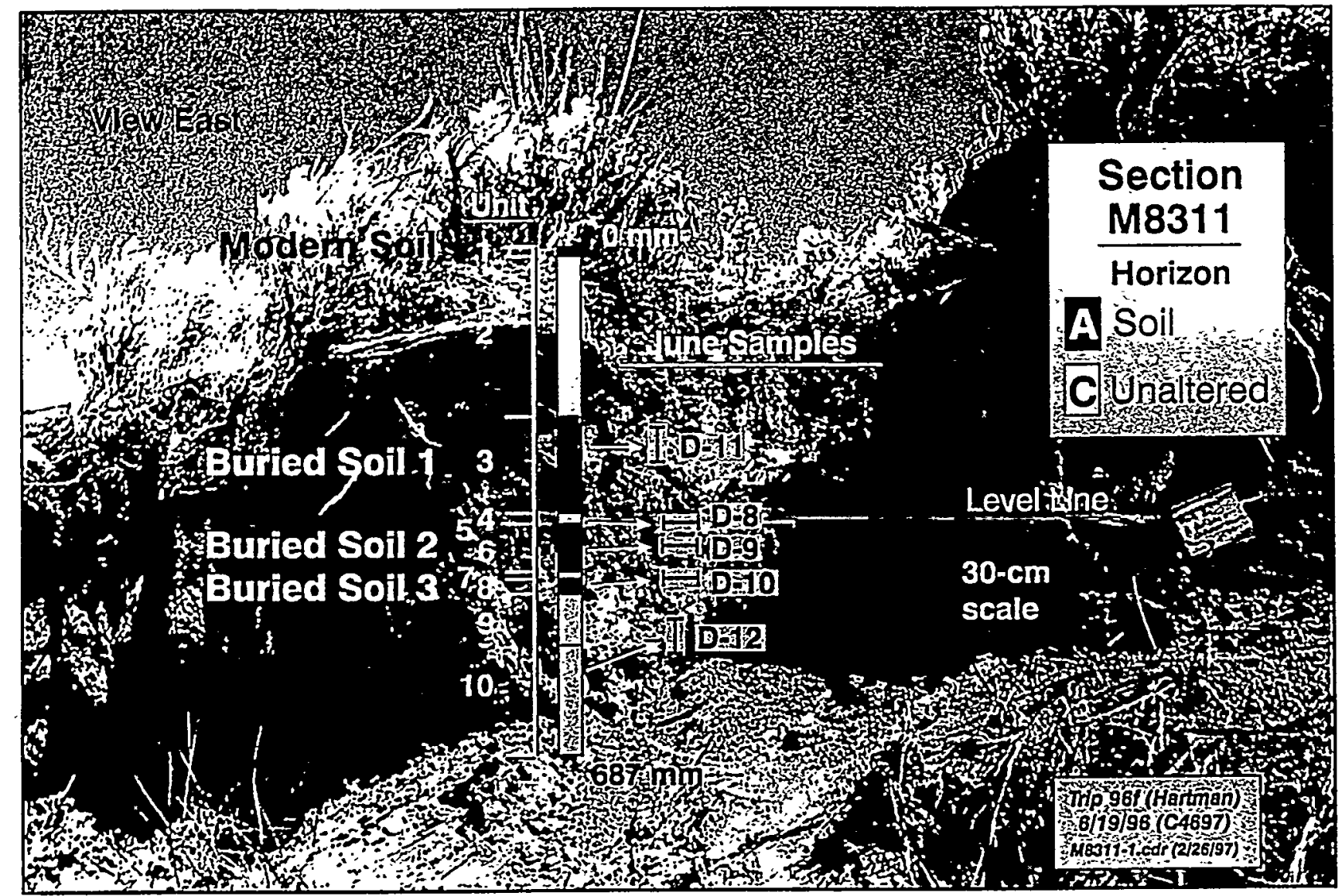

Figure 36. Section M8311 and sample horizons at Locality D on Terrace 2. This figure illustrates the lithic units (Units 1-10) recognized in this sequence of paleosols and the sampled horizons in June 1996 (Section M8311). 


\section{Texture Nomenclature for Section M8311}

\section{Section M8311Texture}

100
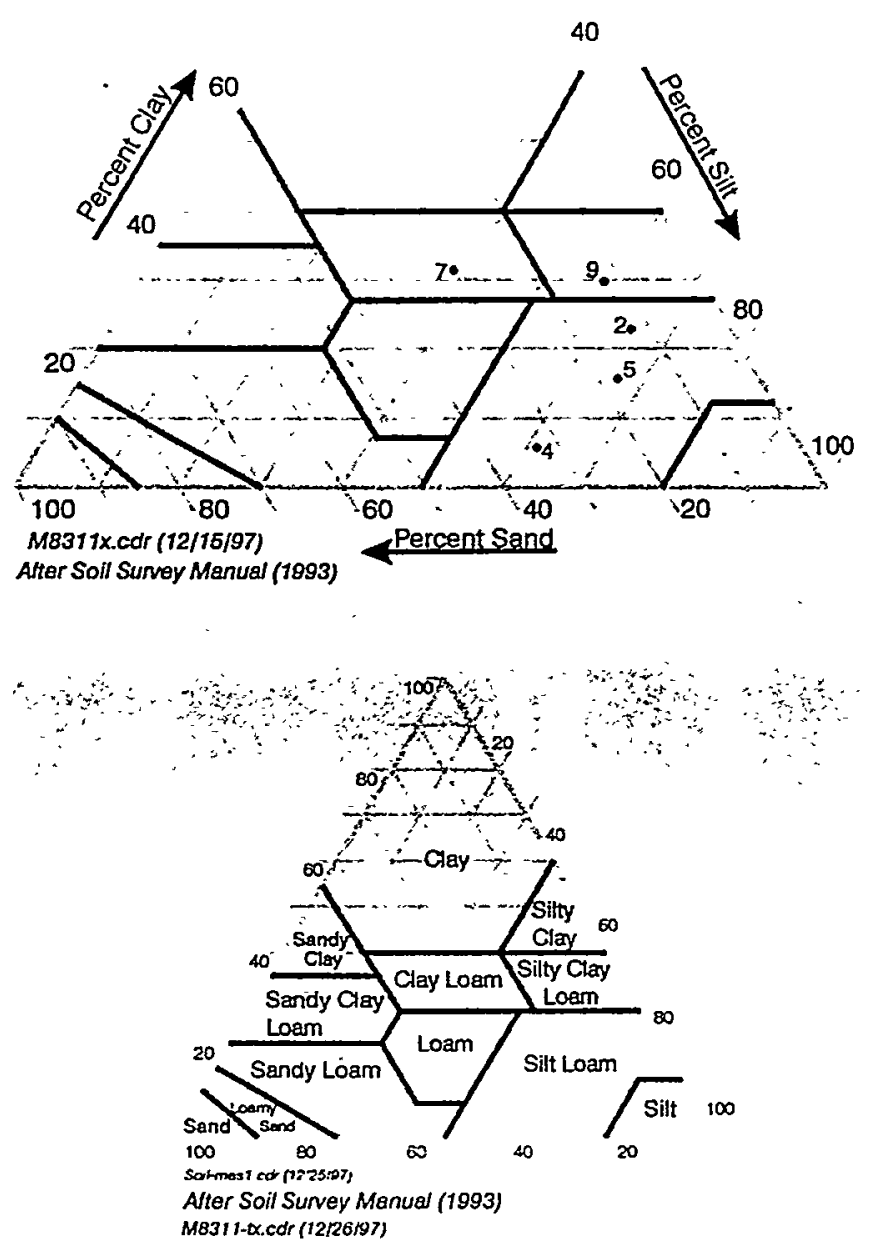

Figure 37. Texture analysis and nomenclature of Section M8311. All sediment samples are plotted by unit number onto a diagram of texture nomenclature. Most samples are modified loams, representing a high level of silt, with some clay and sand. 


\section{Locality D, Section M8311, Terrace 2 Stable Carbon Data $-\delta^{13} \mathrm{C}$}

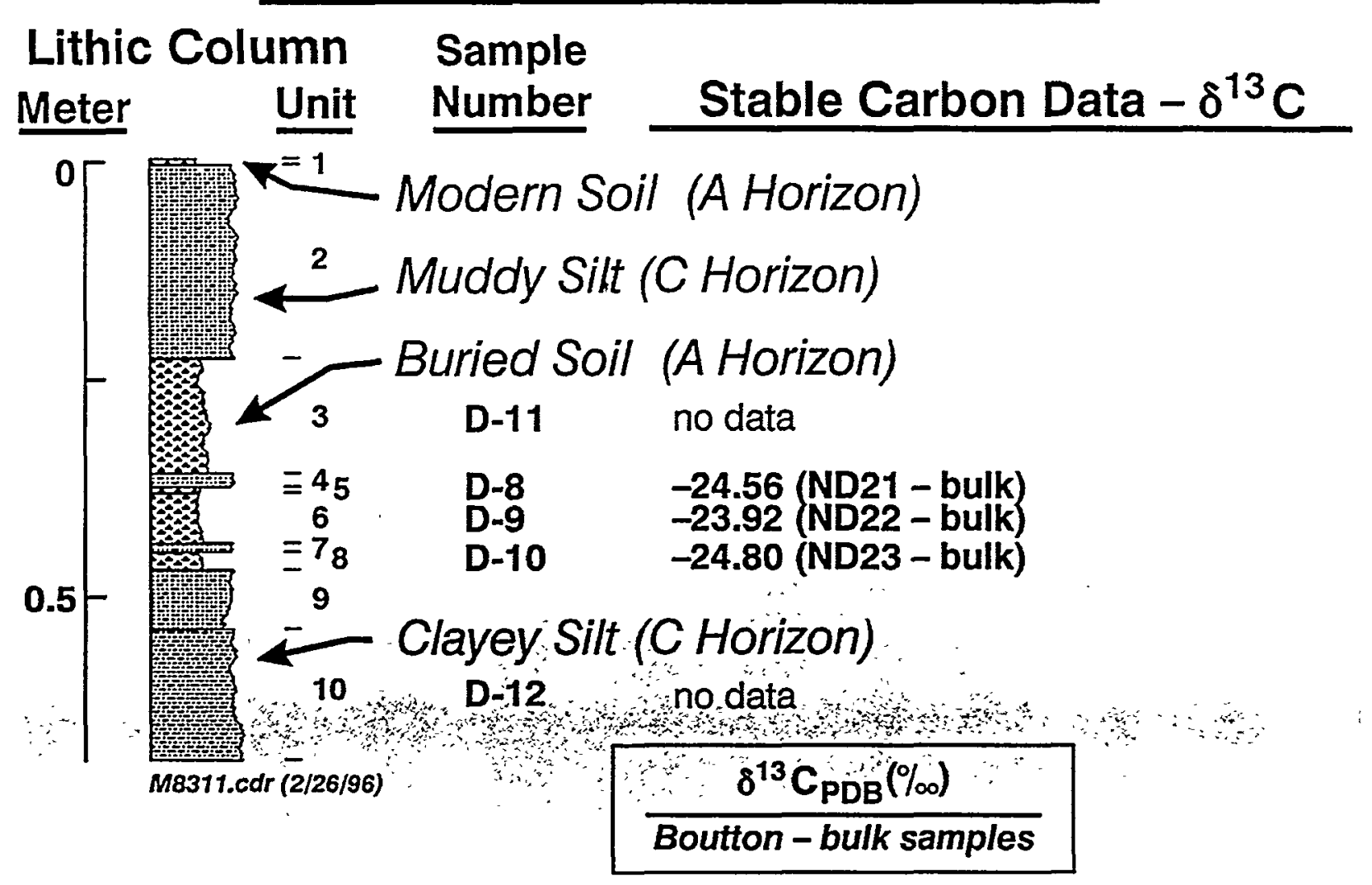

Figure 38. Stable carbon data of Section M8311 on Terrace 2 at Locality $\mathbf{D}$. Stable carbon values were derived from laboratory analyses by Boutton (written communication, 1996). 


\section{Locality D, Section M8312, Terrace 1}

\section{Oahe Formation}

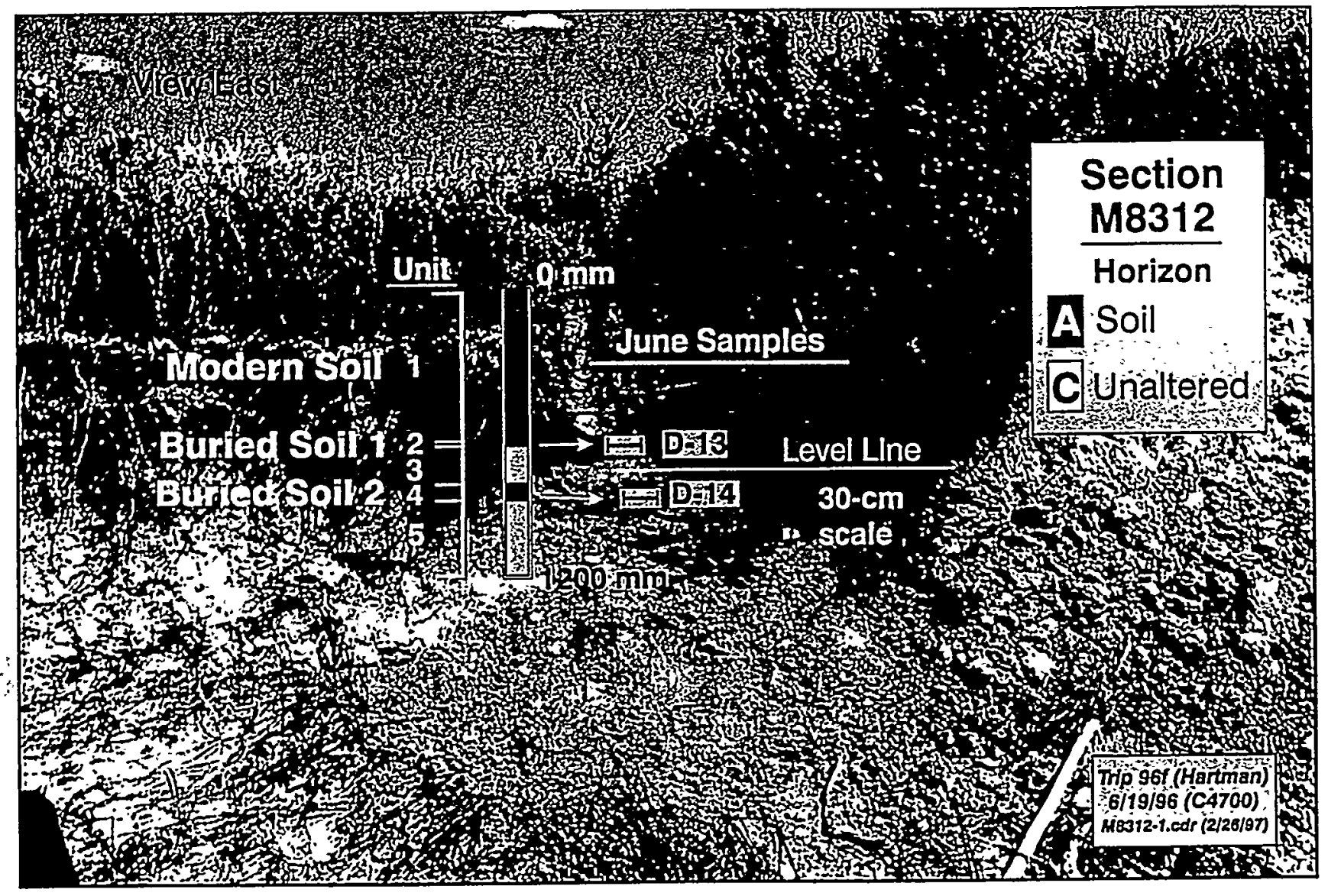

Figure 39. Section M8312 and sample horizons on Terrace 1. This figure illustrates the lithic units (Units 1-5) recognized in this sequence of paleosols and the horizons sampled in June 1996 (Section M8312). 


\section{Texture Nomenclature for Section $M 8312$}

\section{Section M8312 Texture}

100

80
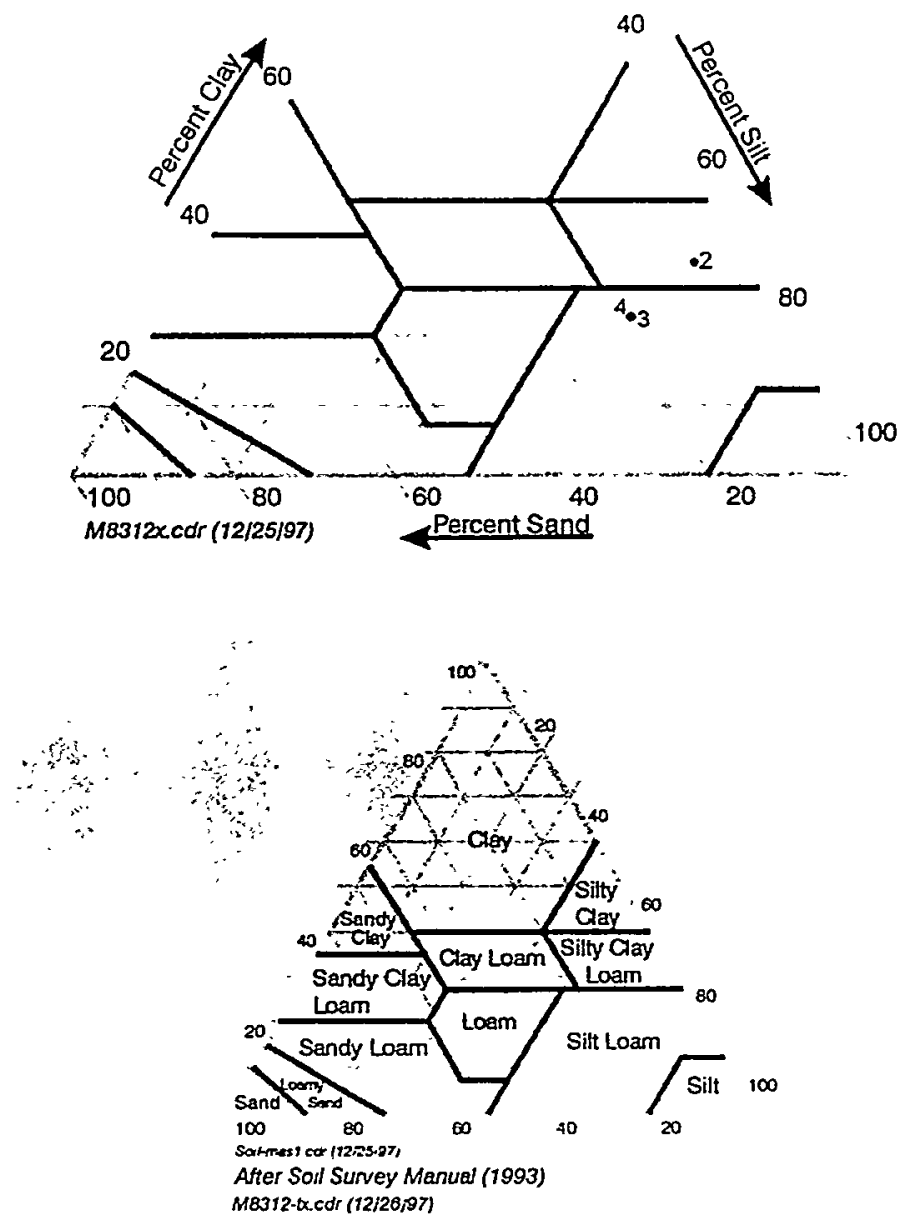

Figure 40. Texture analysis and nomenclature of Section M8312 on Terrace 1. Each sediment sample is plotted by unit number onto a diagram of texture nomenclature. The two samples are modified loams, representing a high level of silt, with some clay and less sand. 


\section{Locality D, Section M8312, Terrace 1 Radiocarbon Data}

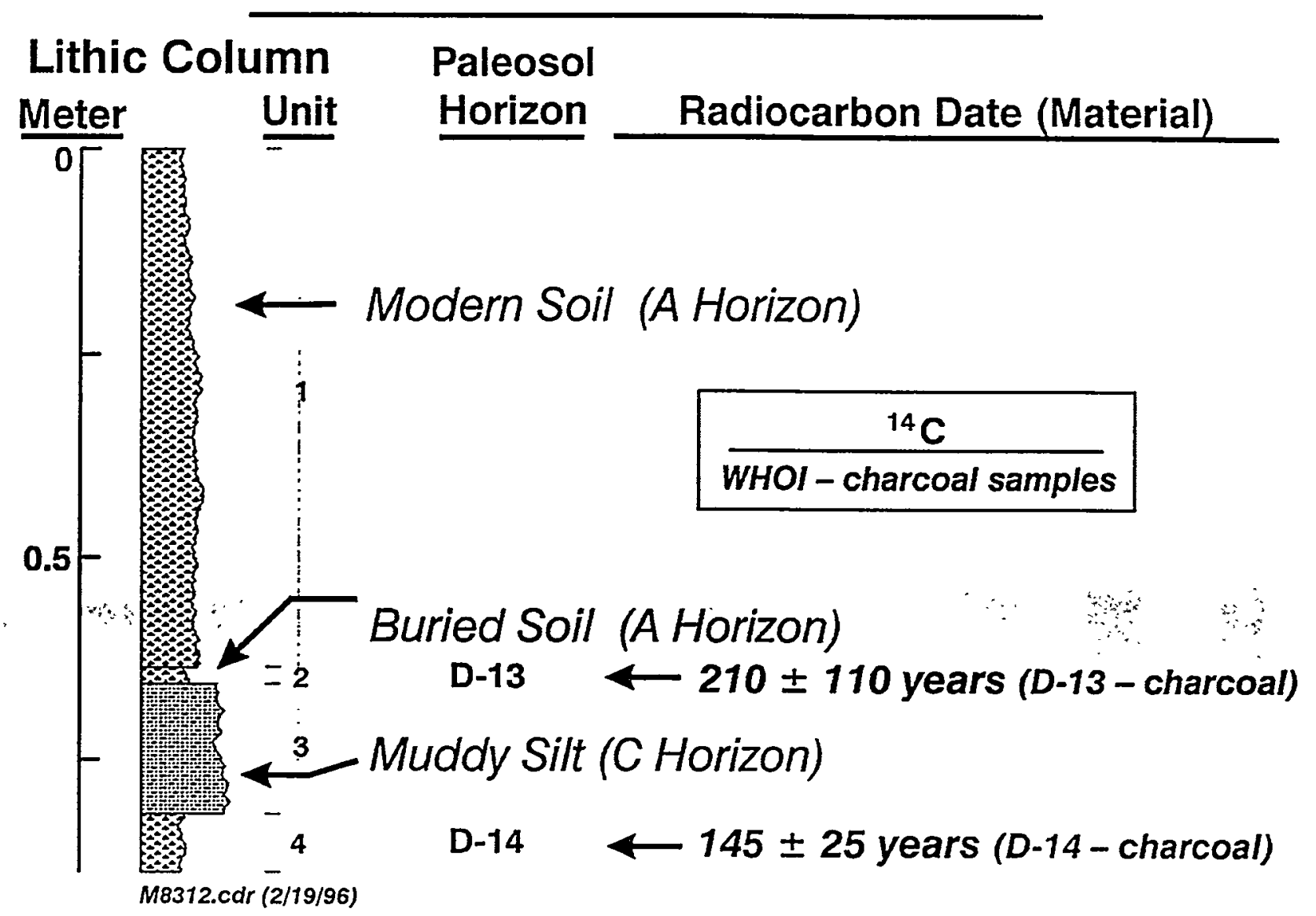

Figure 41. Radiocarbon data of Section M8312 on Terrace 1 at Locality D. Radiocarbon values were derived from laboratory analyses by WHOI (written communication, 1997). The apparently poor date for Sample D-13 is likely due to the very small charcoal sample analyzed, allowing for few iterations. 


\section{Locality D, Section M8312, Terrace 1 Stable Carbon Data $-\delta^{13} \mathrm{C}$}

\section{Lithic Column Paleosol}

$\frac{\text { Meter }}{0[}$ Unit Horizon Stable Carbon Data $-\delta^{13} \mathrm{C}$

$\longleftarrow$ Modern Soil (A Horizon)

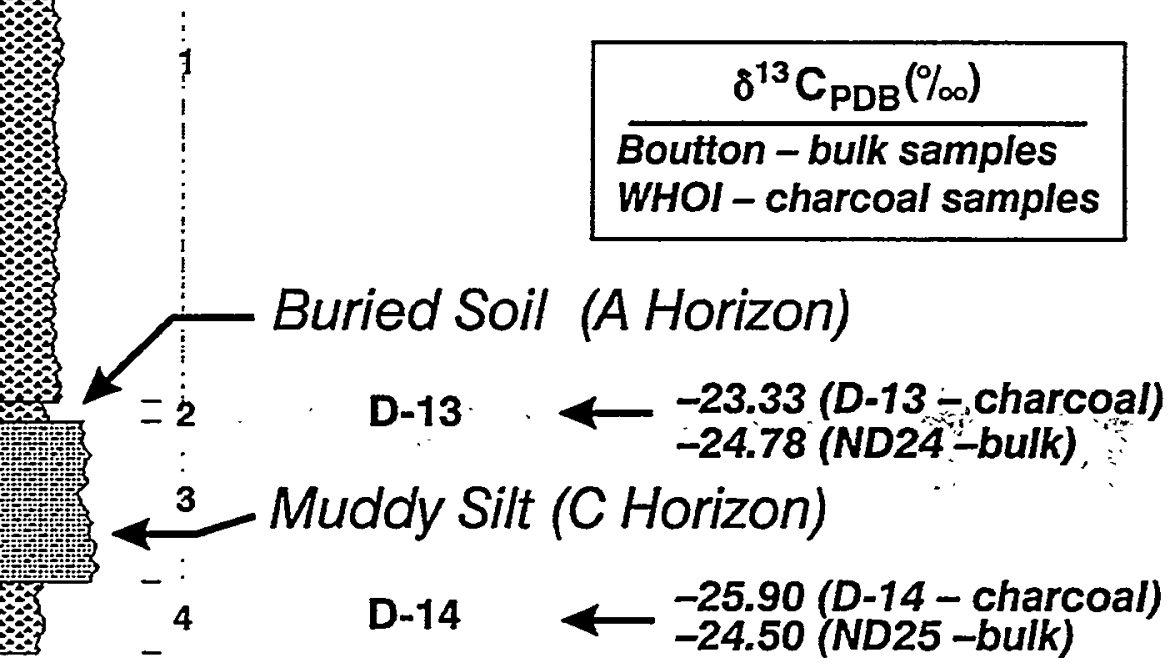

M8312-2.cdr (12/28/97)

Figure 42. Stable carbon data of Section M8312 on Terrace 1 at Locality $\mathbf{D}$. Radiocarbon values were derived from laboratory analyses by Boutton and WHOI (written communications, 1996 and 1997, respectively). 


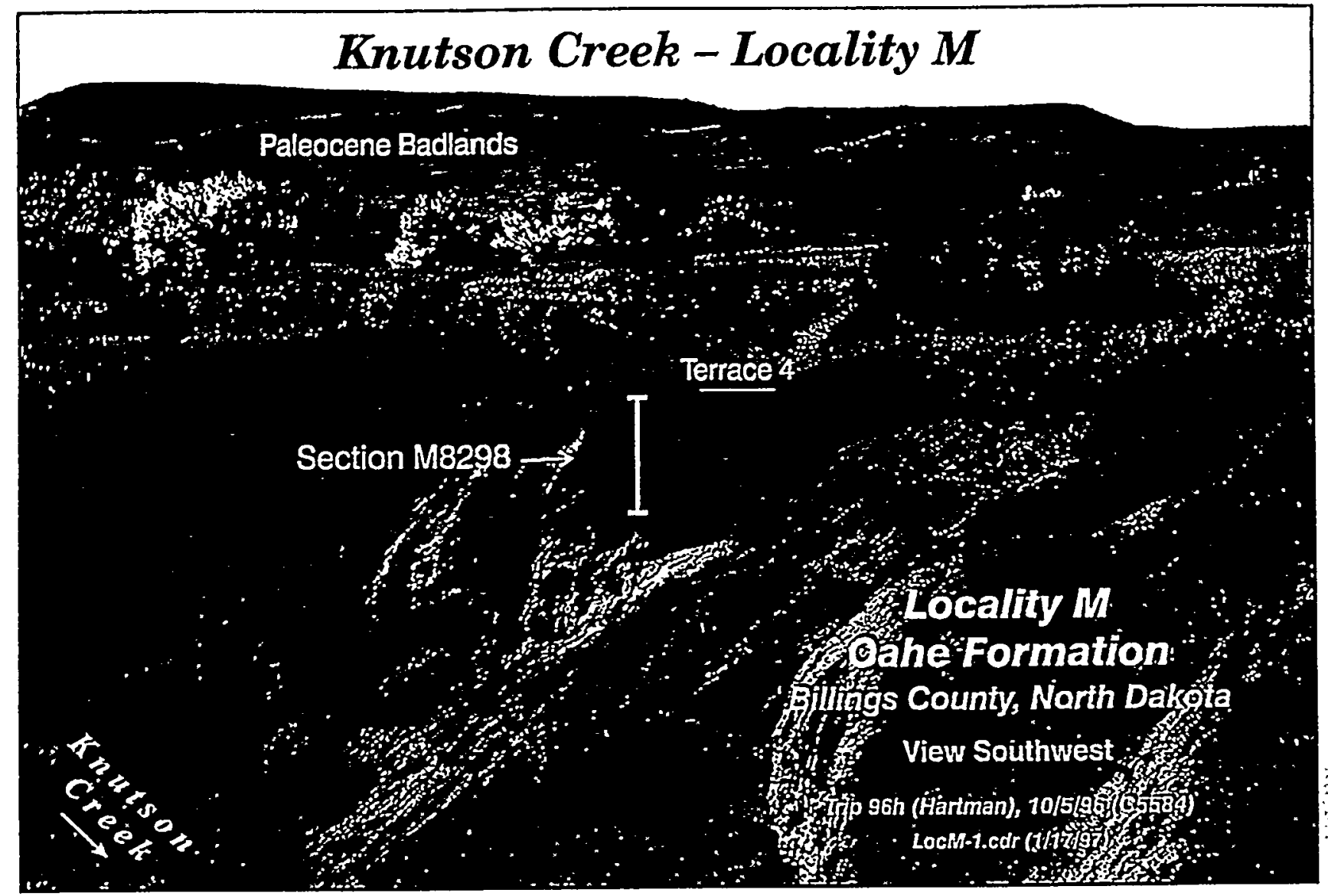

Figure 43. The Knutson Creek Locality M Section and terrace. View upstream of high cutbank exposures. Badlands of the Paleocene-age Bullion Creek and Sentinel Butte Formations, seen on the horizon, provide one source of alluvial sediments. The name Locality M is from Kuehn (1995). 


\section{Locality M, Section M8298, Terrace 4 Oahe Formation}

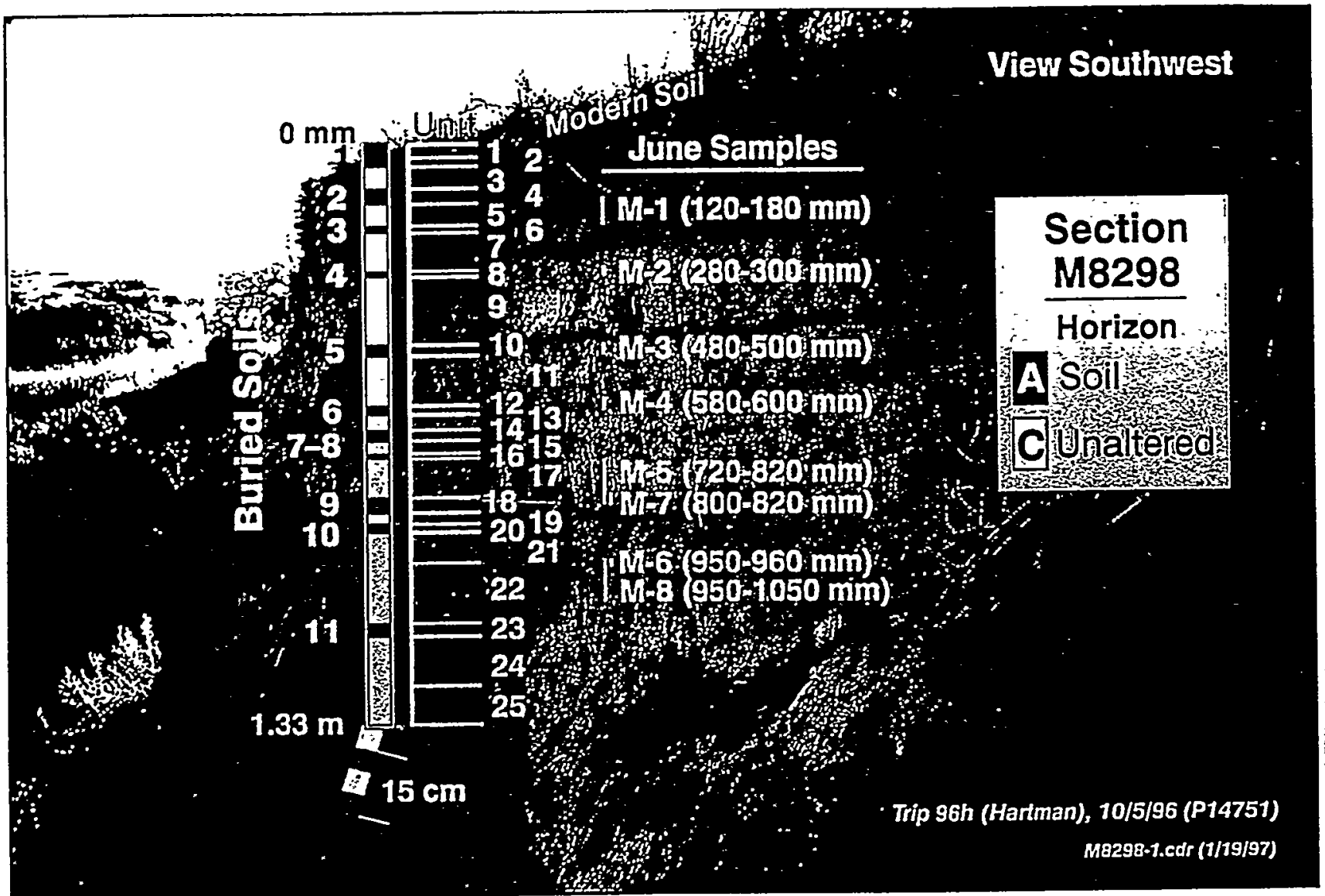

Figure 44. Section M8298 and sample horizons at Locality $M$ on Terrace 4. This figure illustrates the lithic units (Units 1-25) recognized in this sequence of paleosols and the sampled horizons (e.g., M-1) in June 1996 (Section M8298). Every unit was later resampled in October of 1996 (Section M8298a). 


\section{Locality M, Section M8298, Terrace 4 Correlation of Section Units}

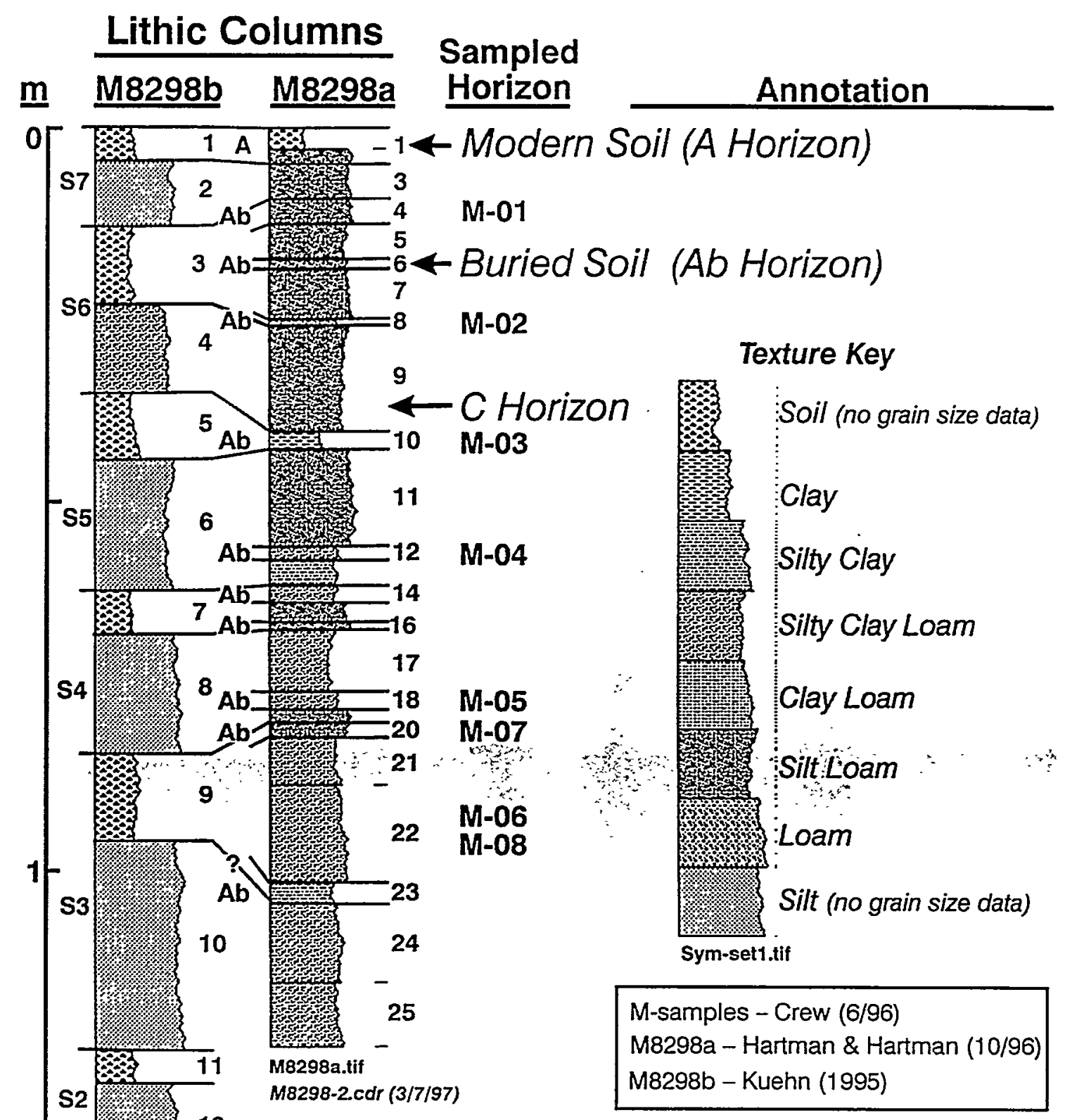

Figure 45. Correlation of Terrace 4 Sections M8298a and M8298b. This figure represents the correlation of lithologies between sections measured by Kuehn (1995; Section M8298b is modified from Kuehn (fig. 32) and Hartman and Hartman (10/96, M8298a). This figure includes the sampled horizons. Insufficient carbon was found to derive radiocarbon dates. The S-numbers of Section M8298b are soil sequence numbers from Kuehn (1995), representing the basic alternation of $\mathrm{Ab}$ - and Chorizon couplets. 


\section{Texture Nomenclature for Sections M8298 and M8298a}

\section{Section M8298 Texture}

100

20

80
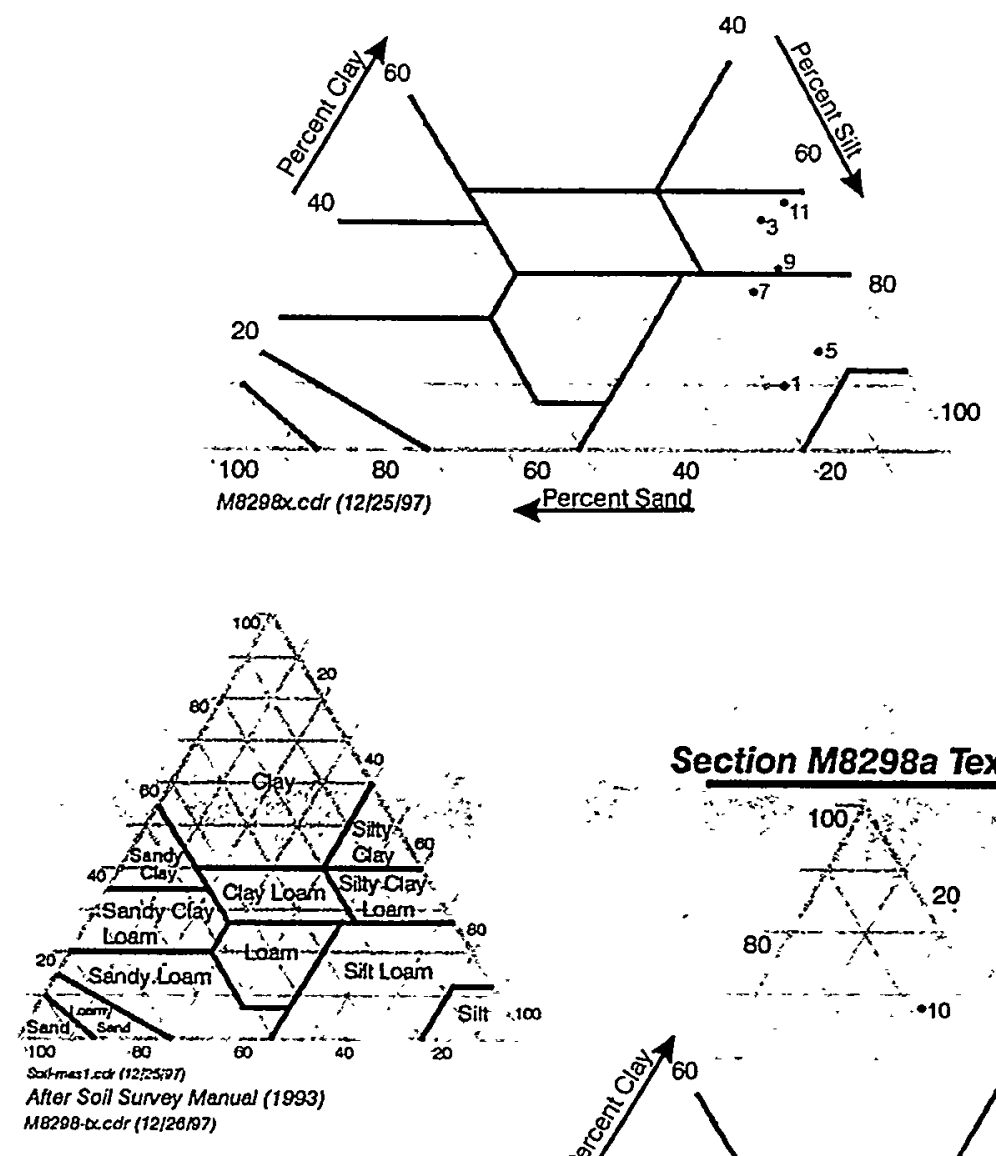

\section{Section M8298a Texture}
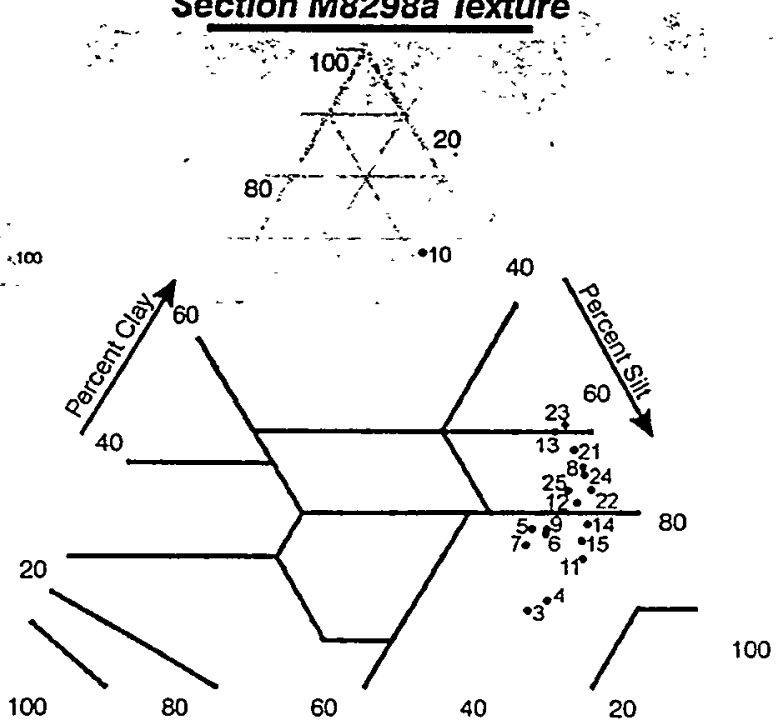

Figure 46. Texture analysis and nomenclature of Sections M8298 and M8298a. Each sediment sample is plotted by unit number onto a diagram of texture nomenclature. Most samples are modified loams, representing a high level of silt, some clay, and less sand. 


\section{Locality M, Section M8298, Terrace 4 Stable Carbon Data $-\delta^{13} \mathrm{C}$}

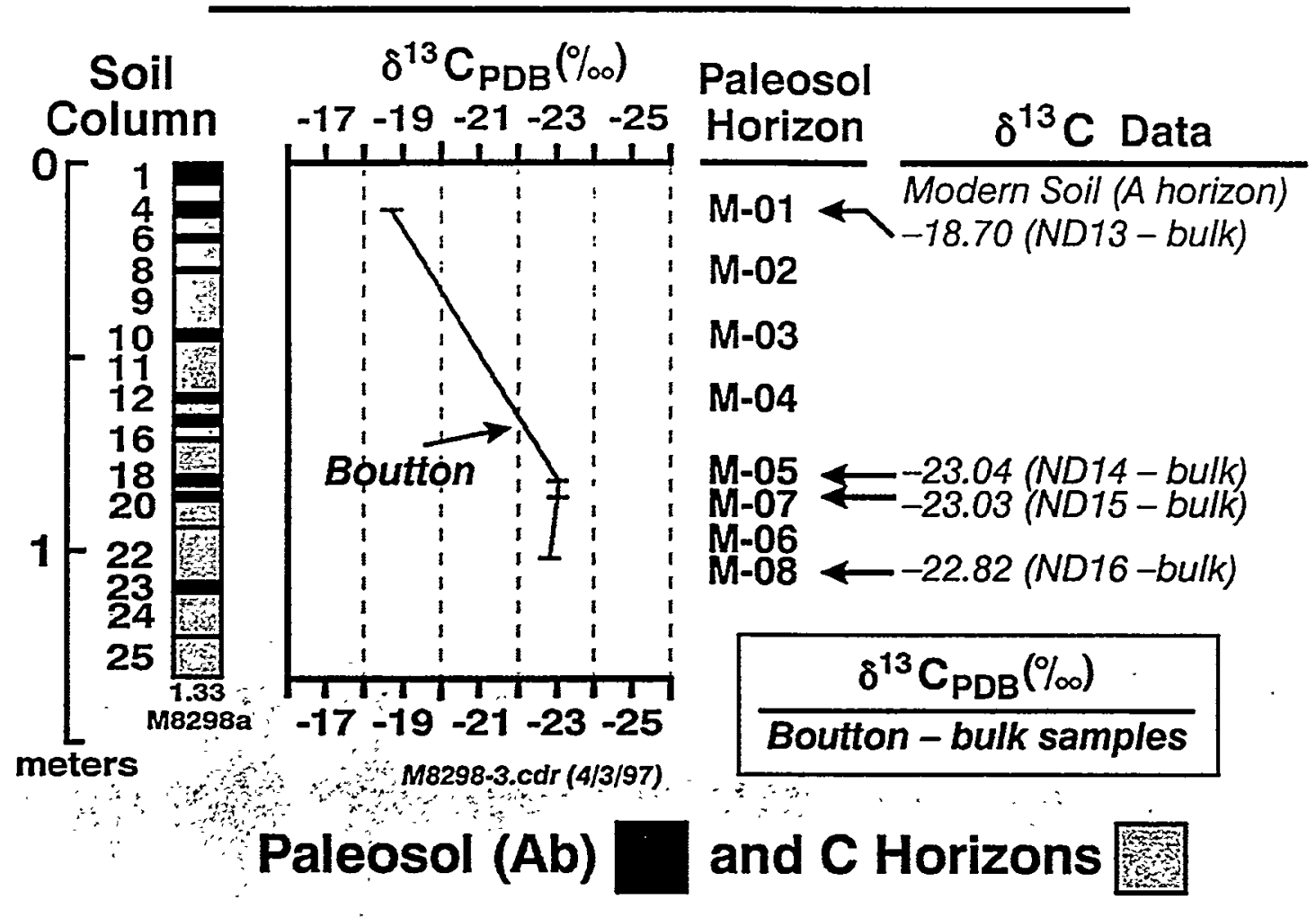

Figure 47. Stable carbon data of Locality $M$ on Terrace 4. Stable carbon values were derived from laboratory analyses by Boutton (written communication, 1996). Boutton's analyses used bulk samples specifically for stable carbon interpretation. Note that the stable carbon curves for Localities D and $\mathrm{M}$ on Terrace 4 are comparable in shape, but with a variation in values. This comparison does suggest that Locality $\mathrm{M}$ may be similar to Locality $\mathrm{D}$ in age. 


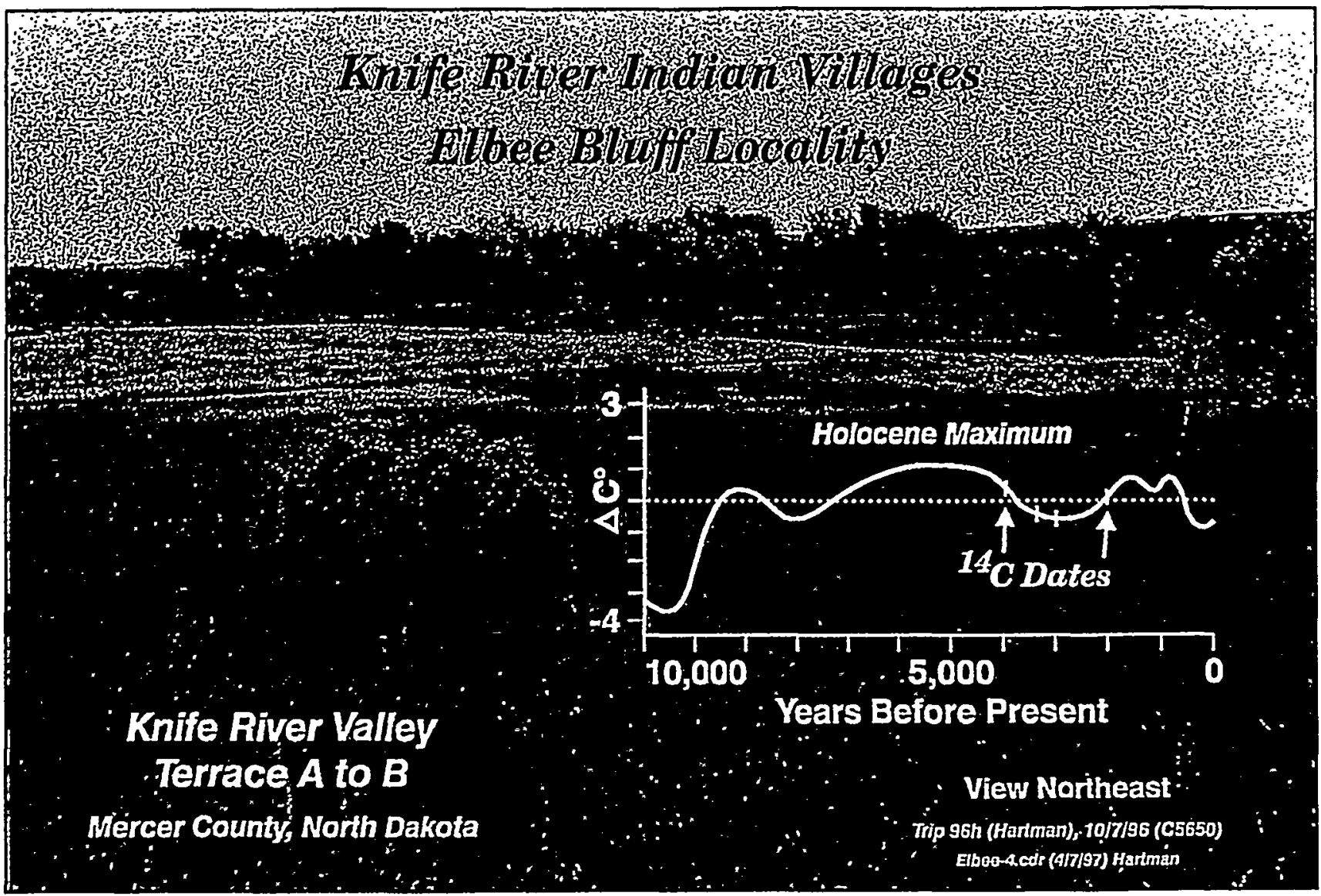

Figure 48. The Elbee Bluff Locality and Terrace $A$ at the Knife River Indian Villages National Historic Site, Mercer County, North Dakota. View across terrace toward Knife River and Elbee Bluff Locality. The approximate age of the Elbee Bluff Locality is illustrated relative to a temperature change curve for the Holocene. The name Elbee Bluff is from Reiten (1983). The interval of time represented by the geologic sections of the project is indicated on the temperature variation curve for the Holocene (from Folland and others, 1991). 


\section{Knife River - Elbee Bluff Locality}

Stanton Quadrangle, Mercer County, North Dakota Knife River Indian Villages National Historic Site

Sec. 28, T. 145 N.. R. 84 W.

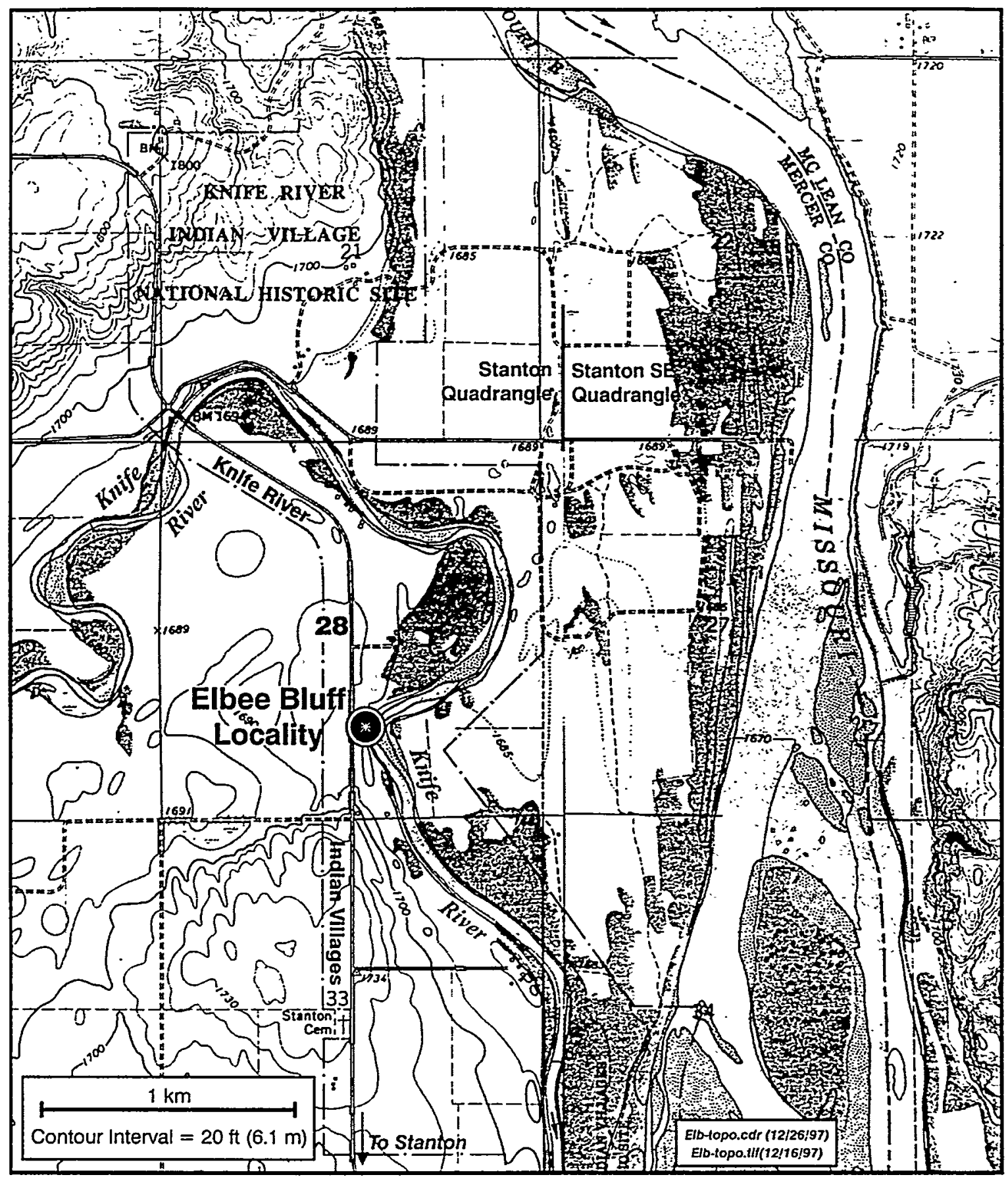

Figure 49. Topographic location map of the Elbee Bluff Locality (Stanton and Stanton SE Quadrangles). 


\section{Knife River - Elbee Bluff Locality}

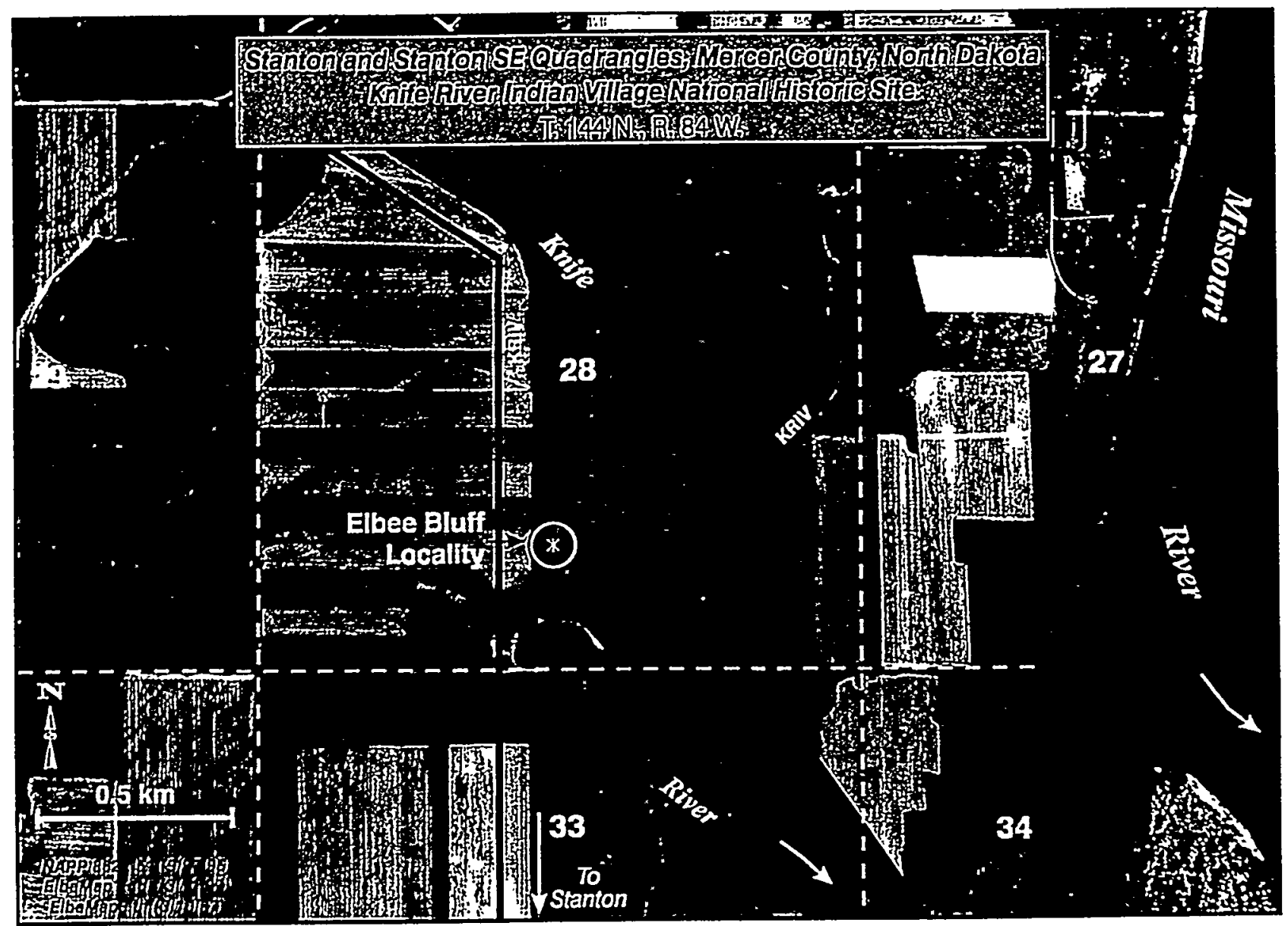

Figure 50. Air photo location map of the Elbee Bluff Locality. The locality is located near the west boundary of the Knife River Indian Villages National Historic Site in eastern Mercer County. The confluence of the alluvial valley of the meandering Knife River with the Missouri River is within $3 \mathrm{~km}(1.9 \mathrm{mi})$ of the south edge of the map. 


\section{Elbee Bluff Locality Section and Terrace A}

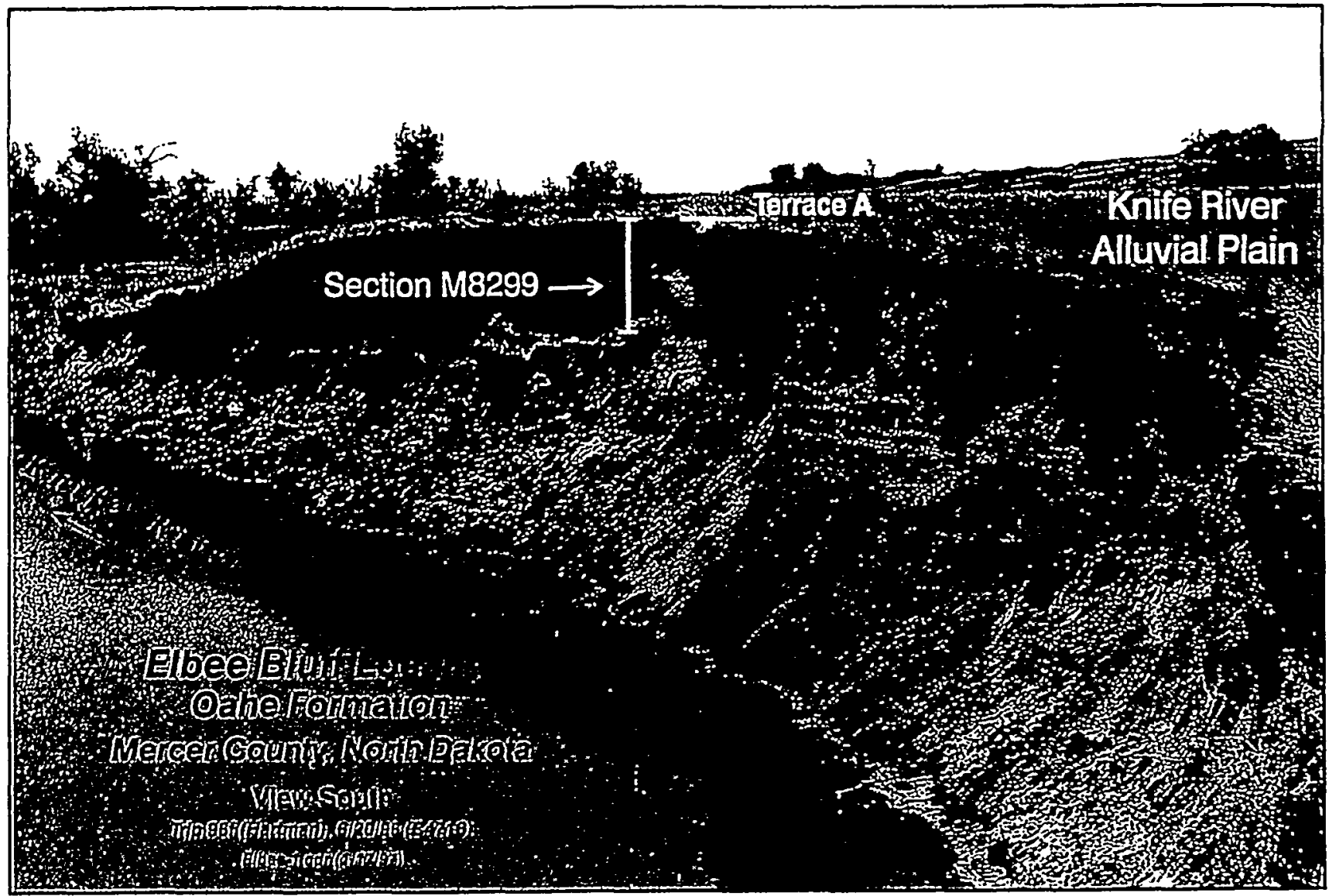

Figure 51. Elbee Bluff Locality, Mercer County, North Dakota. View downstream across the Knife River, a tributary of the Missouri River. This figure illustrates the location of Section M8299 and level of Terrace A (of Reiten, 1983). As this bluff face is actively eroding, the conformation of the exposures changes frequently. 


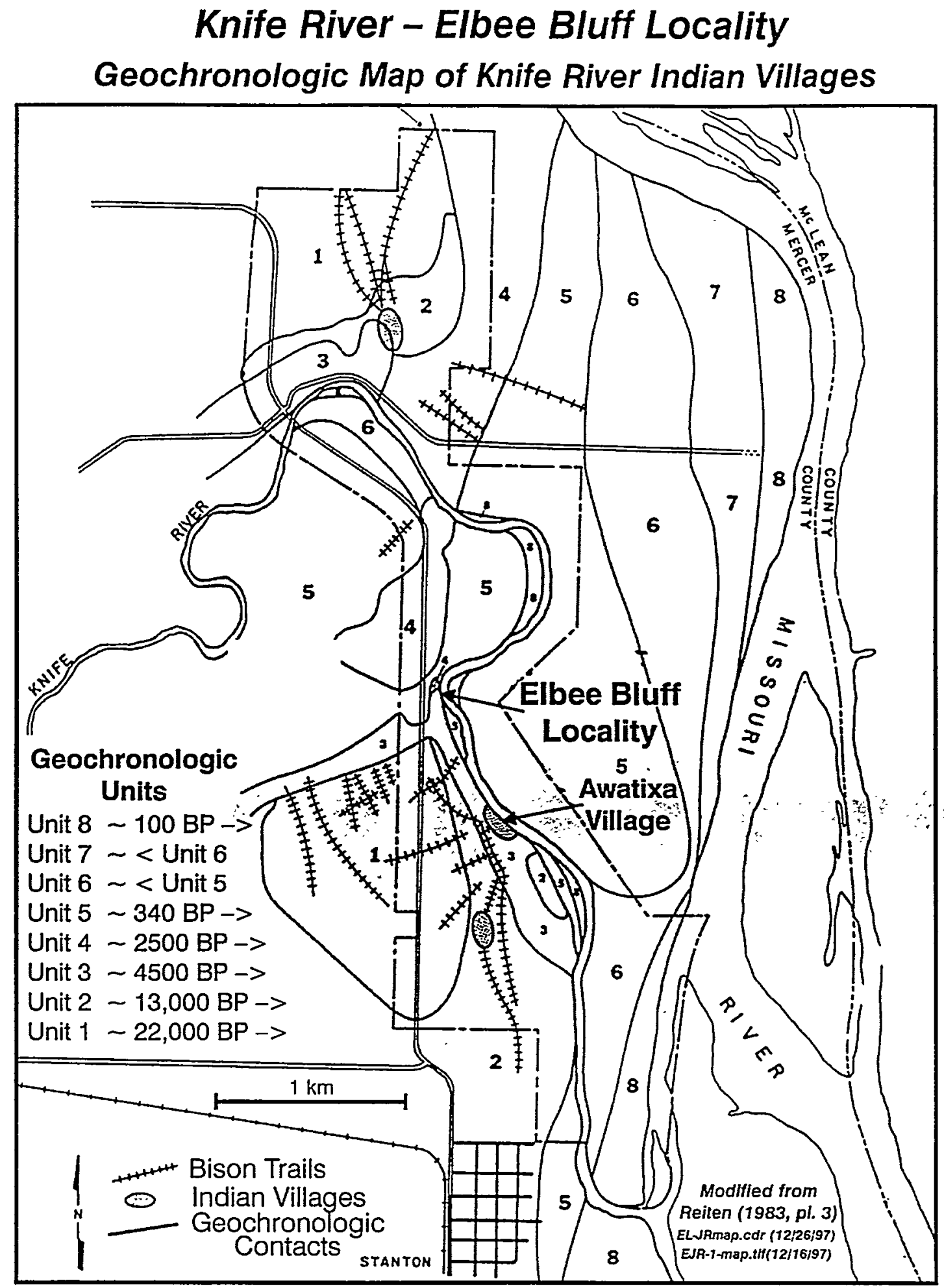

Figure 52. Geochronologic map showing the age of floodplain deposits of the Knife River Indian Villages National Historic Site (after Reiten, 1983, pl. 3). The location of the Elbee Bluff Locality is highlighted. 


\section{Knife River - Elbee Bluff Locality Profile of Section M8299 Area}

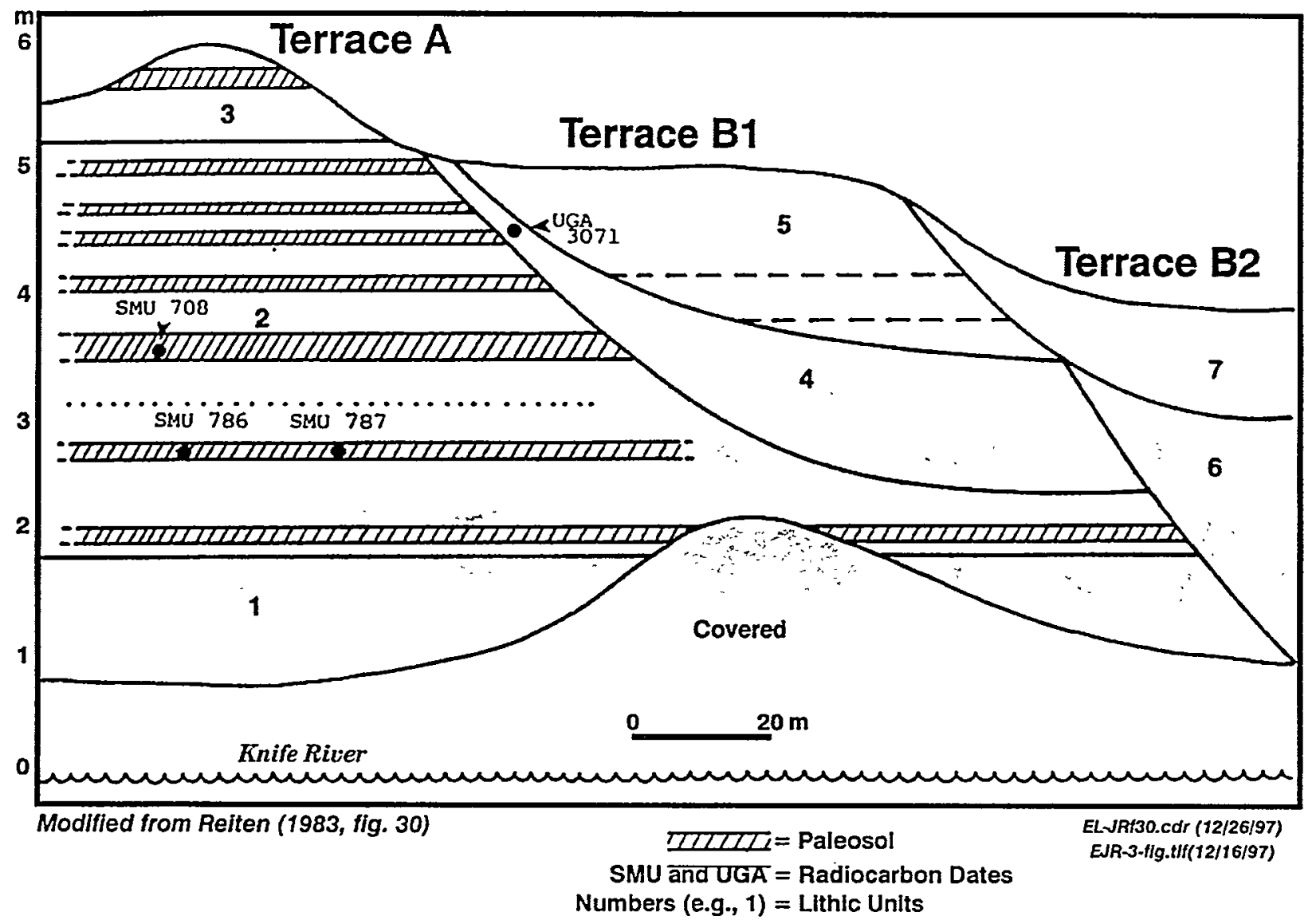

Figure 53. Profile sketch of the Elbee Bluff Locality. This figure shows the relationships of terraces, paleosols, and radiocarbon samples (e.g., UGA, SMU) (after Reiten, 1983, fig. 30). 


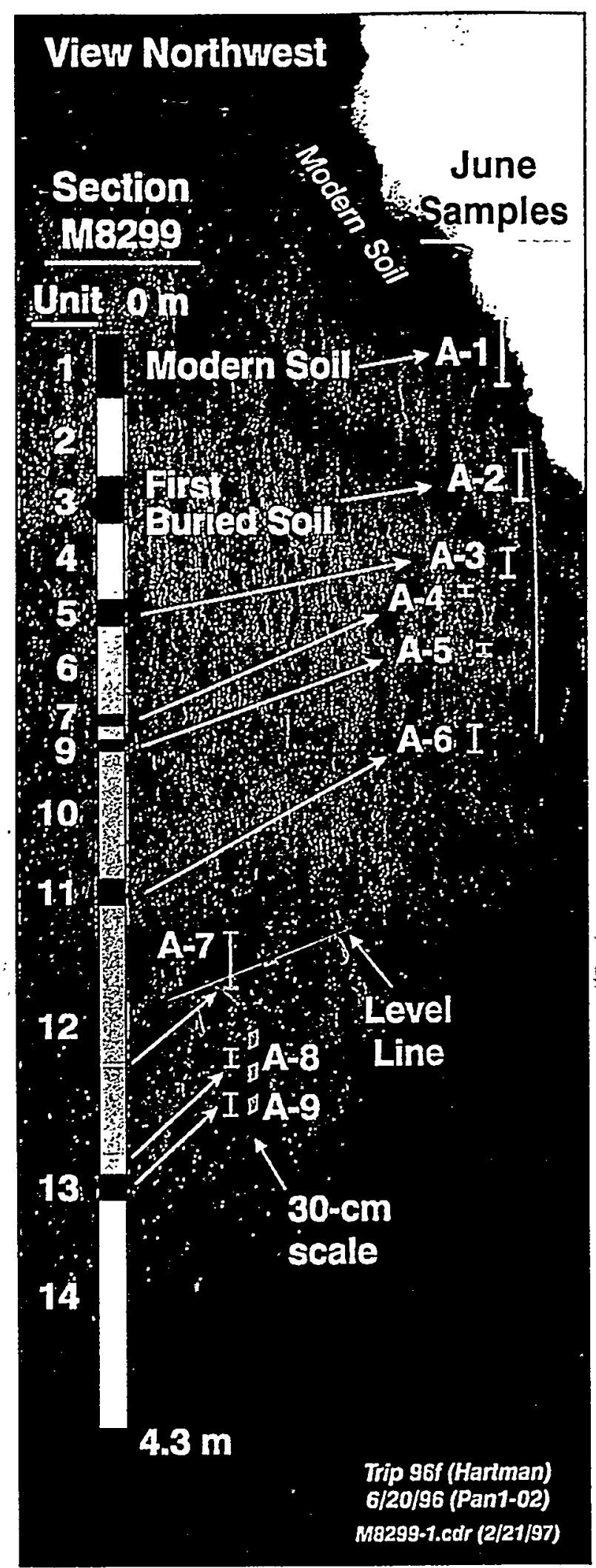

\section{Elbee Bluff Locality Section M8299 Oahe Formation}

Mercer County, North Dakota

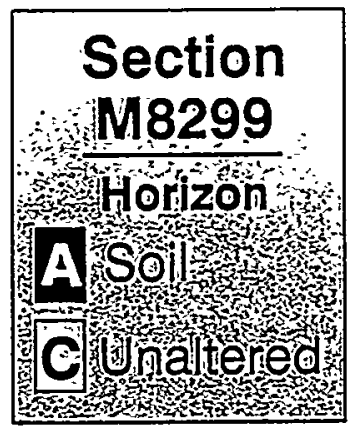

Figure 54. Section M8299 and sample horizons at the Elbee Bluff Locality. This figure illustrates the lithic units (Units 1-14) recognized in this sequence of paleosols and the sampled horizons (e.g., A-1) in June 1996 (Section M8299). Every unit was later resampled in October of 1996 (Section M8299a). 


\section{Elbee Bluff Locality Section and Terrace A}

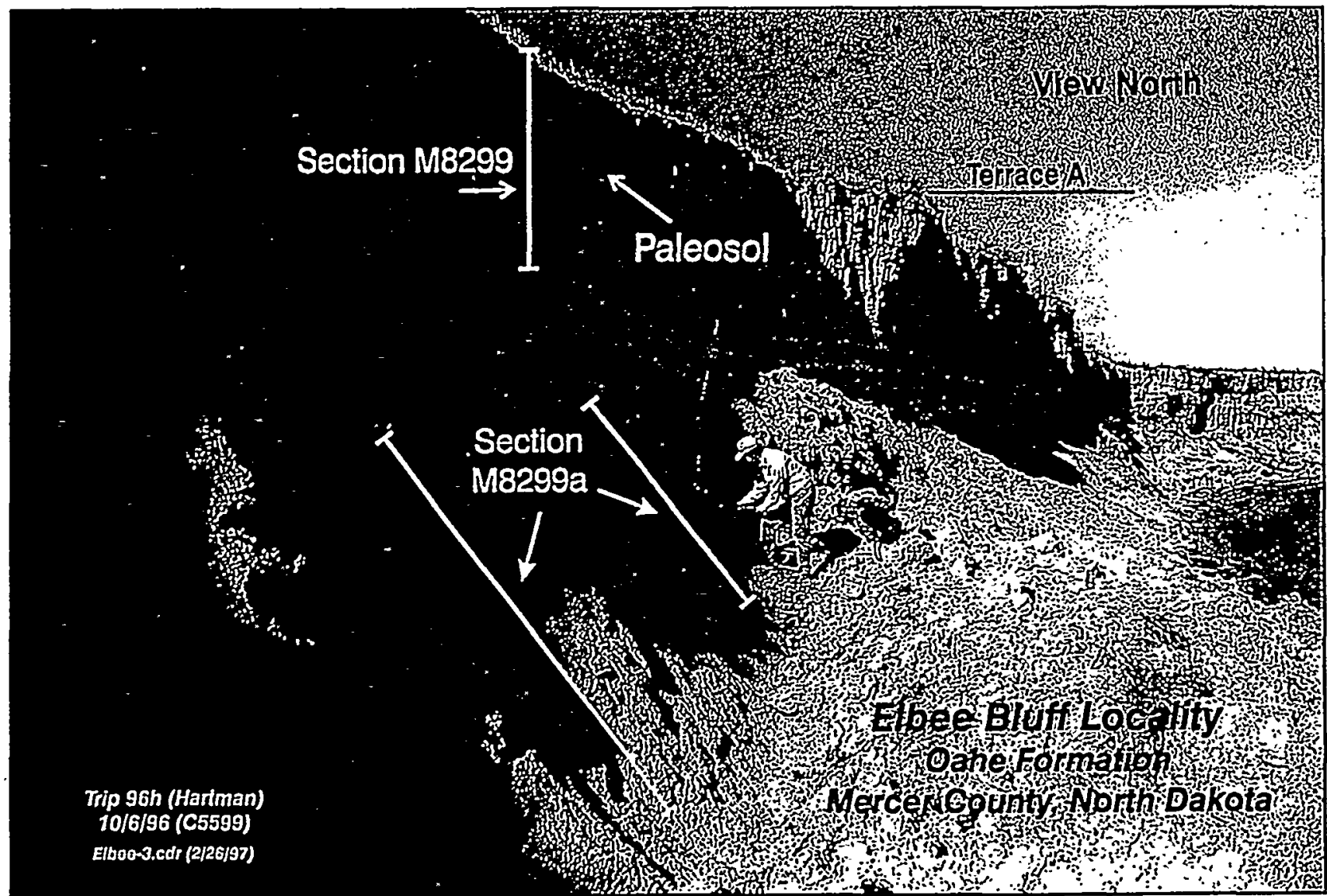

Figure 55. Elbee Bluff Locality sections and terrace. View upstream of worked cutbank exposures. Section M8299 was sampled and described in June 1996, and Section M8299a was studied in October of the same year. Section M8299a is on a large, undistorted block that has rotated away from the slump face. 


\section{Elbee Bluff Locality, Section M8299, Terrace A Correlation of Section Units}

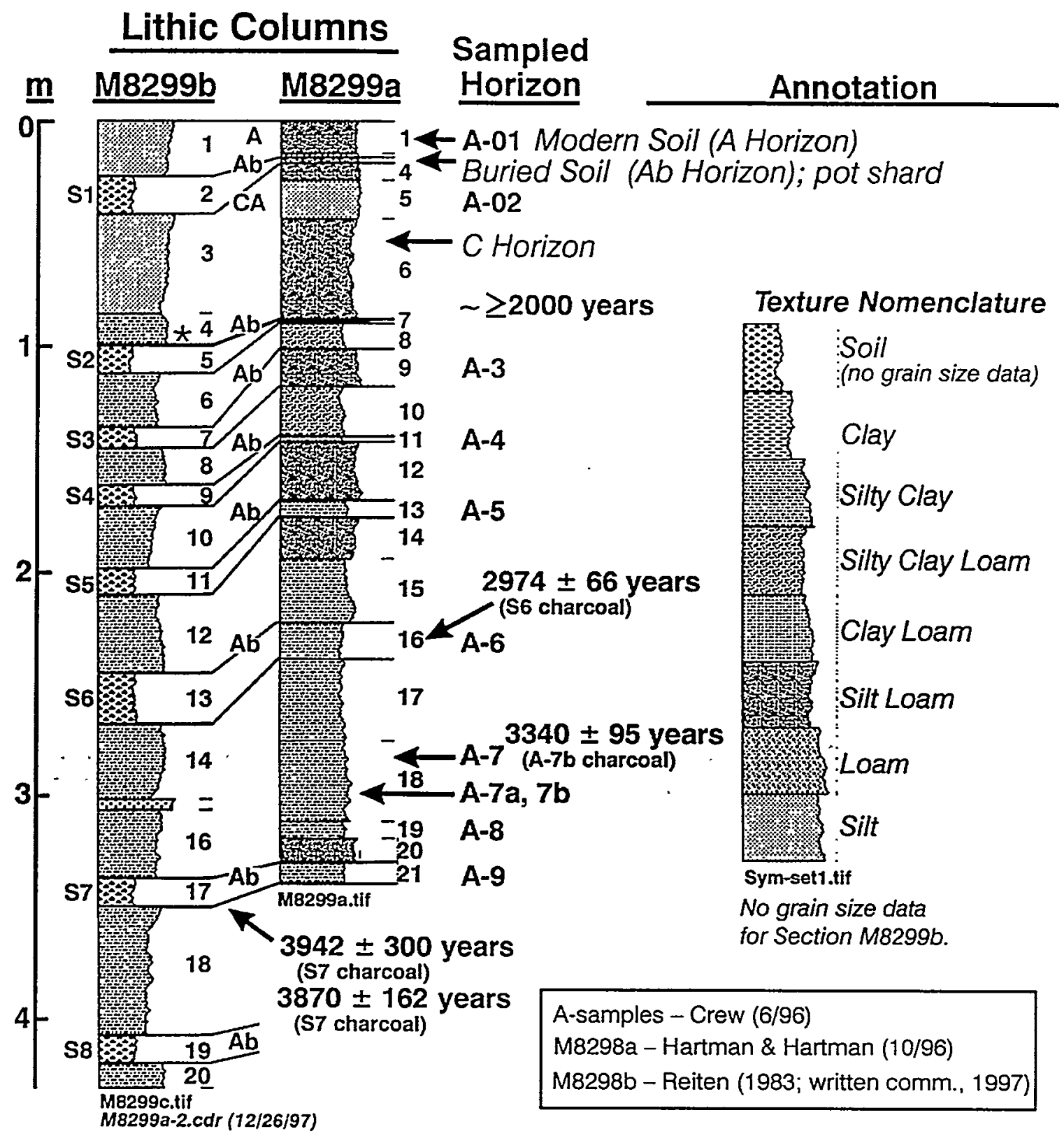

Figure 56. Correlation of Terrace A Sections M8299a and M8299b. This figure represents the correlation of lithologies between sections measured by Reiten (1983; Section M8299b is modified from Reiten fig. 30) and Hartman and Hartman (10/96, M8299a). This figure includes the sampled horizons and associated radiocarbon dates (* and S6 and S7 are dates from Reiten, 1983). The S-numbers of Section M8299b represent buried soils numbered by Reiten (1983). 


\section{Texture Nomenclature for Sections M8299 and M8299a}

\section{Section M8299 Texture}

100

20

80
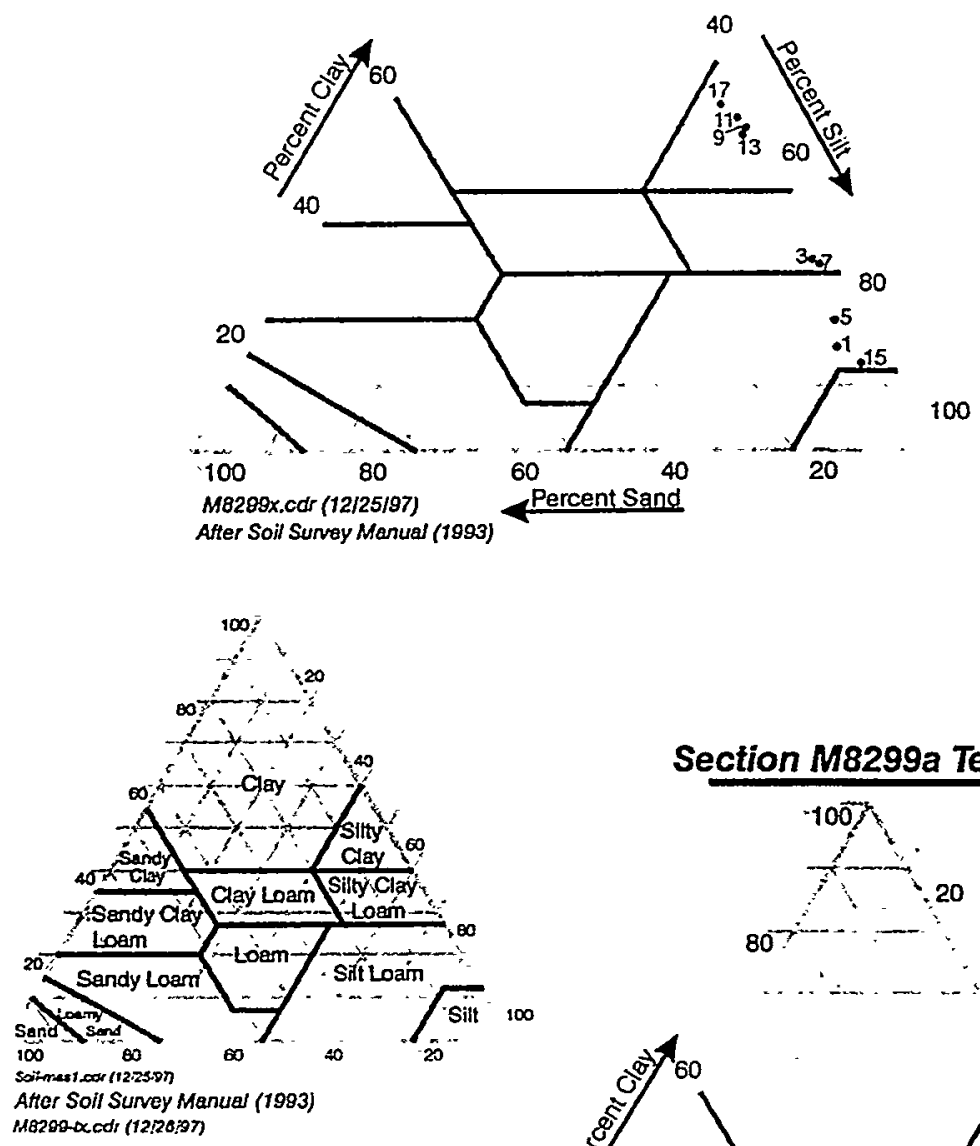

Section M8299a Texture

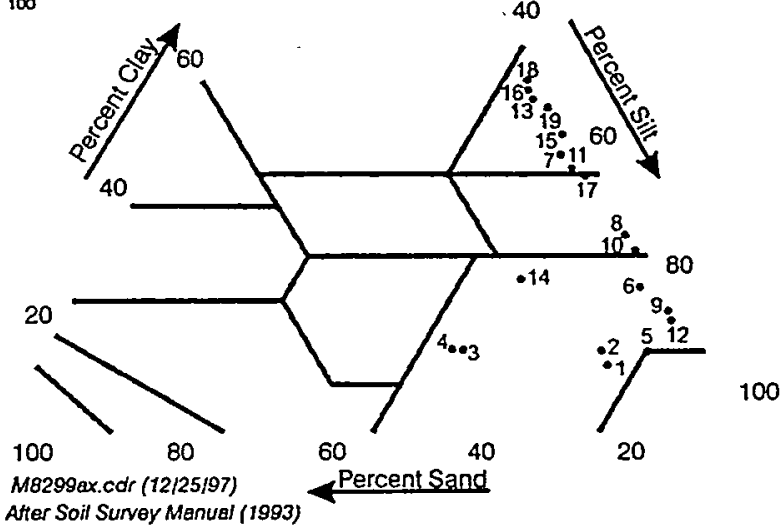

Figure 57. Texture analysis and nomenclature of Sections M8299 and M8299a. Each sediment sample is plotted by unit number onto a diagram of texture nomenclature. Many of the samples are modified loams, representing a high level of silt, some clay, and less sand. Unlike other localities, silty clay sediments are also relatively common. 
Elbee Bluff Section M8299

Stable Carbon Data $-\delta^{13} \mathrm{C}$

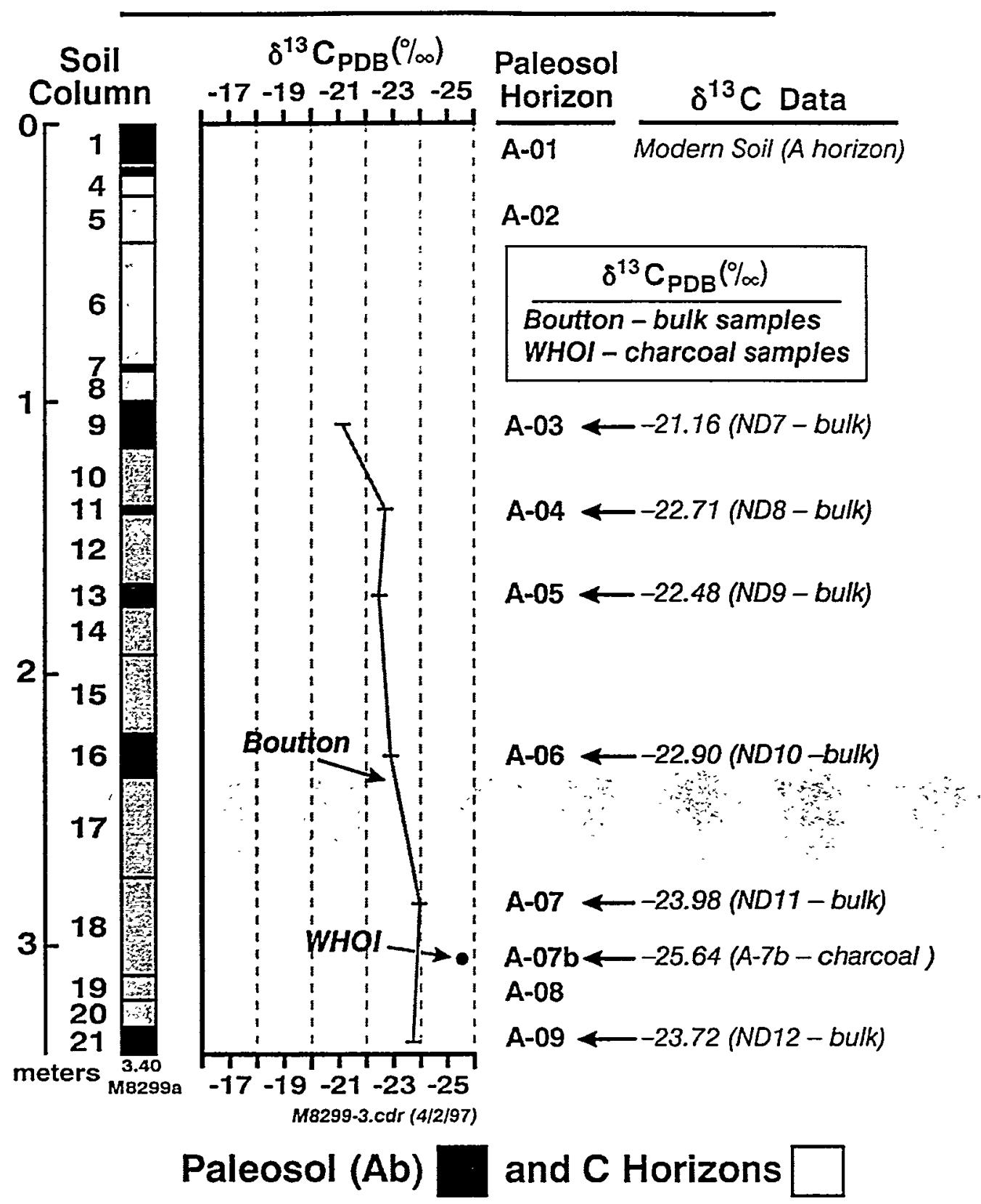

Figure 58. Stable carbon data of the Elbee Bluff Locality. Stable carbon values were derived from laboratory analyses by Boutton (written communication, 1996) and by WHOI (written communication, 1997). The values between these two groups of analyses are not directly comparable, as different processes and fractionation procedures were employed. Boutton's analyses used bulk samples specifically for stable carbon interpretation, whereas the WHOI sample was analyzed on a small charcoal sample to derive a radiocarbon date. 


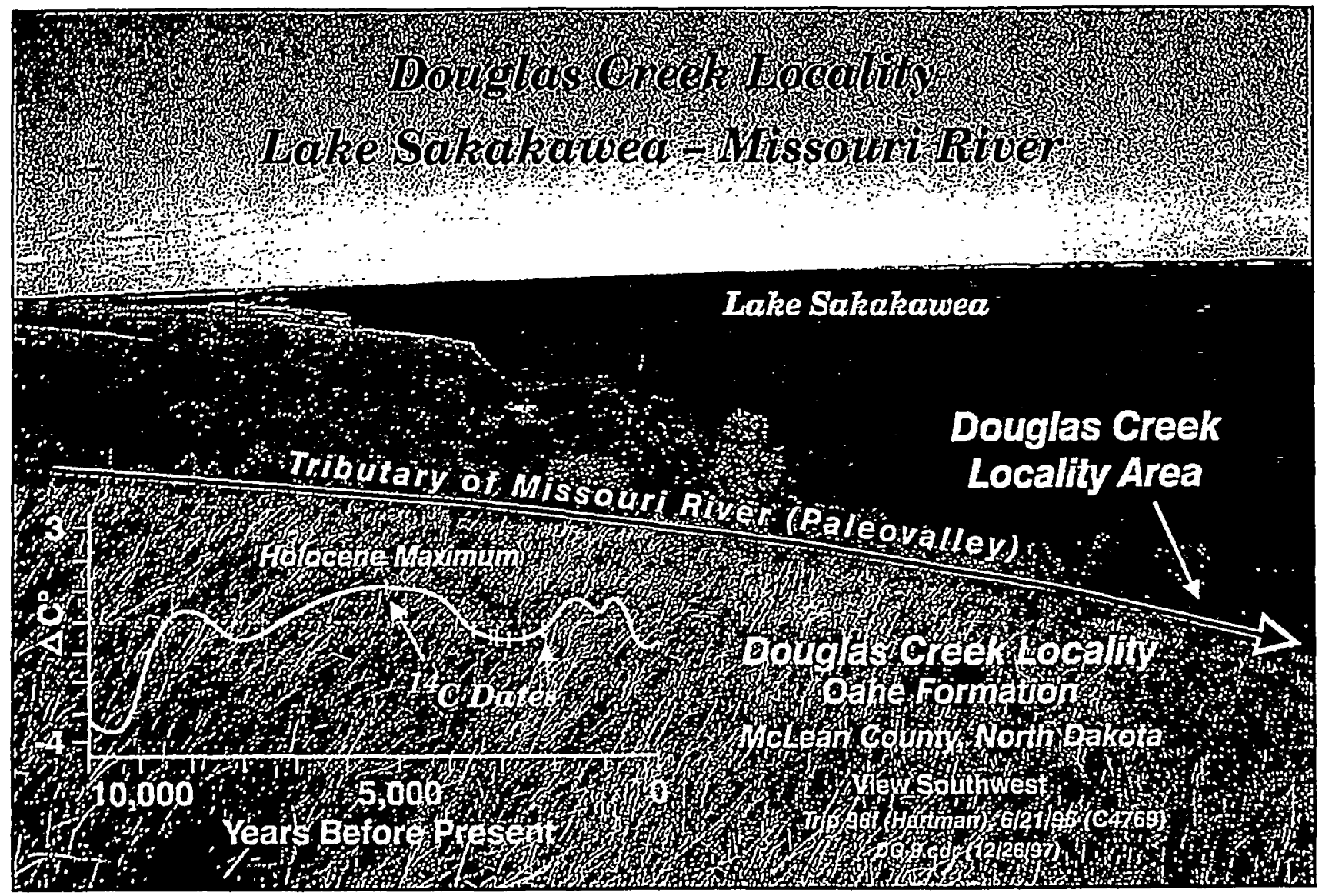

Figure 59. The Douglas Creek Locality on Lake Sakakawea (Missouri River), McLean County, North Dakota. View of upland surface across tributary valley of Missouri River encompassing, below, the Douglas Creek sections. The approximate age of the Douglas Creek Locality is illustrated relative to a temperature change curve for the Holocene. The Douglas Creek Locality is named after the North Dakota Douglas Creek State Game Management Area, which includes this site. The bedrock of the upland surface is the Paleocene-age Sentinel Butte Formation. 


\section{Douglas Creek Locality}

\section{Emmet SE Quadrangle, McLean County, North Dakota Douglas Creek State Game Management Area}

Sec. 11, T. 147 N., R. 86 W.

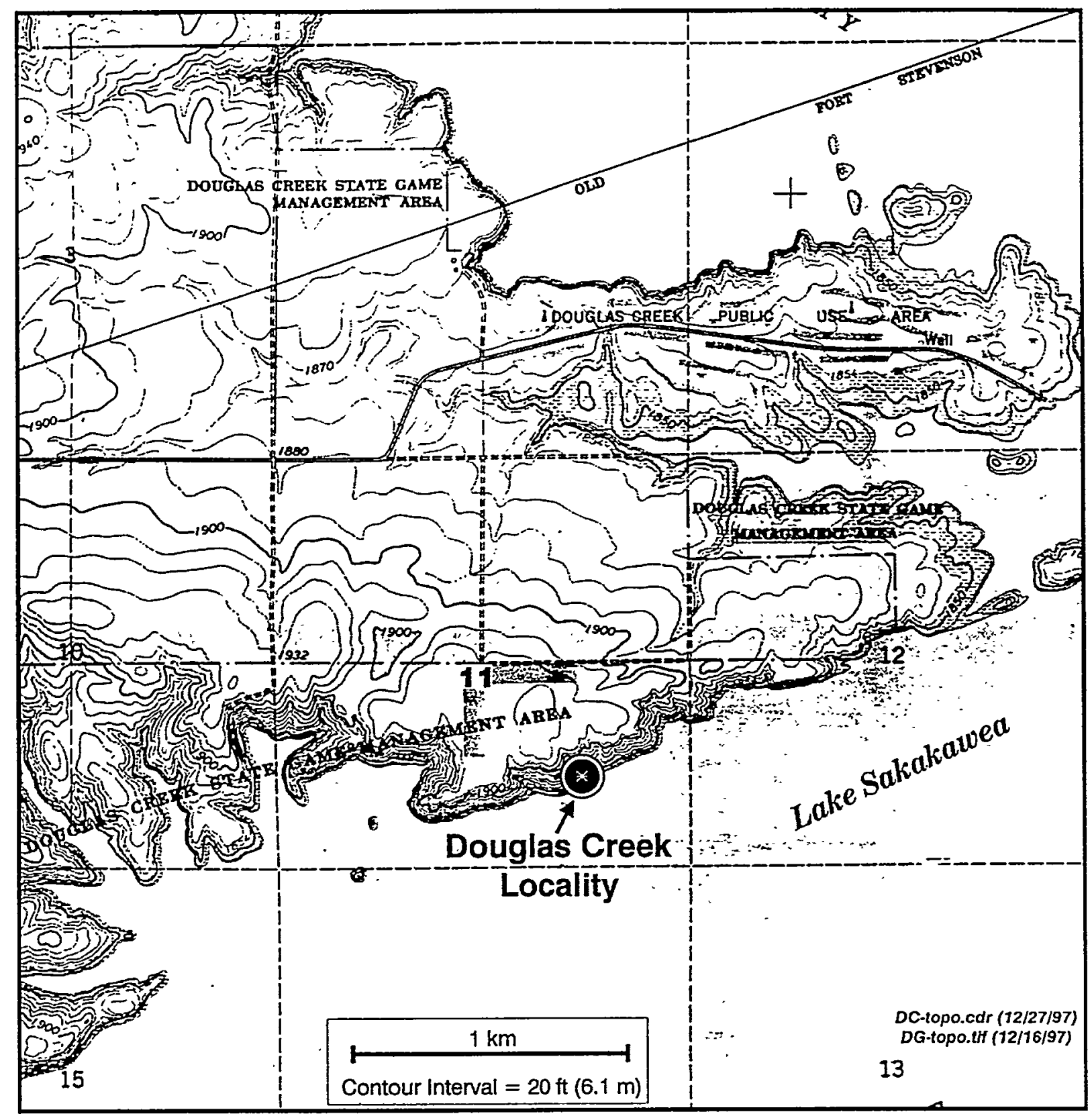

Figure 60. Topographic location map of the Douglas Creek Locality (Emmet SE Quadrangle). 


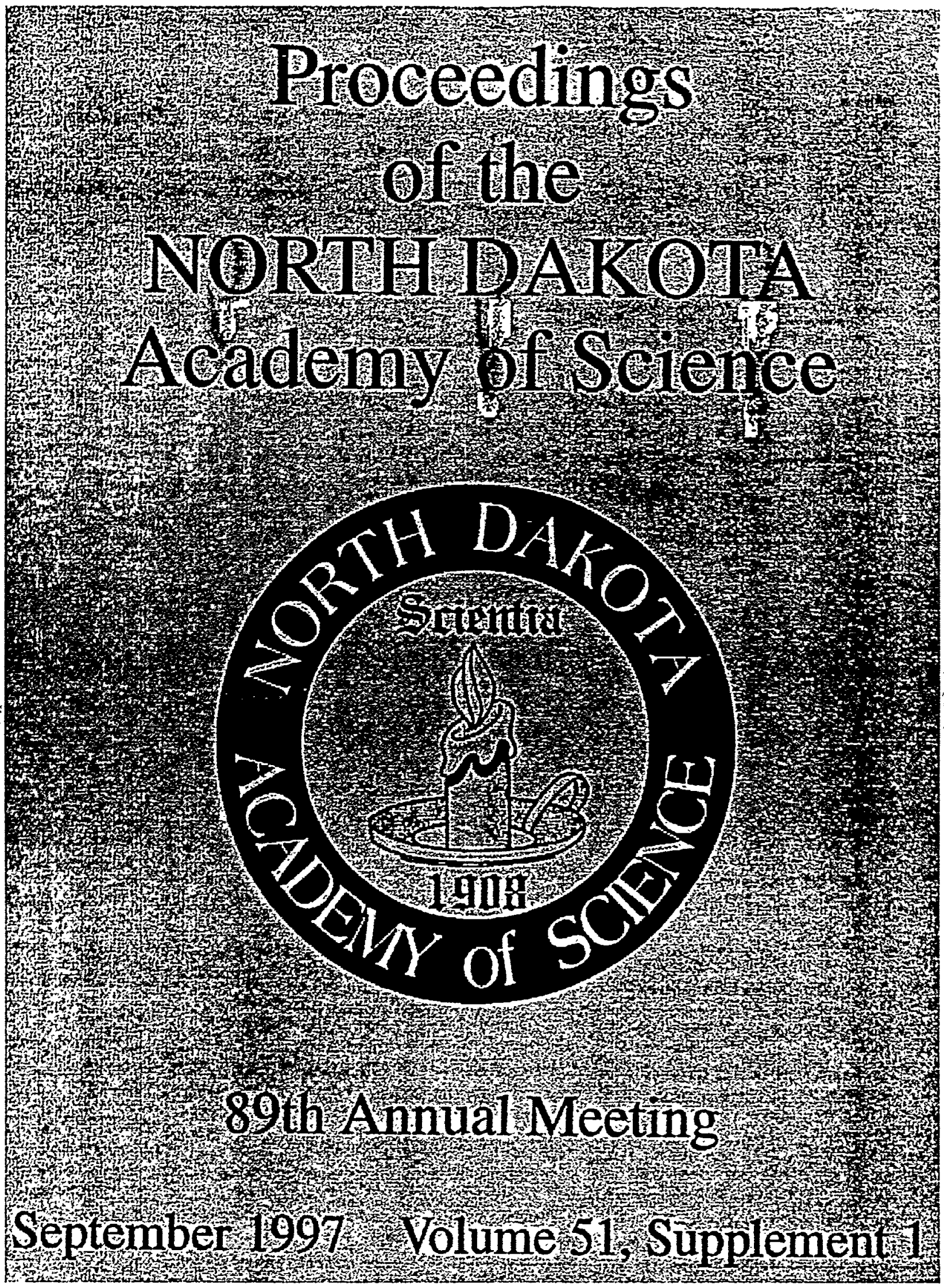




\section{Douglas Creek Sections}

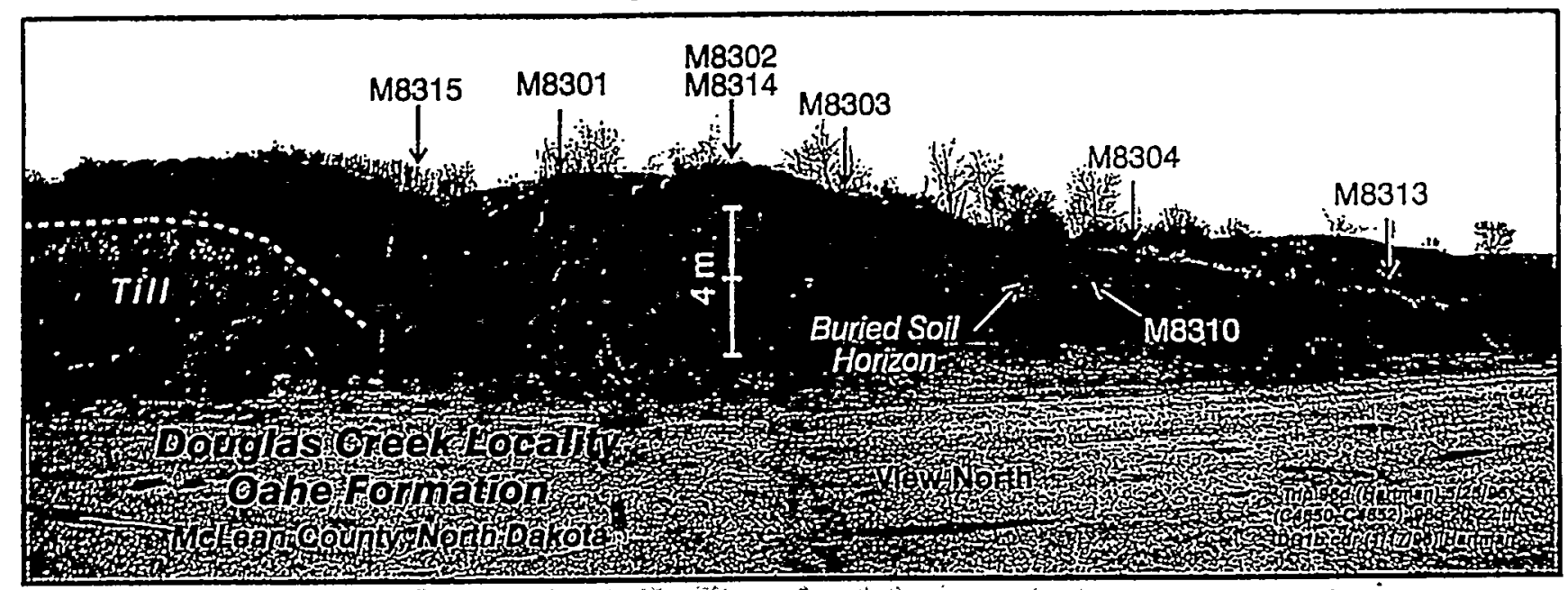

Figure 62. Douglas Creek Locality sections. View across swash zone of eroding cutbank exposures. Significant geologic sections include M8301 M8304, with other M-numbered geological observations (see AbBreviations, p. 13). Section M8302 represents the thickest section, and all radiocarbon dates are correlated to it The Holocene Oahe Formation locally overlies either glacial deposits of the Pleistocene Coleharbor Formation or the Paleocene Sentinel Butte Formation (about $57 \mathrm{Ma}$ ). This shoreline has since been ravaged by the high waters of Lake Sakakawea, but note that a condensed paleosol section is seen above the till to the west. 


\section{Douglas Creek Locality \\ Holocene Paleosols and Paleocene Bedrock}

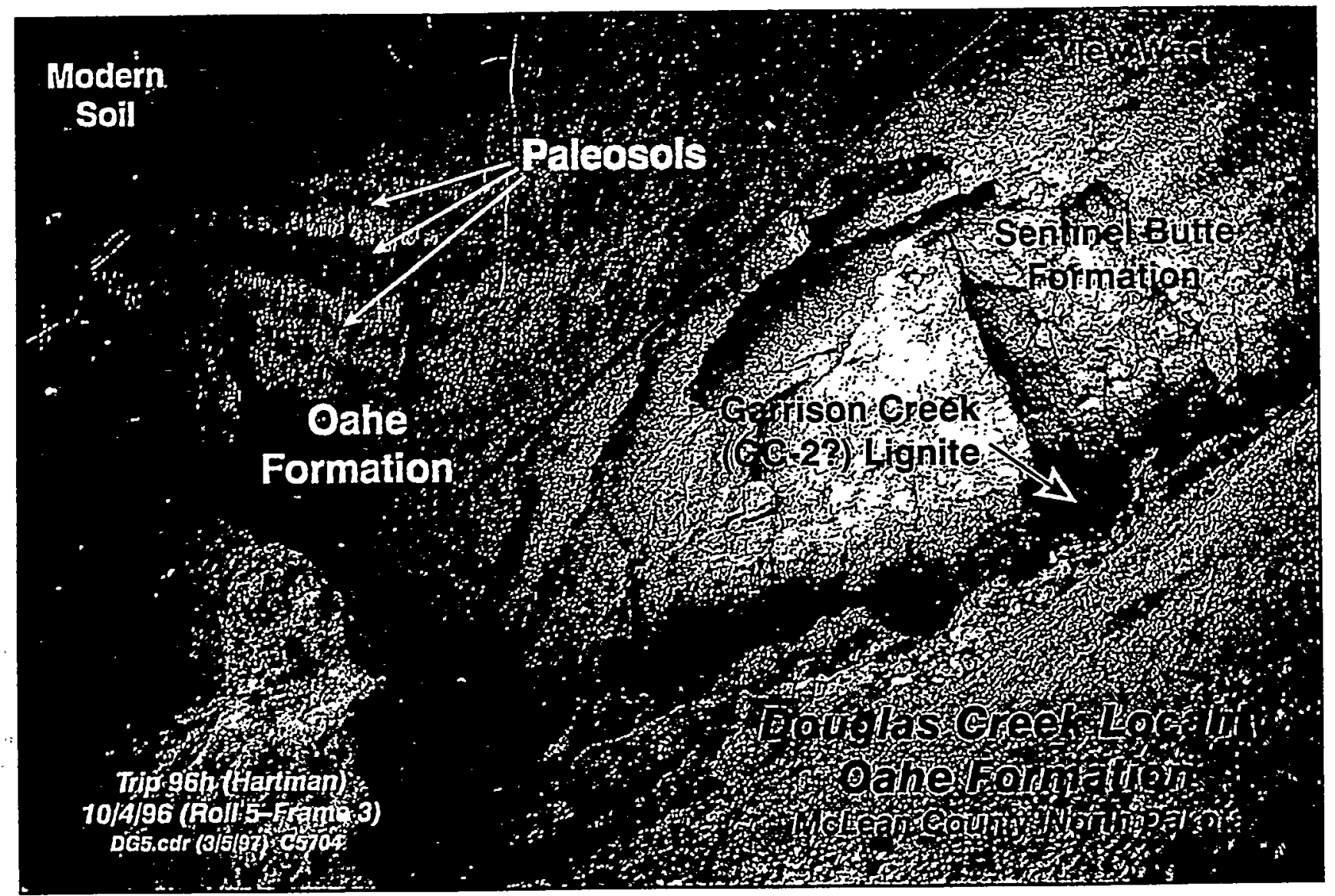

Figure 63. Oahe (Holocene) and Sentinel Butte (Paleocene) formational contact at the Douglas Creek Locality. This view shows a slumped section of the Sentinel Butte Formation with a distorted and thinned bed of the Garrison Creek lignite. The Douglas Creek paleosols of the Oahe Formation can be seen trending to the south, down the valley. This exposure represents the headwall of the tributary and paleosols. Carbon clasts from the Garrison Creek lignite bed create a source of contamination in radiocarbon dating, stable carbon analysis, and total organic carbon analysis. 


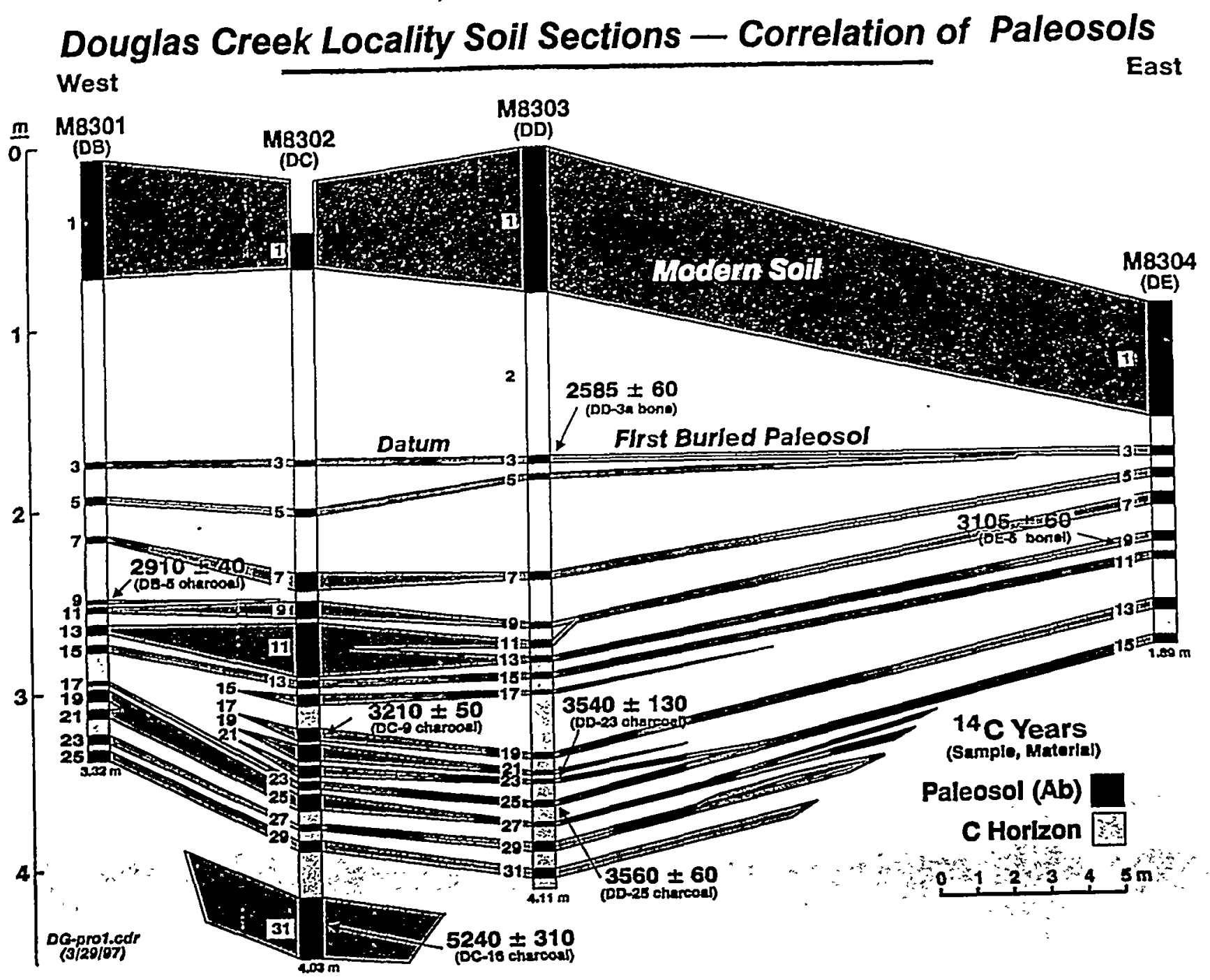

Figure 64. Correlation of Douglas Creek Locality sections. This correlation profile includes the four main sections at this locality (M8301-M8304), and all of the paleosols were traced laterally across the valley. The thickest paleosols are in the center of the valley (Section M8302). Note that the thickness of the beds lateral to Section M8303 does not decrease. The first buried paleosol is used as a datum for portraying the occurrence of the measured sections. Radiocarbon dates are shown with their sample numbers where their respective samples were collected. All numbers on the sides of the sections represent unit numbers (e.g., Section M8302 contains 31 units). 


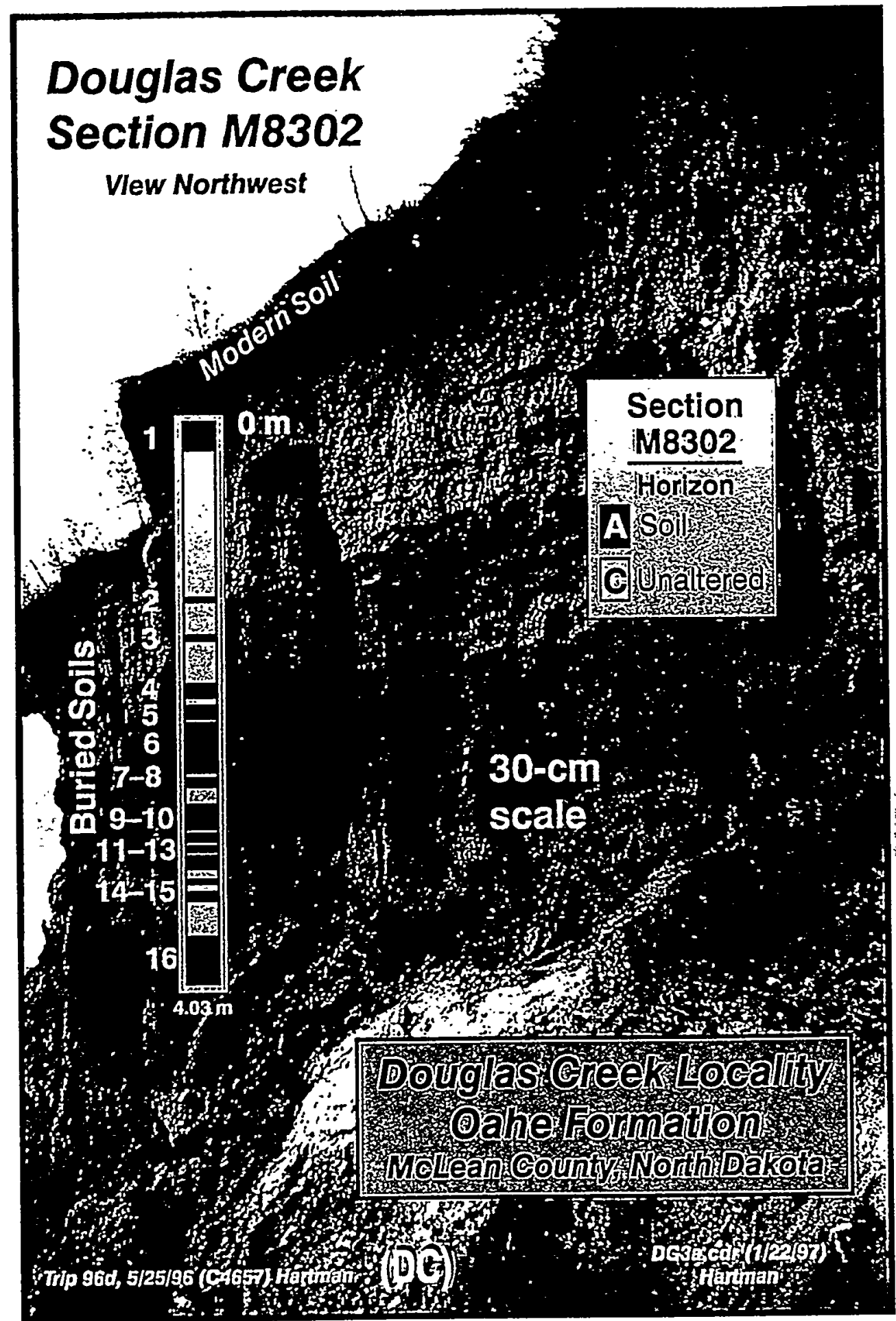

Figure 65. Douglas Creek Locality Section M8302. This section represents the most-analyzed paleosol sequence at the Douglas Creek Locality. 


\section{Douglas Creek Locality - Bone Fragments}

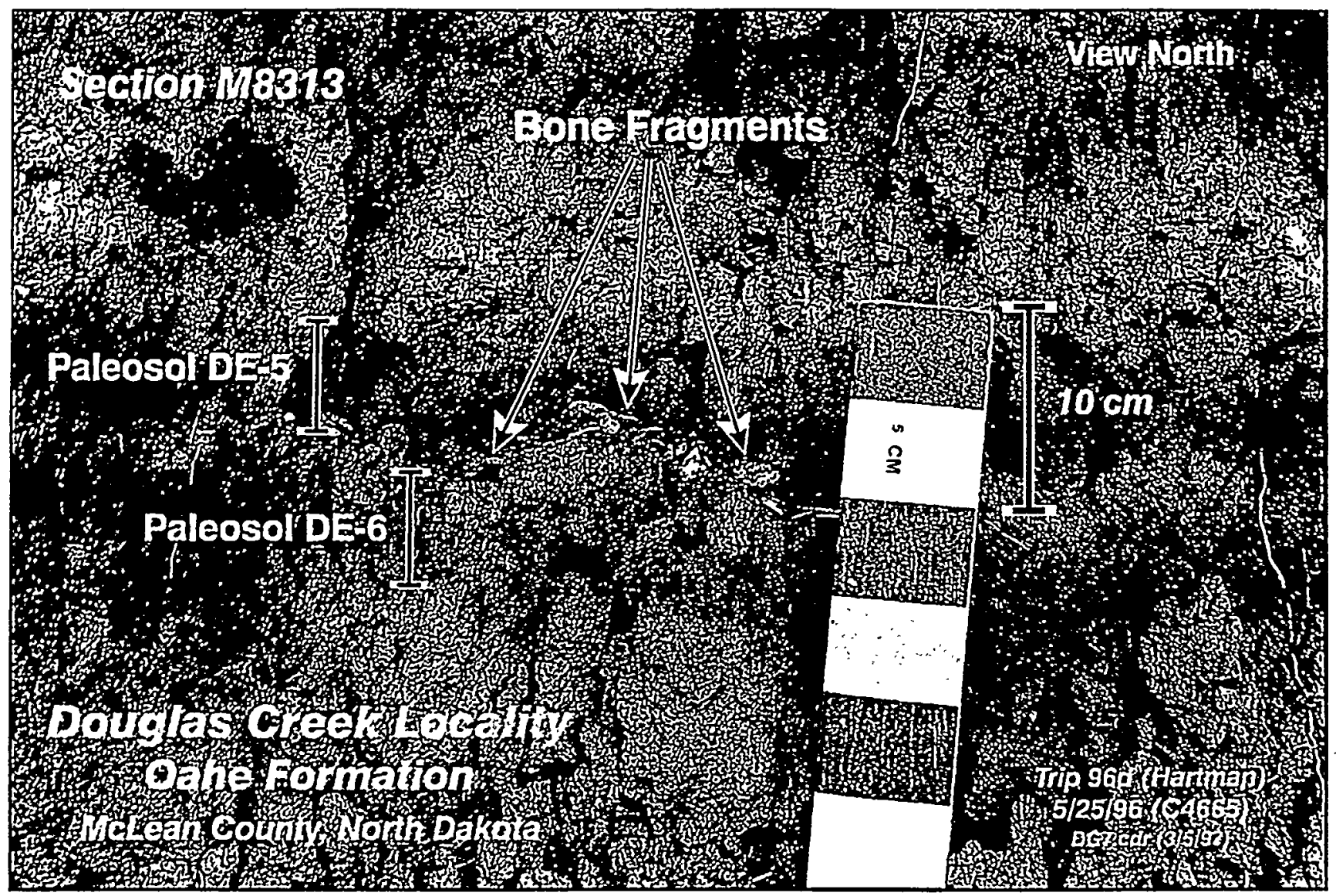

Figure 66. Section M8302 and sample horizons at the Douglas Creek Locality. This figure illustrates the lithic units (Units 1-31) recognized in this sequence of paleosols and the sampled horizons (e.g., DC-1 to DC-16) in June 1996. Paleosols in other sections were directly correlated with this section. All radiocarbon dates are correlated with Section $\mathrm{M} 8302$, including multiple analyses on charcoal or bone from the same sample. 


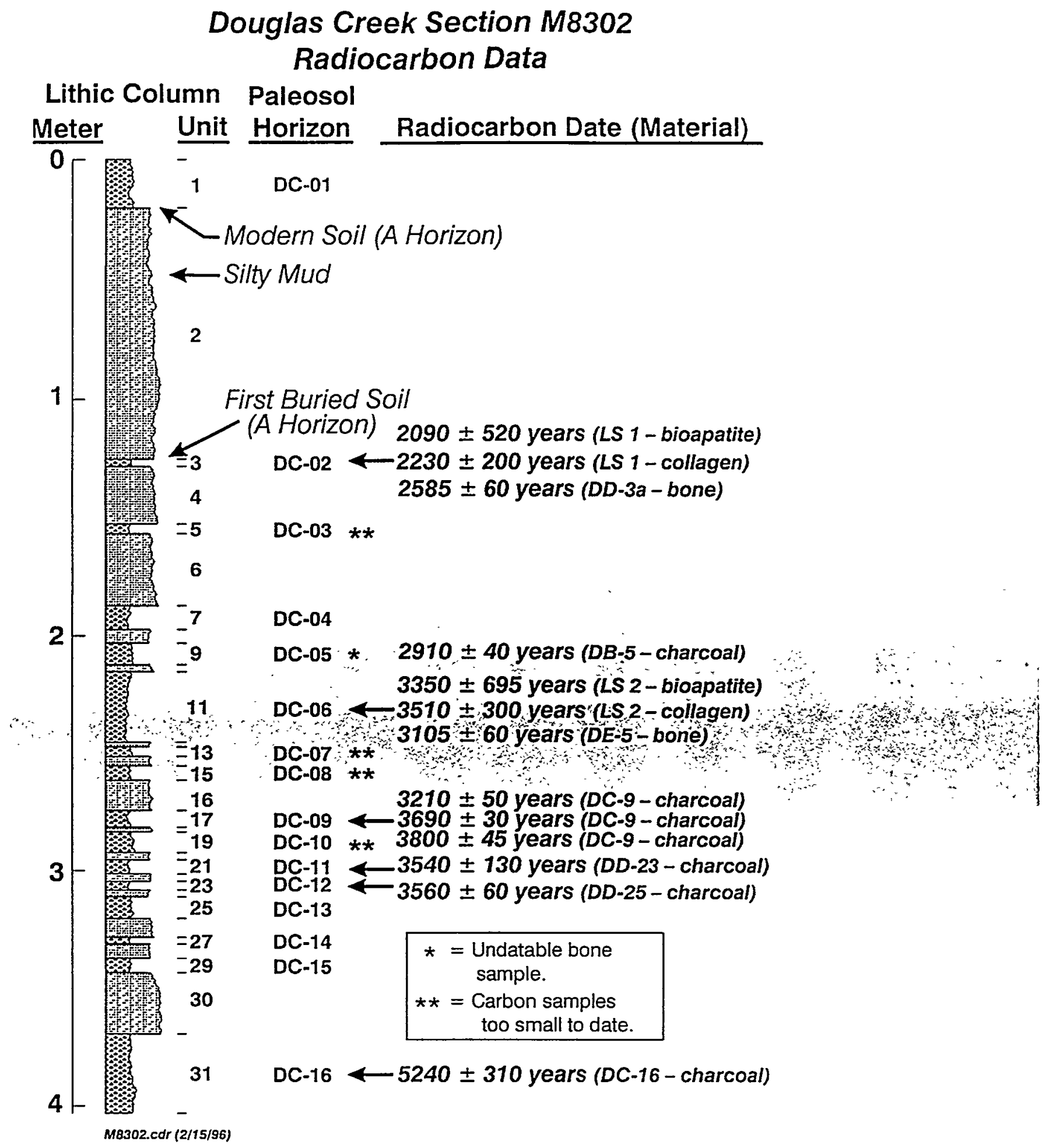

Figure 67. Bone fragments in paleosols from the Douglas Creek Locality. This closeup in situ view illustrates Bison bone found in a few layers. A number of Bison teeth and bone fragments were found as float in shoreline deposits. In situ bones did not represent good material for radiocarbon dating, as the collagen was effectively replaced. 


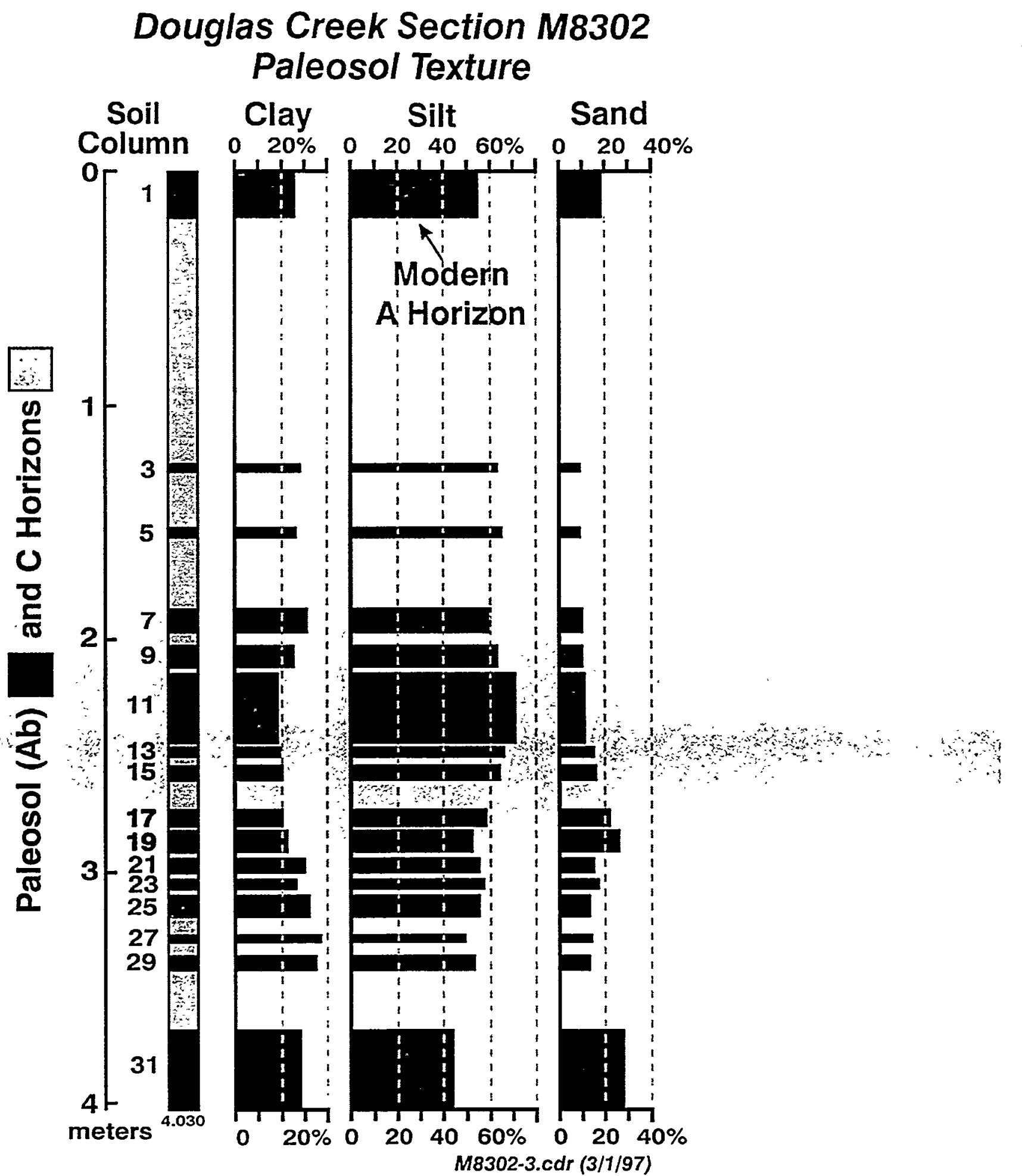

Figure 68. Texture analysis profile of Section M8302. The percentage of clay, silt, and sand is shown as histograms for the 15 paleosols and modern soil of Section M8302. Certain trends in grain size are noted, but their significance is uncertain (increase in silt through Unit 11 and possible fining-upwards of the sediment in the remaining paleosols). 


\section{Texture Nomenclature for Section M8302}

\section{Section M8302 Texture}

100

20

80

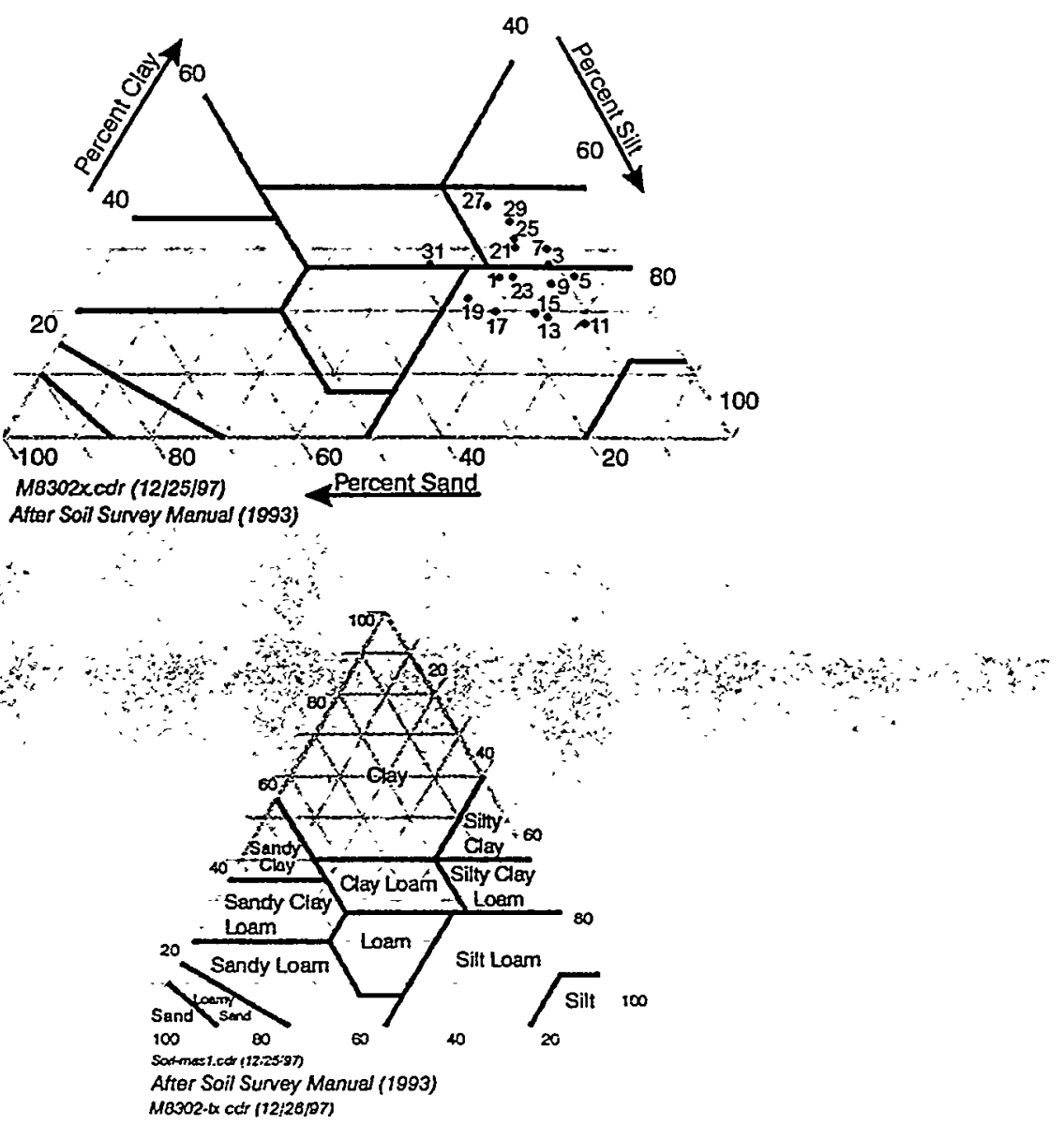

Figure 69. Texture analysis and nomenclature of Section M8302. Each sediment sample is plotted by unit number onto a diagram of texture nomenclature. All samples are modified loams, representing a high level of silt and some clay and sand. 


\section{Douglas Creek Locality - Pebble Lens}

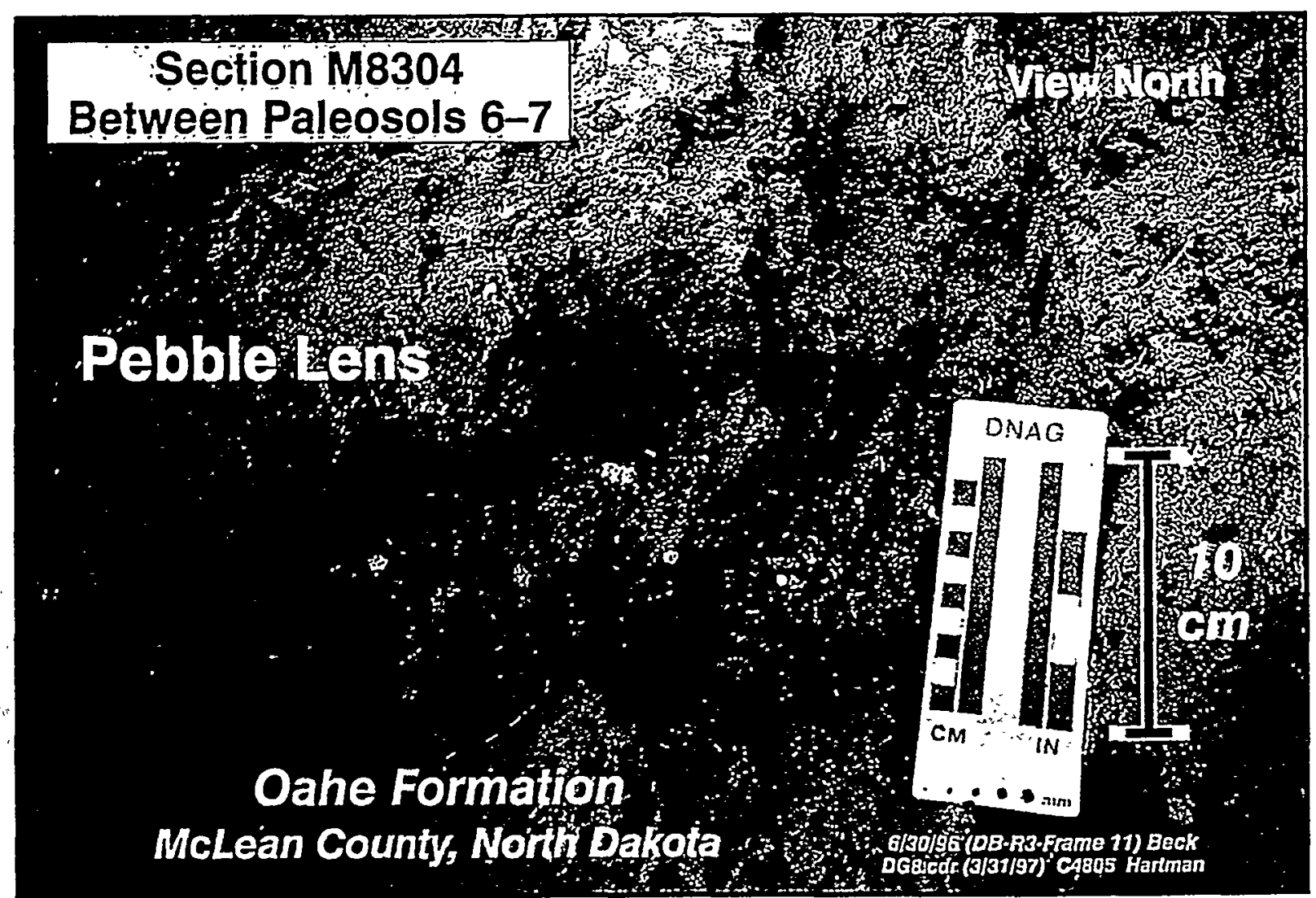

Figure 70. Pebble lens in $\mathbf{C}$ horizon at the Douglas Creek Locality. This view includes a pebble lens at the base of a $\mathrm{C}$ horizon. Pebble lenses are sporadic, but common, at the Douglas Creek Locality. Lenses include pebbles undoubtedly derived from local glacial till sources and represent higher-flow regimes during alluvial sedimentation. 


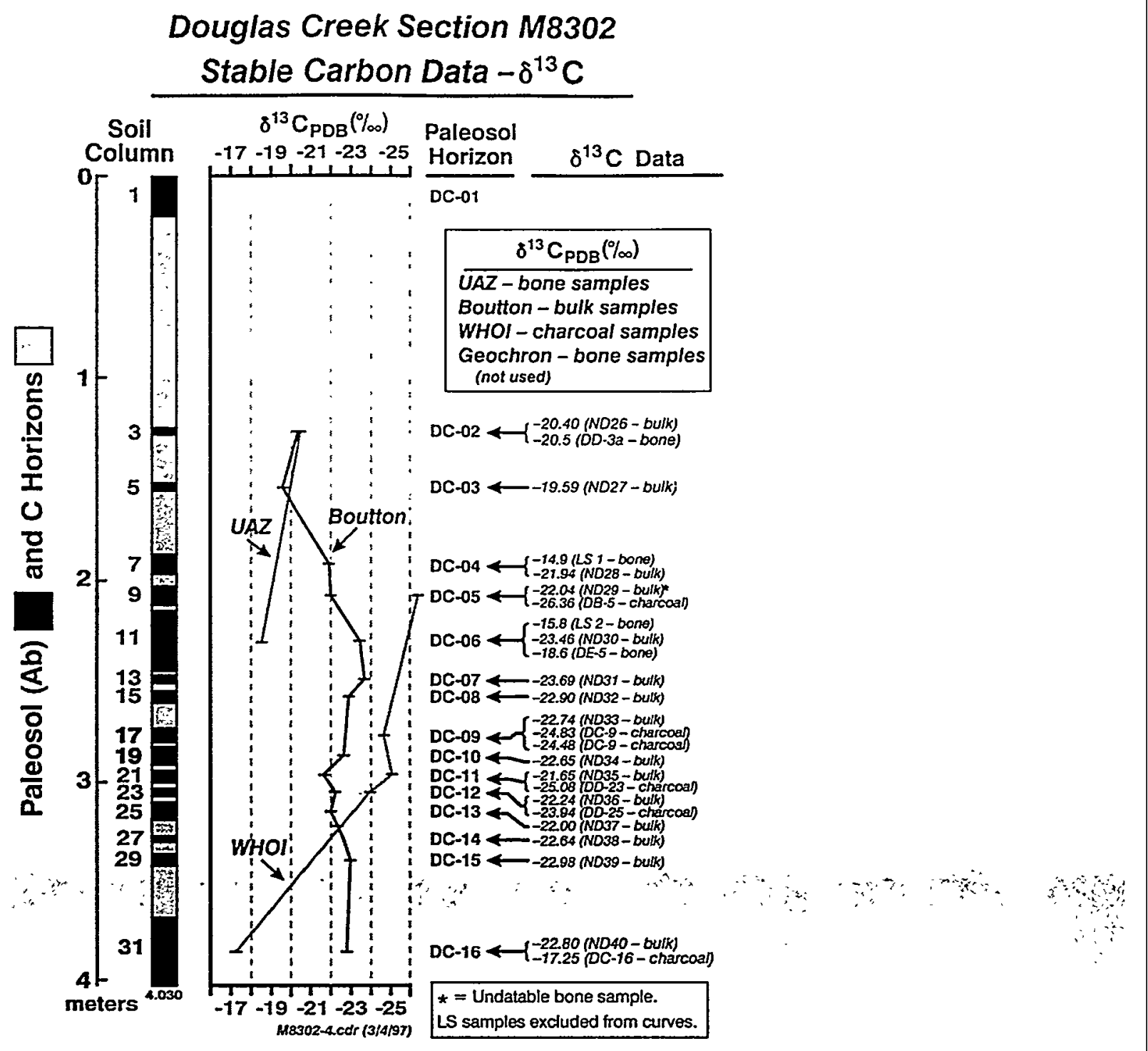

Figure 71. Stable carbon data of Section M8302. Stable carbon values were derived from laboratory analyses by Boutton (written communication, 1996), UAZ (written communication, 1997), and WHOI (written communications, 1996, 1997). The values between these three groups of analyses are not directly comparable, as different processes and fractionation procedures were employed. Boutton's analyses use bulk samples specifically for stable carbon interpretation and are believed to be the most reliable for the purposes of this project, while the UAZ and WHOI samples were analyzed on bone and small charcoal samples to derive radiocarbon dates. All stable carbon values are correlated with Section M8302, including multiple analyses on charcoal or bone from the same sample. The Geochron (e.g., LS-1 and LS-2) stable carbon value was based on a bone sample and differs remarkably from other data. The $\delta 13 \mathrm{C}$ values are plotted as occurring at the midpoint of each paleosol. The Boutton data (Texas A\&M University) are believed to be the most reliable. A decrease in $\mathrm{C}_{3}$ vegetation is indicated by the Boutton curve, which suggests a warming trend toward Unit 5. 


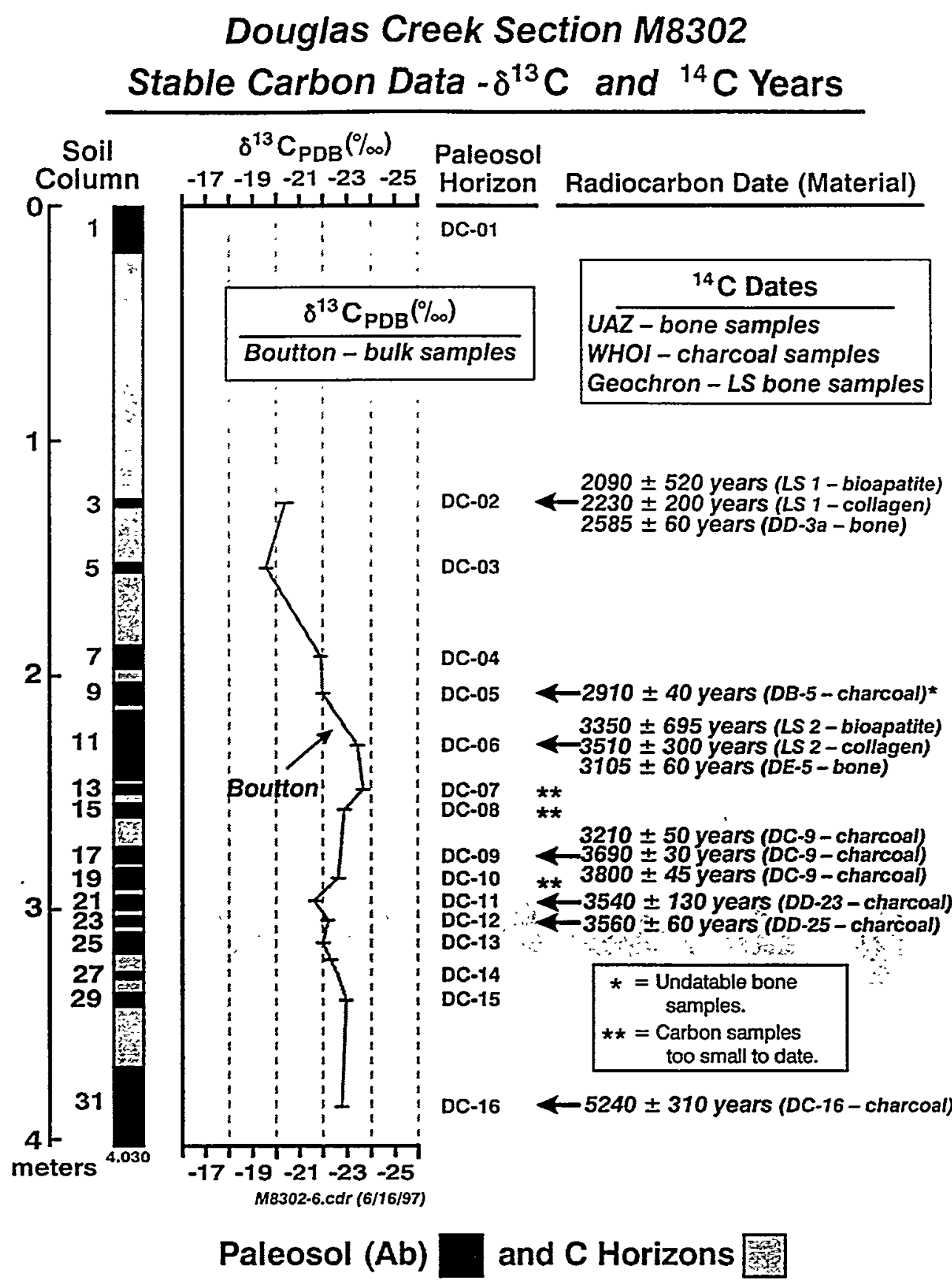

Figure 72. Section M8302 stable carbon values correlated with radiocarbon dates. Stable carbon values were derived as described in the explanation for Figure 31 . The curve shown here is from the analyses by Boutton (written communication, 1996). All radiocarbon dates are correlated with Section M8302 (as in Figure 66), including multiple analyses on charcoal or bone from the same sample. The Geochron (e.g., LS-1) radiocarbon date was based on a bone sample using a non-AMS dating technique (see Radiocarbon Dating section of this report). 


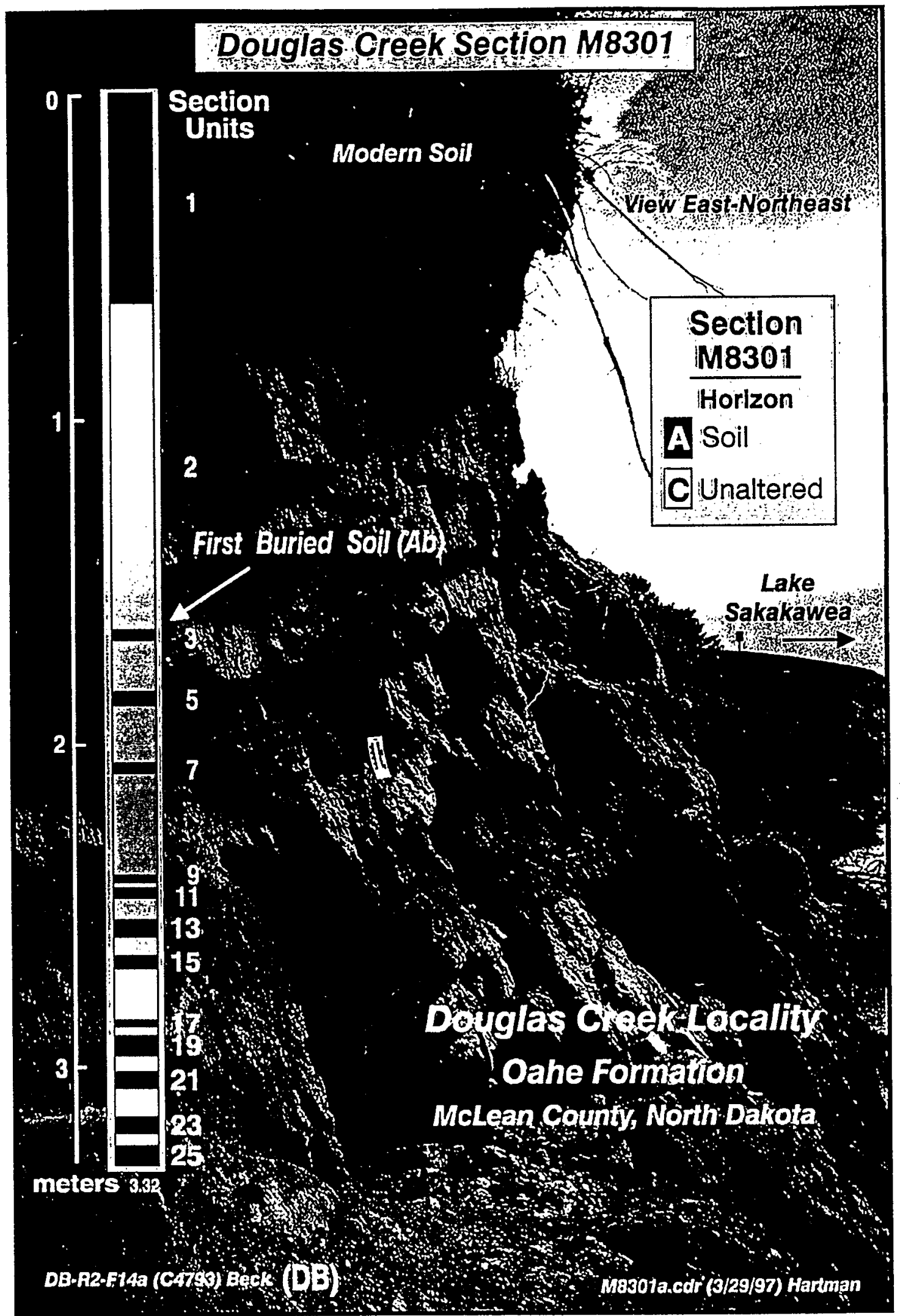

Figure 73. Douglas Creek Locality Section M8301. This section represents the farthest-west sequence of paleosols studied at the Douglas Creek Locality. 


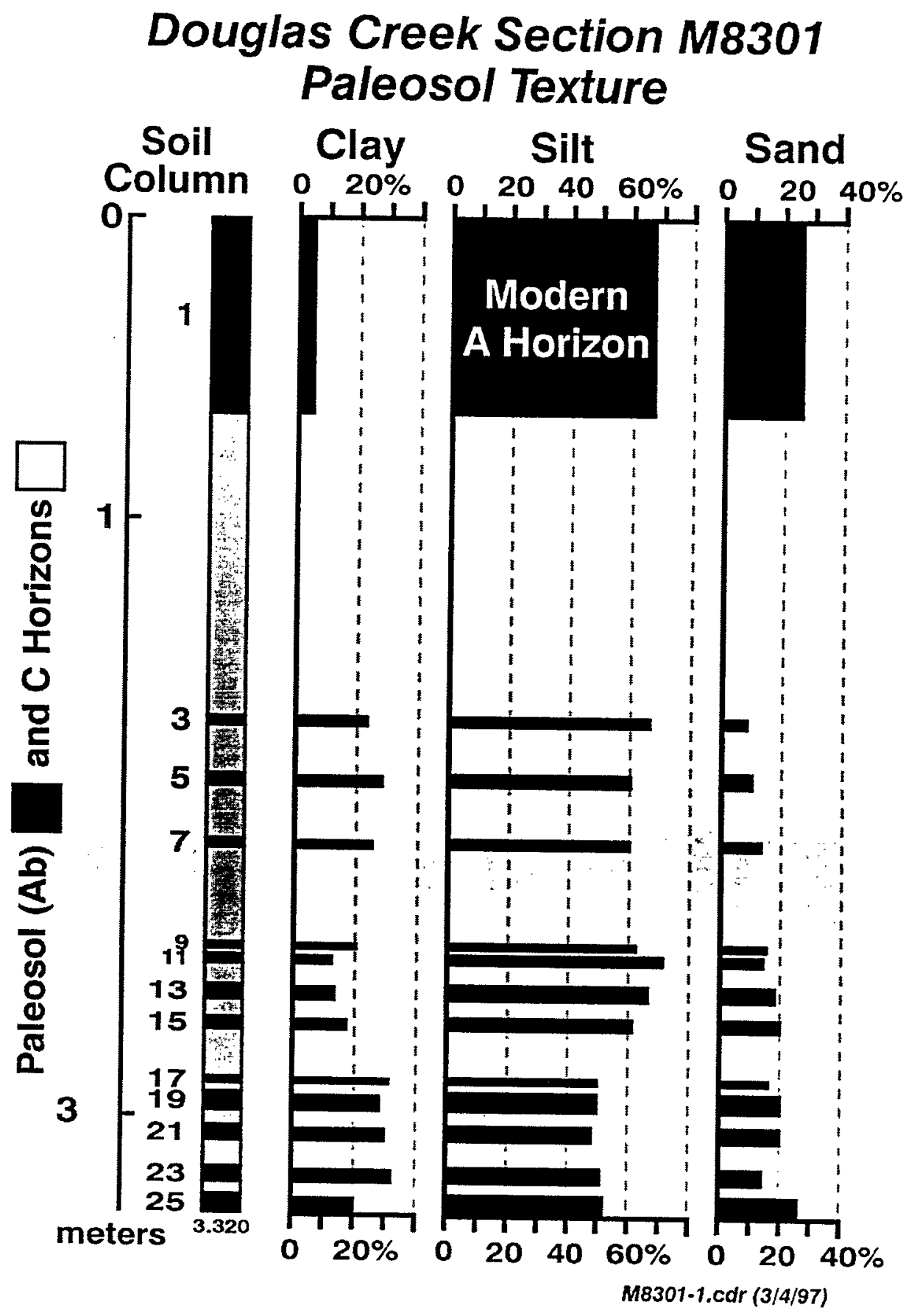

Figure 74. Texture analysis profile of Section M8301. The percentage of clay, silt, and sand is shown for the 12 paleosols and modern soil of Section M8301. Certain trends in grain size are noted in this figure (e.g., overall reduction in the amount of sand), but their significance is uncertain. 


\section{Texture Nomenclature for Section M8301}

\section{Section M8301 Texture}

100

20

80

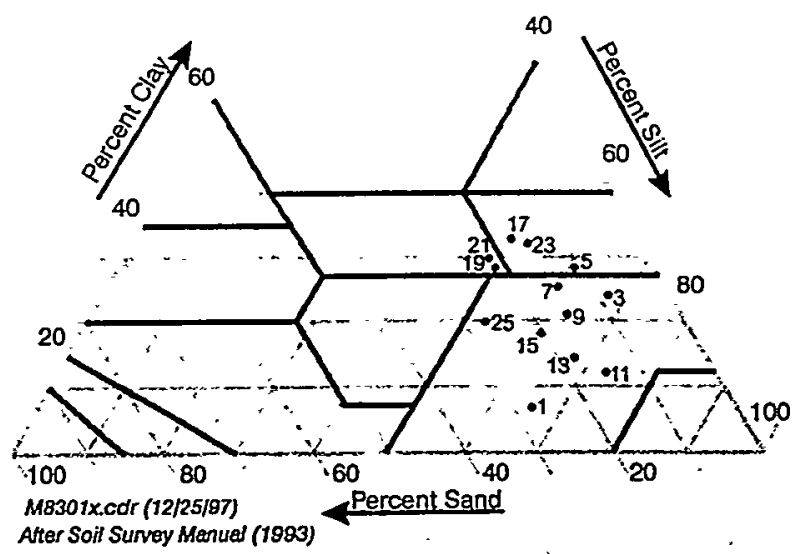

Atter Soil Survey Menuel (1993)

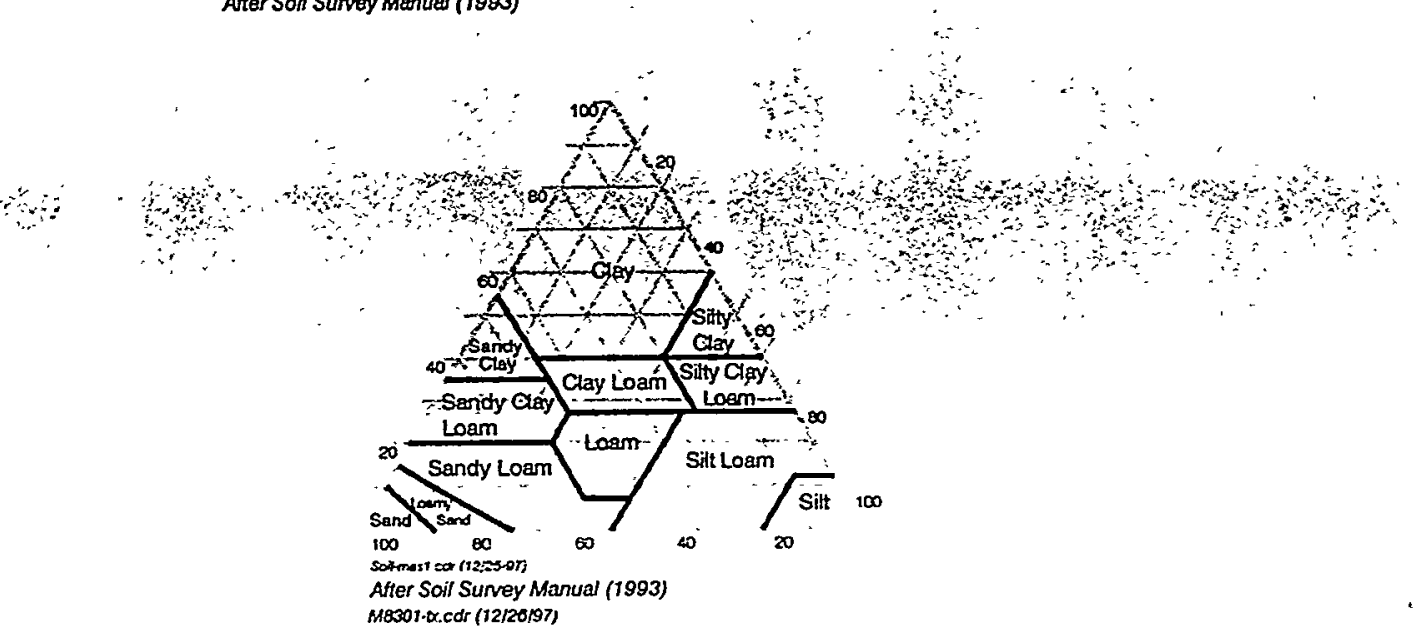

Figure 75. Texture analysis and nomenclature of Section

M8301. Each sediment sample is plotted by unit number onto a diagram of texture nomenclature. All samples are modified loams, representing a high level of silt, some clay, and less sand. 


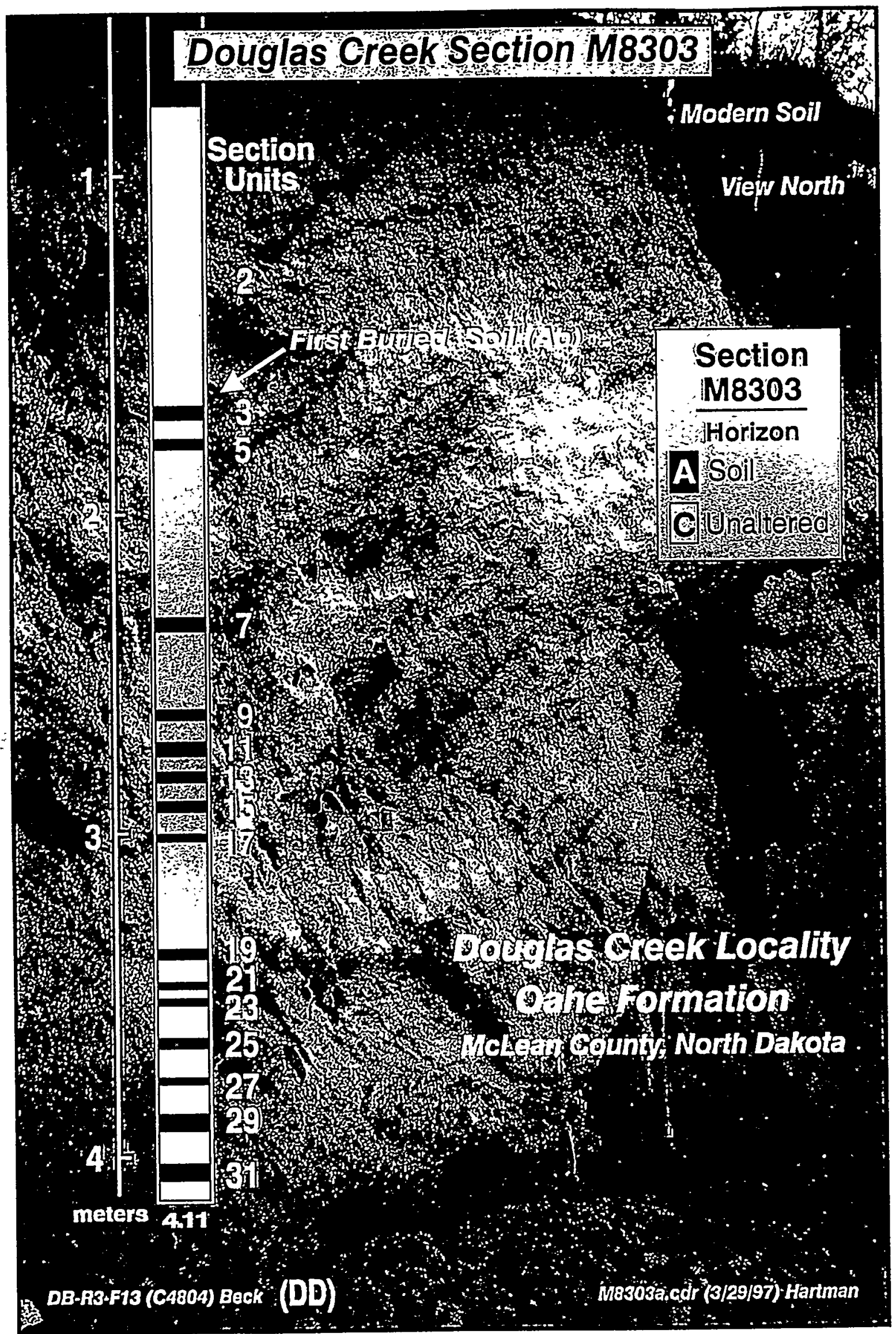

Figure 76. Douglas Creek Locality Section M8303. 


\section{Douglas Creek Section M8303 Paleosol and C Horizon Texture}

Soil

Column

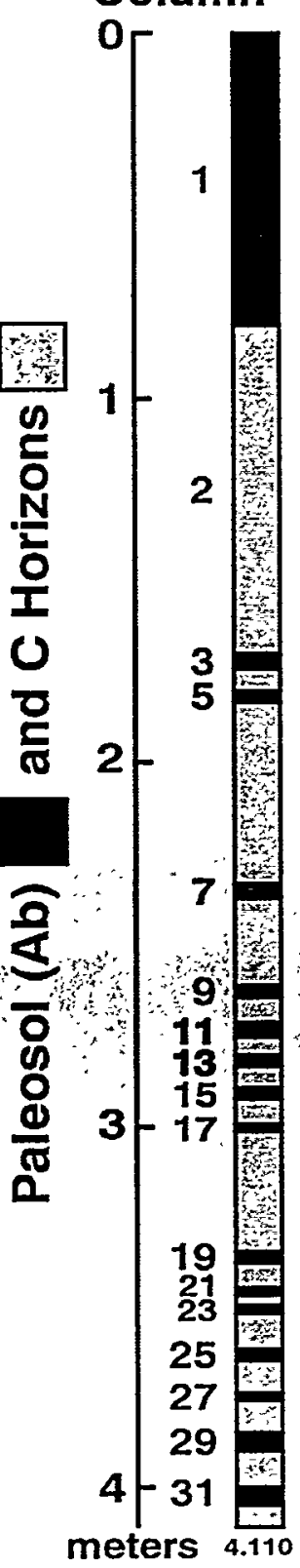

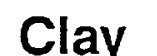

Silt

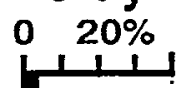

$020 \quad 40 \quad 60 \%$
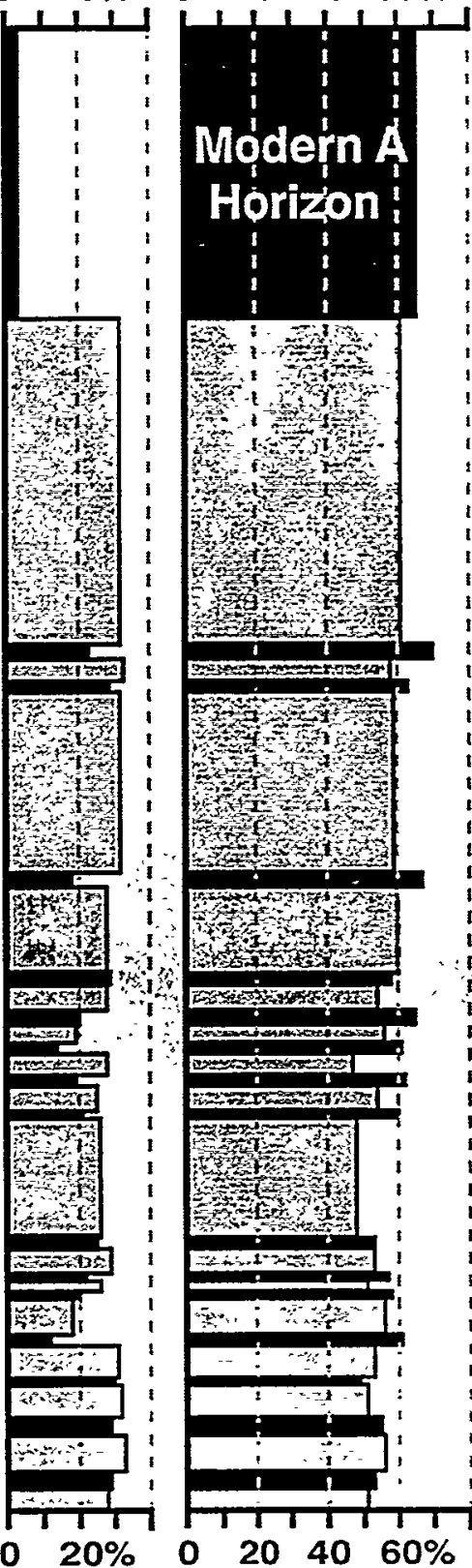

(1)

trit

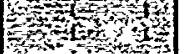

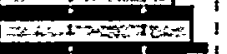

Fin
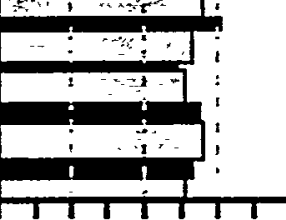

Sand

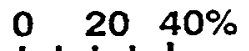

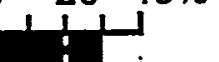

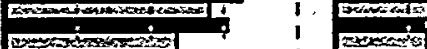

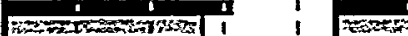

int i 1

ty
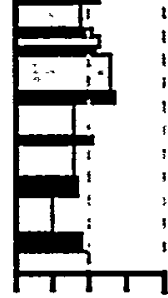

o $2040 \quad 60 \%$ o $20 \quad 40 \%$

M8303-1.cdr (3/2/97)

Figure 77. Texture analysis profile of Section M8303. The

percentage of clay, silt, and sand is shown for the 15 paleosols, $16 \mathrm{C}$ horizons, and modern soil of Section M8303. Certain trends in grain size are noted in this figure (e.g., overall increase in the amount of silt in paleosols), but their significance is uncertain. Also, $\mathrm{C}$ horizons appear consistently to contain less silt than paleosols. 


\section{Texture Nomenclature for Section M8303}

\section{Section M8303 Texture}

100

20

80
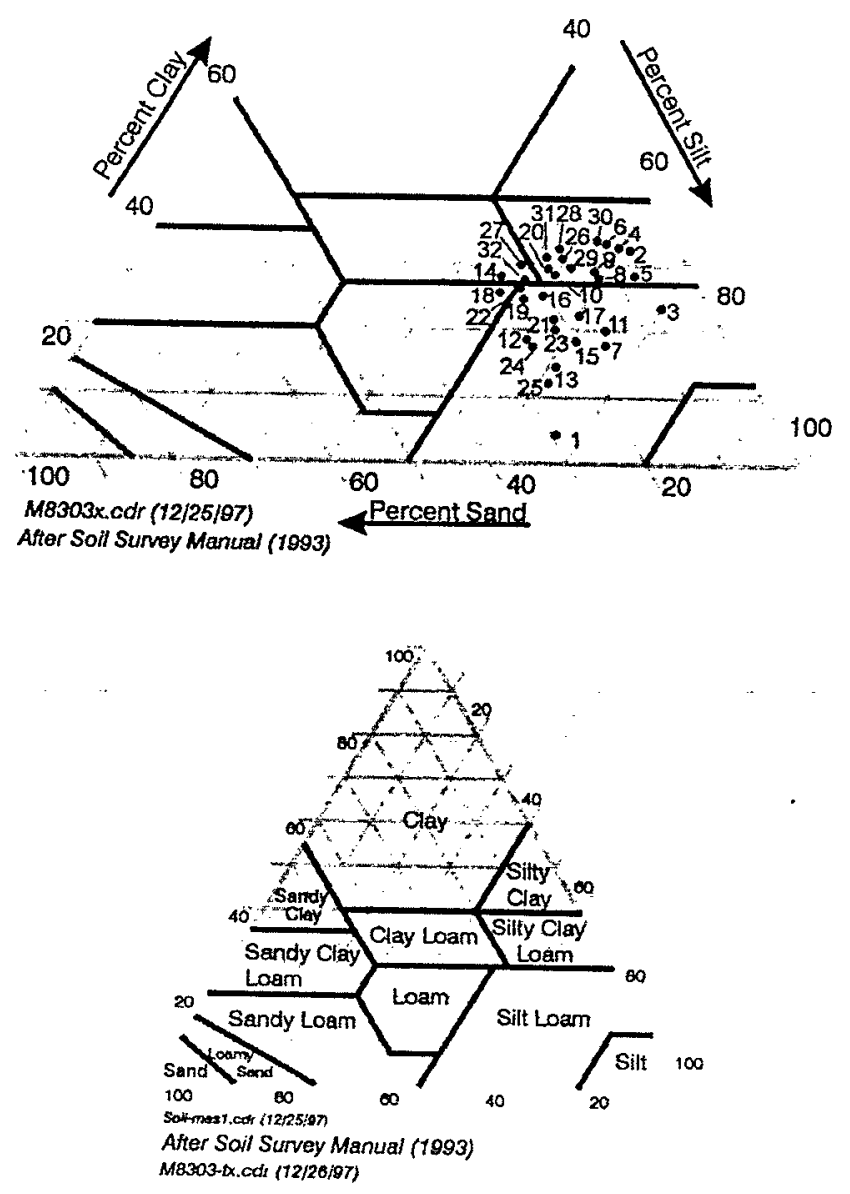

Figure 78. Texture analysis and nomenclature of Section M8303. Each sediment sample is plotted by unit number onto a diagram of texture nomenclature. All samples are modified loams, representing a high level of silt, some clay, and less sand. 


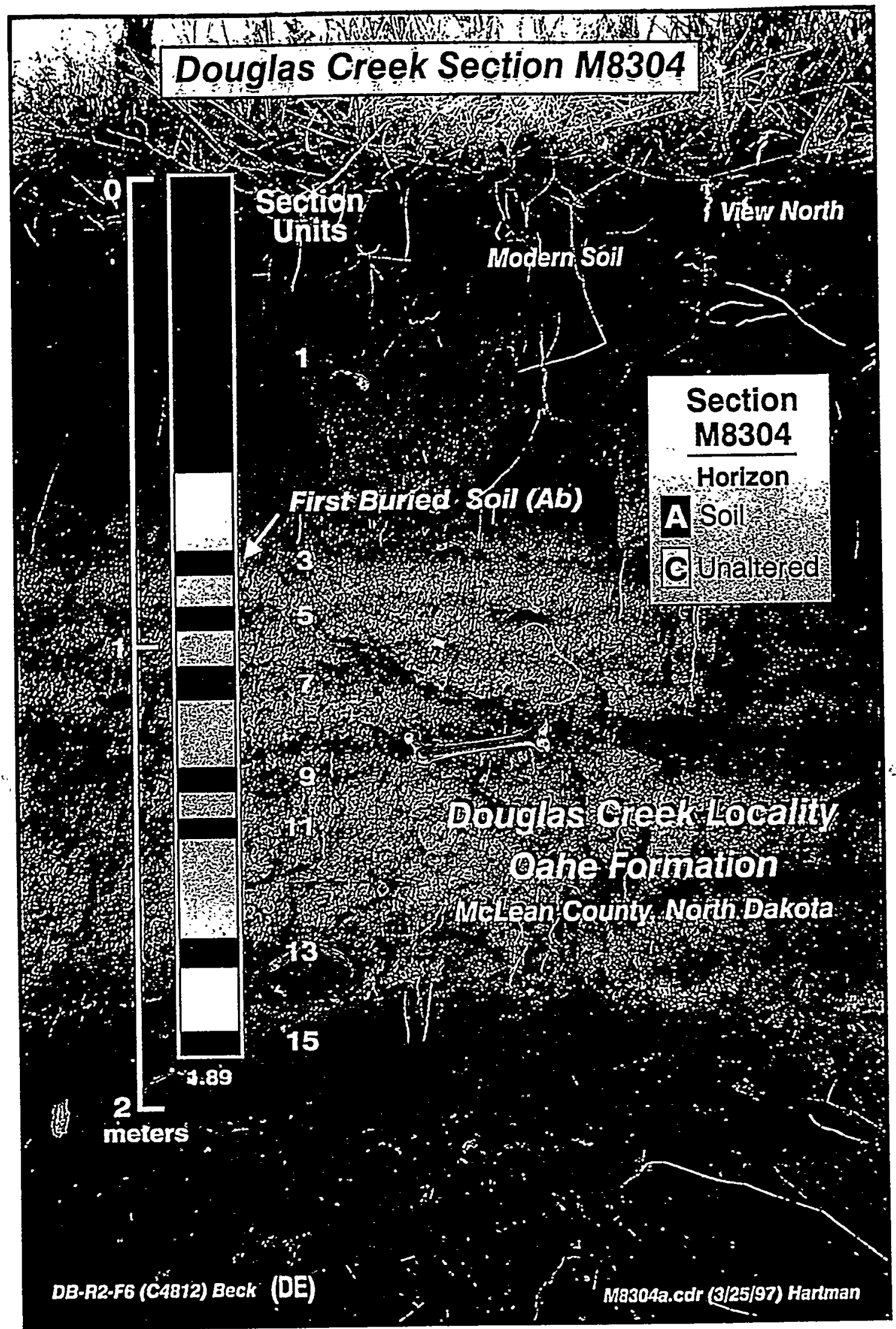

Figure 79. Douglas Creek Locality Section M8304. This section represents the farthest-east sequence of paleosols studied at the Douglas Creek Locality. The stylized bone indicates an important bone horizon. 


\section{Douglas Creek Section M8304 Paleosol Texture}

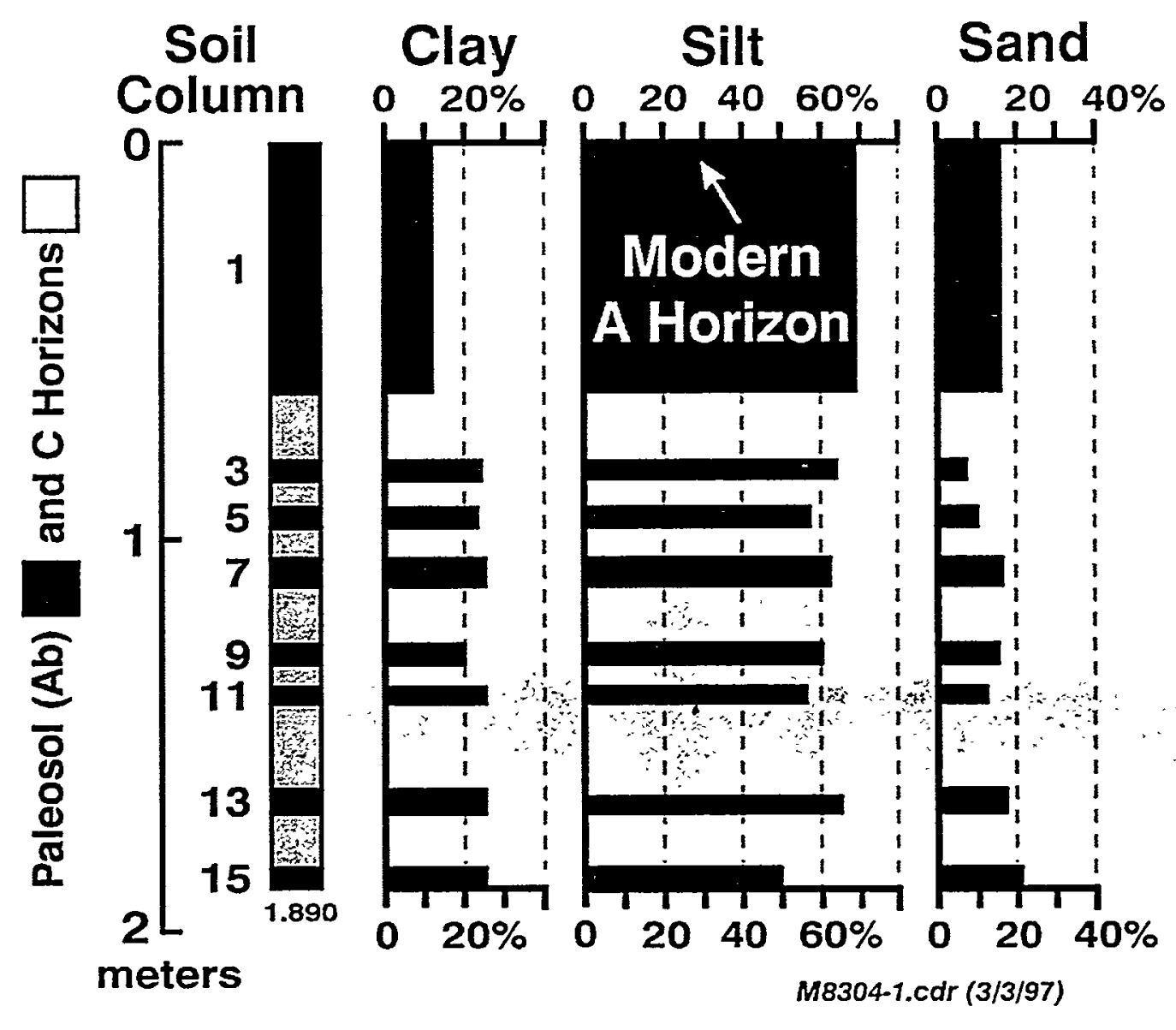

Figure 80. Texture analysis profile of Section M8304. The percentage of clay, silt, and sand is shown for the seven paleosols and modern soil of Section M8304. 


\section{Texture Nomenclature for Section M8304}

\section{Section M8304 Texture}

100

20

80
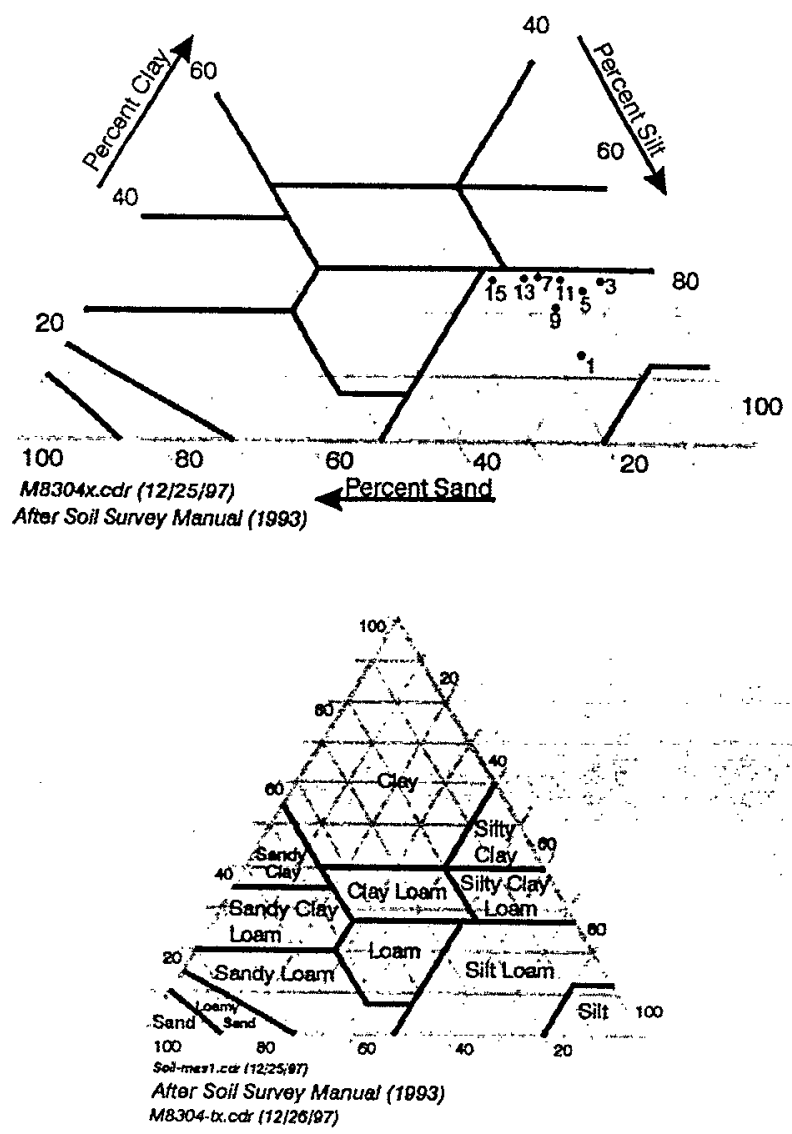

Figure 81. Texture analysis and nomenclature of Section M8304. Each sediment sample is plotted by unit number onto a diagram of texture nomenclature. All samples are silt loams, representing nearly the same amount of silt and clay, with variation in the amount of sand. 


\section{Riverdale Locality Lake Sakakawea-Missouri River}

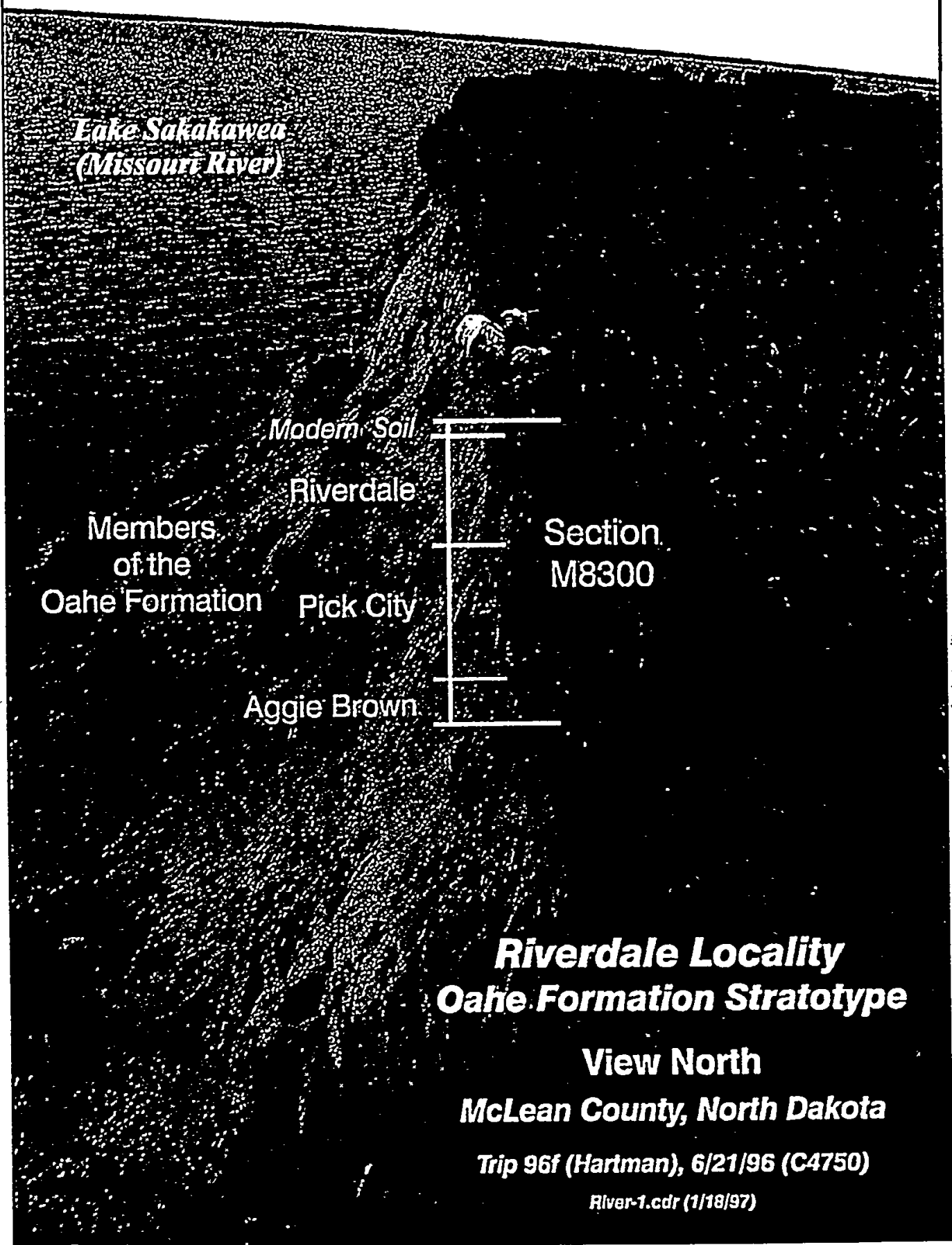

Figure 82. The Riverdale Locality on Lake Sakakawea (Missouri River), McLean County, North Dakota. View of bluff face and upland surface along east edge of lake north of Garrison Dam. No dates are specifically available for the Riverdale Section, but it is known to span the Holocene (see Figures 24 and 83). A bone sample from the Pick City Member (Sample R-7) lacked collagen for dating. The name Riverdale Locality is after the town of Riverdale, adjacent to the dam. 


\section{Riverdale Locality}

Riverdale North Quadrangle, McLean County, North Dakota Wolf Creek State Game Management Area

Sec. 22, T. 147 N., R. 84 W.

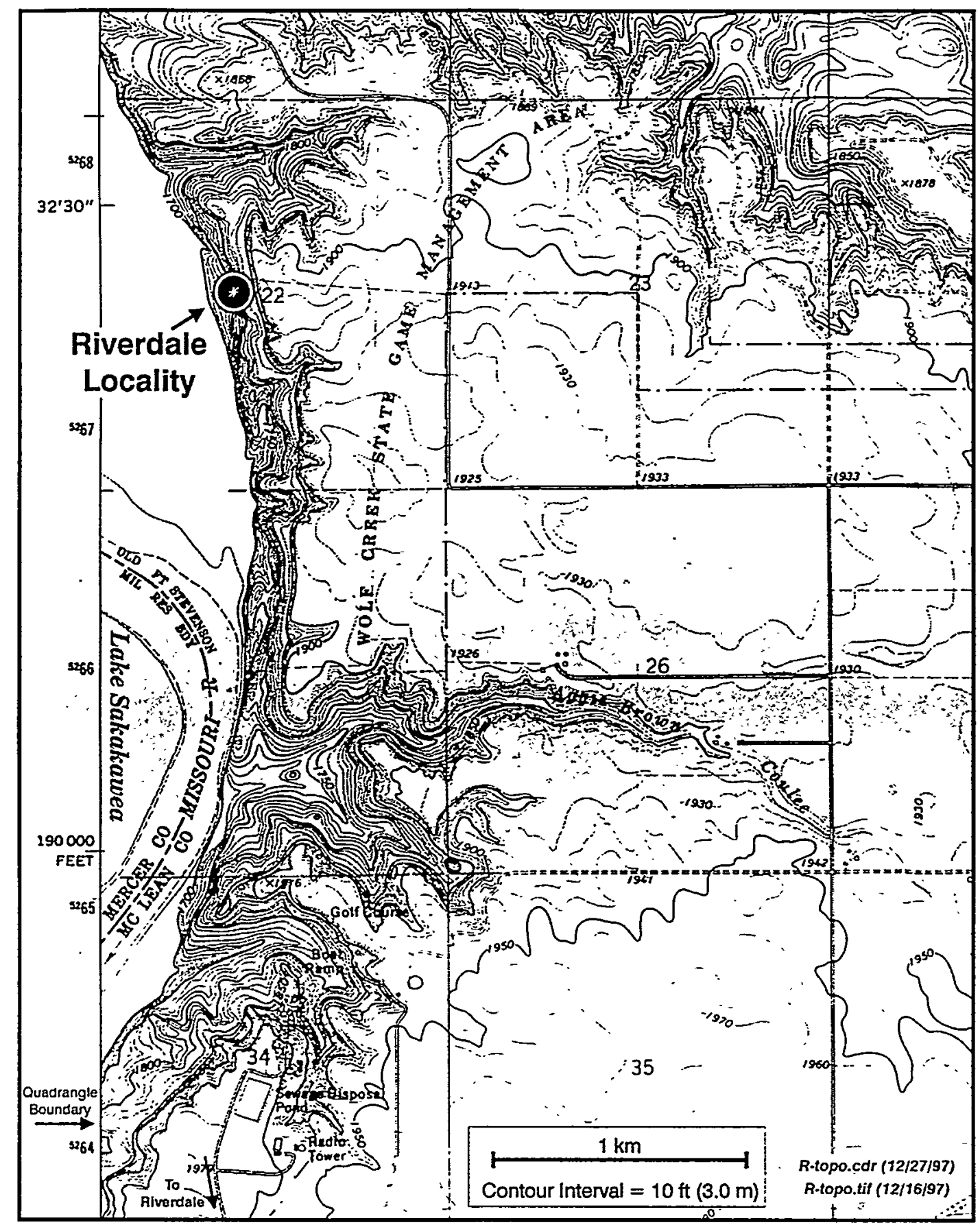

Figure 83. Topographic location map of the Riverdale Locality (Riverdale North Quadrangle). 


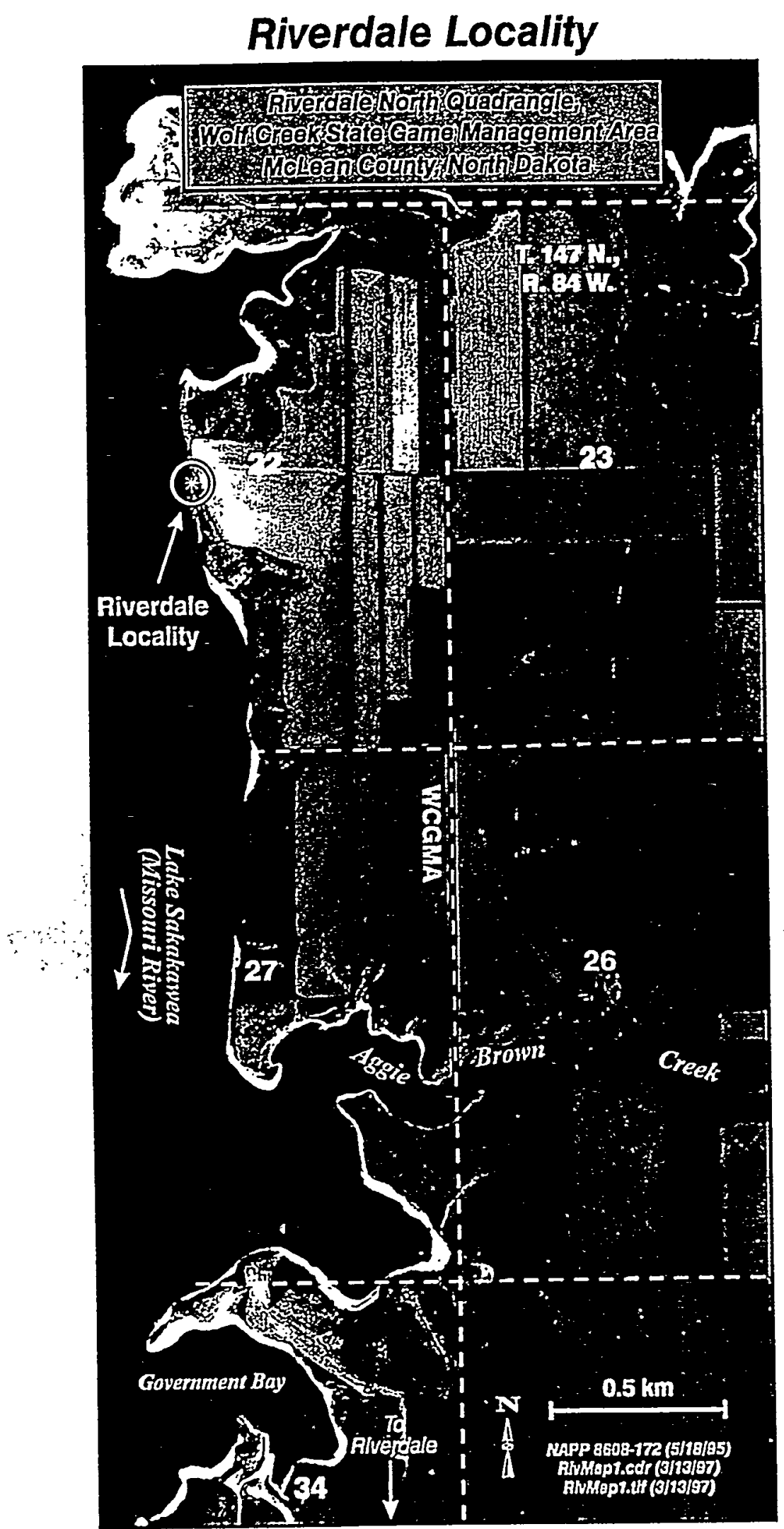

Figure 84. Air photo location map of the Riverdale Locality. The Riverdale Locality is above the eastern shoreline of Lake Sakakawea on steep west-facing exposures. The locality occurs within the North Dakota Wolf Creek Game Management Area (WCGMA). 


\section{Chronometry and Conditions of the Oahe Formation Stratotype}

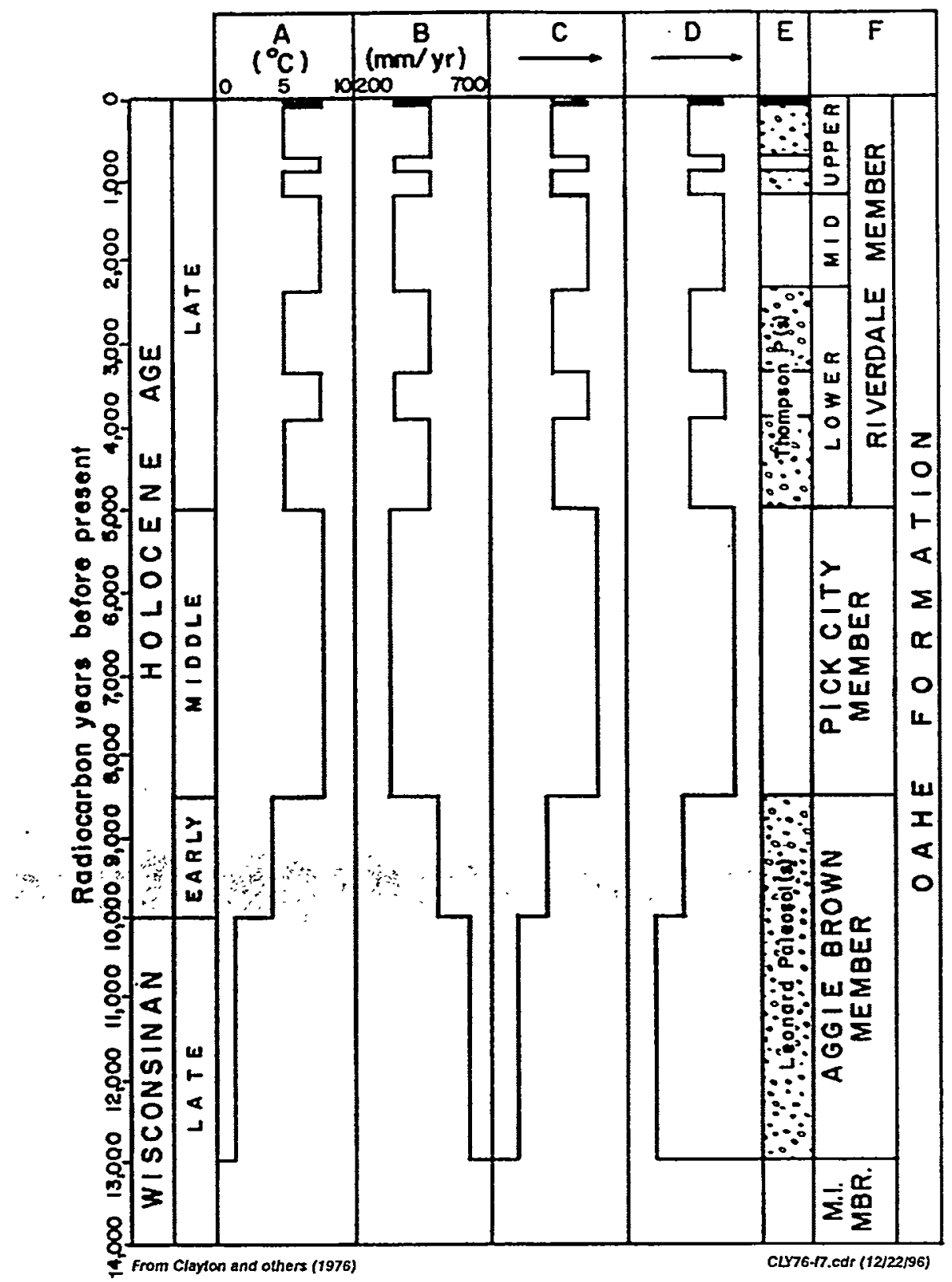

Figure 85. Suggested age relations of the Oahe Formation at its type section, including interpretations of $(A)$ mean annual temperature, (B) precipitation, (C) slopewash erosion on steep slopes, (D) eolian deposition on gentle slopes, and (E) periods of conspicuous soil formation (from Clayton and others, 1976, fig. 7). 


\section{Texture Nomenclature for Section M8300}

\section{Section M8300 Texture}

100

20

80
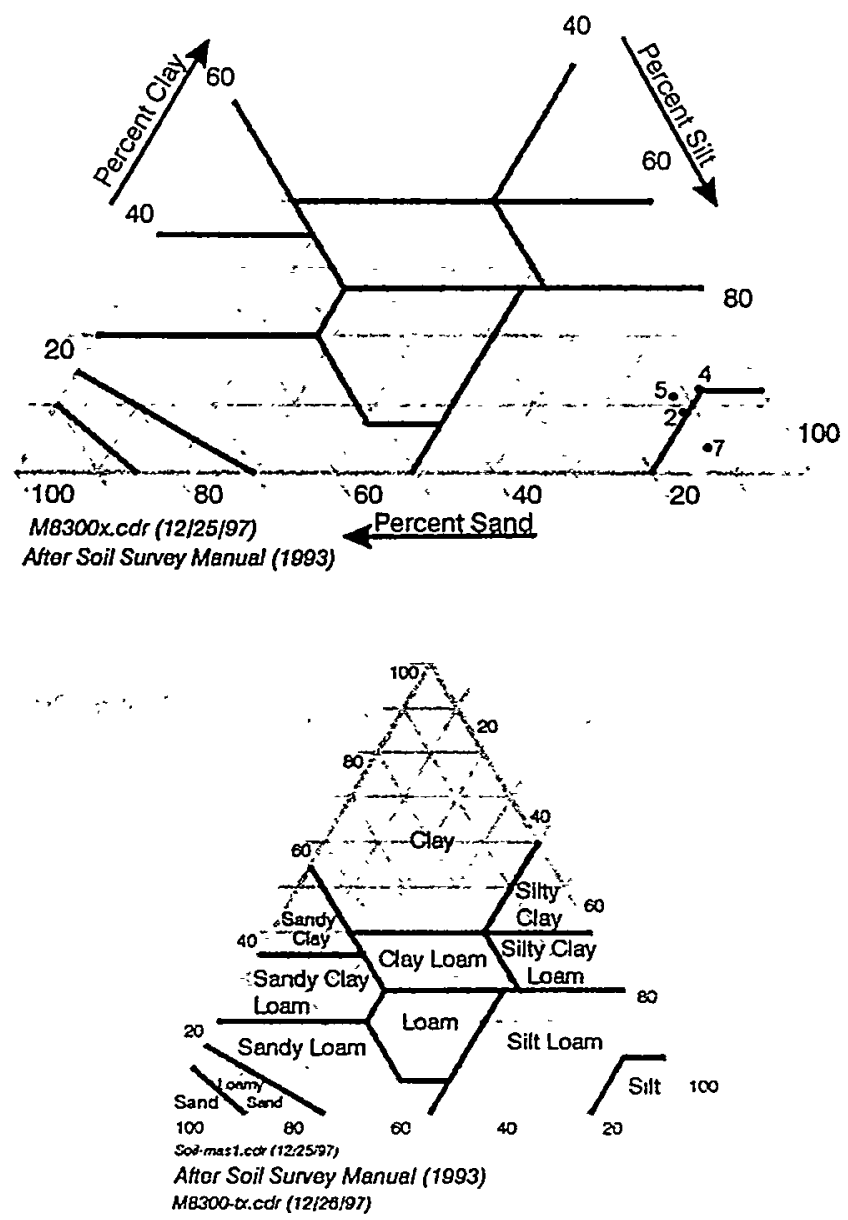

Figure 86. Texture analysis and nomenclature of Section M8300. Each sediment sample is plotted by unit number onto a diagram of texture nomenclature. Samples are silt-rich, with small amounts of clay and sand. 


\section{Riverdale Section M8300 \\ Stable Carbon Data $-\delta^{13} \mathrm{C}$}

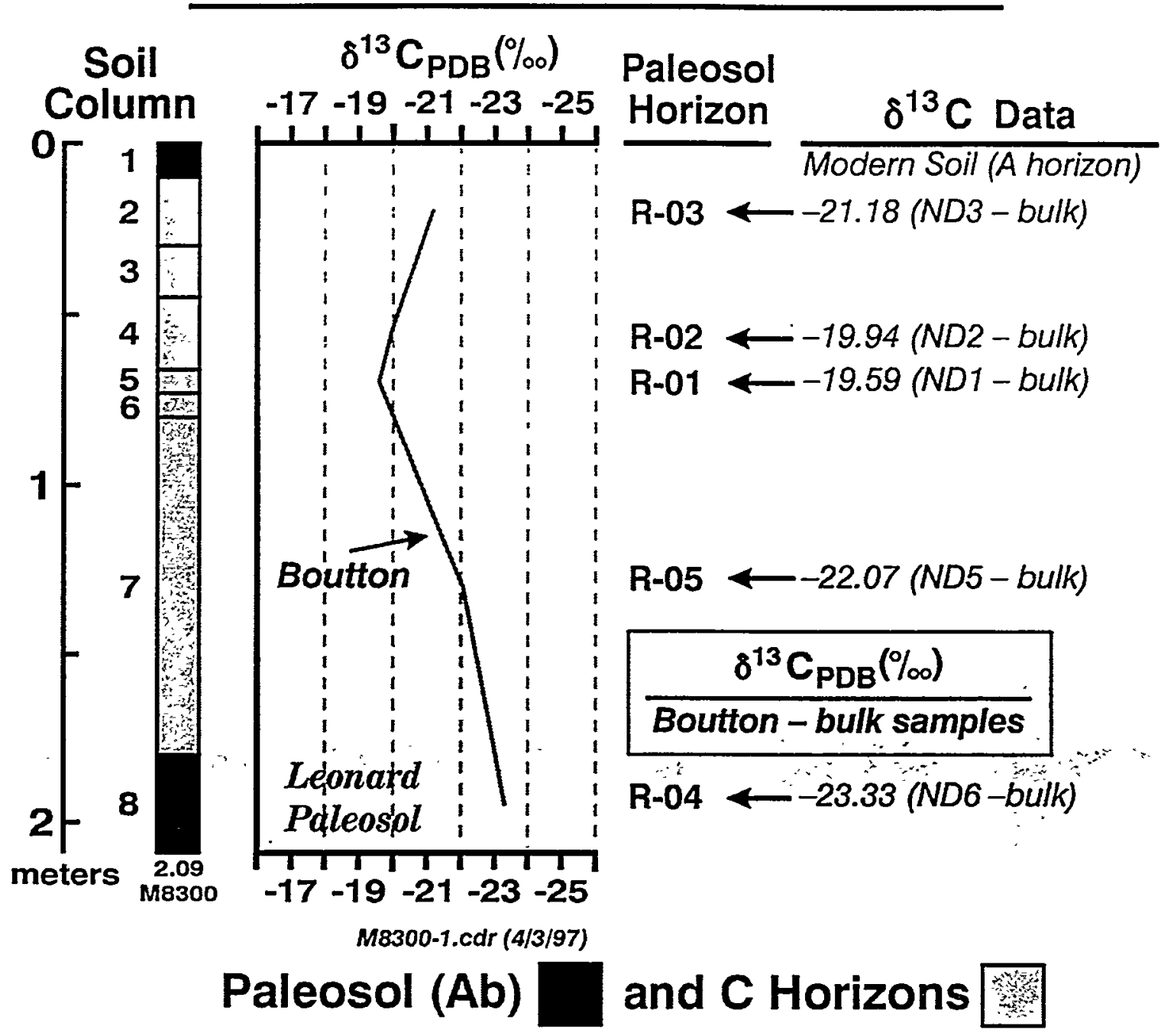

Figure 87. General section and stable carbon curve and data for the Riverdale Locality. A bone sample from the Pick City Member had insufficient collagen to produce a radiocarbon date (UAZ, written communication, 1997). Stable carbon values were derived from laboratory analyses by Boutton (written communication, 1996). 


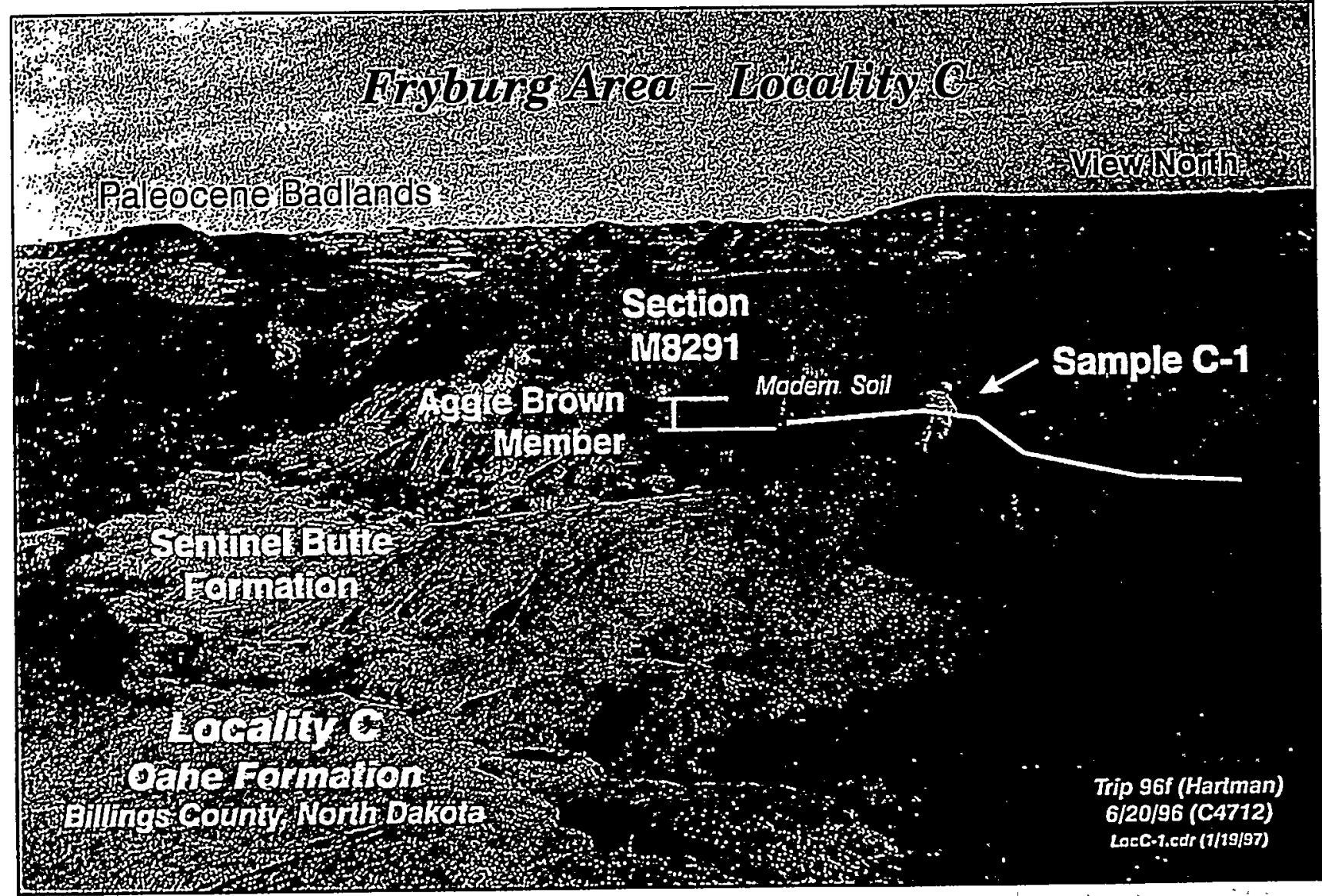

Figure 88. Fryburg area Locality C, Billings County, North Dakota. View along badlands upland surfaces. Locality $C$ represents the Leonard paleosol of the Aggie Brown Member of the Oahe Formation. The Leonard paleosol has been dated as 10,740 \pm 120 years old (see Figure 90). The name Locality C is from Kuehn (1995; see also, 1996). 


\section{Fryburg Area - Locality C \\ Fryburg NE Quadrangle, Billings County, North Dakota \\ Theodore Roosevelt National Park}

Sec. 29, T. 140 N., R. $100 \mathrm{~W}$.



Figure 89. Topographic location map of Locality C (Fryburg NW Quadrangle). Locality C is on the east edge of Theodore Roosevelt National Park, north-northwest of Fryburg in northern Billings County. 


\section{Frybrug Area - Locality C}

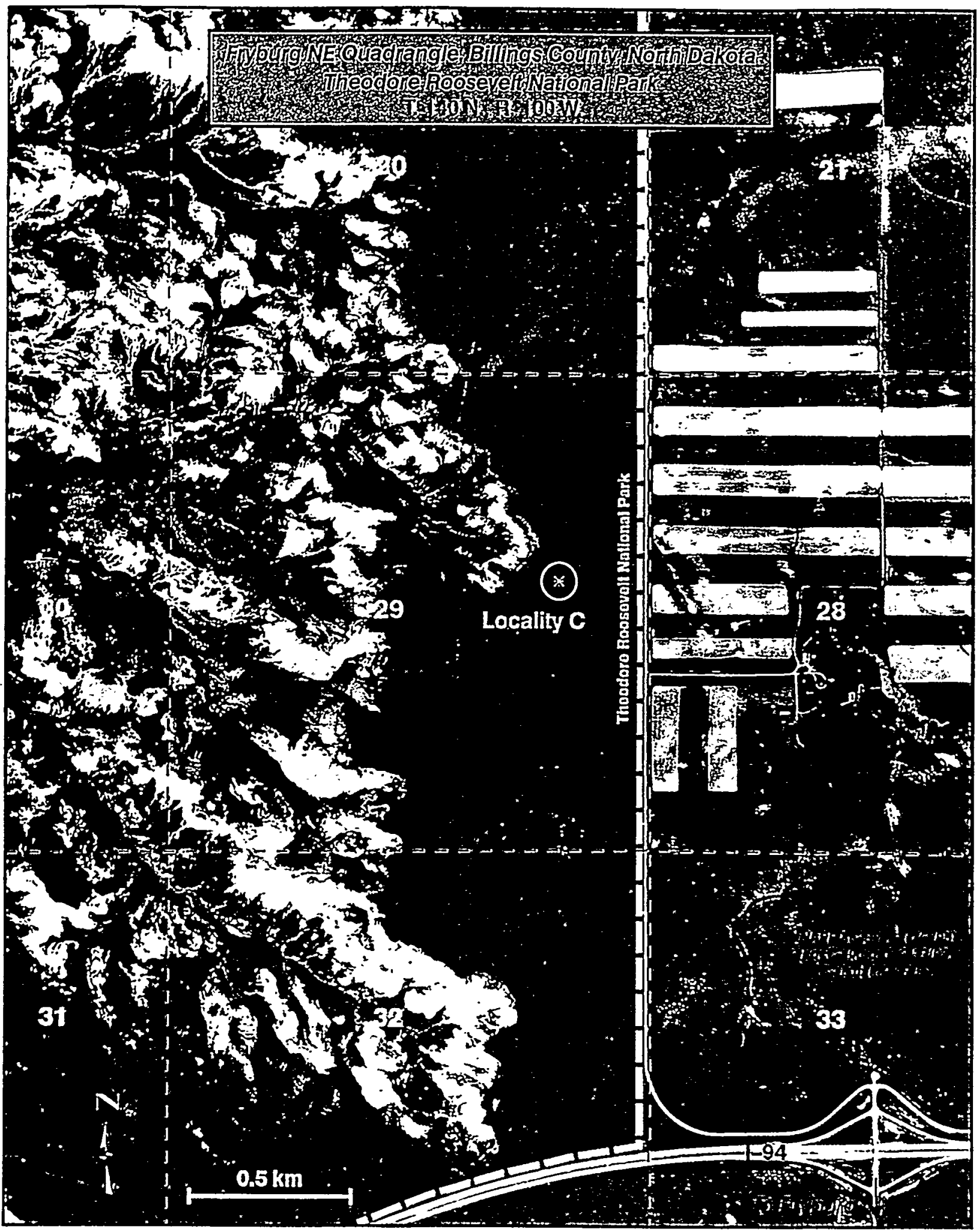

Figure 90. Air photo location map of Locality C. 


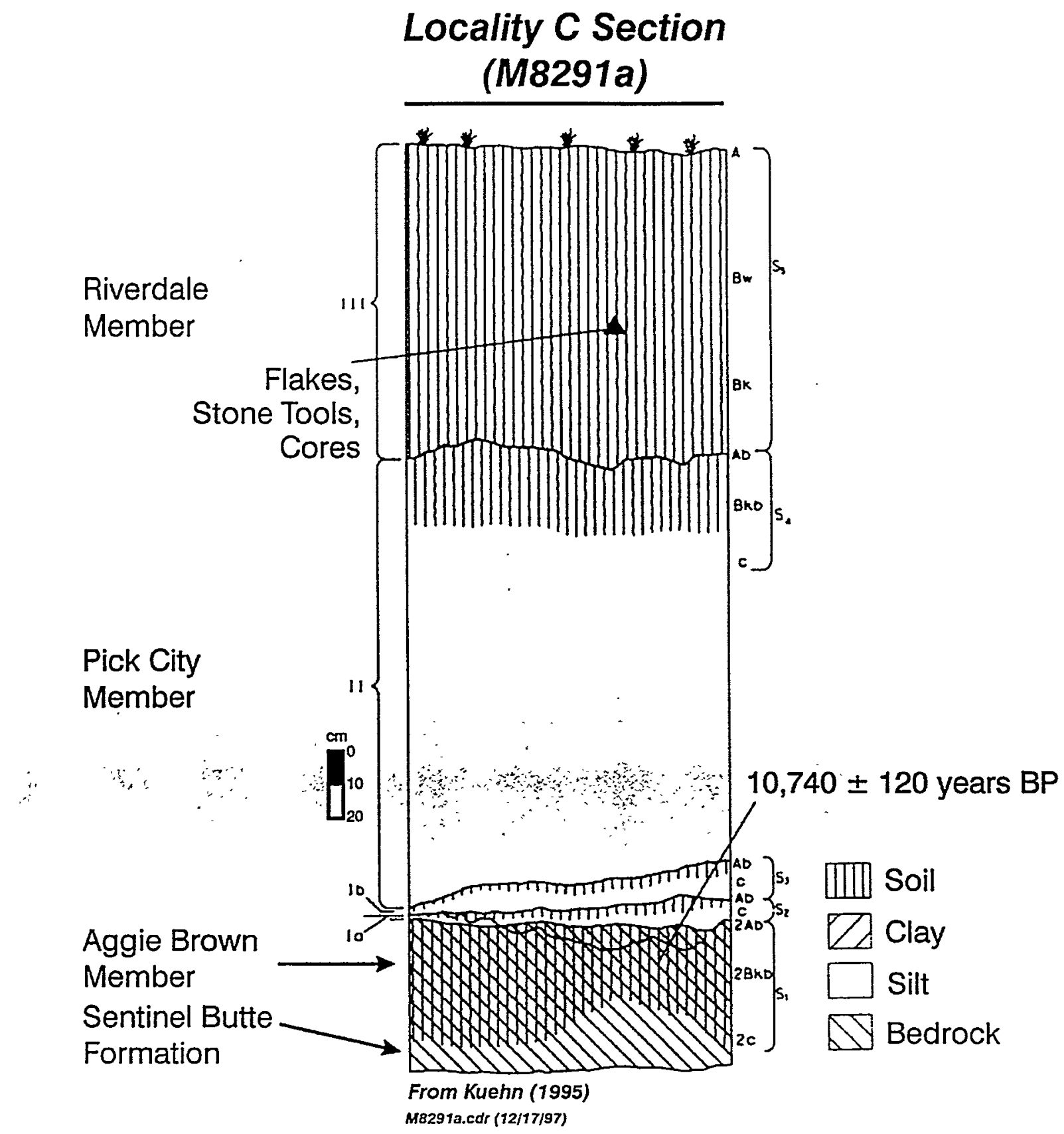

Figure 91. Locality C Section M8291a. This figure illustrates the 2.3-m section described by Kuehn (1995, fig. 18) that includes Sample C-1 from the Leonard Paleosol of the Aggie Brown Member of the Oahe Formation. 
$\cdots, \quad \cdots$ APPENDIX A

THEODORE ROOSEVELT NATIONAL PARK RESEARCH ACTIVITY PERMIT 
292219

May 29, 1996

DI. Joseph H. HaItman

Energy and Enviromental Research Center

University of Norkh Dakota

15 North 23rd Street

Grand Eorks, in 58203

Deas Mr. Hartman,

Xour research activity hat been approved for the selendar year of 1996. Youx Research Activity Permit and park research guidelines are enclosed. Please carty your Research permit while in the park. We would like to take this oppurtumby to remind you that an Investigators Annual Report will be reguested of yau at the end of the calendar year.

The park curator sill seni further information on cateloging any apecimens collected from the park. Also enclosed you whil find the 36. CFR Regulation Part 2 Paragraph 2.5 that requires the cateloging of resequrh specimens.

The park staff lookg forwand to your visit and in gainsing knowledge from you upcoming research results. If you have further guestions, they can be directed to the parks Resource Management Staff Roget Andrasaik or Nancy Keohane.

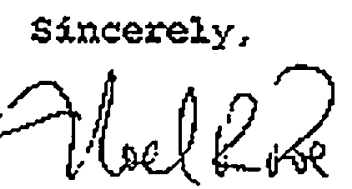

Noel Poe

Superintendent

Bnclosures 
Form 10.741 Research Aotivity Permat

National Park Service, Rocky Mountain Region

Theodore Roosevelt National Park

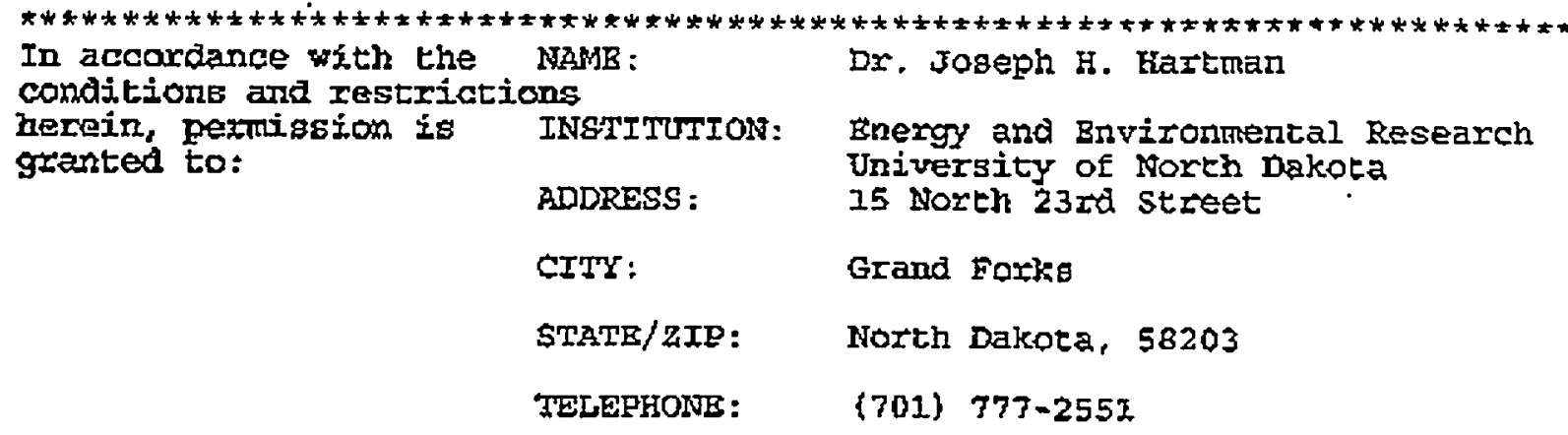

To conduct the following activities in the park; RROJgCT TITLB: Holocene Cyclicity in Pestern North Dakota

DESCRIPTION: Project rill atcempt to interpret climate change by identifying fluctuabiong in alluvial sedimentation. The project fill attempt to validate or negate the thesis that alluvial sedimentation in badlands terrains may record the pattern of climate variation in Iesponse cycles of loper and higher precipitation, which may correlate gith predictable thermal Eluctuations in solar cycles.

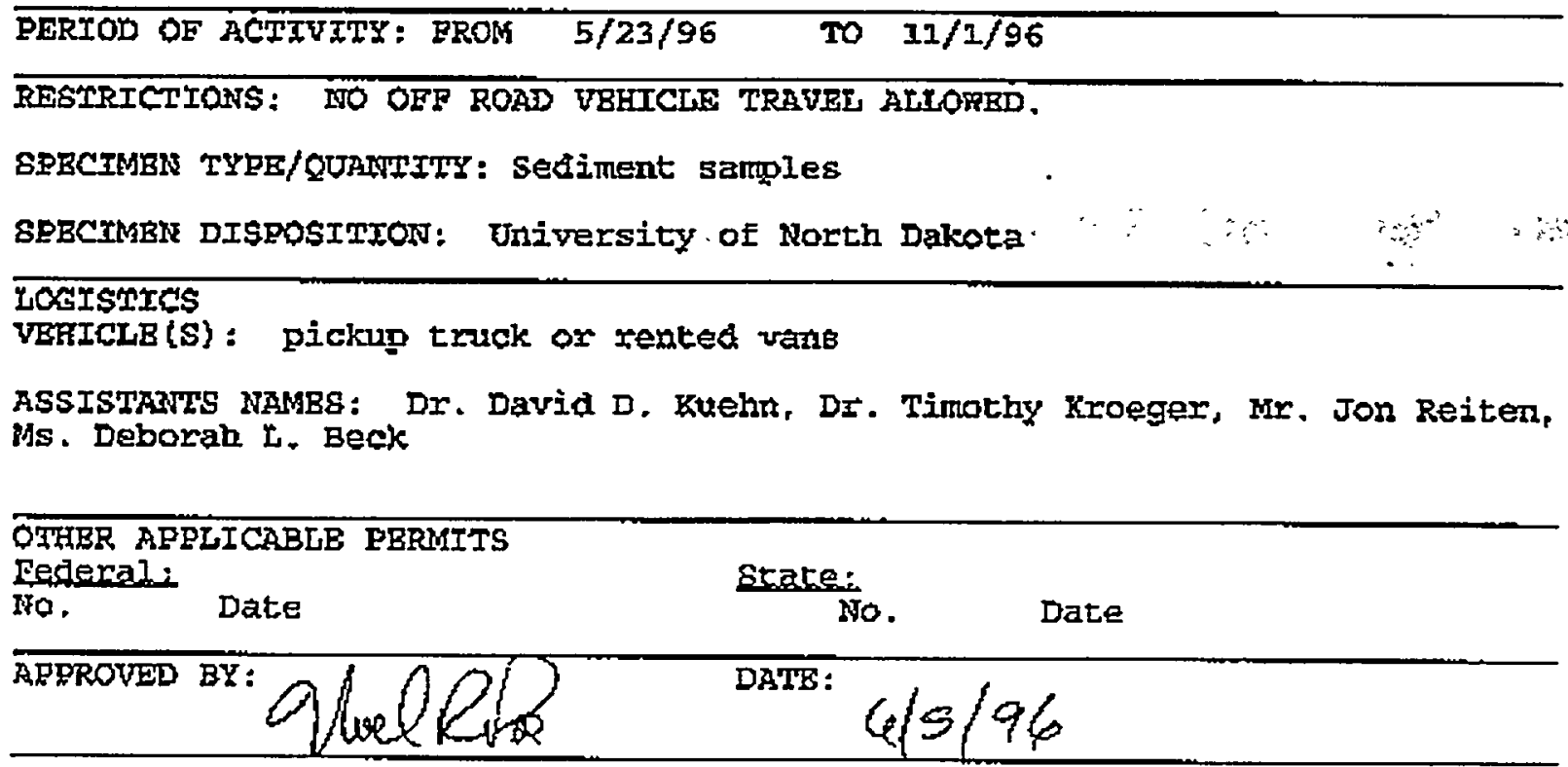

permit must be carried at all times when working within the paxk. See reverse for conditions and reatrictions. PRRMIT BXEIRRS ON DECBMBKR 31, 1996 


\section{APPENDIX B}

\section{PUBLICATIONS}




\title{
THE EVER PRESENT CHARCE OE FLOODING
}

\author{
losph H. Harongn \\ Energy \& Envimanmenlal Reseanch Center, Lniversily of Nord, Dokna

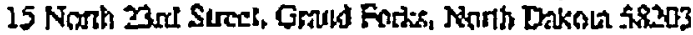

\section{INTRODUCTION}

There is a singuins coskentsus that honding ix.25 incyiluble

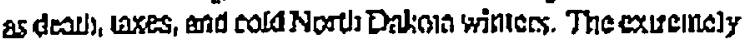
JoW Gmdient of the Rod River ist Use Noth alto the uciuly Mu

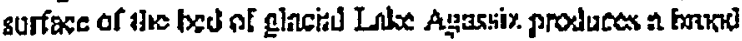

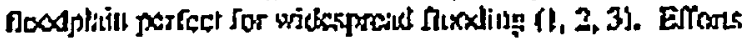

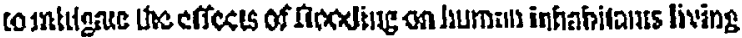
near jises scem, gea]ogicafly spenkithe, lublikely to sucoced in the long tecm silhous a helter wniestanding of tue costs

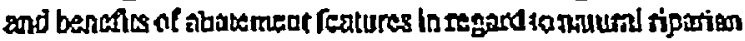
systems and climane cycles. Whonous such dilomation, heavy wibler snows rapid spoing totits, and llast nünstoms are destined co oceur and saise havos with we bsst-loid prolection glans.

As devastatiog as "reeotd" Iothis are to the wel]-being

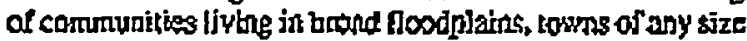
only intrequently pick op and resetuc our of tham's wis. Thus well-thoughtost costingency pluns are roquired to produce

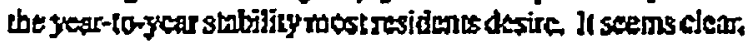
bowevet, that even year-to-year suntegies are ton słant-lem

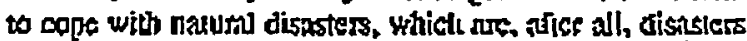

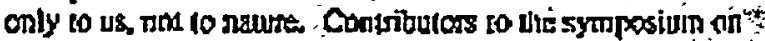
the River Red ftpos of 1997 (4) art sending uncquivnen] messages abour the need for longelerm, generacion-togencration plamning ingluding ntatare-hased responses to datural ocourences.

\section{FLOODING ARD CLIMATE}

An understanding of the pullem of flooding ouer in long

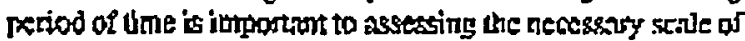
flood abruerient procederts lo procecr the gremes number of citizens prossible. Flood dath since the Lile $18 \mathrm{CK}$ suggnest an loctasing trend toward the groater frequency of lorewe-sede flooding sinee the 1950s (5). Blacernte (I) suggests thit the developstent of establisbed communjuis flong the Red Rix'er oxcuried during relajely drier condlidons. The insermintent ocurrence of moderate Hoxding cvents bas been insulficient 10 dissuade develogers and stlure homeowners from building adjacept to the tive within kmown noodiug comidnrs. TIK almost reguins oceurrence of signiftcan souts silue 1905 has not diuninished expansion of eivies intm Joxd-prone wers.

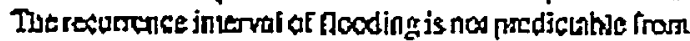

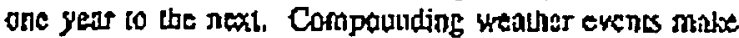

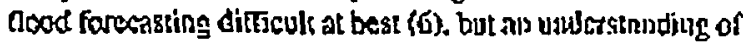

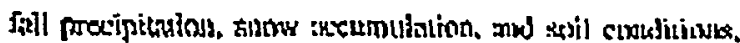

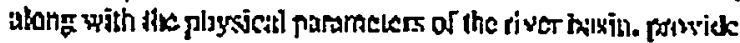
a halsis cor mateling polcrlially cxtrems comlitissns.

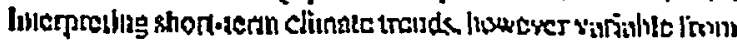
one yeur to the uexl, will comirithute to an kHactitinding at fhaw frequency or palculital Bord sevesily.

Tempernture, precipilation. and atlee hiospliere

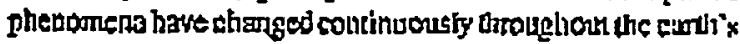
geologic history. An exampie close 10 bome is that Ino aten of Grand Forts-East Grand Fods shas covered by w5 muslt is

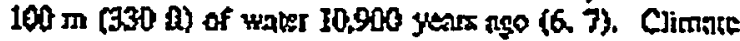
cyeles, trends, or eyerits of yiviogs dumatons and magniludes.

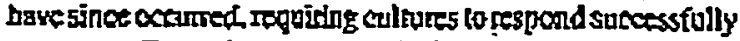
of perish. Eyed since the has glactation, small remperature changes (probably less than $2^{ \pm} \mathrm{Cl}$ bave resulicd ja) nmab]e changes in precipoilation parreros (9) and losations of Inunia)

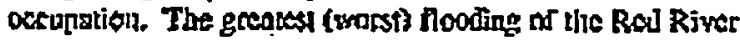

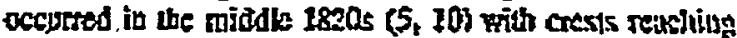
theinhts possibly significanly greates then that altainced by Ibs Rnod of 1997. Ongoing climale studhes (to

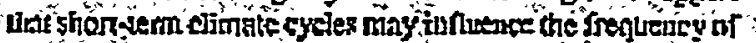
Jood e yenis. Undersianding climate trends or eyeles. alx well

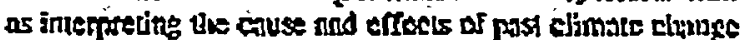

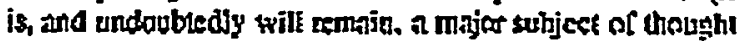
in the scitultite communiny. Recogujizg climate change in

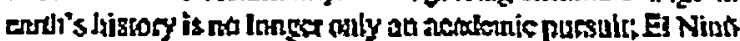
cuents, gtobal waming, ozere yarisbilty, and ute wide raingo of humill intaknes on the eivitarunent and vite veral ane now of fundamental concen to a significant pottim of the propulution.

\section{NATUKAR, FLOOD AMATEABET}

As devastating ftoods will clidllenge the test-consinucred

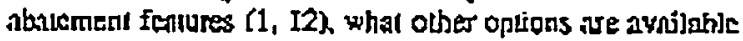
to reduce the tifects of record $n$ torting on a community? The enplitasis of palural abalement methnds is to reduce the amount of water entering the tiver 5y5tem when the flow sete and volume in the main shannal are ilscidy ligh beensse or

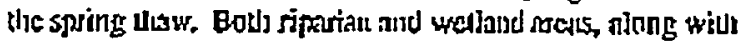

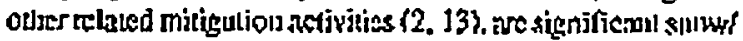
waler catchment asted dat can sulusc crest flow al rriticnl

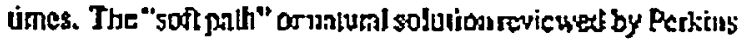
(12) concens the resioration at wellatds but may equitly 
apply to mninterence of ciYcrinc forests: "The faltet the land, the more effectise wethulds tore for Ruxd prosectimi. So. Uhe Red Fiver Yalley and alher paral river yuleyx art

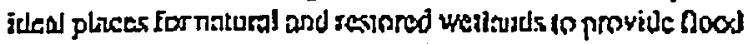
procecion" Thus it would seem logical than a felserationas

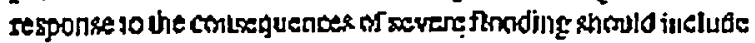

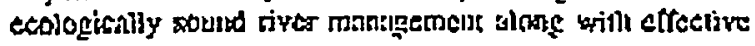
abntemnent plask.

\section{SUMMARY}

The 1997 flood or the Rod Rjuge of the Minrtl wis a wakeup coll. The disastmas ctiecis ols bse cilizens of Gand Forts and Eist Gmats Forks stould um he uladersiaded, but it

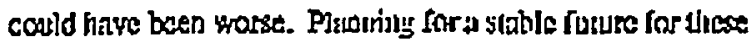
and ndier cowms along the Red Rlwer retuiras allentish to tednil trom ixth the public and profestianal connmunitics. As eximples of commutily involvement and planning the response 10 the devascaling fincds thas occurted ihrough Ropid Ciry in 1972 and to the majatrity of the counises in Atimona in 1993 was to ertnblish palicies based an 10ng-term thiabing. Rapid City estableshed a groen oorridor in the most flood. pron areas. Arizana"s strie and federal respouse was to link agoncies acd vely involyed in footi-nelinted dua gallehist 0

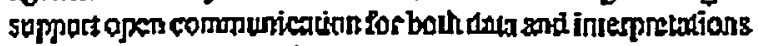
(13). Al lusough the sprits crents assowhed with the severs nooding of the Red Riverare difterenl than in these examples, the resultiag clforts to minimles flooding reffocts through careful planning mav serve as role moxtelc. Judecstunding the record of hoxding through the inkrinctution of historit. dath fof which Grand Forks has as funch as mosi gicinig

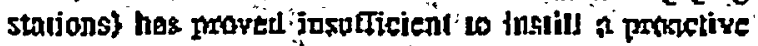

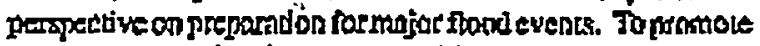
geterer anmeciation for the riwer's history, studies shouth be tonsidered that interprel nooding events preserved in fiolocente sodiments ar the recent past 10 inycstigare the possibility of kng-term cycles or floodug. The specilic jmportance of wellond and ripirinn maimenance and

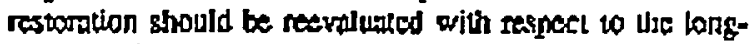
term therits of a compareliensive frolicy on Red River waler tranagement.

\section{REFTERTNES -}

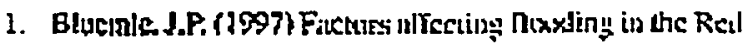

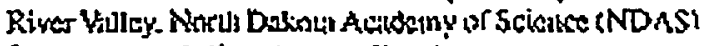
Prtheedings 51 (\$umplenels( 1). llix vislume.

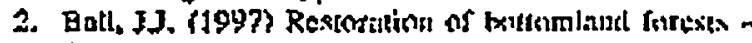
Cluallenpes at1x orpertumilics. NDAS. this inluthe.

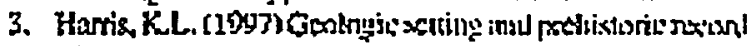
of the Red Rive Valles; NDA5, Uis viduma.

4. Hanmar, J.F. (1997) (Oh.) Syrn pxsitum on the Red Rivel flood of 1997 - Inwly ying xpience in folnse watiendsal thatuennest decisions NOAS, this whlume.

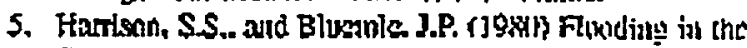
Grand Fatiks-Enst Grand Forkx uten. Nortl Dilktlit

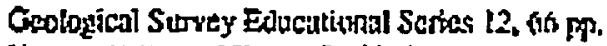

6. Hansen, D.E. and Kumt, J. (1970) The geolngy ar Griul Forks Caunty Nord Dikoka Cenlogical Suryey' Bulletin $53,76 \mathrm{pp}$.

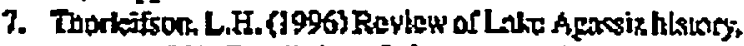
if Tdle, J.T. Thadieftorn, 1.H. Mallle. Gn und Brisbix. W.C. (e-15.3. Sedimentalogy, genmophiolngy. and hisloty

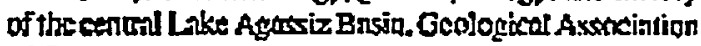
Q1 Cartudn Field Thip Guidebonk pp 5S-84.

8. Osbnrate L.F. Ir (1997) Ap cresview of the Red River valley winter af 1996-1997. MDAS, thls volums.

9. Folland, C.K, Kas], TR, and Yimikow, K.Y.A. (1991) Dbsenalon climsle rarinlions and changen in Honghkn.

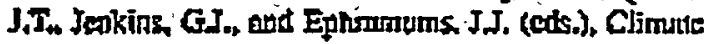
change - The JPCC Scienufie Assessment, Cumbridine

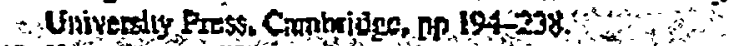

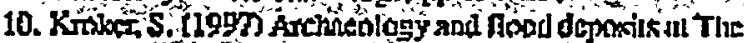

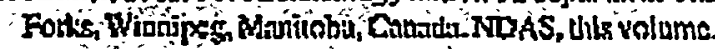

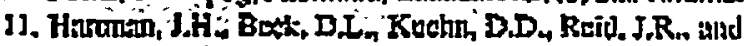

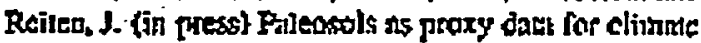
change - Imendeliag Holocene deposits in the brdlatuls

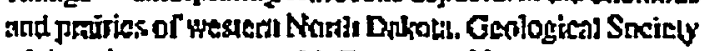
of America Atosiskets with Programs 29(6).

12. Perkits, D. (1997) The hard path atd the sost falh q10 noos protection: NDAS, duis rolume.

13. Mtller. L.G. (1997) Varbal commulutcation. LTM

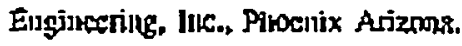


The Gological Society of Anterfo (1997 Annul Meeting, Oct 20-23), Abstracts with Propraras, 4. 29, no. 6, D. A-34.

PALEOSOLS AS PROXY DATA FOR CLIMATE CHANGE - INTERPRETLNO HOLOCENE DEPOSITS IN THE BAOLANDS AND PRAIRIES OF WESTERN NORTH DAKOTA

HLARTKAN, Joseph H. Energy \& Enyironmental Resench Center, Univ, of North Dakofs, Grand Forks, ND 58202-g018, jiturtumenglains.nodak.edtr; BECK, Deborah L., Depc. of Geology \& Geological Engineering, Uniy. of North Dakota, Grand Forks, ND 58202 8358; KUEHN, Dayid D., Dept. of Anhuppology. Texas A\&M Univ., College Station, TX 77843-4352; REW, John R., Dept. of Geology \& Geologieal Engineering, Univ, of North Dakota, Grand Forks, ND 58202-8358, REITEN, Jon, Montans Burean of Mines \& Geology, Momana State Unir., Campus Box 112, Billings, MT S9101.

Late Holocene sediments it badlands tersin of Theodate Roosercle National Park, Bilings County, and in praine settings of Knife River Indian Village Nationd Hittoric Site, Mercer County, and alonts the north shore of Lake Sakakathes (hissouri River), MaLsan County, preserve a record of tumerous paleosols buried by aliavial deposics. Along the headwaters of Krnutson Crock in Roosevelt Fark Ab harizons accur in minor seations ( 4 1.6. 10) with as many as 10 palessols. Although not dated directly, a date ftom a nearty section suggesis formation of the paleosols over the last 1430 yeats (all dates are from AlsS riditeston anslyses). The Krife River Elbee Bluff Loeality onntains 8 Ab horizons in a 2.A-m section, the middle portion of which has five thin, evenily spaced pateosols from about 2000 to 2974 Jears BP. The Iake Sakakawe Douklas Creek Lacality consists of a stacked sunuence of $15 \mathrm{Ab}$ horizons in $22.8-\mathrm{m}$ sestion that can be traced laterally across a small paleorafley. Excluiting the fowerrmost paleosol, the remaining paleosols accut it a 2.2-m sostion spanning about 1580 years from an extimared maxithum of 4165 Jears to 2585 .60 years BP.

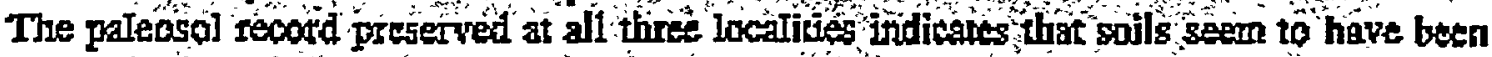

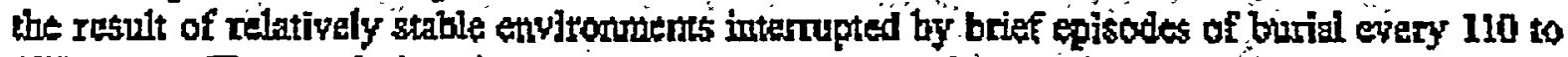
170 years. The regularity of these burrial events may stand as possible proxy indicarors of minor climetic variarion on an otherwise general reoord of climave statilizy. Sable carbon saddies of

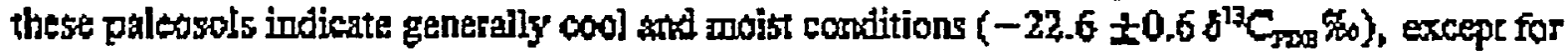
thoge forming about 2585 years $\mathrm{BP}$ (Douglas Crosk) to at least 2165 years BP (Elbee Bluff), during which wamer and thier conditions $\left(-20.0 \pm 0.45^{\text {b }} \mathrm{C}_{\mathrm{EOB}}\right.$ \% 

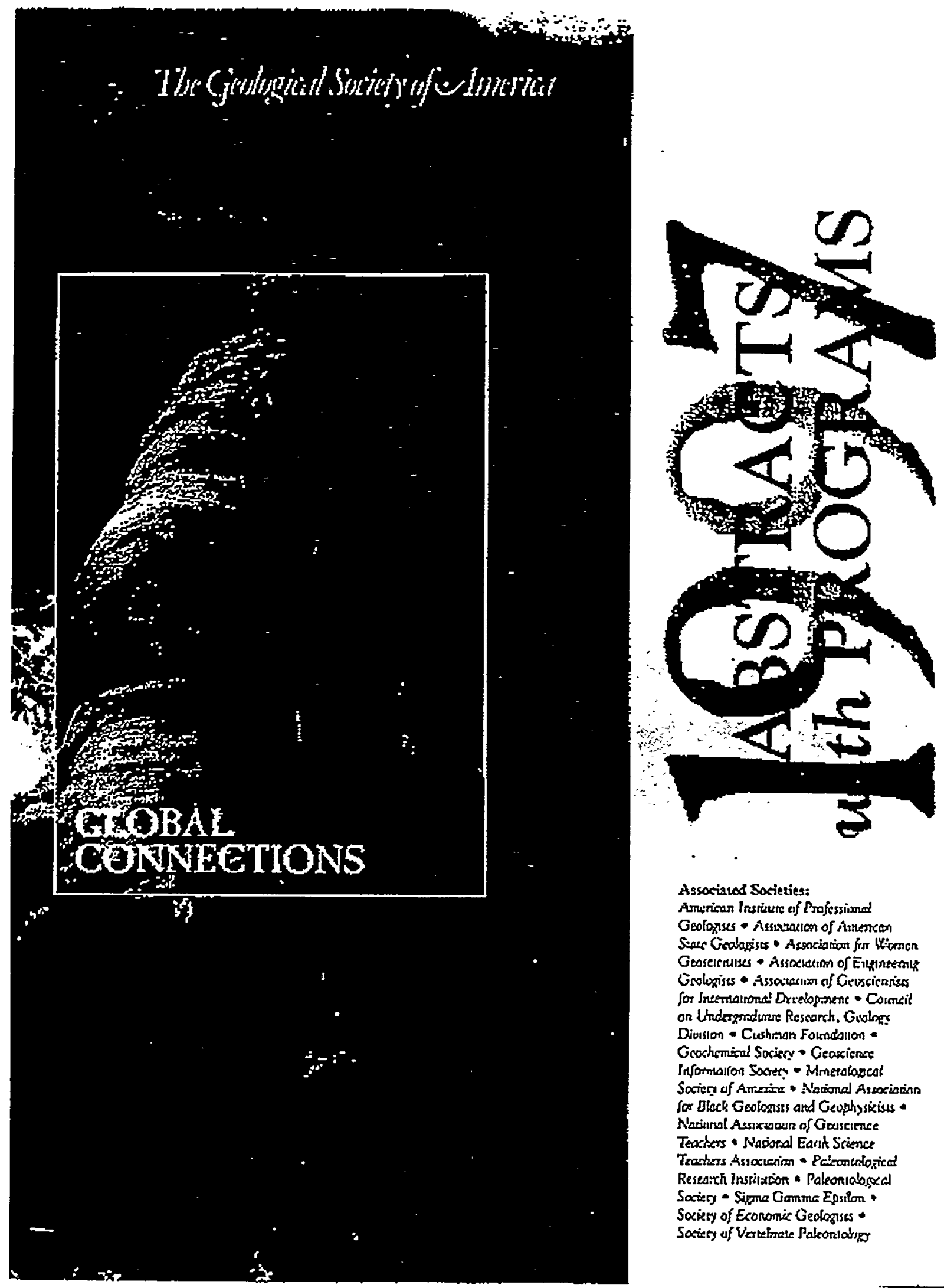

Assoctiaros Soxitties:

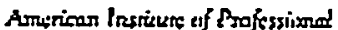
Gsolparses - Aistritanion of Atrencer

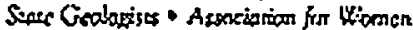

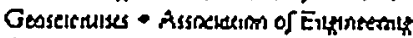

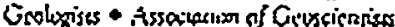

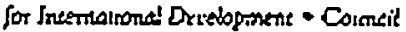
on Lindergondinere Ressarch. Gusloxs Division - Cushras Foumclovion Gorhomizal Soriery - Geaxicrons

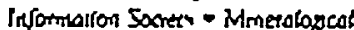

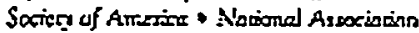
for block Geolozisss arod Geuphysizins Naciural Aussxeverr of Gouscimce Texchers + Napioral Earit Sciencet Trarters Associanion - Peleconeriogical Resesirt instiaxions " Paleoriologscal Socieg - Sipne Gamme Epsitom. Sociny of Exonomir Gedogises Society of Vertinate Paleoniats 


\section{Proceedings of the \\ NORTH DAKOTA Academy of Science}

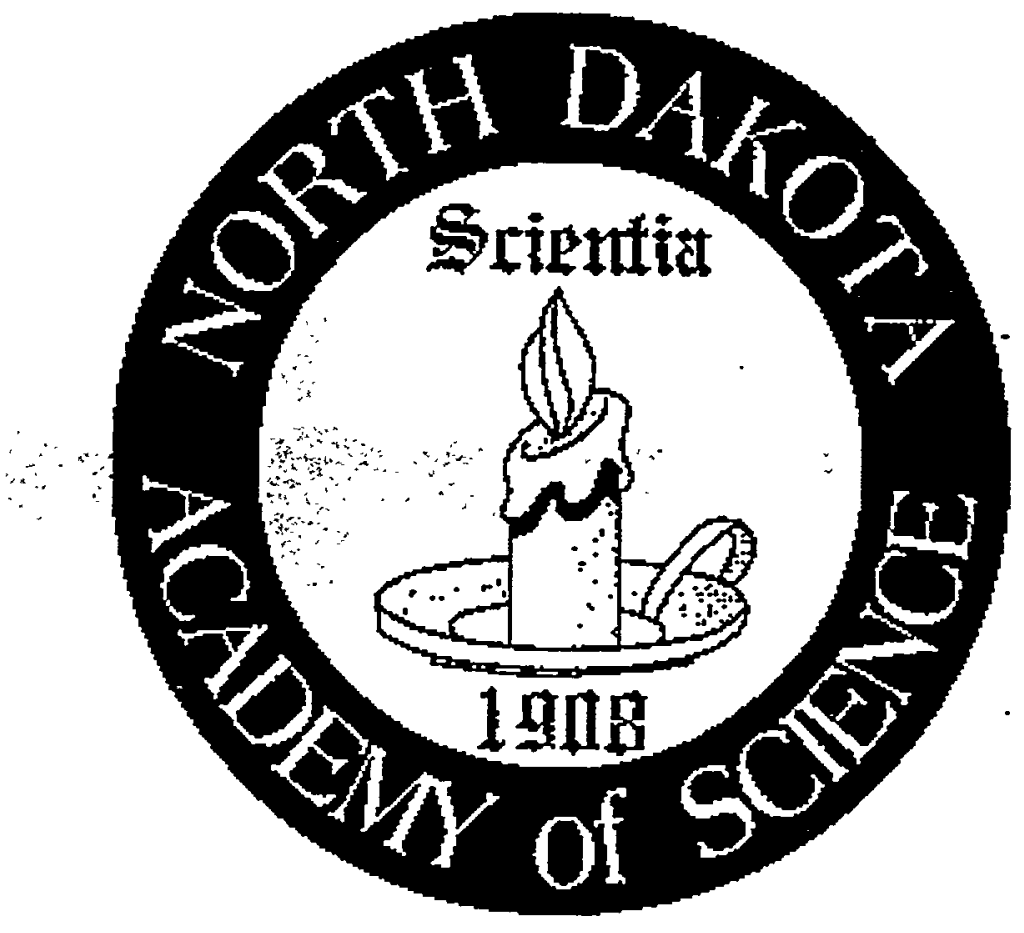

\section{9th Annual Meeting}

April 1997

Volume 51 


\title{
PAIEOSOLS AS PROXY CLMMATTC CAANGE INDICATORS IN CENTRAL NORTH DAKOTA
}

\author{
Deborath L. Bedk"1 and Joseph H. Hartmann" \\ 1Depnutment of Geology and Geological Engineering, Univertity of Narth Dakota, Grand Forss, ND $58202-8358$ \\ Energy \& Enyinonmenthl Resenteh Centet, Utriwersity to North Dakoln, Grond Fodis, ND 58202-9018
}

The utility of paledsals as pileocliznale indicators las been recognized by many sudies, including

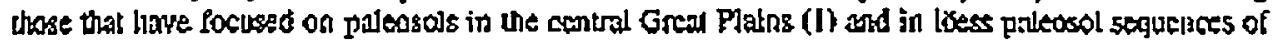

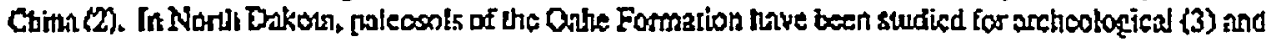

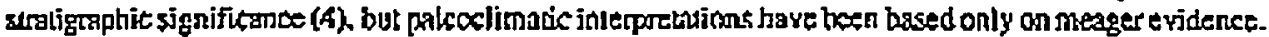

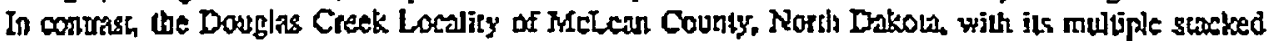

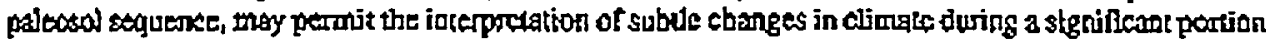
of the Holoosene.

The Dougles Creak section, exposed on the notih shore of Lake Sulinkawes. Consists of 15 butied A. horizons. Texwral and biogenic diftcrences batween indjyidunt soll hotizons $\Omega$ tuis locality are being uged to neveal smalt-scale environmenul change5. The combined nesuls of texiuesl, mdiocarban, strble

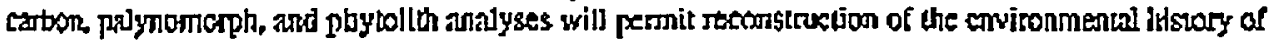
the section.

Than Dastias Cresk lowition is in a shallow valky fill that cxends eask-west a distante of $51.5 \mathrm{~m}$ The Holocene section is up to $4 \mathrm{~m}$ bick. The beried soils consist of 15 set5 of $A$ and $C$ botzons. Figure

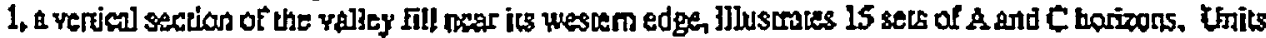
$J$ and 2 are modern $A$ and $C$ borizons, respectively. The odd-nombered units from 3 vo 31 ane Ab

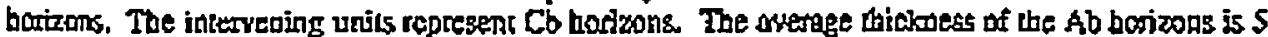
tm, wib i range of 2 to $34 \mathrm{~cm}$. The Co boizons are genecally thicher than the Ab horizonts, avtraging $10 \mathrm{~cm}$ and maging from $31032 \mathrm{~cm}$. Each Ab horizan is characterized by humus, lignīte fragmenus, and

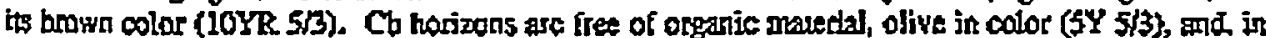
mary cases, have ribbons of catonare. The grain size of the Ab torizons consise of clay ranging from

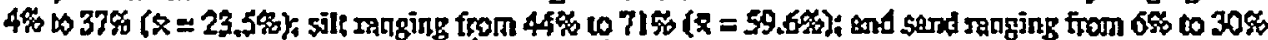

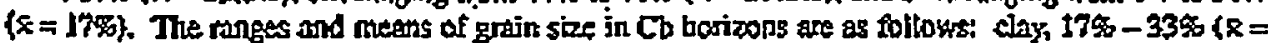

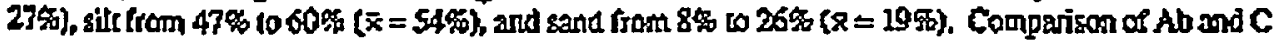

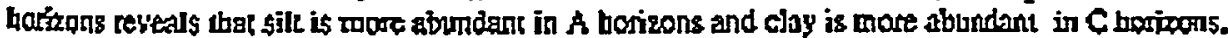

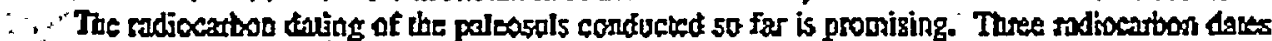
buve been obrained. Bone stmples from Units 7 ard 11 werc cinced al $2090 \pm 520$ years ard $3510 \pm 295$ years. respectivtly. Charcoal from Unif 17 was dated al 3800 years \pm 45 years. Bono collectod from

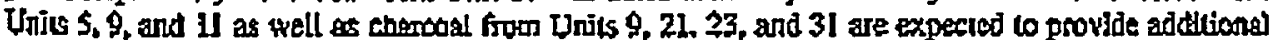
dales. Distinguishing berween charcoal and Palecxene fienite defess bas been grobienatic. Fourier (rensform inlrayed analysis (FI-IR) of samples proved incfiocive. Best gesules wete oblained using Iuminescent pecrograpbic analysts.

Preliminury 8'C values sange from -19.59 to $-23.69(\bar{x}=-22.25)$. These values indicare thet $C$, regctalion dominated the landzcire during formation of mast of the palfosals, Balues from - 19.39 so

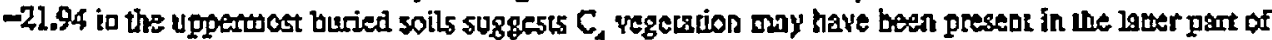

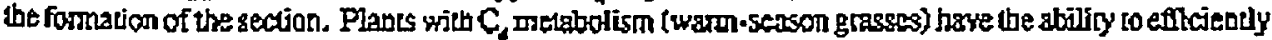

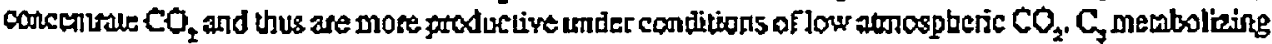
regetation (trex inost sbrubs, and cool-seneson grasses) fix $\mathrm{O}_{2}$ at the expense of $\mathrm{CO}_{2}$ under condicions of

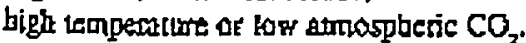

Compilation of the cutreal rosults leads to the hypothesis bat be potstace of the Is Ab horizons is

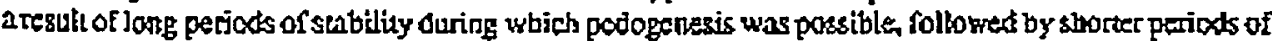
instabilicy. These changes can be explained by small-scale clinare changes at the sile. The forhoomint

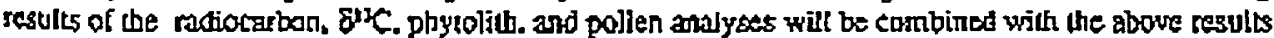
to test this hypothesis and interpred the scale of climate fluctuacions.

1) Moida. X. and Thompson, M.L. (Toga) Geol, Sos, Amer. Bul, 105, pp 1445-1451.

Figure 1

Douglas Greek Sectlor

Miter Unlt

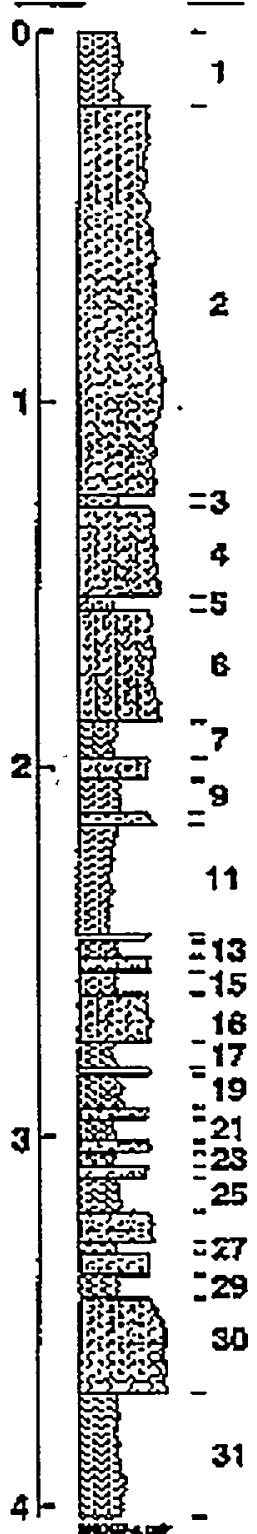

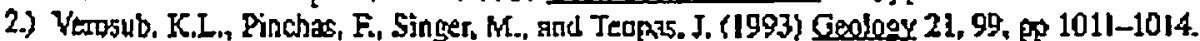

35 Kuebn, D.D. (1995) Pb.D. Disseralion, Texas A\&lM Liniv.

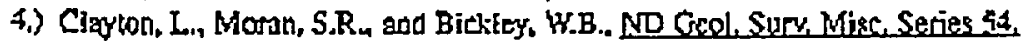




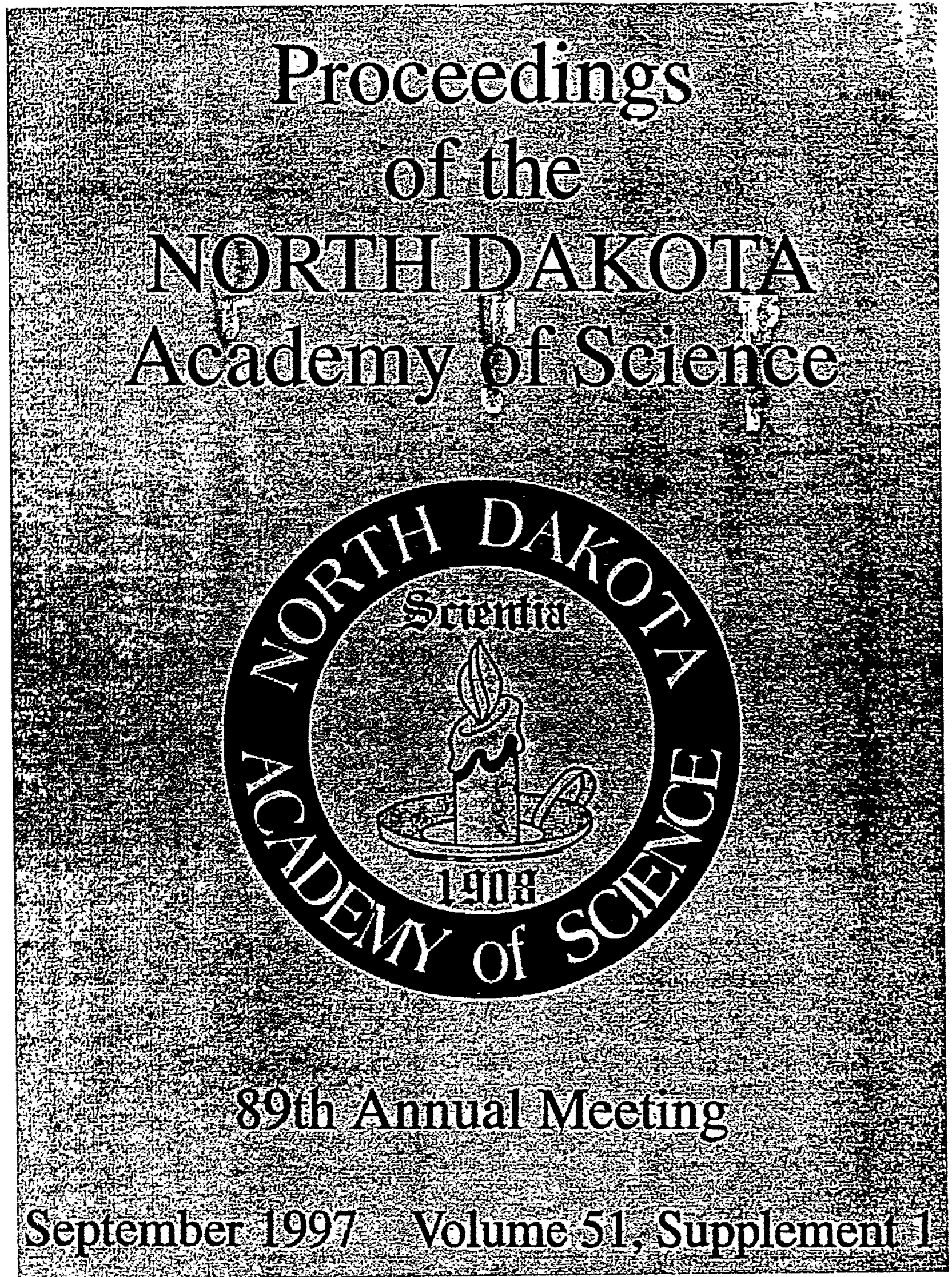

